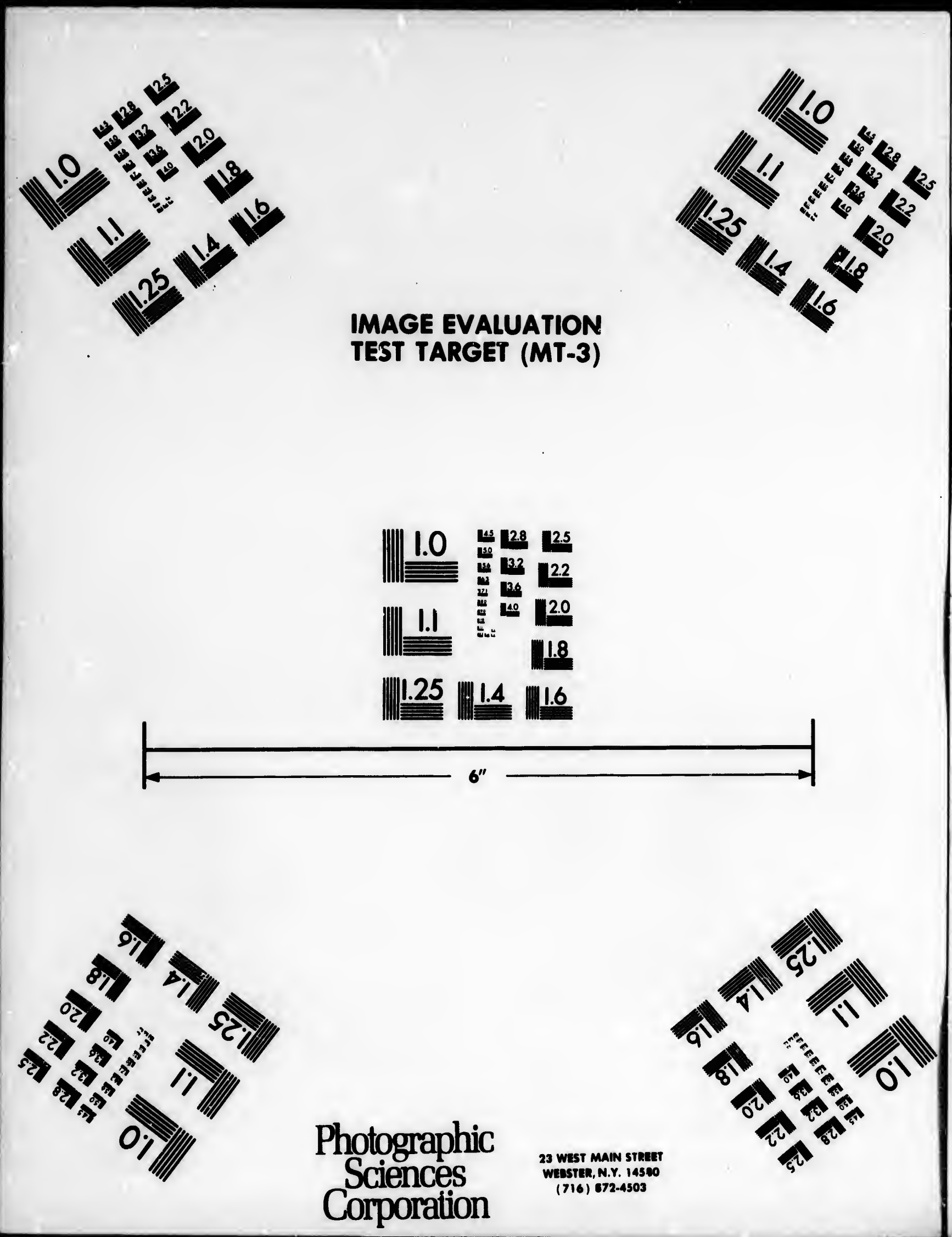




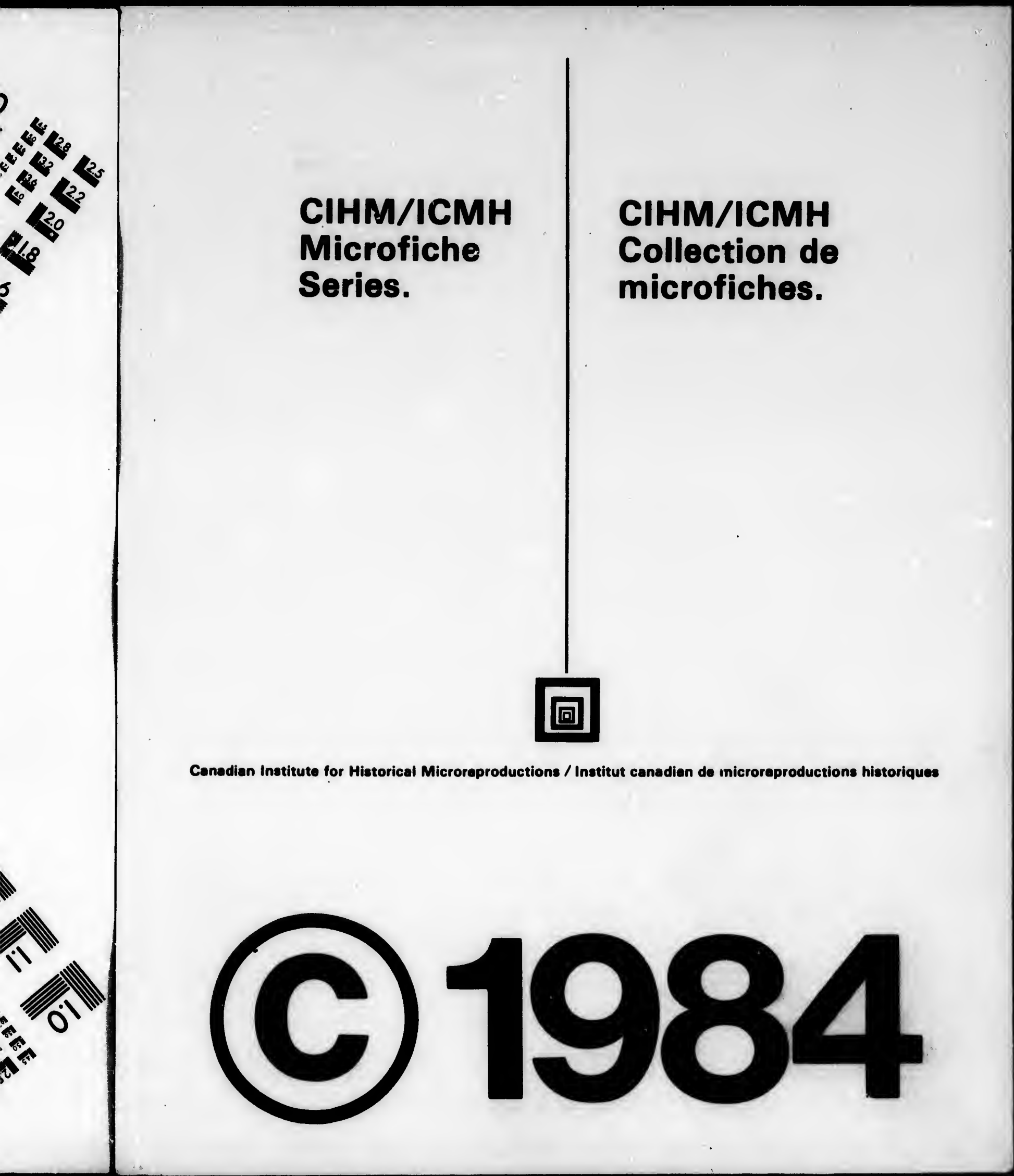


The Institute has attompted to obtain the best original copy available for fflming. Foatures of this copy which may be bibliographically unique. which may alter any of the images in the reproduction, or which may significantly change the usual mothod of filming, are checked bolow.

Coloured covers/

Couverture de coulour

Covers damaged/

Couverture endommagee

Covers restored and/or laminated/

Couverture restaurce ot/ou pelliculbe

Cover titlo misaing/

Le titre de couverture manque

Coloured maps/

Cortes gbographiques en couleur

Coloured ink (i.e. other than blue or black)/

Encre de couleur (i.e. autre que bloue ou noire)

Coloured plates and/or illustrations/

Planches et/ou illuatrations en coulour

Bound with other material/

Relis avec d'autres documents

Tight binuling may cause shadows or distortion along interior margin/

La re liure serré peut causer de l'ombre ou de la distortion la long de la marge intórioure

Blank leaves added during reatoration may appear within the text. Whanover possible, these have been omitted from filming/

II se peut que certaines pages blanches ajoutbes lors d'ure restauration apparaissent dans le texte. mais, lorsque cela stait possible, ces pages n'ont pas éte filmces.

Additional comments:/

Commentaires supplómentaires:
L'Institut a microfilme lo maillour exemplaire qu'il lui a sté possible de se procurer. Les dótails de cet exemplaire qul sont peut-stre uniques du point de vue bibliogrephique, qui peuvent modifler une image reproduite, ou qui peuvent exiger une modifleation dens la mothode normale de filmage sont indiques ci-doseous.

Coloured pages/

Pagee de couleur

Pages damaged/

Pages endommages

Pages restored and/or laminated/

Peges restaurbes at/ou pelliculbes

Pages discoloured, stained or foxed/

Pages décolorbes, techetés ou piqudes

Pages dotached/

Pages dotachóes

Showthrough/

Trensparence

Quality of print varies/

Qualies insgale de l'impression

Includes supplementary matorial/

Comprend du metórial supplémentaire

Only edition available/

Soula Sdition disponible

Pages wholly or partially obscured by errata slips, tissues, etc., have been refilmed to ensure the best possible image/ Lee pagea totalement ou partiellement obscurcies per un feuillot d'errata, une polure. otc., ont bté filmbes do nouveau de façon obtenir la meilleure image possible.
The 1 to th

The 1

poes of th filmi

Origl begl the 1 slon, othe firat sion, or III

The 1 chall TINL whic

Map diffo entir begil right requ mott

This item is filmed at the reduction ratio checked below/ Ce document est flimó au taux de róduction indiquó ci-dessous.

$10 x$

$14 x$

$18 x$

$22 x$

$23 x$

\begin{tabular}{rl|l|l|l|l|l|l|l|l|l|l|l|l|l|l|l|l|l|l|}
\hline \\
\hline
\end{tabular}


The copy fllmed hore has been reproduced thanks to the generodty of:

$$
\begin{aligned}
& \text { Dougles Library } \\
& \text { Queon's Unlversity }
\end{aligned}
$$

The imagee eppearing here are the beot quallty poeslble conoldering the condition and logiblitty of the orlginal copy and in keoping with the filming contract epeolfications.

Original coples in printed paper covere are filmed beginning with the front cover and ending on the last page with a printed or lllustrated impreslon, or the back cover whon eppropriate. All other orlginel coples are filmed beginning on the first page with o printed or lliuotrated impresalon, and ending on the last pege with a printed or lliluatrated impreasion.

The lact recorded frame on each microflche chall contain the aymbol $\rightarrow$ Imeaning "CONTINUED"), or the eymbol $\nabla$ (meaning "END"). whichover applies.

Maps, plates, charts, otc., may be fllmod at difforent reduction ratios. Those too lerge to be entiroly included in one exposure are fllmed boginning in the upper loft hand cornor. loft to right and top to bottom, as many fremes as required. The following dlagrame illuetrate the mothod:
L'oxemplaire films fut reprodult ordes o la óncroosits do:

\section{Dougles Library \\ Quean's Univaroity}

Les Images sulvantes ont sto reprodultes avec lo plus grand coin, compte tonu do la condition ot de la nottots do l'exemplaire filmb. ot on conformits avec les conditions du contrat do filmogo.

Les exemplaires originaux dont la couverture on papier eat imprimes cont filmcs on commonçant par lo premior plat et on terminant coit par la dornibre page qul comporte uno empreinte d'impression ou d'illuotration, solt par lo second plat, colon lo cas. Tous les autres exemplalres origlnaux sont fllmbe en commençant par la premíre page qul comporto une emprointe d'impreseion ou d'illustration ot en terminant par la dernilore page qui comporte une telle empralnte.

Un des symboles culvante apparaitra sur la derniore image de chaque microfiche, selon lo cas: lo symbole $\rightarrow$ signifie "A SUIVRE", lo symbole $\nabla$ signifie "FIN".

Les cartes, planches, tableaux, etc.. peuvent être filmbs des taux de róduction difforents. Lorsque le document eat trop grand pour etre reprodult on un soul cllchb. II eet films a partir de l'angle eupśrieur gauche, de gauche droite, ot de haut en bas, en prenant le nombre d'Images nócessaire. Les dlagrammes sulvants llluatront la mothode.
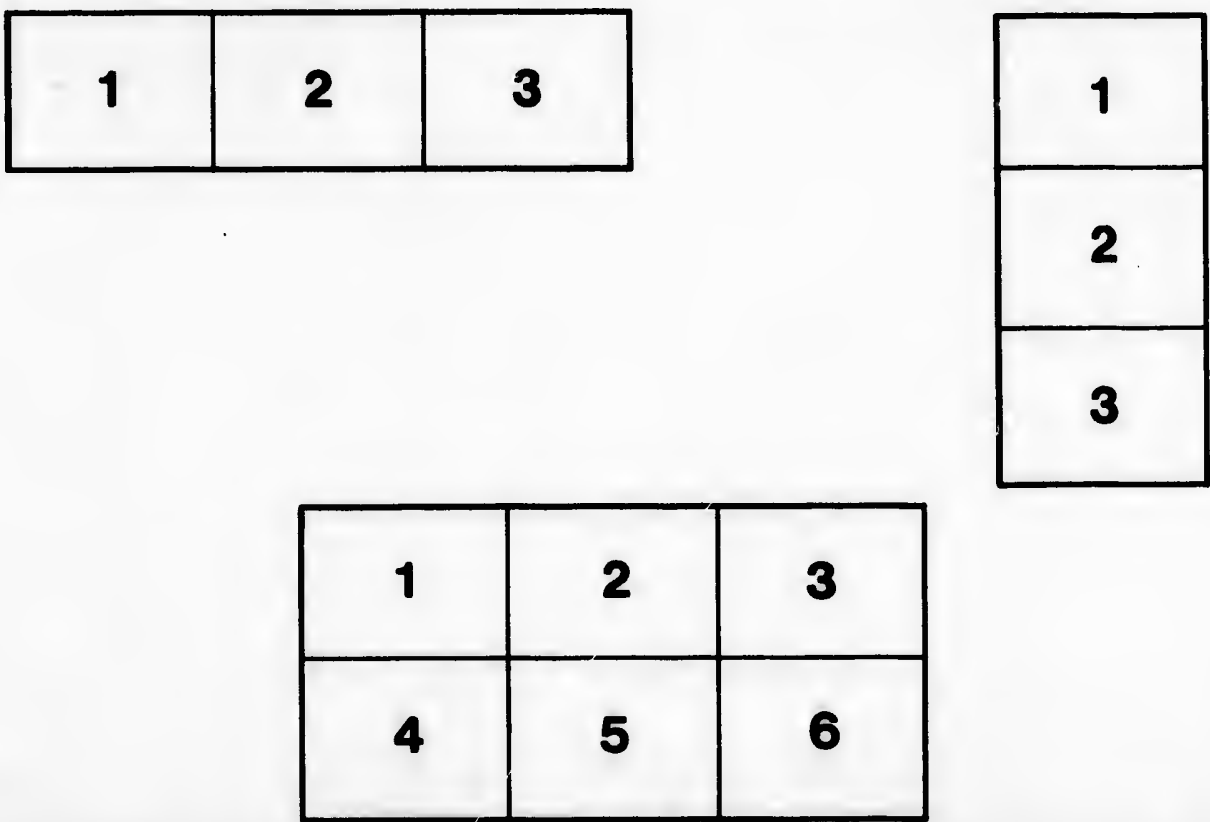
(4)

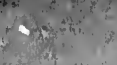

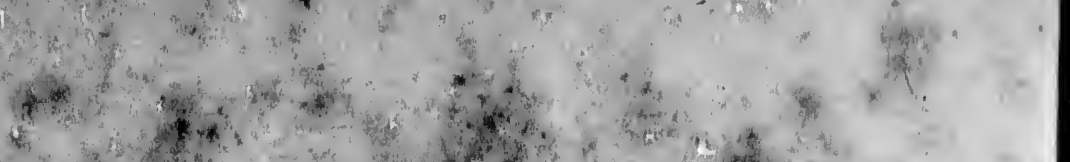

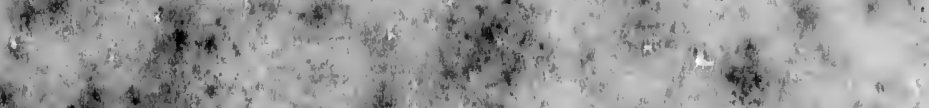

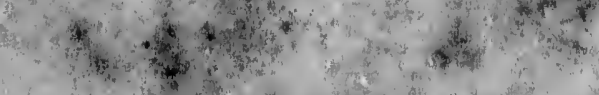

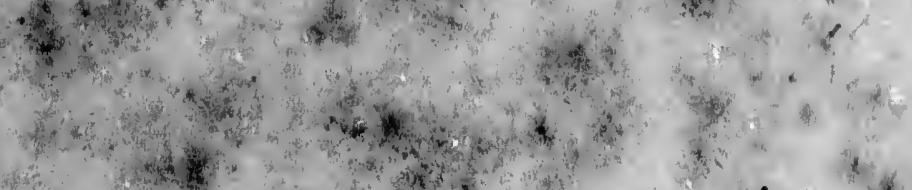

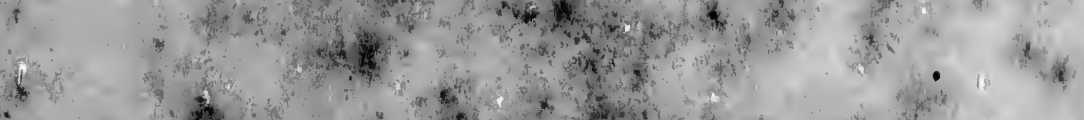

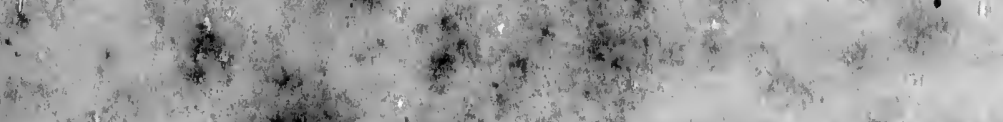

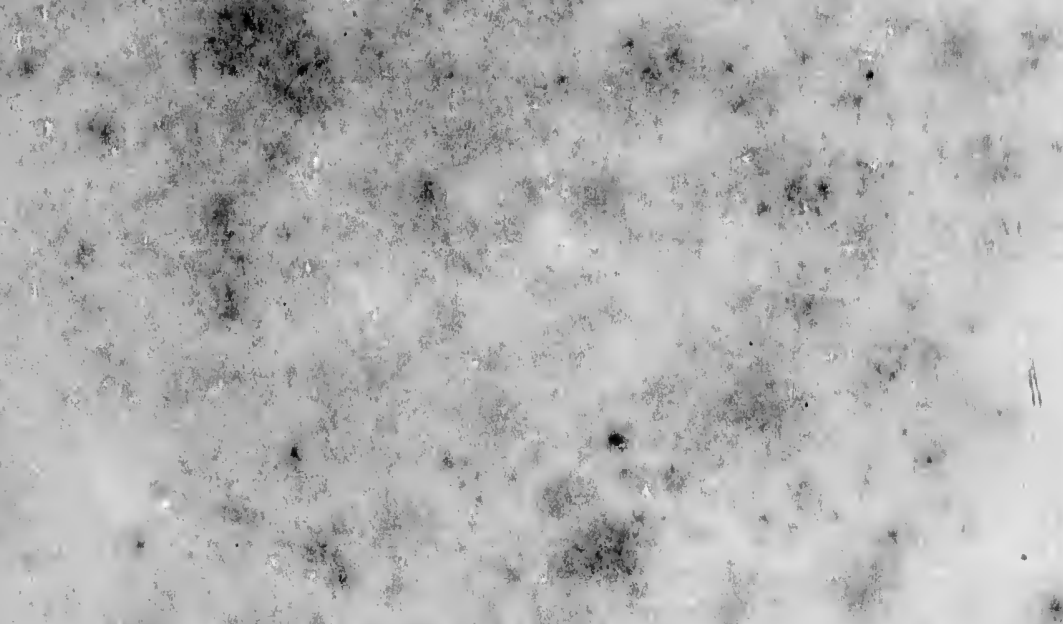

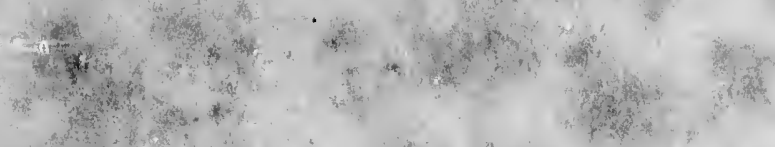

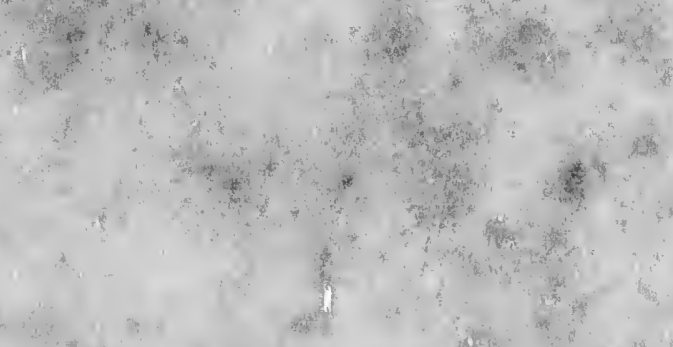

$\therefore$

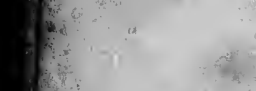

I.

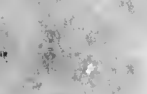

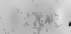


THE

NORTH AMERICAN $S Y L V A$. 


\section{UNITED STATES:}

Sold by Whus and Lirux, Coart Street, Boston; H. Howe, Now-Reven; J. Esktswan, Now York; T. Doneon and Sor, Philadelphin; Coske and Mhxwhu, Balsimore; Hort, Charleston, s. C.

LONDUN : BLLDwix, Cuanocx end Jor, Pacemonter Row; Durav and Co., Soho Square; Taxortar and Woata, Soho Squore.

PARIS : The Autroz, Place Saint-Michel, To: 8; Tacutrel and Wuats, rue de Bourbon, No. 2 ; Gakionami, rue Virienne. 


\section{THE \\ NORTH AMERICAN \\ $S Y L V A$, \\ o n}

\section{A DESCRIPTION OF THE FOREST TREES}

\section{O F T H $\mathrm{E}$}

UNITED STATES, CANADA AND NOVA SCOTIA,

Considered particularly with respect to their use in the Arts, and their introduction into Commerce;

TO WHICB IS $\triangle D D E D$

A DEschiption OF THE MOST USEFUL OF THE EUDOPEAT FOAEST TREES.

ILLUSAATED I5 COLOUAED ENGALVINGS.

Translated from the French of

F. ANDREW MICHAUX,

Member of the American Philosophical Society of Philadelphia; Correopondent of the Inatitote of France; Member of the Agricultural Societies of Charleston, S. C. Philadelphia and Masachuselts; Hooorary Member of the Historical, Literary and Philosophical Societien of Ner York.

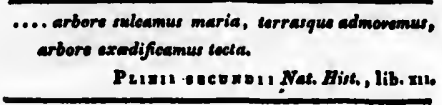

VOL. I.

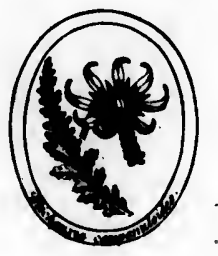

PARIS,

PRINTED BY C. D'HA UTEL.

мимимихихихихи

1819. 
$L^{P}$

$$
\text { QKH81. MS13 } 1819 \text { V.1 }
$$




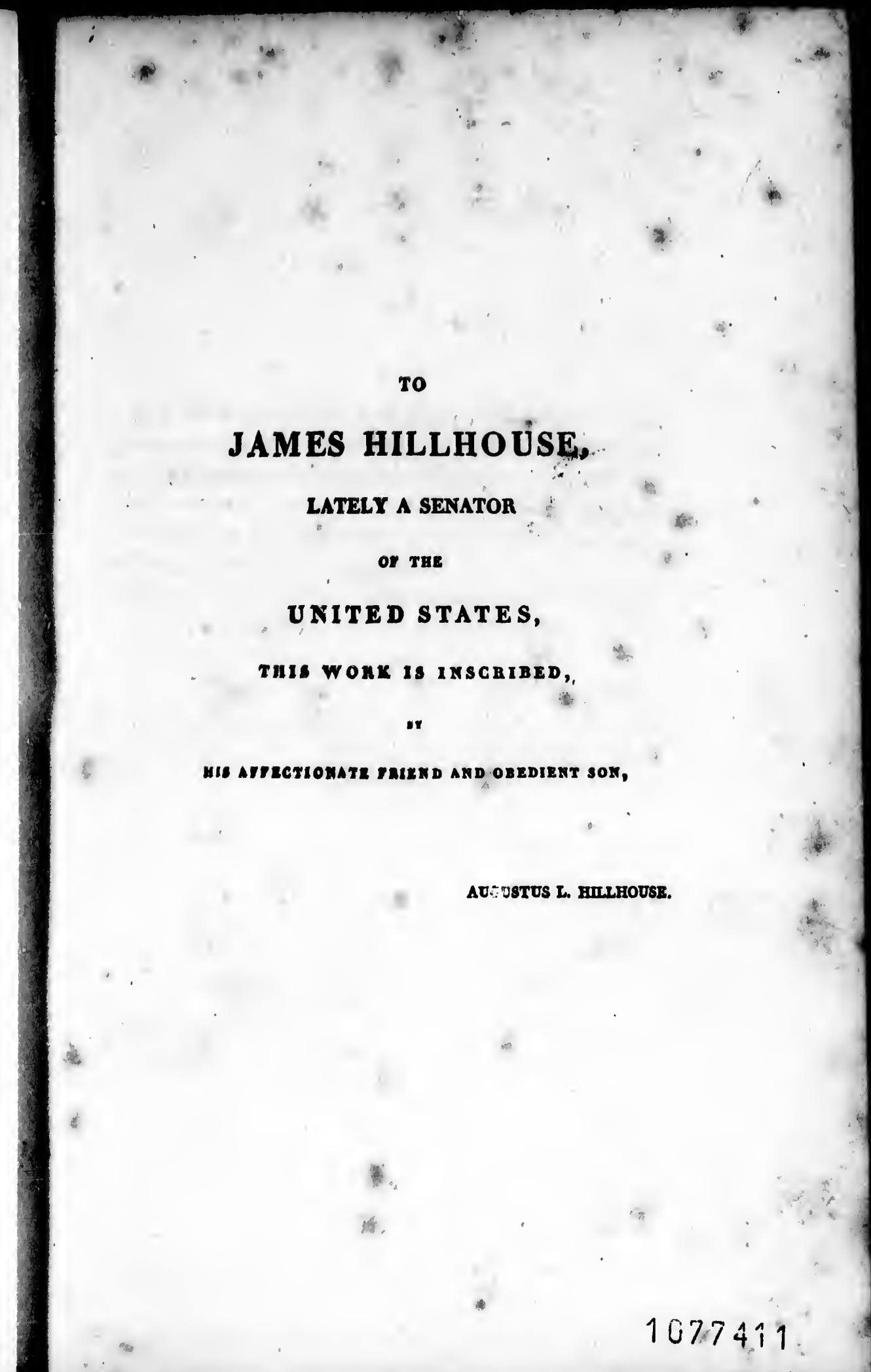




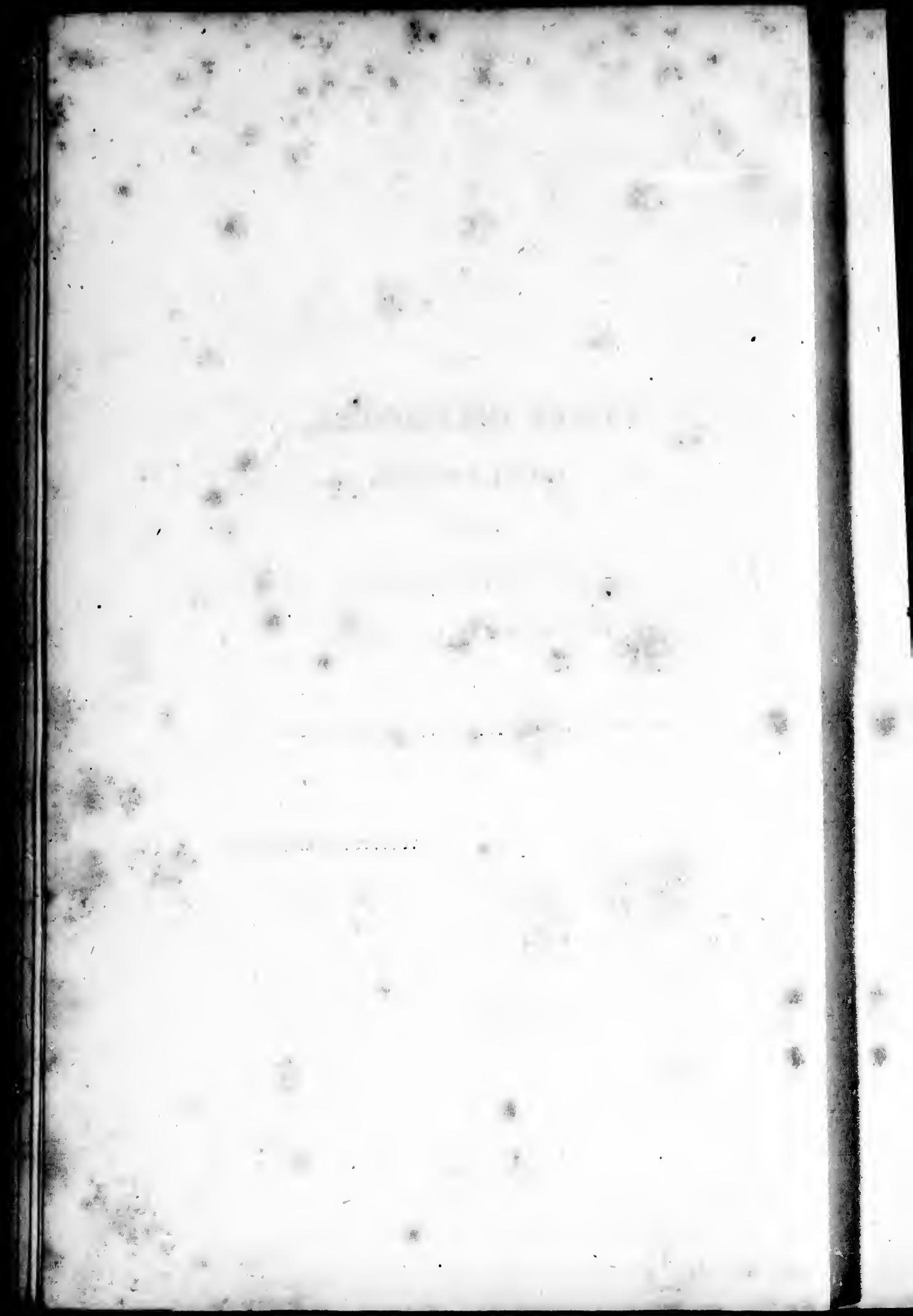


N. B. The Englich edition of the North American Sylva was announced in aix numbers. As it has been judged useful to add a few figures and descriptions to those at firt proposed, it is hoped the subscribers will not be diopleaced that a different division has been adopted; it was otherwice imposible to increase the number of plates, as the lowest price had been fixed upon the work.

Believing that it would be more agreeable to the reader to have the text of an uniform composition, the first number has been reprinted and is delivered w complement to the seventh.

F. A. MICHAUX. 


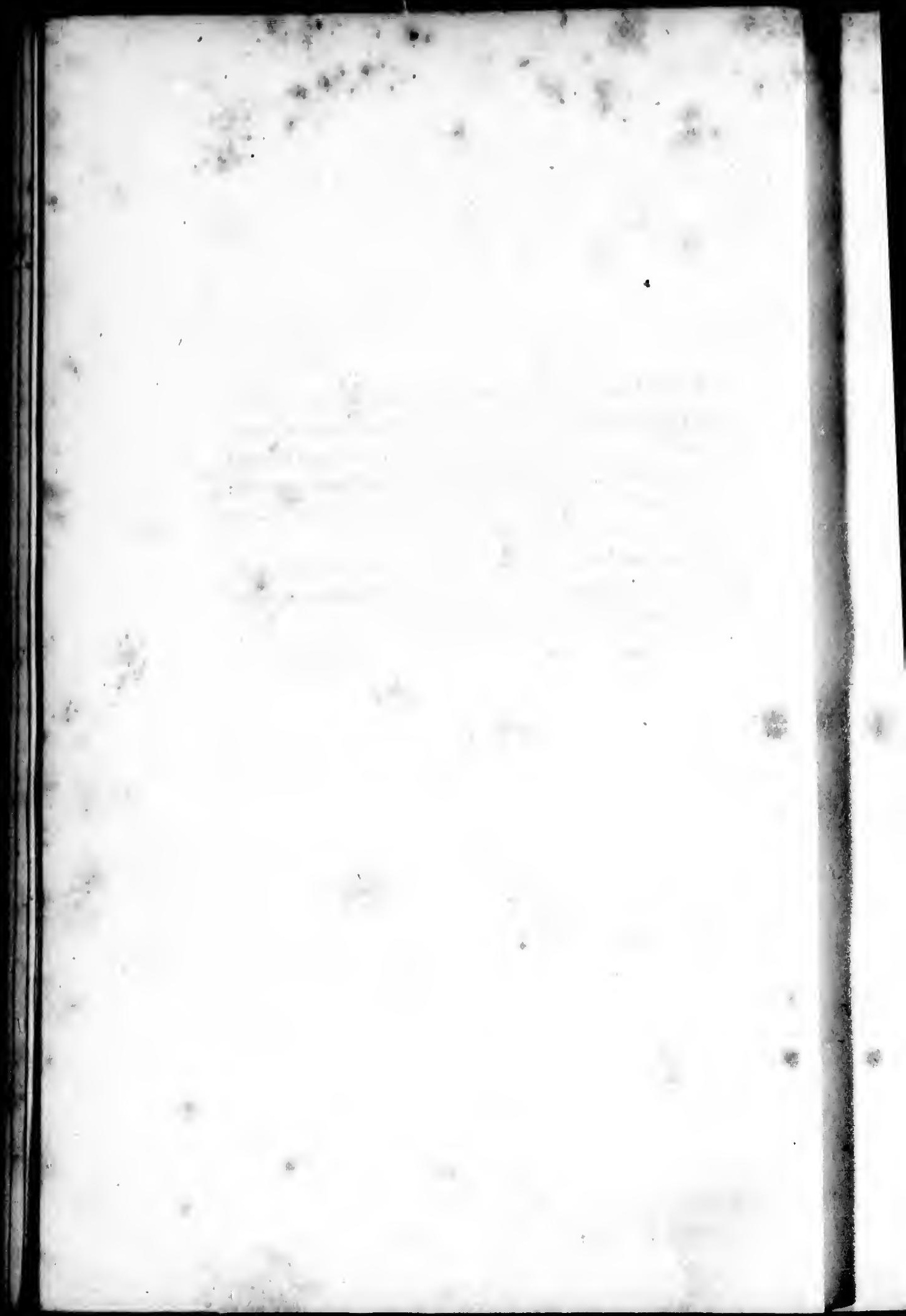




\section{P R E.F A C E.}

Tra Author of the North American Sylua has made me the most grateful return in his power, for the pains I have bestowed upon his publication, by requesting me to dedicate it to my father.

No literary pretensions, I am sensible, can be founded on a labour imperfectly executed, and 10 humble in its kind, that perfection itself would be without praisc. I should not bave attached my name to the part which I first translated, nor to the work thus entire, but for the pleasure which I was assured it would afford a revered parent, to whom my obligations exceed the common measure of filial gratitude. In the performance of so extended a task he will discern proofs of that perseverance which is the pasis of every valuable character; and in the usefulness of the work, an apology for my diversion from more appropriate pursuits.

The departures that may be observed from the sense of the original are in compliance with notes of the author : with more leisure I could have rendered my style less faulty. I have not escaped the use of impure idioms, which I was studions to avoid. American writers should labour assiduously to weed from their dialect all the pe- 
culiarities which are unauthorized by taste - not from deference to the critics, but to the laws of criticism: Our language, in its purity, is copious and flexible enough to be always susceptible of accuracy and grace.

The author of this valuable work will, I hope, be induced to complete it by a practical treatise on the formation and management of forests. That branch of economy, which is admirably developed in France and Germany, must soon command attention in the United States. Though three fourths of our soil are still veiled from the eye of day by primeval forests, the best materials for building are nearly exhausted : with all the projected improvements in our internal navigation, whence shall we procure supplies of timber, fifty years hence, for the continuance of our marine? The most urgent motives call imperiously upon the government to provide a seasonable remedy for the evil : from a government like ours, which is the faithful expression of the public will, and which has no concern but the prosperity and honour of the nation, prospective wisdom is reasonably demanded.

I have no pecuniary interest in this publication, and may therefore express my solicitude for its success. $\mathrm{Mr}$. Michaux-actuated no doubt by a mixed motive-desirous of rendering his name familiar to a people whom he respects, and anxious to possess them of a body of in- 
P R PPACE.

formation which he justly considers as of great practical utility, has executed this edition at an expense which ill comports with the modest fortune of a man of letters. It would not become us to accept such a present from an individual. While we allow Education among ourselves to loiter in the porch of Science, and consent to receive from strangers that knowledge of our own country which they should receive from us - for our repulation - let us, at least, reward their'services.

Besides his personal merit, the Author of the Syloa has hereditary claims upon our gratitude.

\author{
A. L. $\mathbf{H}$.
}

Citizen of the United States.

Paris, 20 May, 18ı.

govern$n$ of the prospersdom is

$n$, and ess. Mr. -desirhom he of in- 


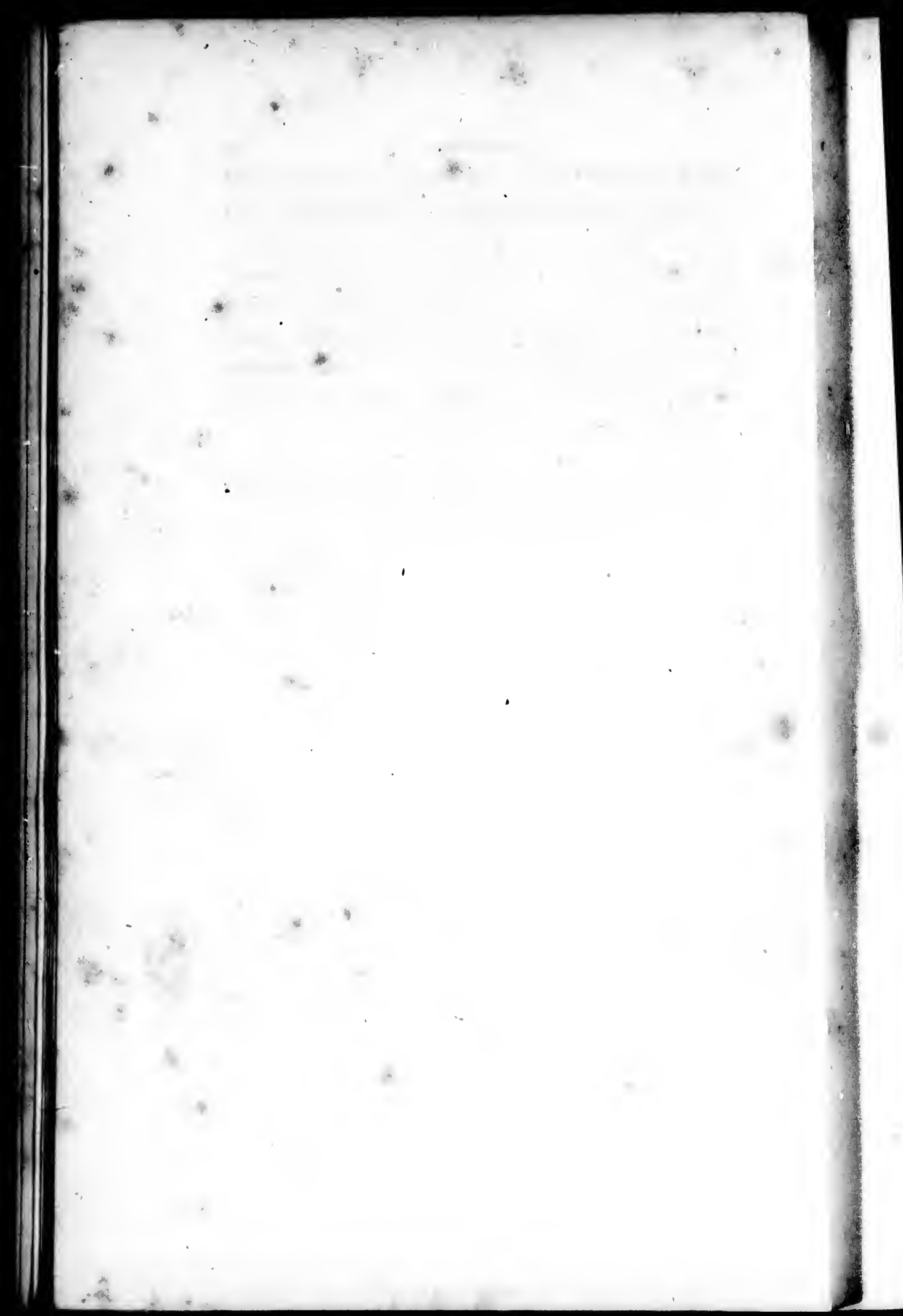




\section{INTRODUCTION.}

Tyz researches of learned botanists for more than a century past have shown how highly the North American Continent is favoured in its vegetable kingdom. But their object seems to have been rather the progress of botanical knowledge, and the embellishment of European gardens, than an acquaintance with the properties of the American plants and with the uses of the forest trees. This, on the contrary, was the end which I had particularly in view in my travels in the United States in 1807; and the work which I offer to the public is the fruit of my inquiries.

Before entering into any details concerning the plan which I have adopted, it should be remarked that the species of large trees are much more numerous in North America than in Europe : in the United States there are more than 140 species that exceed 30 feet in height, all which $I$ have examined and described; in France there are but 30 that attain this size, of which 18 enter into the composition of the forests, and 7 only are employed in building.

I. 
To collect information, it was necessary for me to visit different parts of the United States. Beginning at the District of Maine, where the winter is as long and as rigorous as in Sweden though 10 degrees farther south, I travelled over all the Atlantic States, in some of which the heat during six months is nearly as great as in the West Indies. Besides a journey of 1800 miles from north-east to south-west, I made five excursions into the interior parts of the country; the first, along the rivers Kennebeck and Sandy, passing through Hallowel, Winslow, Norridgewock and Farmington; the second, from Boston to Lake Champlain, crossing the States of New Hampshire and Vermont; the third, from New York to the Lakes Ontario and Erie; the fourth, from Philadelphia to the borders of the rivers Mononghabela, Alleghany and Ohio; and the fifth, from Charleston to the sources of the Savannah and Oconee. In travelling along the sea-coast, I visited the principal ports to examine the timber employed in ship-building, and entered work-shops of every description where wood is wrought. The knowledge of which I stood in need was principally in the possession of mechanics; accordingly, I consulted the most skilful workmen, natives of the 
for me country and Europeans, and by means of a series of questions previously prepared, collected, for the benefit of the United States as well as of Europe, a mass of information which I trust will be found in the main correct.

In proceeding southward, I noted exactly the disappearance of some species of trees and the appearance of others, according to the changes of climate or of soil.

I have pointed out the trees which form an object of commercial exchange between the Middle, Northern and Southern States, or are sent to the West Indies and to Great Britain; the parts of the country which produce them, and the ports from which they are exported; the different kinds of wood employed for fuel, for enclosing fields, and in the mechanical arts; the sorts of bark used in tanning, etc.

I have endeavoured, also, to impress on the American farmers the advantage of preserving and multiplying some species and of destroying others; for, in my opinion, a bad tree should not be suffered to exist where a good one might grow, and in no country is selection more necessary than in North America.

It may not be improper to observe that the Euro- 
peans have great advantages over the Americans in the management of woods. The principal forests are in the hands 0 : the governments, which watch over their preservation with a solicitude dictated by imperious necessity. Experience has amply demonstrated that no dependance can be placed, for the public service or the general supply, upon forests that are private property : falling sooner or later into the hands of persons eager to enjoy their price, they disappear and give place to tillage. In America, on the contrary, neither the federal government nor the several States have reserved forests. An alarming destruction of the trees proper for building has been the consequence - an evil which is increasing and which will continue to increase with the increase of population. The effect is already very sensibly felt in the large cities, where the complaint is every year becoming more serious, not only of the excessive dearness of fuel, but of the scarcity of timber. Even now, inferior wood is frequently substituted for the White Oak; and the Live Oak, so highly esteemed in ship-building, will soon become extinct upon the islands of Georgia.

Though the English language is almost universally spoken in the United States, yet their extent and 
ricans in orests are atch over d by imdemons, for the n forests or later eir price, America, nent nor a alarmding has creasing the indy very mplaint only of arcity of tly subOak, so become versally ent and their settlement at different periods have created a singular confusion in the nomenclature of trees : the same species has different names in different places, or even in the same district, and the same name is given to very different species. I have carefully collected these denominations, omitting such as are rarely employed.

I have described only those species which have been observed with attention by my father and myself. This remark is the more necessary, as the nurseries and gardens of Europe contain trees said to have come from North America, which neither he nor myself were fortunate enough to find. In several botanical works, also, trees are mentioned as species, which we discovered to be mere varieties. This last observation is particularly applicable to the Flora of North America, by Pursh, published in London in $18 \times 4$. Several Oaks, designated in it as species, I am confident will be found, on further examination to be varieties resulting from a difference of soil and climate. I have, however inserted extracts from such articles in that work as are not contained in my own. Allowances I hope will be made for the occasional freedom of my remarks upon botanical writers, who, from the want of per- 
sonal examination, have given erroneous accounts of the trees of North America, or unfavourable opinions of their timber : my object has been to lead to a more minute examination, and thus to an ultimate correction of error wherever it may be found.

At the close of the work will be placed a complete and particular recapitulation of the various kinds of wood used in different parts of the United States in the mechanical arts and for fuel, with a general index of the vulgar and scientific names.

In this first English edition important improvements have been made, particularly by inserting descriptions and drawings of several trees, such as the Yellow Wood of Tennessee and the Ohio Buckeye, of which I had not scen the flowers : of these species the seeds which I brought from the United States in 1803 have grown up and bloomed since the publication of my work. I have, besides, added descriptions and figures of the trees which principally compose the European forests and which are the most commonly employed in building, pointing out those which might be advantageously propagated in the United States. The Chesnut, the Beech and the Hornbeam are omitted, because their perfect re- 
semblance in aspect, foliage and fruit to the analogous American species rendered a separate figure unnecessary.

I flatter myself that the course I have pursued in the execution of this task will be found more practically useful, and consequently more generally interesting, than if 1 had followed a more scientific path. I have bcen anxious to render my work acceptable to the great body of American agriculturists, to the farmers of the Northern and the planters of the Southern States. It will afford me sincere gratification if I succeed in obtaining the approbation of the liberal and enlightened men by whom I was encouraged during my residence in the United States.

Public acknowledgments are due for the assistance which I received from Dr. H. Muhlemberg, one of the most learned botanists that America has produced, who deserved a distinguished place among the most eminent in that pleasing science in Europe; from Mr. W. Hamilion, an enlightened lover of the arts and sciences, who took pleasure in collecting, at his magnificent seat (the Woodlands) near Philadelphia, such vegetables of the United States and of other countrics as are useful in the arts or in medicine; and from Mr. W. Bartram, known equally 
for his travels and his various knowledge in natural history, and for the amiability of his character and the obliging readiness with which he communicates to others the result of his researches.

To the pupils of the late professor B. S. Barton, professor D. Hosack and Dr. Bigelow, animated like their masters with an ardent desire for the advance: ment of Natural History, I leave the task of completing my work, and of offering to their fellowcitizens a treatise on this interesting subject more worthy of their acceptance. 


\section{THE \\ NORTH AMERICAN

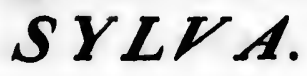

\section{OAKS.}

Ir the greater part of North America, as well as in Europe, there is no tree so generally useful as the Oak. It is every-where the most highly. esteemed in the construction of houses and of vessels, and is commonly selected for implements of husbandry. It seems, also, to have been multiplied in proportion to its utility : without insisting upon the diversity of climates to which it is indigenous, we may observe that the number of its known specics is already considerable and is daily increasing, particularly on the Western Continent, and that its varieties are infinite. These considerations determined my futher, in 1801 , after his return from the United States, to publish a Treatise containing drawings and descriptions of the Oaks of that country, which was favourably received by the lovers of botany and agriculture.

The following extract from his work exhibits a just outline of this tree: "The genus of the Oaks (Introduct. 
p. 4.) comprises many unknown species; most of those which grow in America exhibit such various forms while young, that they can be ascertained with certainty only when arrived at maturer years. Often an intermediate variety so nearly resembles two species, that it is difficult to determine, from the foliage, to which of them it helongs. Some species are so variable, that it is impossible, by the leaves, to recognize their identity in youth and at a more advanced age. Others are so similar, that specilic characters must be derived from the fructification, which is itself liable to variations and exceptions. It is only by a comparison of stocks of different ages that analogous species can be distinguished, and varieties correctly referred to their species.

“I have endeavoured to arrange the American Oaks in a natural series, the characters of which I tirst sought in the fructification : but this afforded only unimportant distinctions, such as the position of the barren flowers, whether pedunculated or nearly sessile, and the size and period of the fruit. Neither was I able to found my distinctions on the structure of the cup : I was obliged, therefore, to have recourse to the foliage, which has been made the basis of a division into two sections, the first containing the species with beardless leaves, and the second, those in which the summit or lobes are terminated by a bristle.

“ The interval between the appearance of the flower and the maturity of the fruit is different in different 
st of those ous forms h certainty an interies, that it which of that it is identity in so similar, the fructiind excepd different hed, and

ican Oaks rst sought important Alowers, the size to found : I was foliage, into two beardless mmit or

e flower different species; and this distinction I have admilted as a secondary character.

"All the Oaks are proved to be monacious. We know too that on the European White Oak and other species, the female flowers are situated above the male upon the shoots of the same seavon; Iliat both are axillary; and that, immediately after the fecundation, the male flowers fade and fall, while the female blossom continues advancing through the natural slages, till, in the course of the year, it ripens into perfect truit. But there are some species whose furtile flowers remain stationary a whole year, and begin to develope their germ the second spring, probably because they are not fecundated the first season; so that eighteen months elapse between the appearance of the flower and the maturity of the fruit. Hence I have formed a subdivision into species of annual and species of biennial fructification. The female flower which is axillary the first season, ceases to be so of course at the falling of the leaf. Several species are found upon the Old Continent whose fructification is biennial, such as the Cork Oak, Quercus suber, etc."

I have derived great assistance from my father's work, and have adopted his arrangement, which perfectly accords with my own observations. But I have inserted several new species, and have suppresacd two that were not well ascertained : the existence of one of them is doubtful, and the other is evidently a duplicule. 
What chiefly distinguishes my work from his, is the more extended practical observations; which are the fruit of my own researches. My constant aim was to appreciate the utility of each species in the mechanical arts, and to point out those which are the most deserving of attention in Europe and America. If in th: respect I have some advantage, my father's work will always preserve its title to the attention of botanists and amateurs of foreign plants, by other details not consistent with my plan. They will find, for example, quotations from all the authors who had previously taken notice of the species he describes, and in the plates, leaves of the young plant as well as of the full-grown tree.

I have described twenty-six American species, which I have divided into two sections, according to the term of fructification : the first comprising ten species that bear fruit every year; and the second, sixteen of which the Iructification is biennial. I have learned by multiplied observations that, with the exception of the Live Oak, the wood of the first section is of a finer texture, more compact, and consequently more durable.

Linnaus, in, the third edition of his Species Plantanum, published in 1774 , described fourteen species of Oak; of which five only are natives of the New World. Since that period such additions have been made to the list, that the new edition of Willdenow's Species Plantarum published in 1805 , contains forty-four 
OAXS.

his, is the ch are the I was to apmechanical ost deservin th:s deork will altanists and Is not connple, quoJusly taken the plates, full-grown ies, which o the term pecies that n of which multiplied Live Oak, ure, more

Plantanum, s of Oak, w World. made to 's Species irty - four
Américan species; of which sixteen were recognized by Messrs. Humboldt and Bonpland in Old Mexico, and twenty-six by my father and myself in the United States and the adjacent countries. Probably the American series will be still farther augmented by discoveries in the western part of Louisiana, and in the interior provinces of New Spain, a country 1200 miles in extent lying between the United States and Old Mexico, which no naturalist has explored.

In America, as we have just observed, are found forty-four species, which are all comprised between the 2oth and the 48th degrees of north latitude; in the Old Continent are enumerated only thirty, which ire scattered on both sides of the equator, beginning at the Goth degree north.

This sketch is not without utility, and appears naturally in this place; such parallels might perhaps contribute more than is generally thought to the progress of botany and agriculture, and they deserve particular attention from naturalists travelling in foreign countries. It would be interesting to possess comparative tables of those plants which are found in the higher latitudes of both Continents, and of the trees and shrubs of the temperate climates of America with the analogous species found in nearly the same latitude in Asia. I have long entertained a wish, which will doubtless be shared by all who interest themselves in the science, that botanists would go more deeply into the geography of 
14

OAXs.

plants. The rapid progress of the young Americans who are beginning to devote themselves with ardour to the study of Natural History, will soon afford the requisite information concerning their own portion of the globe. 
ricans who dour to the re requisite f the globe.

\title{
METHODICAL DISPOSITION OF THE OAKS
}

\section{OF NORTH AMERICA;}

INCIUDING TEREE EUROPEAN SPECIES.

\author{
Monucia polyandria. Lins. Amentaca. Juss. \\ FIRST DIVISION. \\ Fructification annual. \\ FIRST SECTION. - Leaves lobed.
}

I. White Oak. ..... Quercus alba.

2. Common European Oak Quercus robur.

3. European White Oak. . Quercus robur pedunculata.

4. Mossy-cup Oak. . . Quercus olivaeformis.

5. Over-cup White Oak. . Quercus macrocarpa:

6. Post Oak. . . . . Quercus obtusiloba.

7. Over-cup Oak. . . Q Quercus lyrata.

$$
\text { SECOND SECTION. - Leaves toothed. }
$$

8. Swamp White Oak. . . Quercus prinus discolor.

9. Chesnut White Oak. - Quercus prinus palustris.

10. Rock Chesnut Oak. . Quercus prinus monticola.

11. Yellow Oak. . . . Quercus prinus acuminata.

22. Small Chesnut Oak. . Q Quercus prinus chincapin. SECOND DIVISION.

Fructification biennial; leaves mucronated. (except in the 13 th species.) FIRST SECTION. - Leaves obtuse or entire:

13. Live Oak. . . . . Quencus virens. 
Methodical disposition, etc.

14. Cork Oak. . . . . Quercus suber.

15. Willow Oak. . . . . Quercus phellos.

16. Laurel Oak. . . . . Quercus imbricaria.

17. Upland Willow Oak. . Quercus cinerea.

18. Running Oak. .... Quercus pumila. SECOND SECTION. - Leaves lobed.

19. Bartram Oak. ... Quercus heterophylla.

20. Water Oak. . . . Quercus aquatica.

21. Black Jack Oak. . . . Quercus ferruginea.

22. Bear Oak. . . . . Quercus bunisteri. THIRD SECTION. - Leaves mullifid or many-clefted.

23. Barren Scrub Oak. - Q Quercis catesbari. 24. Spanish Oak. . . . Quercus falcata. 25. Black Oak. . . . . Quercus tinctoria. 26. Scarlet Oak. . . . Quercus coccinea: 27. Grey Oak. .. . . . Quercus ambigua. 28. Pin Oak. . . . . Quercus palustris. 2y. Red Oak. ..... Quercus rubra. 



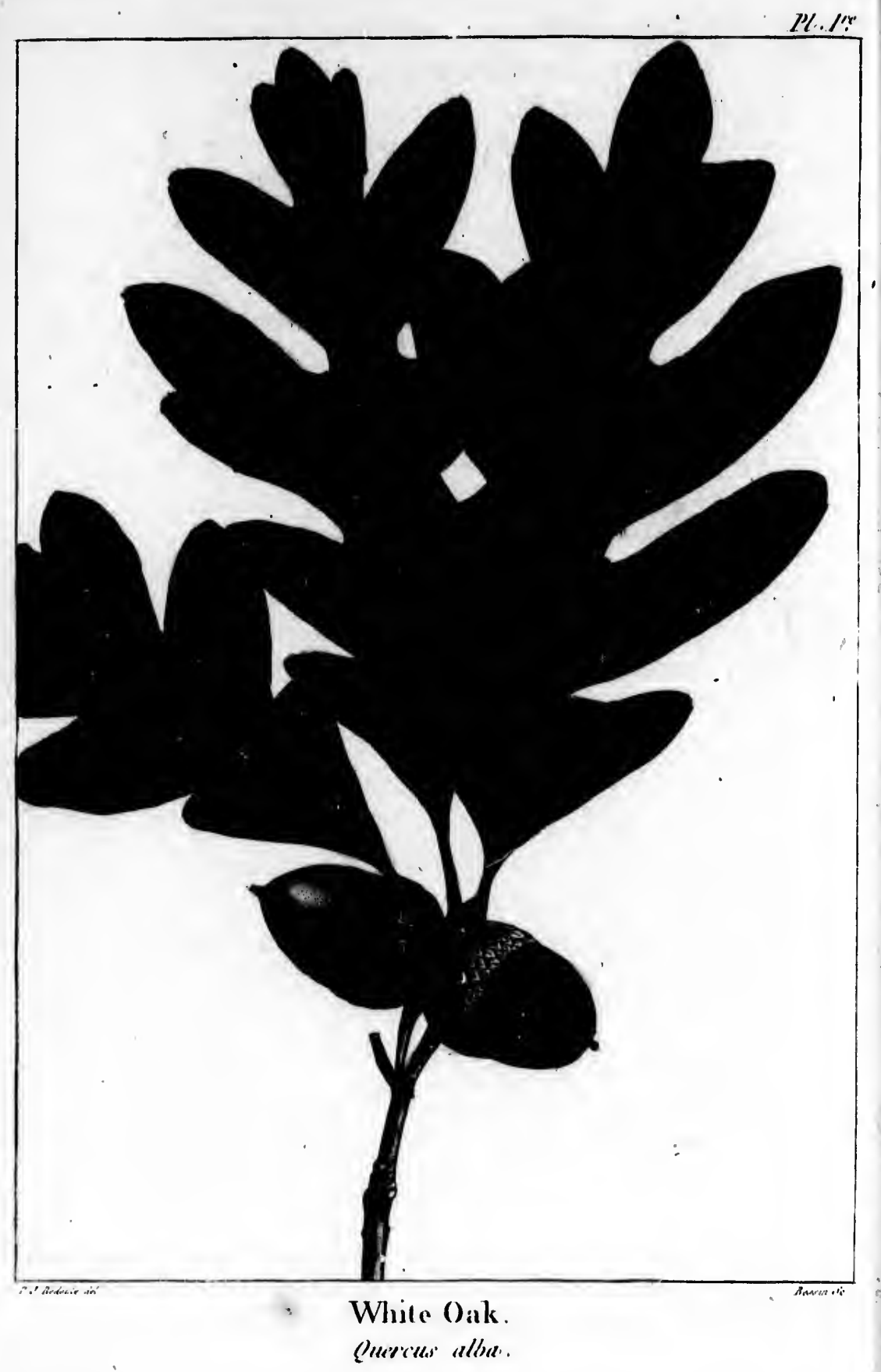




\section{WHITE OAK.}

Qunncos ALBA. Q. foliis subaequaliter pinnatifidis; laciniis oblongis, obtusis, plerumque integerrimis; fructu majusculo; cupuld craterata, tuberculoso-scabratd ; glande ovata.

Throvgrout the United States and in Canada, this tree is known by the name of White Oak. The environs of the small town of Trois Rivières in Canada, latitude $46^{\circ} 30^{\prime}$, and the lower part of the river Kennebeck in the District of Maine, are the most northern points at which it was observed by my father and myself. Thence we traced it along the sea-shore to a distance beyond cape Canaveral, latitude $28^{\circ}$, and westward from the Ocean to the Country of the Illinois, an extent of more than 1200 miles from north-east to south-west, and nearly as much from east to west. It is; lowever, by no means equally diffused over this vast tract ; in the District of Maine, Vermont and Lower Canada, it is little multiplied, and its vegetation is repressed by the severity of the winter. In the lower part of the Southern States, in the Floridas and Lower Louisiana, it is found only on the borders of the swamps with a few other trees which likewise shun a dry and barren soil : this region is generally so sandy that it is covered with a continued growth

s. 
of Pines, as will be more particularly mentioned in the description of the Iong-leaved Pinc. The White Oak is observed also to be uncommon on lands of extraordinary fertility, like those of 'Tennessec, Kentucky and Gennessee, and of all the spacious vallies watered by the western rivers. I have travelled whole days in those States without secing a single slock, though the few that exist, both there and in the Southern States, exhibit the most luxuriant vegetalion.

The White Oak abounds chiefly in the Middle Slates and in Virginia, particularly in that part of Pennsylvania and Virginia which lies between the Alleghanies and the Ohio, a distance of about 150 miles, beginning at Brownsville on the Mononghahela. Near Greensburgh, Maconelville, Unionville and Washington Court-house, I have seen large forests, nine tenths of which consisted of White Oaks whose healthful appearance evinced the favourable nature of the soil, though in general they were not more than 15 inches in diameter. East of the mountains this tree is found in every exposure, and in every soil which is not extremely dry or subject to long inundations; but the largest stocks grow in humid places. In the western districts, where it composes entire forests, the face of the country is undulated, and the yellow soil, consisting partly of clay with a mixture of calcarious stones, yields abundant crops of wheat.

By the foregoing observations it appears that the severity of the climate, the fertility of 'he soil, its dryness 
sntioned in The White ands of ex, Kentucky ies watered ole days in though the iern Slates,

iddle States ennsylvania ies and the $\zeta$ at Browns1, Maconeluse, I have onsisted of iced the fa1 they were the mound in every o long innid places. sses entire , and the mixture of theat. at the seis dryness or humidity, are the causes which render the White Oak so rare over three quarters of the United States that it is inadequate to supply the local demand, though the country does not contain a fourth of the population which it is capable of supporting.

Among the American Oaks this species bears the greatest analogy to the Furopean Oak, especially to the variety called European White Oak, Quercus pedunculuta, which it resembles in foliage and in the qualities of its wood. The American White Oak is 70 or 80 feet high, and 6 or 7 fect in diameter ; but its proportions vary with the soil and climate. The leaves are regularly and obliquely divided into oblong, rounded lobes, destitute of points : the sections appeared to be the deepest in the most humid soils. Soon after their unfolding they are reddish above and white and downy beneath; when fully grown they are smooth and of a light green on the upper surface, and glaucous underneath. In the fall they change to a bright violet colour, and form an agreeable conirast with the surrounding foliage which has not yat suffered by the frost.

This is the only Oak on which a few of the dried leaves persist till the circulation is renewed in the spring. By this peculiarity and by the whiteness of the bark, from which it derives its name, it is easily distinguished in the winter. The acorns are of an oval form, large, very sweet, contained in rough, shallow, greyish cups, and borne singly or in pairs, by peduncles 8 or 10 lines in 
length, attached, as in all the species with annual fructification, to the shoots of the season.

The fruit of the White Oak is rarely abundant, and frequently for several years in succession a few handfuls of acorns conld hardly be collected in a large forest where the tree is multiplied. Some stocks produce acorns of a deep blue colour; but $I$ have found only two individuals of this variety, one a flourishing tree in the garden of Mr. W. Hamilton near Philadelphia, and the other in Virginia.

The trunk is clad in a white bark, which is often variegated with large black spots. On stocks less than 16 inches in diameter the epidermis is divided into squares ; on old trees, growing in moist grounds, it is in the form of plates laterally attached. The wood is reddish, and very similar to that of the European Oak, though lighter and less compact, as may be proved by splitting billets of each of the sime size : in the American species the vessels which occupy the intervals of the concentrical circles are visibly less replete. But of all the American Oaks which I shall describe, this is the best and the most generally used, being strong, durable, and of large dimensions. It is less employed than formerly in building only because it is scarcer and more costly.

At Philadelphia, Baltimore, and in the smaller towns of the Middle States, the frame of all well built houses, whether of brick or wood, is of White Oak. West of the Alleghanies, where Pine boards are not easily procured, 
the White Oak is substituted for the floors and for the exterior covering of the frame, notwithstanding its liability to warp and split.

It is much used in the construction of mills and dams, particularly for such parts as are exposed to be alternately wet and dry.

The wooden bridge nearly 3000 feet long that unites Boston and Cambridge, is supported by posts of White Oak, from 16 to 20 feet in length, which have replaced those of White Pine on which it originally stood.

The excellent properties of this wood cause it to be preferred for a great variety of uses, among which are many articles manufactured by the wheel-wright. This trade is carried to the greatest perfection at Philadelphia, and its wares are highly esteemed for solidity both at home and abroad. White Oak perfectly seasoned is employed for the frame of coaches, waggons and sledges, for the mould board of ploughs, the teeth of wooden harrows, the fellocs and spokes of wheels, particularly the spokes of coach-whecls. In the Northern, Middle and Western States, the naves are also made of Oak in the country; but it splits too easily to be proper for this object. Except in the District of Maine, it is always chosen for the bow or circular back of windsorcliairs. The wood of the young stocks is very elastic and is susceptible of minutc division, hence it is preferred for the large baskets used in harvesting, for the hoop of sieves, the bottom of riddles, and the handles of coach-

into squa d is reddish, Oak, though d by splitting rican species he concentrihe American and the most of large di$y$ in building

naller towns built houses, West of the ly procured, 
whips which are braided and covered with leather; at Boston it is chpsen for pail-handles, and in Maine, for axe-helves.

In many parts of the Middle States, the White Oak is selected for the posts of rural fence, and beyond Laurel-Hill in Pennsylvania, where it is common, it forms the entire enclosure.

The bark is considered by many tanners as the best for preparing leather for saddles and other similar objects ; it is little employed however, because in the United States the bark of the trunk and large limbs only is employed; and on these the cellular integument is much thinner in the White than in the Red Oak, which is besides more abundant.

I have been told that the bark yields a purple dye : though I have not witnessed the fact, I am disposed to believe in its existence, as I received the information from persons residing several hundred miles from each other. But if the colour was not defective in permanence or intensity, it would have found its way into commerce, like the Quercitron of the Black Oak.

Of all the species that grow east of the Mississippi, the White Oak alone furnishes staves proper for containing wine and spirituous liquors. The domestic consumption for this purpose is immense, and vast quantities are exported to the West Indies, Great Britain, and the Islands of Madeira and Teneriffe. The Post Oak might indeed be applied to the same use, but even in Mary- 
leather; at Maine, for

White Oak and beyond common, it

as the best r similar obause in the ce limbs only tegument is Oak, which

purple dye : disposed to information s from each $=$ in permats way into pak.

sissippi, the containing onsumption antities are $n$, and the Oak might $n$ in Mary- land and Virginia, where it is moat common, it is not sufliciently multiplied to supply the local demand.

The Rock Chesnut Oak and the Swamp White Oak in the Northern and Middle States, the Chesunt White Oak and the Over-cup Oak in the South, are compact enough to prevent the escape of spivits and line oils, yet porous enough to absorb them. If they wnited every requisite quality, and were employed for this purpose, they would be consumed in less than ten yeurs.

It is well understood at Bordeaux that the: wood of the European White Oak is closer grained than that of the American species, and the preference is given to our domestic growth or to that imported from Dantzick. The American Oak is exclusively employed in Madeira and the West Indies only because it is cheapar and more easily procured.

White Oak staves are exported from all the ports of the Northern and Middle States, and from New Orleans. Those which come from Baltimore, Norfolk and New Orleans, are far superior to those of the Norlliern States : the difference results naturally from that of the suil and climate.

The quantity of Oak staves exported to England and the West Indies appears, by two oflicial documents that I have examined, to be considerable. In 1808 , the value received by England amounted to more than 146,000 dollars, and the number of staves sent to the West Indies exceeded 53 millions. I am un:able to fix the pro- 
24

WHITE OAK.

portion of the two species of White and of Red Oak; probably more of the first are sent to England, and of the second to the Colonies. The price of both has varied surprisingly within a hundred years : in 1720 , staves for barrels were sald at Philadelphia at $\mathbf{3}$ dollars a thousand; in 1798 , at 18 dollars; and in 1808 , at 3o dollars. In August 1807 , before the American Embargo, they were advertised at 55 dollars, and in April 1808, after that municipal regulation became known, at 100 dollars:

The young White Oak, on account of its elasticity, is very proper for hoops; but it has less strength and less durability than the Hickory.

Among the uses of this wood, the most imporlant is in ship-building. In all the dock-yards of the Northern and Middle States, except in the District of Maine, it is almost exclusively employed for the keel, and always for the lower part of the frame and the sides : it is preferred for the knees when sticks of a proper form can be found. In the smaller ports south of New York, the upper part of the frame is also of White Oak ; but such vessels are less esteemed than those constructed of more durable wood.

At Boston, the trunnels, or the pins by which the side-planks are attached to the ribs, are of this species.

To obtain correct notions on the comparative value of the American White Oak and the European Oak, I consulted French, English and American ship-wrights, in almost all the ports of the United Stales : they 
f Red Oak; land, and of th has varied o, staves for a thousand; o dollars. In 0 , they were 88 , after that o dollars.

its elasticily, strength and

important is the Northern f Maine, it is , and always des : it is preper form can w York, the ak ; but such nstructed of

by which the this species. parative value ppean Oak, I ship-wrights, Stales : they generally agreed that the European Oak was tougher and more durable from the superior closeness of its grain, but that the American species was more elastic and required a shorter time with only half the weight to bend it. This advantage, though important in shipbuilding, does not compensate for the openness of its pores. Experience, however, every day shows that by growing in places long inhabited its quality is improved; and if the American vessels are less durable than those built in Europe, it is because the timber is not thoroughly seasoned.

- The greater part of the immense, quantity of White Oak exported from the United States is sent to England. It is shipped only from the Northern and Middle Slates, in the form of boards and of square timber : what goes to England from Quebec is brought from the shores of Lake Champlain, for Canada probably furnishes hardly enough for its own consumption.

By an extract from the custom-house books of St. John, which I have already quoted, 143,00o cubic feet of Oak wood appear to have entered by this port during the first six months of 1807 . Oddy, in his Ireatise on the Commerce of Europe, says, that in the English dockyards the White Oak from British America is esteemed excellent timber. This opinion, simply considered, is correct; but that which comes from Baltimore and Philadelphia must still be superior.

Before I conclude this article, I must be allowed to I. 
hasard a conjecture on the consequences of the neglect of all means of preserving and multiplying this tree in the United States; consequences which neither the federal government nor the States have taken any measures to prevent. From the increase of population, and from the impoverishment of the soil produced by a gradual change in the climate, the White Oak will probably, in less than 50 years, be the most rare in the Middle States, where it is now the most abundant; and in Tennessee, Kentucky, Gennessee and farther north, where it is the least multiplied, it will be the most common, and will replace the species which now compose the forests, but which the soil will then be too feeble to sustain. Thus, near the river Kennebeck, in the midst of the primitive forests composed of the Beeches, the Canoe Birch, the Sugar Maple and the Henlock Spruce, I have observed small tracts, formerly cleared and since abandoned, which are naturally repeopled with the White and Grey Oaks; and in the lower part of Virginia, poor Red Oaks, Yellow Pines and Ioblolly Pines are extensively replacing trees of a better quality. East of the mountains, the vallies that lie along the rivers are, with a few exceptions, the only places where the Oak could be advantageously reared; but these fertile lands are more profitably devoted to husbandry.

The American White Oak cannot, in my opinion, be regarded as an useful acquisition to the foresis of Europe. Its elasticity, which renders the young stocks proper for 
hoops, is doubtless a valuable property; but the Chesnut of France is superior for this purpose, because it is more durable.

The White Oak is used in the royal dock-yards of England probably because it has been found impossible to procure supplies of European Oak. Perhaps it is employed only for the lower part of the frame, while the European Oak is reserved for the upper timbers.

If the advantage in this comparison be allowed to be on the side of the European species, the Americans should lose no time in introducing it into their forests. To corporations particularly, whose property is less frequently alienated, I take the liberty of addressing this advice, which, if followed, would be productive of great advantage to themselves and to the public. The analogy of the climates leaves no doubt of the perfect success of this tree in the United States, an example of which is found in the garden of Messrs. J. and W. Bartram, 3 miles from Philadelphia, where there is a large stock which has yielded seed for several years, and which continues to expand with vigour.

\section{PLATE I.}

A branch with leaves and acorns of the natural size. dry. opinion, be s of Europe. proper for 


\section{COMMON EUROPEAN OAK.}

Quercus Robur. Q. foliis petiolatis, oblongis, glabris, sinuatis; lobis rotundatis; fructibus oblongis, sessilibus.

To the particular attention bestowed upon this interesting tree in modern times is owing its division into two species, the Common European Oak, Quercus robur, and the European White Oak, Quercus pedunculata.

'These two species, which are much alike and are usually considered as the same, grow in the same countries, and frequently together. They constitute the greater part of the European forests, from the 6oth to the 35th degree of north latitude, overspreading a great part of the north of Asia and the northern extremity of Atrica. They are most abundantly multiplied on the shores of the Black Sea, in Germany, England, France and some parts of Italy, where the climate is particularly favourable to their growth.

The Common European Oak is from 60 to 80 feet in height, numerously ramified, and crowned with an ample and majestic summit. The bark upon the trunk is thick, and upon old stocks, deeply furiowed. The leaves are petiolated, smooth, and of an uniform colour on both sides, enlarged towards the summit, and very coarsely toothed. The acorns are oval and sessile, which is the principal difference between the two species. 
s, glabris, essilibus.

this interrision into ercus robur, culata.

$e$ and are ame countitute the the 6oth preading a rthern exmultiplied England, climate is oo feet in d witl an he trunk is The leaves colour on , and very ile, which ecies.

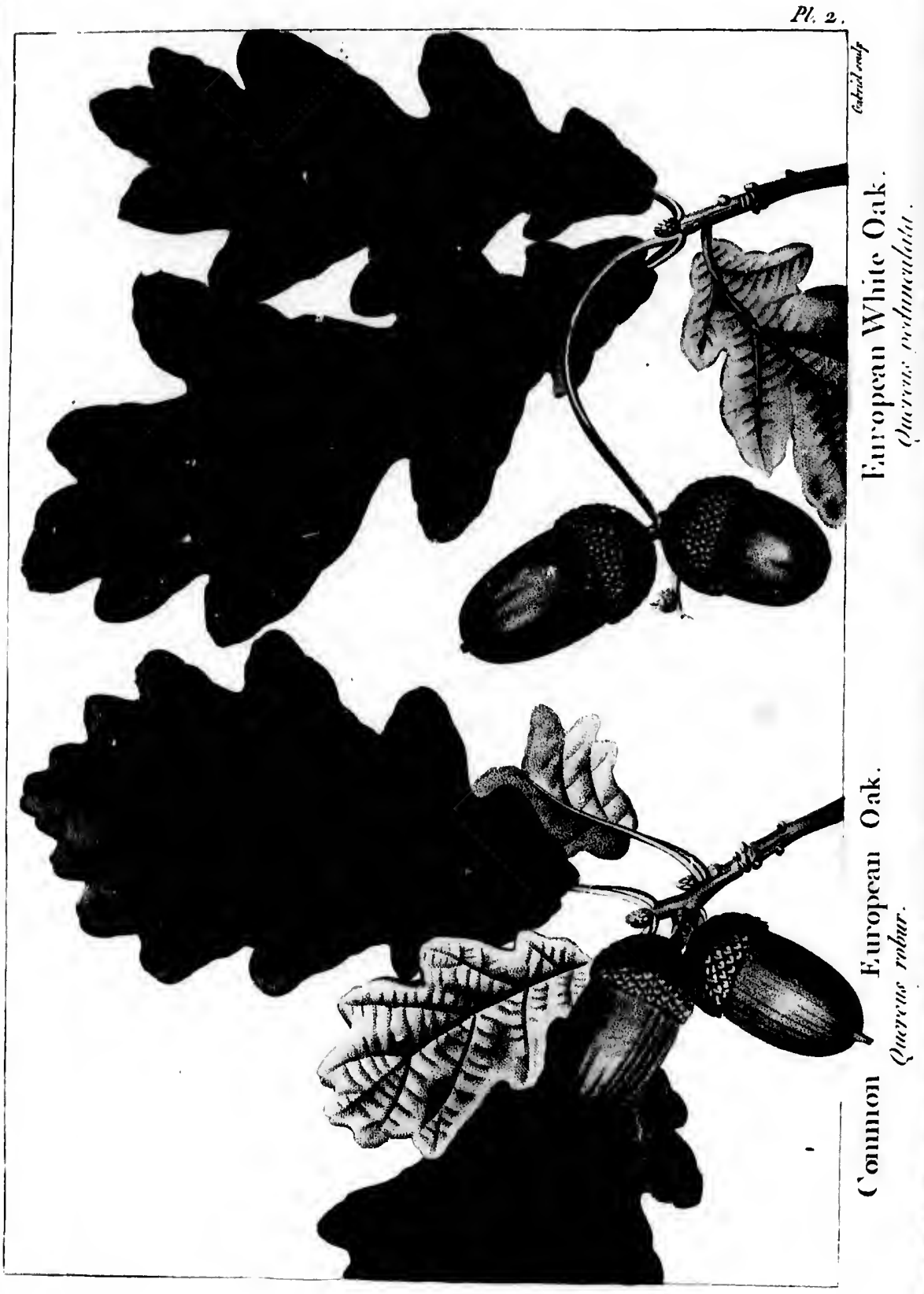




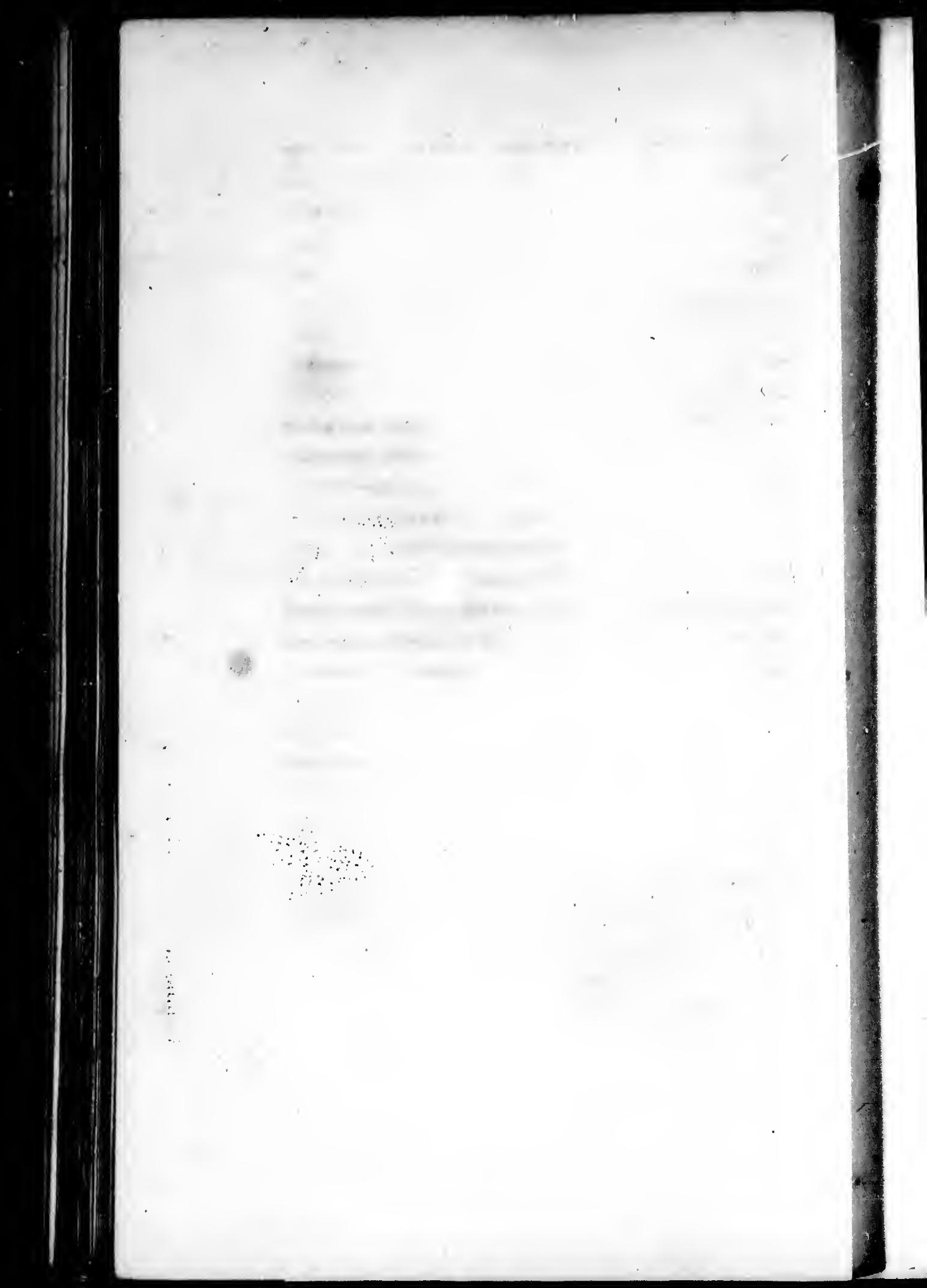


This tree prefers high places and the declivities of hills, with a barren gravelly soil ; hence it grows more slowly, and its wood is more compact, tougher and heavier than that of the European White Oak. It is less used for household stuff and other kinds of joinery, because it is less easily wrought; but is more esteemed for building and for works that require great strength and durability.

The Common European Oak is subdivided into many varieties, the most valuable of which are the European Black Oak, Quercus robur lanugnosa, and the Quercus robur glomerata. The first is only 30 or 40 feet high, with small, thick leaves, very downy underneath ; its timber is compact and excellent for fuel. The secon i never rises to a great height; the leaves are small, but smooth on both sides; the acorns are of an inferior size and collected in clusters upon a short common peduncle.

\section{PLATE II.}

A branch of the Common European Oak with lea is and acorns of the natural size. 


\section{EUROPEAN WHITE OAK.}

Quercus peduncurata. Q. foliis subsessilibus, glabris, sinuatis; fructibus oblongis, pedunculatis.

Tre European White Oak grows of choice in rich bottoms, where the soil is decp and moderately humid. It reaches the height of go or 100 feet, and has a large well proportioned trunk, which is often undivided for a considerable distance, and which spreads into a large commanding summit. The bark upon the body is very thick, and on old trees, deeply furrowed ; upon the limbs and the young stocks it is greyish, smonth and glossy. The leaves are of a light green on the upper surface, whitish beneath, widened towards the summit, deeply sinuated with blunted points, and supported by short petioles like those of the American White (lak. They are more or less divided according to the age of the tree and to the moisture of the soil. A part of the dry discoloured foliage persists through the winter and fulls the ensuing spring.

Besides the difference of the foliage, this species is constantly distinguished from the preceding by its fruit, which is supported singly or in pairs by slender peduncles 2, 3, or even 4 inches long. The acorns are of an oval shape, from 9 to 18 lines in length, according to the age and vigour of the tree, and contained in shal- 
low cups : they fall about a fortnight before those of the Common Oak.

The wood of the European White Oak is of the same colour with that of the American species, the sap being white and the heart reddish; but the texture is closer and the pores fuller, whicls is probably the reason of its bcing less elastic, but stronger and more durable. It is more generally esteemed than the Common Oak as it furnishes larger timber, splits more regularly, and is more easily wrought ; hence it is preferred for the construction of houses and ships, and is extensively employed by the joiner, the cartwright and the cooper.

Throughout Kurope, except in the north of Russia, the bark of the Common Oak and the White Oak is almost exclusively used in tanning. That which is taken from the branches and from small stocks is preferred, because the epidermis is thinner, and the cellular integument, which contains the tannin, more abundant.

Oak wood is more generally used in Europe than in the United States, where the different species of Ash, Birch, etc., in some measure supply its place. The European White Oak would be a valuable addition to the American forests, and $I$ have sent out acorns to begin the formation of nurseries.

species is its fruit, der pedare of an ording to $d$ in shal-

ce in rich scoloured e ensuing 


\section{MOSSY-GUP OAK.}

QuEncus ontveronmis. Q. foliis oblongis, glabris, suhtus glaucis, profunde incerfualiterque sinuato-lobatis; fruchu ovato; cupuld profundius crateratd, superne crinitd; glande olivaformi.

I BAvE observed this species of Oak only in the State of New York on the banks of the Hudson above Albany and in Gennessee, where it is so rare that it has bitherto received no specilic name.

Its leaves are of a light green above and whitish beneath : they resemble those of the White Oak in colour, but differ from them in form, being larger, and very deeply and irregularly laciniated, with rounded lobes so various in shape that it is impossible to find two leaves that are alike. The acorns are of an elongated oval form, and are enclosed in cups of nearly the same configur. ation, of which the scales are prominent and recurved, except near the edge, where they terminate in slender flexible filaments : from this peculiarity I have derived the name of Mossy-cup Oak.

This tree is 60 or 70 feet in height, with a spacious summit and an imposing aspect. The bark is white and laminated; but the tree is chiefly remarkable for the form and disposition of its secondary branches, which are slender, flexible, and always inclined towards the 
'abris, suhtus batis; fructu me crinild :

in the State n above Althat it has

whitish be$k$ in colour, r, and very ded lobes so 1 two leaves I oval form, ae configurd recurved, in slender ave derived a spacious is white and ble for the hes, which owards the

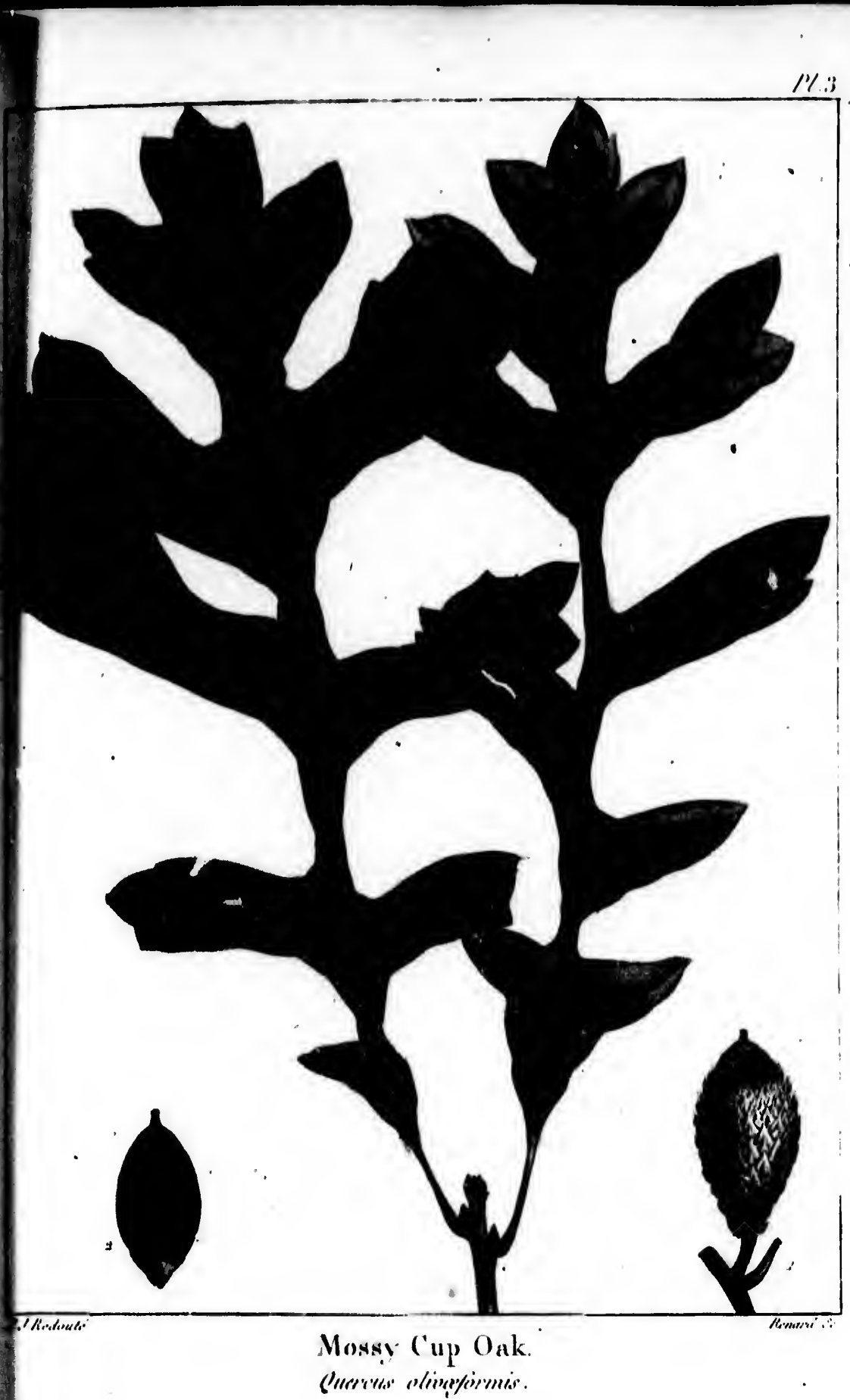




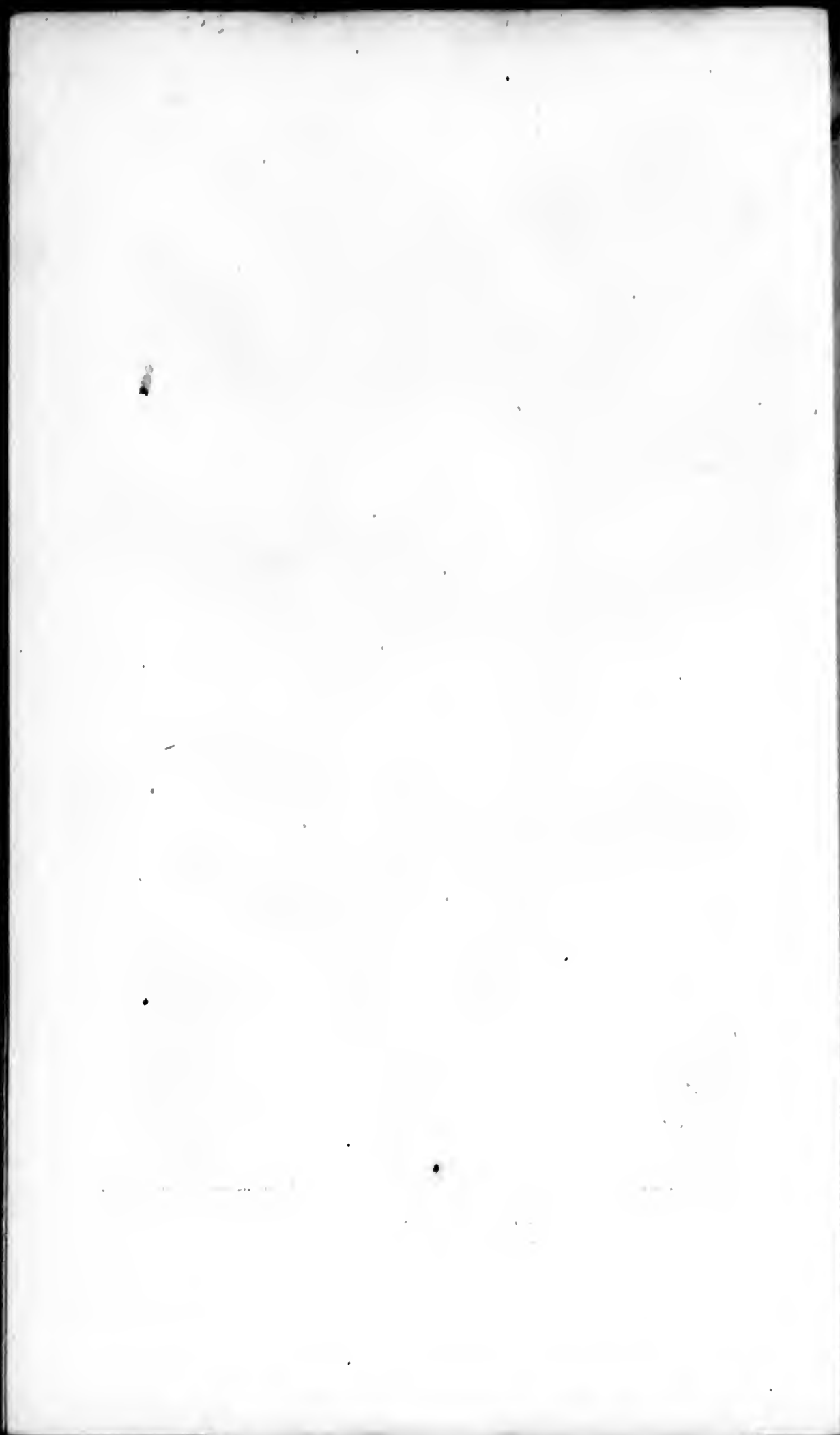


MOSSY-CUP OAR.

earth. This peculiarity alone would render it a valuable acquisition for parks and gardens.

As I have met with this species only in uninhabited places, I have had little opportunity of examining its wood; as far as I can judge, it is not better than that of the White Oak, though far superior to that of the Red Oak.

\section{PJATE III.}

Leaves of the natural size. Fig. 8 , An acom with the cup. Fig. 2, An acorn without the cup. 


\section{OVER-CUP WHITE OAK.}

Quercus macrocarpa. $Q$. foliis subtomentosis, profunde lyratimque sinuato-lobatis, obtusis; fructu naximo; cupula profundius craterata, superne crinatá; glande turgide ovata.

THIs interesting species is most multiplied beyond the Alleghanies, in the fertile districts of Kentucky and West Tennessee, and in Upper Ionisiana near the Missouri. It is called by the Americans Bur Oak and Over-cup White Oak, and by the French of Illinois, Chêne à gros gland.

It is a beautiful tree more than 60 feet in height, laden with dark tufted foliage. The leaves are larger than those of any other Oak in the United States, being frequently 15 inches long and 8 broad : they are notched near the summit, and deeply laciniated below. The acorns, which are also larger than those of any other American species, are oval and enclosed for two thirds of their length in a thick rugged cup, bordered with fine flexible filaments. Sometimes, however, in compact forests, or in very temperate seasons, the filaments do not appear, and the edge of the cup is smooth and bent inwards.

The fructification of this tree is not abundant, and as its wood is inferior to that of the White Oak, it is little esteemed in the United States. 
$1 \% 4$

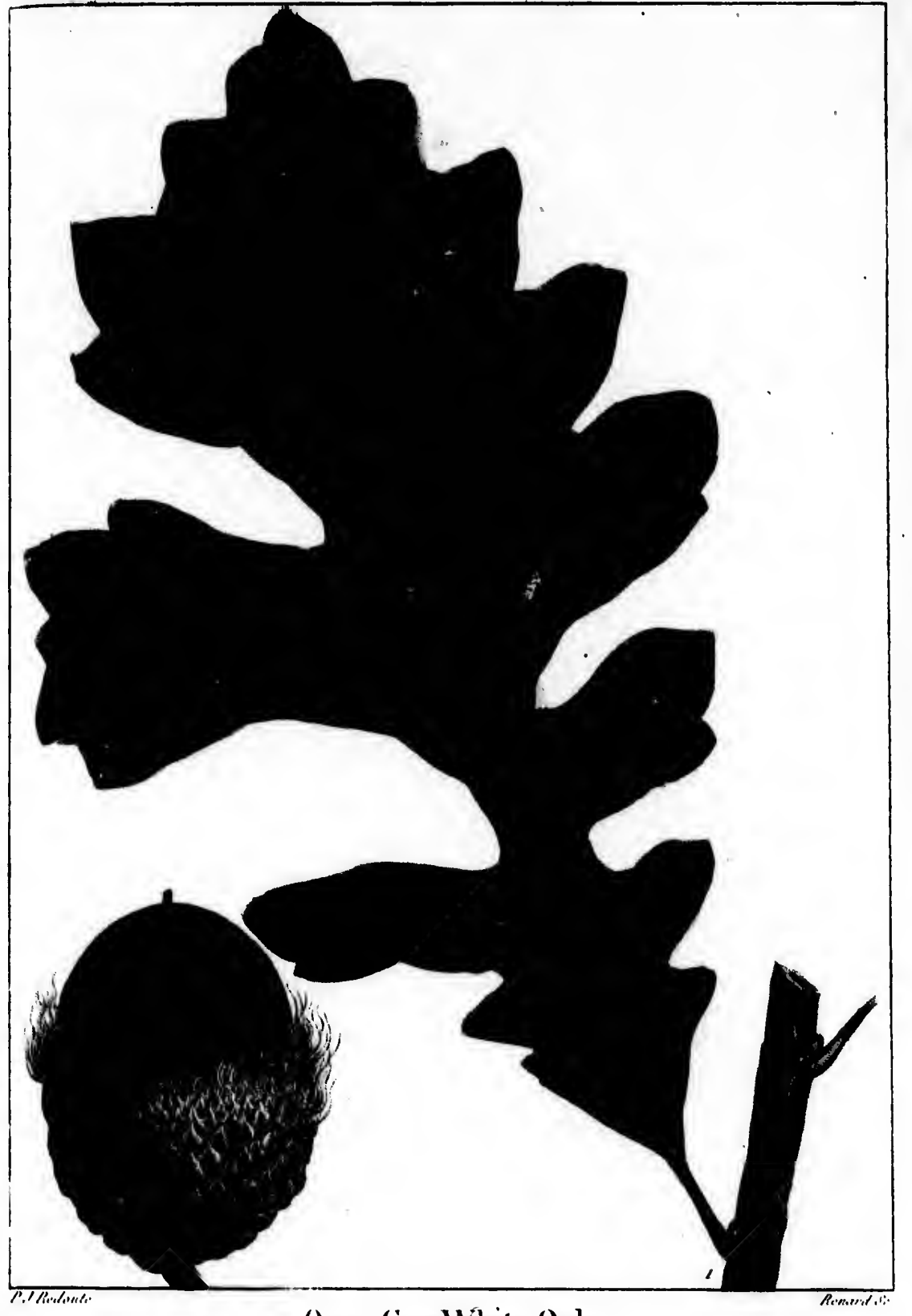

Over ('un White Oak.

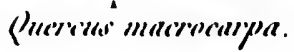



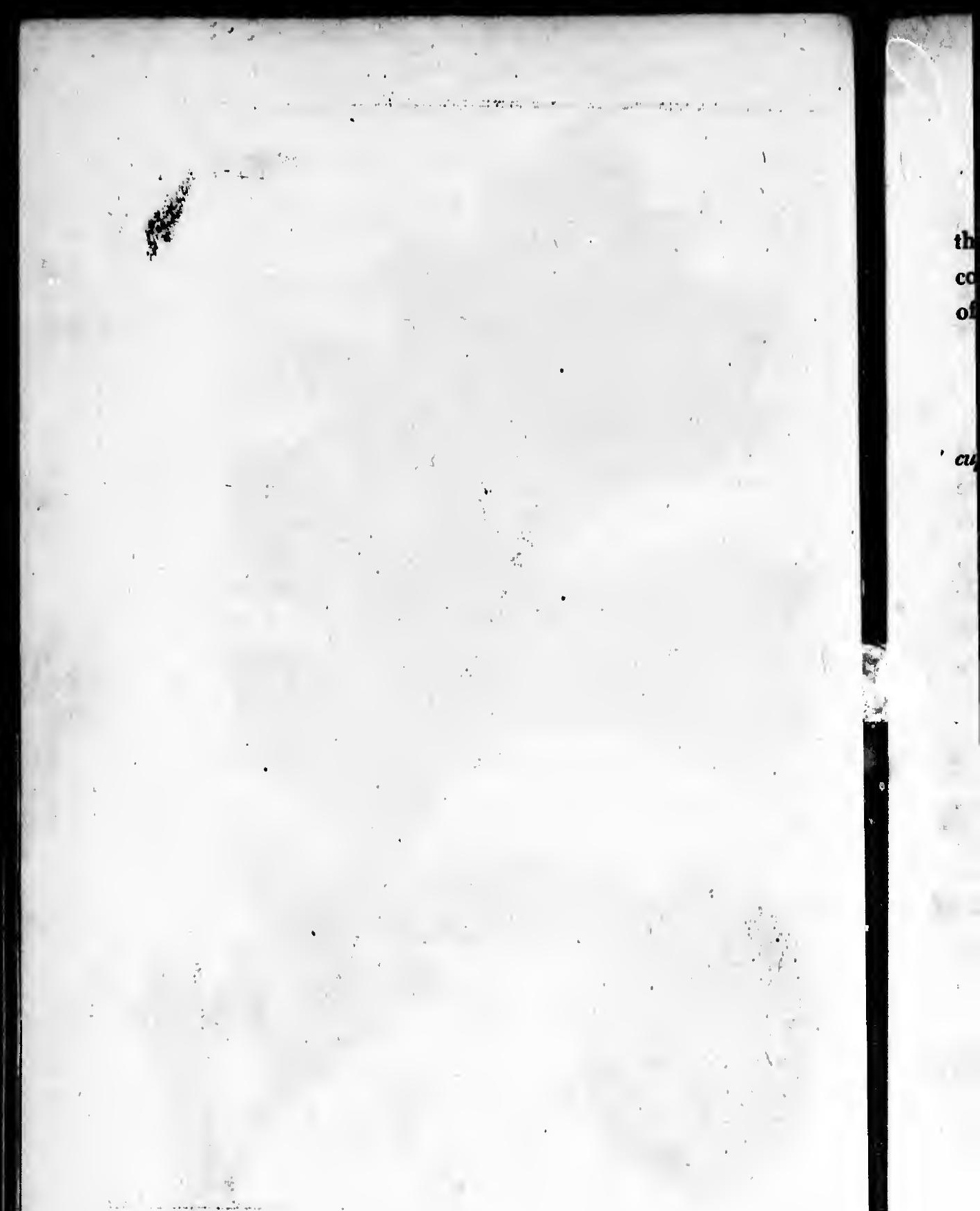
I havi observed, as well as my father who first made the reriark, that the young branches are frequently covered with a yellowish fungous substance, like those of the Elm and Sweet Gum.

\section{PLATE IV.}

1 leaf of half the natural size. Fig. 1, An acom in the ' cup, of the natural size. 


\section{POST OAK.}

Quencus obtusnoba. $Q$. foliis sinuatis, subtus pubescentibus, lobis obtusis, superioribus dilatatis, bilobis; fructu mediocri; glande brevi-ovata.

Quorcus stellata, WiLio. 8p. PI.

IN New Jersey near the sea, and in the vicinity of Philadelphia, this species is thinly disseminated in the forests, and has hitherto been considered as a variety of the White Oak. In Maryland and a great part of Virginia, where it abounds and where its properties are better understood, it is called Box White Oak, and sometimes Iron Oak and Post Oak. The last denomination only is used in the Carolinas, Georgia and East Tennessee.

The steep banks of the Hudson, nearly opposite to the cily of New York, are the most northern points at which I have observed it. Even here its existence seems to be secured only by the influence of the sea-air, which tempers to a certain degree the severity of the winter. A little farther inland it is not found in the forests. In the vicinity of South Amboy, 3o miles nearer the sea, where the soil is dry and sandy, it is more multiplied, and it becomes still more vigorous and more common in advancing towards the south. West ward in Pennsylvania I saw the last individual of this species a little beyond Carlisle on the road to Pittsburgh, I50 miles from Philadelphia. Near Baltimore, at the distance of 210 miles 


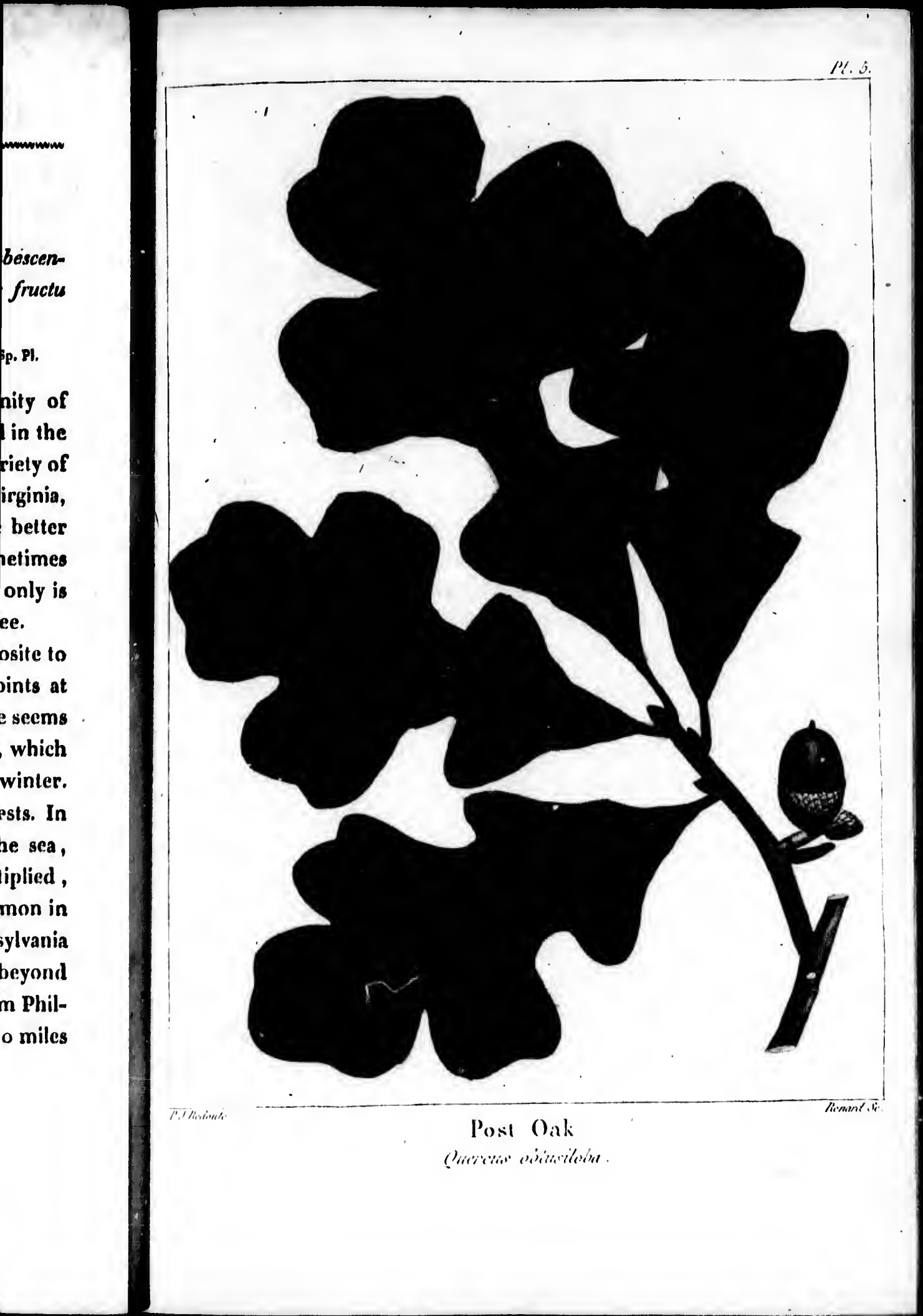




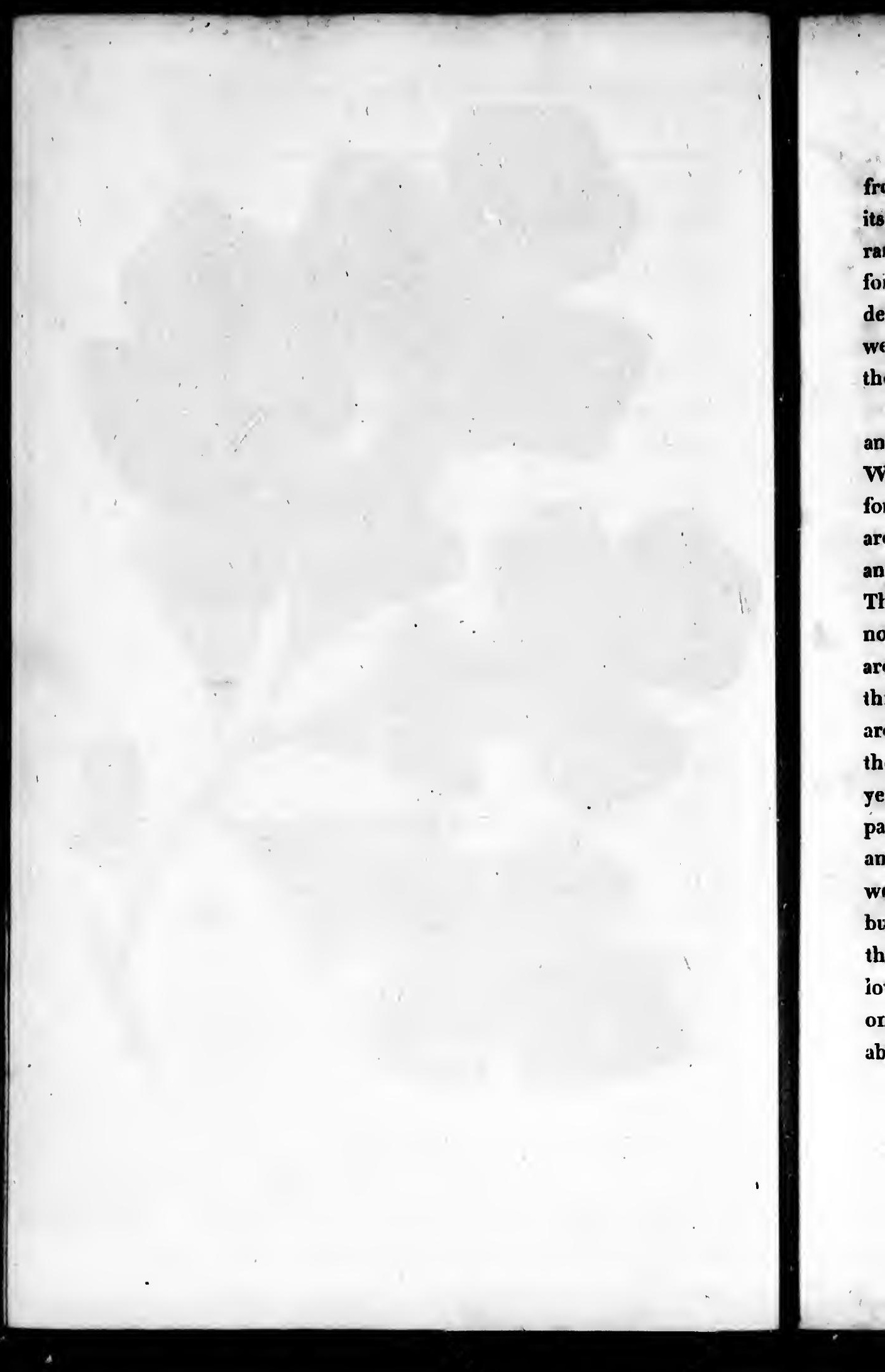


from New York, it abounds in the woods, and attains its utmost expansion. In Kentucky and Tennessee it is rare, except on the edges of the swamps enclosed in the forests, about which it is multiplied though not-fully developed. It probably exists in Lower Louisiana ; for ${ }^{y}$ we met with it in East Florida, of which the climate is. the same. :

But it is no where more abundant than in Maryland and in Virginia, between the Alleghanies and the sea. Wherever the soil is dry, gravelly and unsubstantial, it forms a considerable proportion of the forests, which are composed principally of the Blark, Scarlet, Spanish and Black Jack Oaks, the Dogwood and the Yellow Pine: These woods exhibit a squalid appearance, occasioned not only by the sterility of the soil, but by the injury they. are constantly sustaining from the cattle which range through them at all seasons, and which in the :winter. are compelled, by the want of herbage, to subsist upon the young sprouts and the shoots of the preceding year. The upper part of the two Carolinas and Georgia, particularly where the Pine and Oak forests unite, is analogous in soil to that portion of Virginia of which we have been speaking, and abounds in the Post Oak; but nearer the sea the barren wastes are covered with the Long-leaved Pine, and the Oak is seen only in the lowest parts of the swamps, about the plantations, and on tracts that have been exhausted by cultivation and abandoned. 
The leaves are borne by short petioles, and are divided into four or five rounded lobes, of which the two nearest the summit are the broadest; they are coriaceous, of a dusky green above and greyish beneath. Towards the fall the ribs are of a rosy tint, instead of a purplish red like those of the Scarlet Oak. The fructitication seldom fails. The acorns are small, oval, and covered, for a third of their length, with a slightly rugged greyish cup. They are very sweet, and form a delicious food for squirrels and wild turkeys; hence the tree is sometimes called Turkey Oak.

The height of this species rarely exceeds 40 or 50 feet, with a diameter of 15 inches. Its summit, even when compressed in the forests, is disproportionately large, owing probably to the early division of the trunk into several limbs, with which the secondary branches form more open angles than is common on other trees. The branches also are bent into elbows at certain distances, which gives so peculiar an appearance to the tree that it is easily distinguished when the leaves are fallen. The bark upon the trunk is thin and of a greyish white. The wood is yellowish, with no tinct of red. Growing upon a less humid soil, it is less elastic, but finer-grained, stronger and more durable, than the White Oak : hence it is preferred for posts, and is used with advantage by wheel-wrights and coopers.

In ship-building it is used principally for the knees, and is admitted into the lower part of the frame. It rarely 
POST OAK.

39

fur niches side-planks or timber of considerable length ; for this reason it is less esteemed than the White Oak, and it is, besides, less common except in Maryland and certain parts of Virginia.

The preference given in the West Indies to the staves from Baltimore and Norfolk is due, in a great measure, to their being made of the Post Oak:

This tree, though only of secondary size, should be propagated in America and introduced into the forests of Europe.

PLATE v.

A branch with leaves and frost of the natural size.

knees,

t rarely 
40.

\section{OVER-CUP OAK.}

Quzncos rynata. Q. foliis subsessilibus; glabris, lyratosinuosis, summitate dilatatd, dicaricato-trilobd, lobis actutangulis, terminali tricuspide; cupuld depresso-globosd, muricato scabratá; glande subtectd.

IN the United States I have met with this interesting species only in the lower part of the Carolinas and of Georgia. It probably exists on the hanks of the Mississippi in Lower Louisiana, and I have observed it on the St. John in East Florida, in situations analogous to those in which it flourishes a little farther north. In Georgia and Carolina it is not extensively multiplied, and has been distinguished only by the inhabitants of the places where it grows. It is called Swamp Post Oak, Over-cup Oak, and Water White Oak. The first of these denominations indicates an analogy hetween its foliage and that of the Post Oak, and the second, a remarkable peculiarity of its fruit, of which the acorn is covered by the cup. The name of Over-cup Oak is the mosi common in South Carolina, and that of Swamp Post Oak on the Savannah in Georgia.

The Over-cup Oak grows in more humid situations than any other species of this genus in the United States: It is never seen in the long narrow marshes which intersect the pine-barrens, but is found exclusively in the 


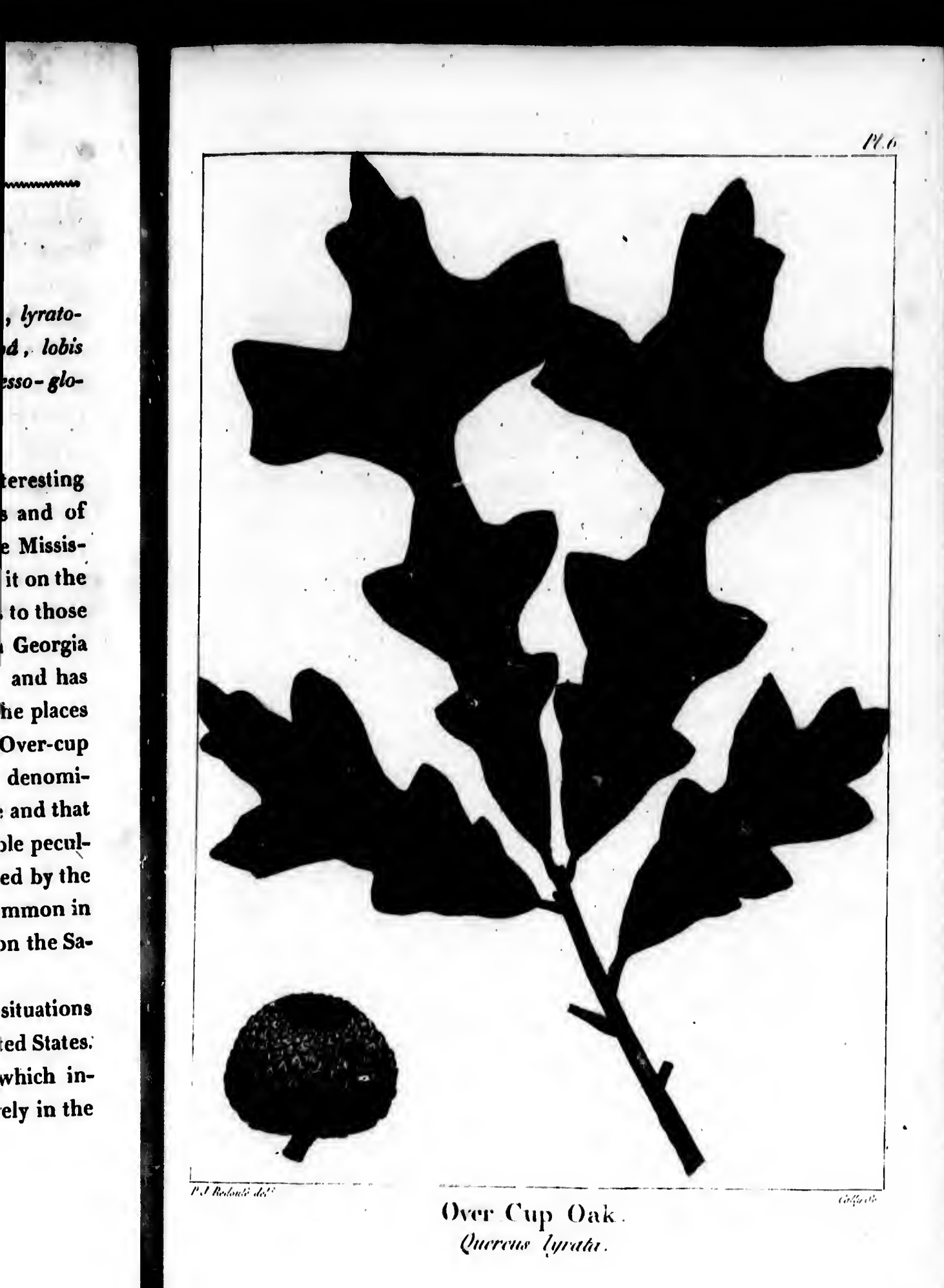




of
of
Bi
de
of
se
81
lo
bo
up
in
na
lig
in
br
so
si
T
ar
th
th


OVIn-cup OAx.

great swamps on the borders of the rivers, which are often overflowed at the rising of the waters, and are inaccessible during three quarters of the year. In these gloomy forests it is united with the Large Tupclo, White. Elm, Wahoo, Planer Tree, Carolinian Poplar, Water Bitternut Hickory and Water Locust.

It expands to a majestic size, and the influence of a deep and constantly humid soil is shown in the luxuriancy of its vegetation. On the banks of the Savannah I have seen stocks which were more than iso feit high an from 8 to 12 feet in circumference. The leaves are 6 or 8 inches long, smooth, narrow, lyre-shaped, decply sitiualed, and borne by short petioles. The lobes, particularly th: "wo upper ones, are truncated, and from thuir resentuance in this respect to those of the Post Uak, illerived the name of Swamp Post Oak. The foliage is thick orid of a light agreeable tint. The acorns, unlike those: of the Oaks in general which are of an elongated oval shape, are broad, round, and depressed at the sun :rit : they are sometimes from 12 to 18 lines in diameter from side to side, and from 6 to 10 lines from the buse to the summit. The cup, which is nearly closed, is thin, and its scales are terminated by short firm nnints.

The bark upon the trunk is white, and the wood, though inferior to that of the White Ouk and the Pust Oak, is more compact than would be supposed from the soil in which it grows; the pores are observalsle 
only betwcen the concentrical circles, and are more regularly disposed than in other trees.

This species is the largest and the most bighly esteemed among the Oaks that grow in wet grounds. Its propagation should be attempted in the forests of Europe, where no doubt can be entertained of its success. The acorns which I sent to France several years since, though sown upon uplands, have produced flourishing plants, which bear the winter of Paris without injury.

\section{PLATE VI.}

A branch with leaves and fruit of the natural size. 

P1. 7 .

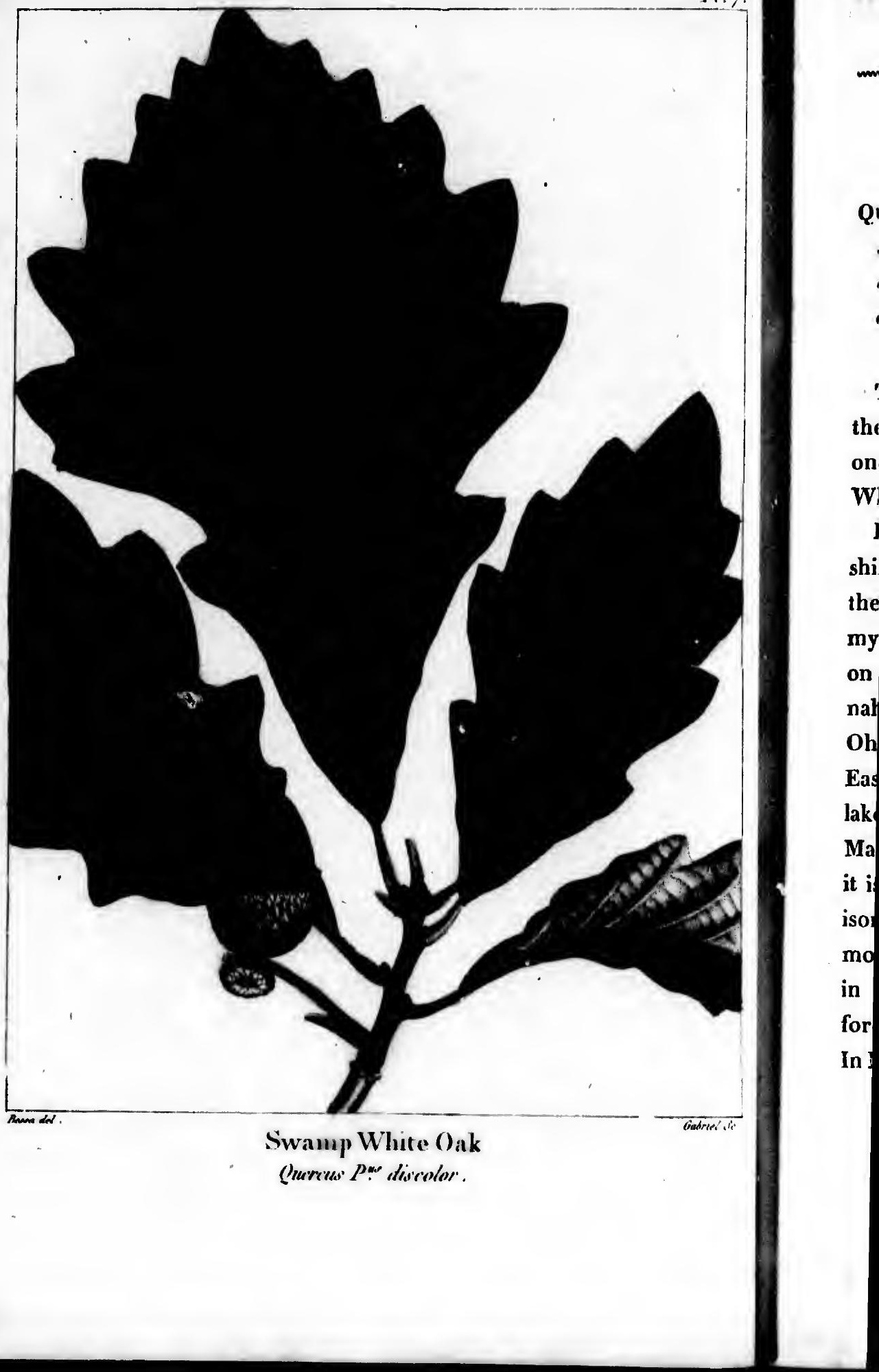




\section{SWAMP WHITE OAK.}

Quncus prinus Discolor. $Q$. foliis oblongo-obovatis, subtus albo-tomentosis, grosse dentatis, basi integerrimis, dentibus inaqualibus dilatatis; fructibus longe pedunculatis.

Quercus bicolor. WiLıv.

Tris species is known in the United States only by the name of Swamp White Oak, which indicates at once the soil which it prefers and its analogy to the White Oak.

I first observed it near Portsmouth in New Hampshire : but it is less multiplied in this latitude than in the Middle and Western States. It particularly attracted my attention in New Jersey near the city of New York, on the Delaware in Pennsylvania, on the Susquehannah in Virginia, and beyond the mountains on the Ohio in Kentucky and on the Holston near Knoxville in East Tennessee; I have also seen it on the shores of lake Champlain and lake Ontario. Except the District of Maine and the maritime parts of the Southern Scction, it is diffused throughout the United States; in comparison, however, with several other species, it is not common; being found only on the edges of swamps and in wet places exposed to inundations, and not in the forests at large, like the White Oak, the Black Oak, etc. In New Jersey it is associated with the Pin Oak, the Red- 
flowering Maple, the White Ash, the Tupelo and the Shell-bark Hickory. On the shores of Lake Champlain, which occasionally offer similar situations, particularly at a little distance from Skeensborough, it is mingled with the White Maples, which occupy the next line to the Willows in retiring from the shore.

The Swamp White Oak is a beautiful tree, more than 70 feet in height, of which the vegetation is vigorous and the foliage luxuriant. The leaves are 6 or 8 inches long and 4 inches broad, smooth and of a dark green above, downy and lighter coloured beneath; they are entire towards the base, which is cuneiform, but are widened and coarsely toothed for two thirds of their length towards the summit. The tree is distinguished; when young, by the form of its base and by the down upon its leaves, which is more sensible to the touch than on any analogous species. At a riper age the lower side of the leaf is of a silvery white, which is strikingly contrasted with the bright grcen of the upper surface; hence the specific name of discolor was given it by Dr. Muhlemberg.

The acorns are sweet, but seldom abundant ; they are ratber large, of a brown complexion, and contained in a spreading cup edged with short slender filaments, more downy within than those of any other Oak, and supported by peduncles $\mathrm{I}$ or 2 inches in length.

The trunk is clad in a scaly greyish white sark. The wood is strong, clastic, and heavier than that of the 
White Oak. In stocks more than a foot in diameter the grain is fine and close, and the pores are nearly obliterated. It splits easily and in a straight line, and is esteemed next in quality to the White Oak, though from its rareness it is but accidentally employed in the arts.

If,' as I incline to believe, the Swamp White Oak is found by more accurate experiments to be superior to the White Oak, it must be considered as a very valuable tree, and its increase should be favoured at the expense of the Red-flowering Maple, the Bitternut Hickory, the Hornbeam, and other species which grow in the same exposures. It seems also to deserve a place in the forests of Europe, where, in moist grounds, it might be blended or alternated with the Ashes, the Alders and the Poplars.

\section{PLATE VII.}

A branch with leaves and fruit of the natural size.

they are ained in aments, ak, and ark. The the of the 
46

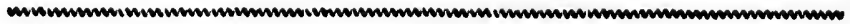

\section{CHESNUT WHITE OAK.}

Quercus prinus palustris. Q. foliis oblongo-ovalibus, acuminatis acutisve, subuniformiter dentatis; cupuld craternta, subsquamosd; glande ovatd.

Quercus prinus. Wiesd.

Tux Chesnut. White Oak is first seen within ten miles of Philadelphia; but it is less multiplied and less amply developed than farther south. It is most abundant in the maritime parts of the Carolinas, Georgia and East Florida, and is probably found on the banks of the Mississippi, which are analogous to those of many rivers of the Southern States.

In Pennsylvania this species is confounded with the Rock Chesnut Oak, which it strikingly resembles; farther South, where the Rock Chesnut Oak is unknown, it is called Chesnut White Oak, Swamp Chesnut Oak, and generally on the Savannah White Oak.

The Chesnut White Oak is adorned with beautiful foliage : the leaves are 8 or 9 inches long, 4 or 5 inches broad, obovate, deeply toothed, of a light shining green above and whitish beneath.

The acorns are brown, oval, larger than those of any other species except the Over-cup White Oak, and contained in shallow scaly cups. Being sweet-flavoured, and sometimes abundant, they are sought with avidity by 


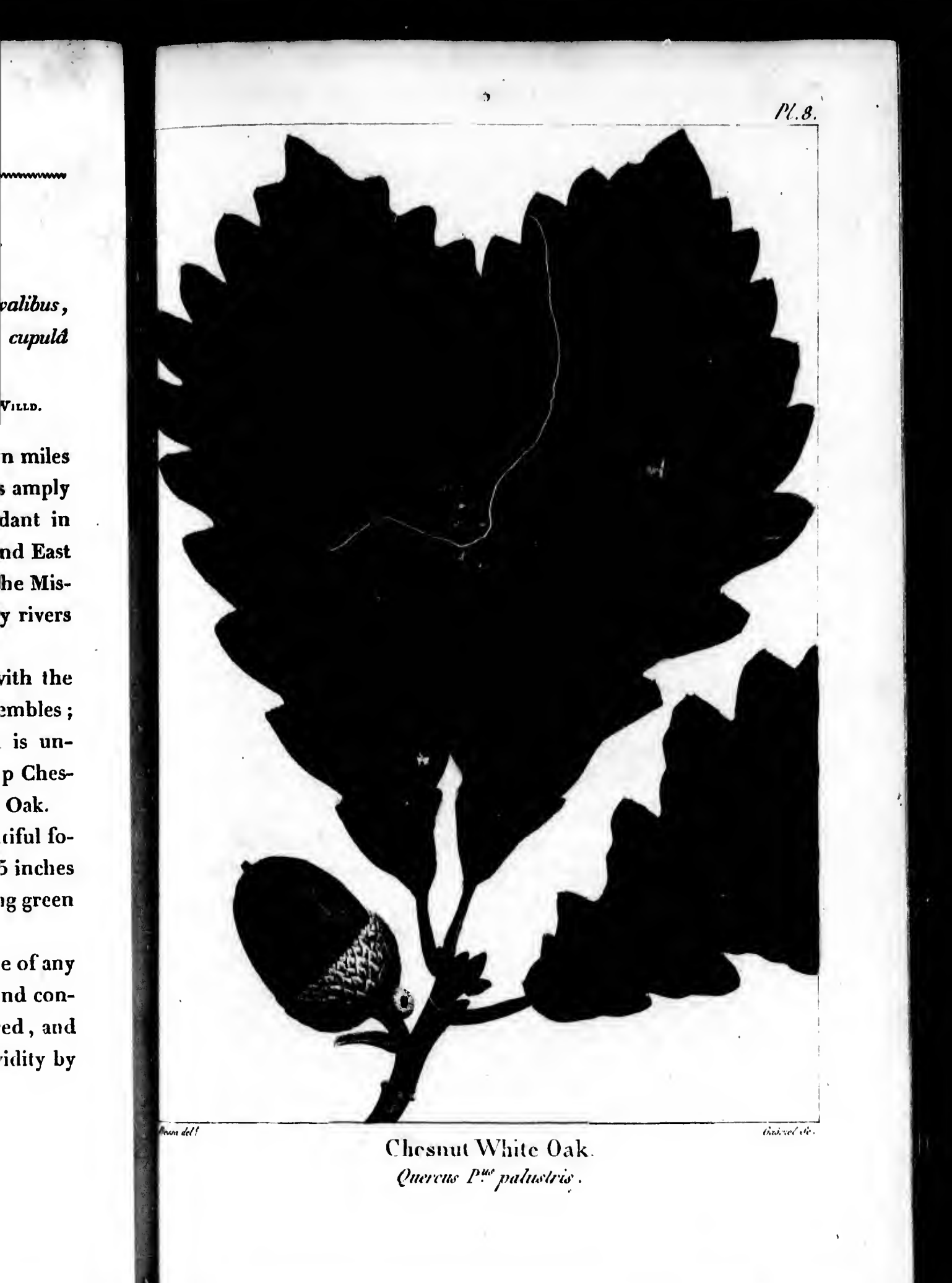




wild
and
grov
are
that
cons
In
by 1
Uml
lar,
latit
or 9
strai
heig
form
the
Its
soil,
Oak
thou
supe
whee
quire
line,
by th
open
of ra


wild and domestic animalo, such as deer, cows, horses and swine.

The Chesnut White Oak, like the Over-cup Oak, grows only in the large swamps that border the rivers or are enclosed in the forests; but it always chooses spots that are rarely inundated, where the soil is loose, derp, constantly conl and luxuriantly fertile.

In the Carolinas and Georgia it is usually accompanied by the White EIm, the Wahoo, the Big Laurel, the Umbrella Tree, the Sweet Leaves, the Beech, the Poplar, the Bitternut llickory and the Devil Wood. In this latitude it altains its utmost developement, which is 80 or 90 feet in stature with a proportional diameter. Its straight trunk, nndivided and of an uniform size to the height of 50 fect, and its expansive lufted summit, form one of the most beautiful and majestic trees of the North American forests.

Its wood, which is affected by the richness of the soil, is inferior to that of the Post Oak, the White Oak, and even the Over-cup Oak; and its pores, though nearly obliterated, are more open. But it is superior to many other species, and is employed for wheel-wrights' works and for other objects which require strength and durability. As it splits in a straight line, and may be divided into fine shreds, it is chosen by the negroes for baskets and brooms. Its pores are too open to contain wine or spirituous liquors. In the form of rails it lasts 12 or 15 years, or a third longer than the 
Willow Oak. At Augusta in Georgia it is considered as the best fuel, and is sold at 2 or 3 dollars a cord.

The Chesnut White Oak endures the winter of Paris, but its vegetation would be quicker in the more southern departments. It is to be regretted that a tree which seems formed to be one of the finest ornaments of our forests, should have nothing to recommend it but its beauty. Other properties it possesses only in a secondary degree, and in Europe it will probably be confined to the pleasure-grounds of amateurs.

\section{PLATE VIII.}

$A$ branch with leaves and fruit of the natural size. 
dered as 1. of Paris, e southee which ts of our it but its isecondconfined

size. 


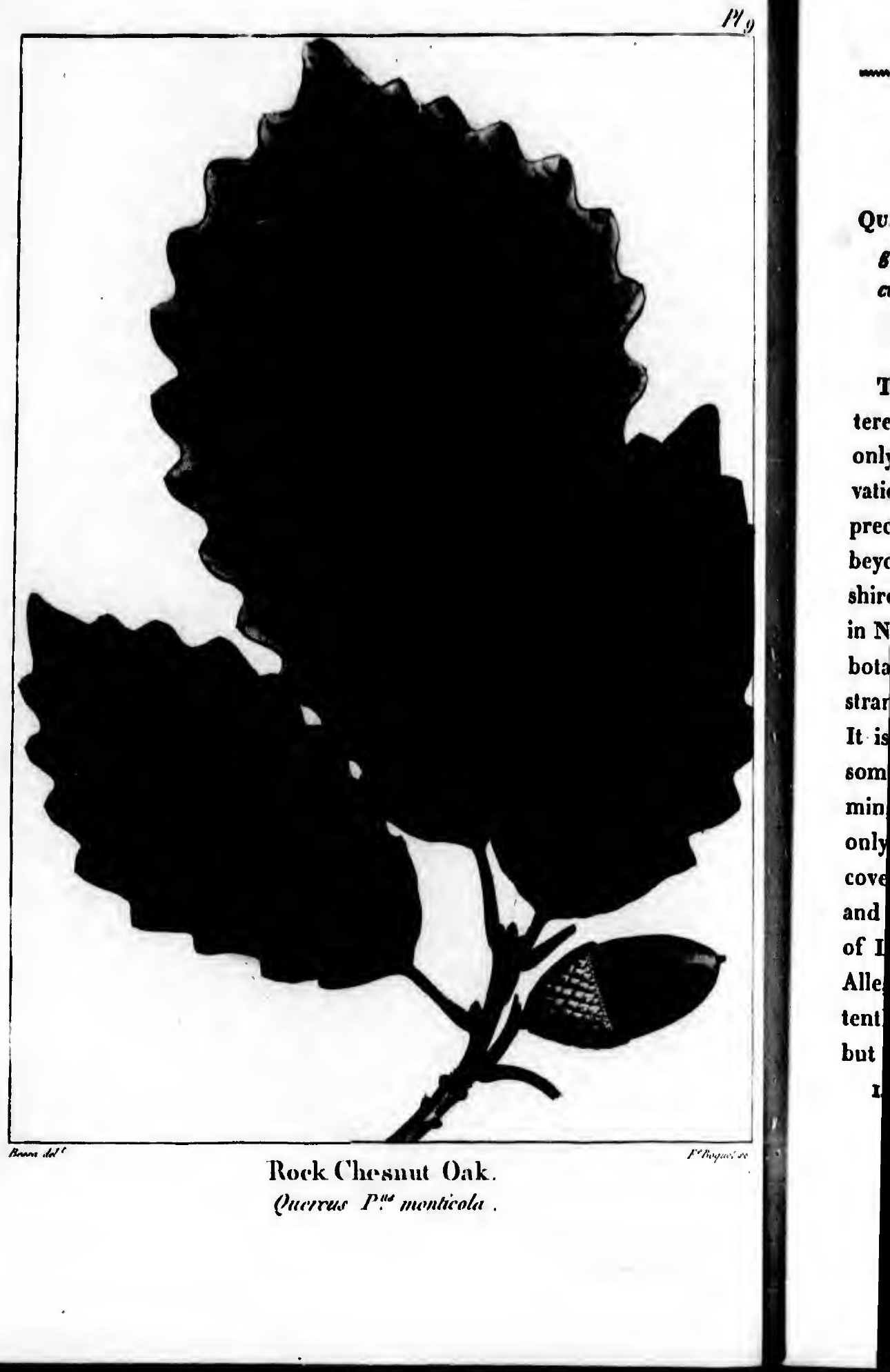




\section{ROCK CHESNUT OAK.}

Quencus pnivus moxticura. Q. foliis olsovatis acutis, grosse dentatis, dentibus subcequalihus; fructus majus culo, cupuld turbinata, scubrosd; slande oblongd.

Quereus moniane, Witho.

Tris Oak is among the species which are not scattered promiscuously in the forests, but which grow only in particular situations and easily escape observation; hence it is difficult to assign its limils with precision. It probably does not extend northward far beyond Vermont, nor eastward beyond Now llampshire. I have never seen it in the District of Maine nor in Nova Scotia, and it is not mentioned in my father's botanical noles upon Lower Canada ; it is likewise a stranger to the maritime parts of the Southern Slates. It is most frequently met with in the Middle and in some parts of the Northern Sections; but is rarely mingled with other trees in the forests, and is found only on high grounds thickly strewed with stones or covered with rocks. Thus it is often seen on the stecp and rocky banks of the Hudson and on the shores of Lake Champlain, and still more frequently on the Alleghanies in. Pennsylvania and Virginia. It forms nine tenths of the growth on some parts of these mounlains, but the soil is so meager that it is thinly disseninated 
and does not exceed 20 or 25 feet in height and 8 or vo inches in diameter. I made this observation particularly on the Dry Ridges 15 miles from Bedford.

In that part of Pennsylvania, as well as in Maryland and Virginia, it is known by the name of Chesnut Oak, and by that of Prock Oak on the banks of the Hudson and the shores of Lake Champlain to the distance of 400 miles from New York. Both are significant ; the first, of a remarkable resemblance of the bark to that of the Chesnut; and the second, of the situations in which the tree is exclusively found. For this reason, and to avoid confounding it with the preceding and following species, which also grow in Virginia, I have blended the two denominations.

The beautiful appearance of this tree when growing in a fertile soil, is owing equally to the symmetry of its form and to the luxuriance of its foliage. The leaves are 5 or 6 inches long, 3 or 4 broad, oval and uniformly denticulated, with the teeth more regular but less acute than those of the Chesnut White Oak. When beginning to open in the spring, they are covered with a thick down; but, when fully expanded, they are perfectly smooth, whitish beneath, and of a delicate texture. The petiole is of a yellow colour, which becomes brighter towards the fall.

The acorns are brown, of an oblong-oval shape, and sometimes an inch in length, a third part of which is contained in a spreading cup covered with loose scales : 
they are sweet-tasted and are a favourite nourishment of wild and domestic animals.

The Rock Chesnut Oak is sometimes 3 feet in diameter, and more than 60 feet high ; but as its growth is usually repressed by the poverty of the soil, it rarely attains these dimensions: In open elevated situations it spreads widely, and forms a head like that of the Apple Tree. When the trunk exceeds a foot in diameter it is covered with a thick, hard, deeply furrowed bark. At New York and near the Alleghanies in Pennsylvania, this species of bark is esteemed the best for tanning. Only that of the secondary branches and of stocks less than 6 inches thick is employed. It is sold at New York for 10 or 12 dollars a cord. The epidermis is strongly impregnated with the tanning principle, which in other species resides only in the cellular integument.

The wood is reddish like that of the White Oak, but its pores are more open, though its specific gravity is greater : pieces of both species being thrown into water, the White Oak remains on the surface and the other at the bottom. Its staves are not used to contain spirituous liquors. At New York and on the banks of the Hudson, it holds the next place to the White Oak in the construction of vessels. It is employed for the lower part of the frame, and oftener for the knces and the ribs : pieces of White Oak suited to these objects are procured with difficulty; but the Rock Chesnut Oak, growing up in a continual controversy with the winds, is more fre- 
52

ROCK CBESXUT OAR.

quently bent into the proper shape. For fuel, it is next in price to the Hickory. I have been told in several forges, especially those at the foot of the North Mountain, 200 miles from Philadelphia, that it is superior in this respect to every other species of its genus except the Live Oak.

A tree like this, which grows in stony soils, in abrupt uninhabitable exposures, and whose bark and timber are so valuable, deserves the particular altention of American and European forester: They should sow the acorns in the crevices of the rocks, and wherever the soil is incapable of cultivation. Thousands of young plants already exist in the vicinity of Paris.

\section{PLATE IX.}

A branch with leaves and fruit of the natural size. 



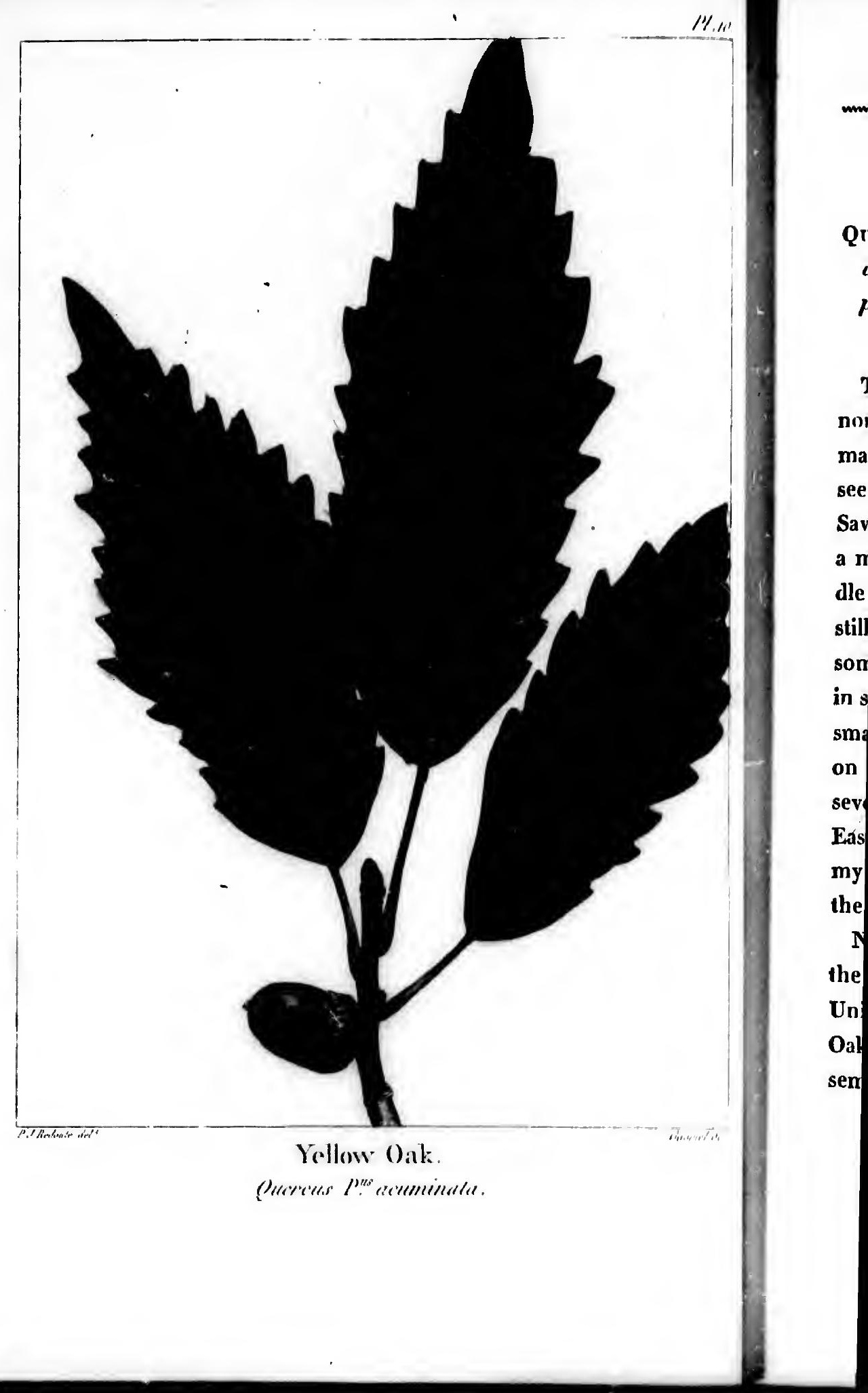




\section{3.}

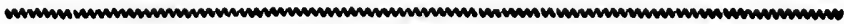

\section{YELLOW OAK.}

Quercus prinus actiminata. Q. foliis longè petiolatis, acuminalis, subaequaliter dentatis; fructu mediocri ; cupula subhermisphericá.

Quercus castanea, WizLo.

Tre banks of the Delaware may be assumed as the northern limit of the Yellow Oak. It scarcely exists in the maritime parts of the Southern States, where I have seen only a few stocks near Two Sisters' Ferry on the Savannah in Georgia, and a single one on the Cape Fear; a mile from Fayetteville in North Carolina. In the Middle and Western States, though more common, it is still rare in comparison with many other trees, and is sometimes lost sight of by the traveller for several days in succession. I have most particularly observed it on the small river Conestoga near Lancaster in Pennsylvania; on the Mononghahela a little above Pittsburgh, and in several small tracts near the Holston and Nolachuky in East T'ennessee. In the Monography of American Oaks, my father takes notice of its existence in the country of the Illinois.

Near Lancaster this tree is called Yellow Oak, from the complexion of its wood; but in other parts of the United States it is confounded with the Chesnut White Oak and Rock Chesnut Oak, to which it bears some resemblance in its foliage. 
The leaves are lanceolate, regularly toothed, of a light green above and whitish beneath. The small acorns are contained in slightly scaly cups, and are sweeter than those of any other species in the United States.

The Yellow Oak is a fine tree, 70 or 80 feet high and 2 feet in diameter, with branches tending rather to close round the trunk than to diffuse themselves horizontally. I invariably found it in vallies where the soil was loose, deep and fertile. The bark upon the trunk is whitish, very slightly furrowed, and sometimes divided into plates, like that of the Swamp White Oak: The wood is yellowish, though the tint is not bright enough to fit it for peculiar uses. Its pores are partly obliterated, irregularly disposed, and more numerous than those of any siher American Oak : this organisation must impair its strength and render it less durable than the Chesnut White Oak and the Rock Chesnut Oak.

As this tree is so thinly disseminated, it will not appear surprising that I should not have witnessed the application of its wood in the arts, or have found occasions of accurately appreciating its qualities. Its agreeable form and. beautiful foliage render it proper for the embeisishment of picturesque gardens.

PLATE X.

A branch wi.h haves and fruit of the natural size. 


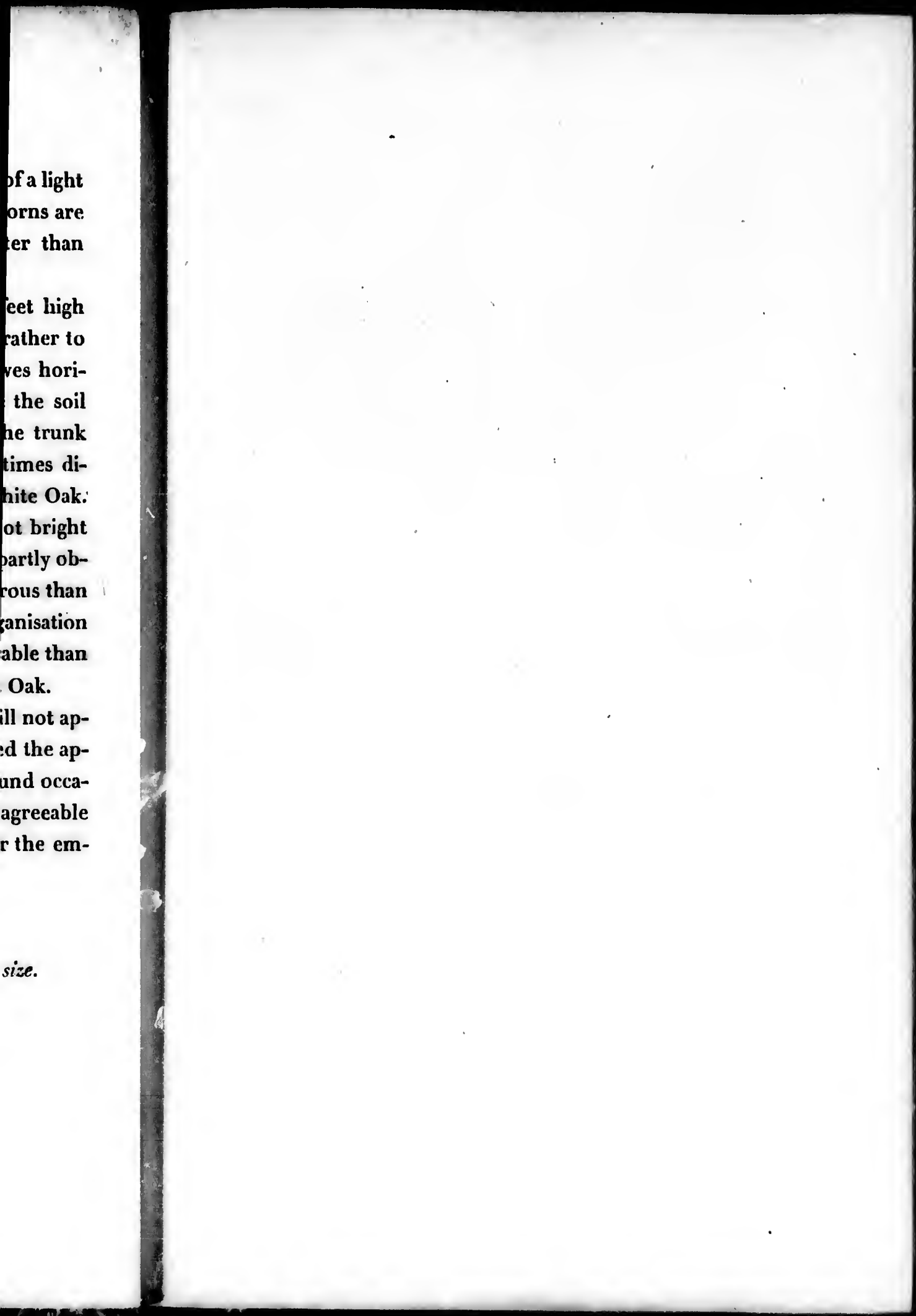




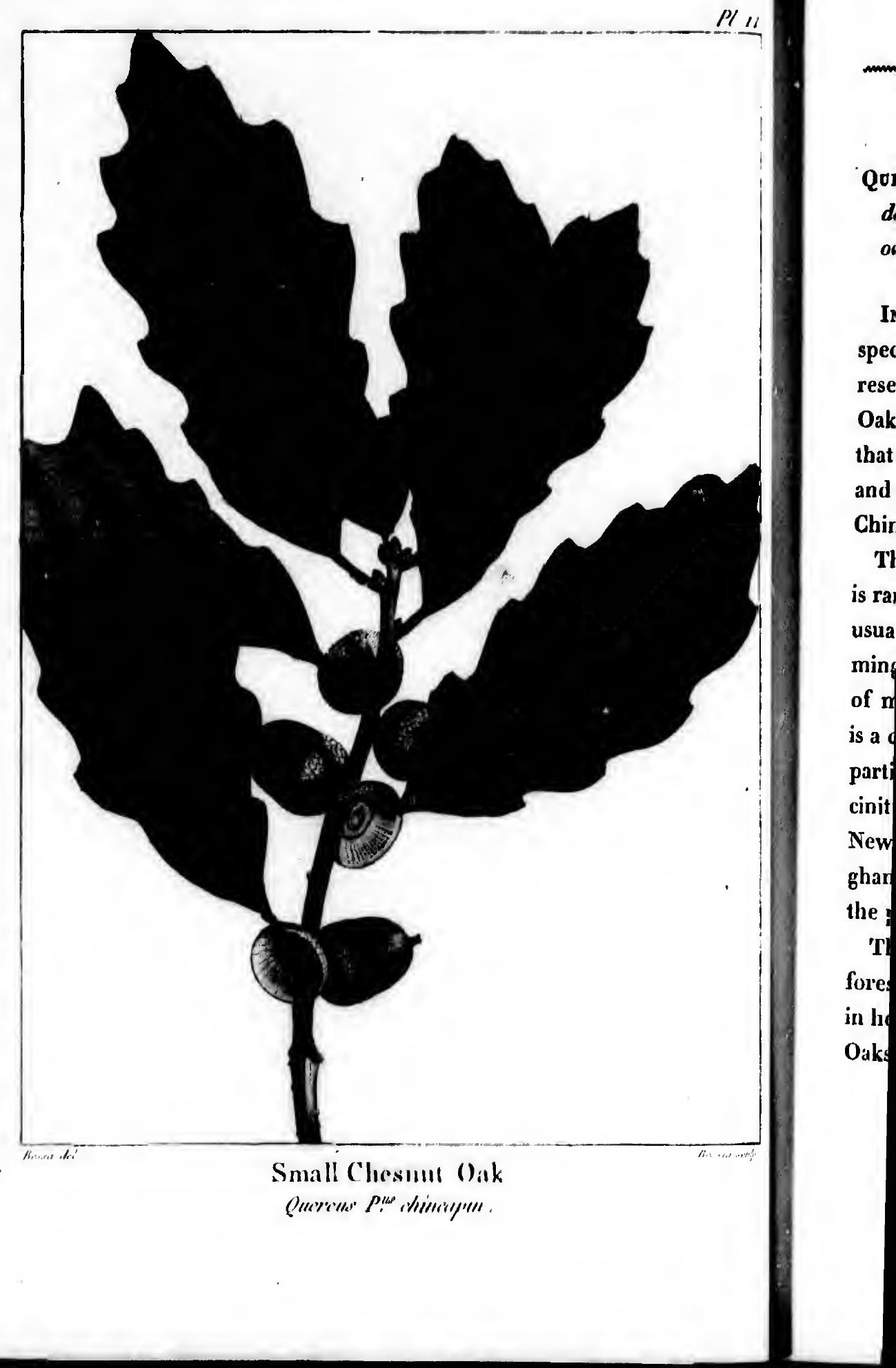




\section{SMALL CHESNUT OAK.}

QuzRcus painus chimcamin. Q. folüs obovatis, grosse dentatis, sublus glaucis; cupuld hemispharicd; glande ovatd.

Quercus prinoides, WiLLD.

In the Nortbern and Middle States this pretty little species is called Small or Dwarf Chesnut Oak, from the resemblance of its leaves to those of the Rock Chesnut Oak; as there is also a likeness between its foliage and that of the Chincapin, it is known in East Tennessee and in the upper part of the Carolinas by the name of Chincapin Oak.

The Small Chesnut Oak is not generally diffused, but is rare in many places adapted to its constitution, and is usually found in particular districts, where, alone or mingled with the Bear Oak, it sometimes covers tracts of more than 100 acres. The presence of these species is a certain proof of the barrenness of the soil. I have particularly observed the Small Chesnut Oak in the vicinity of Providence in Thode Island, of Albany in New York, of Kuoxville in Tennessee, and on the Alleghany Mountains in Virginia. It grows spontaneously in the park of Mr. W. Ilamilton near Philadelphia.

This species and another which is found in the Pine forests of the Southern States rarely exceed 3o inches in heiglit : they are the most diminutive of the American Oaks, and are mentioned only to complete the series. 
The leaves of the Srnall Chesnut Oak are oval-acuminate, regularly but not deeply denticulated, of a light green above and whitish beneath. The acorns are enclosed for one third of their length in scaly sessile cups; they are of a middle size, sowewhat elongated, similarly rounded at both ends, and very sweet.

Nature seems to have sought a compensation for the diminutive size of this shrub in the abundance of its fruit : the stem, which is sometimes no bigger than a quill, is stretched at full length upon the ground by the weight of the thickly clustering acorns. United with the Bear Oak, which is of the same size and equally prolific, perhaps it might be cultivated with advantage for its fruit.

PLATE XI.

A branch with leaves and fruit of the natural size. 
acumia light re encups ; milarly or the of its than a by the ith the rolific, for its 


$$
\text { [- }
$$




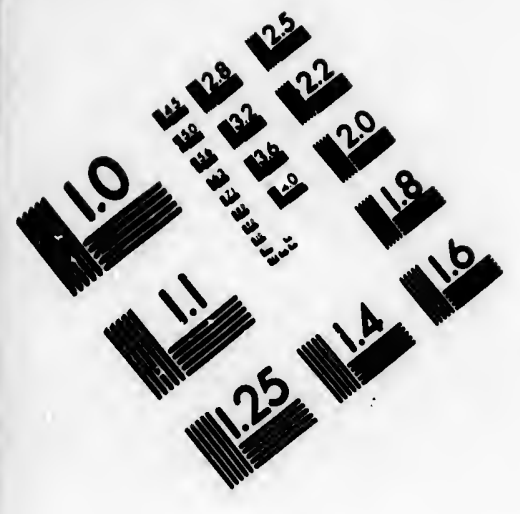

\section{IMAGE EVALUATION \\ TEST TARGET (MT-3)}
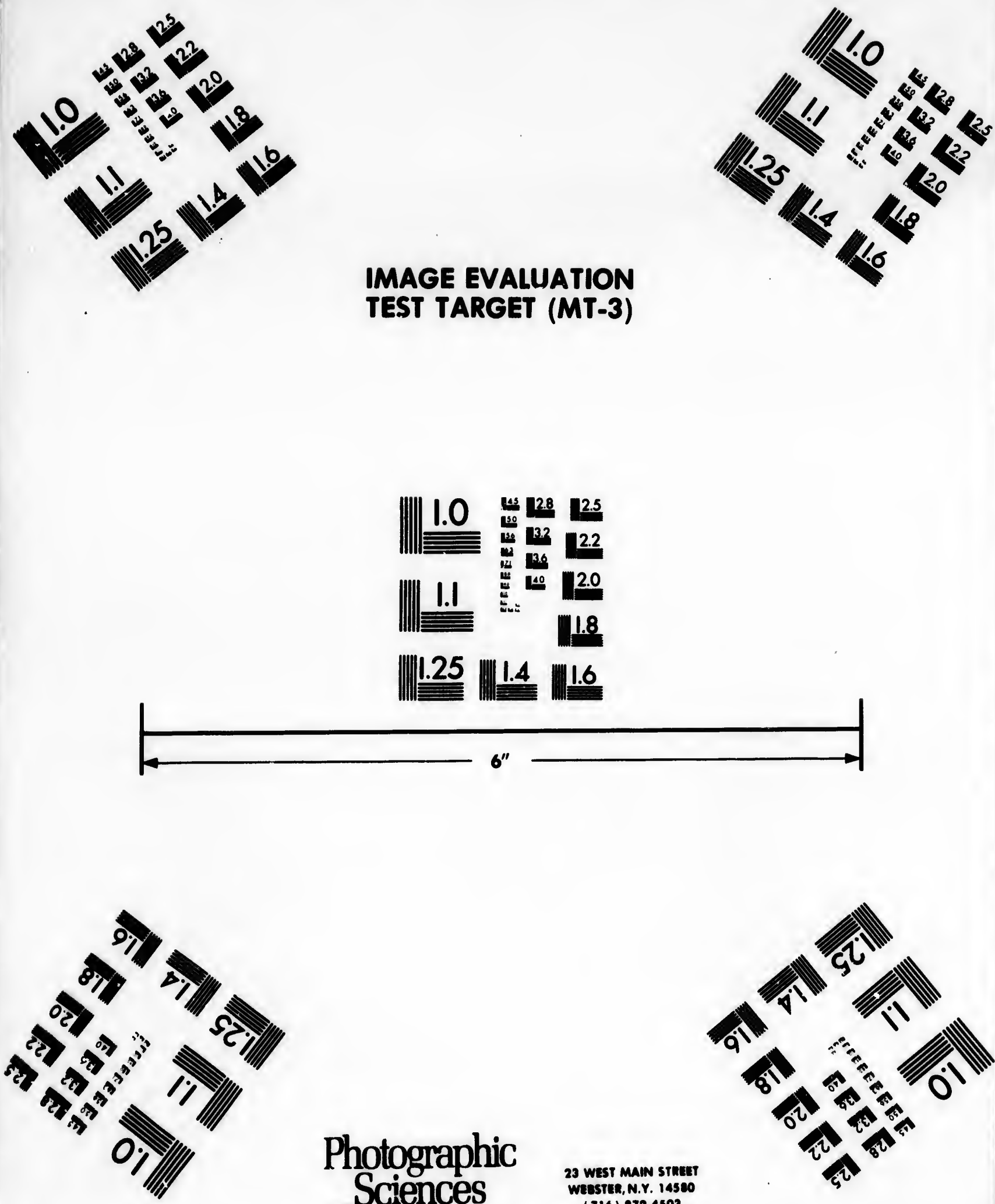

Photographic Sciences Corporation

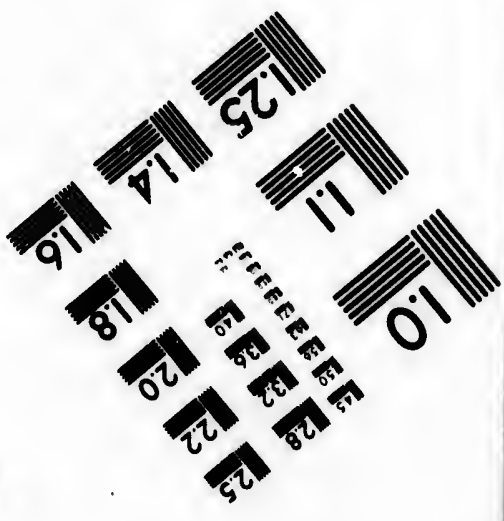




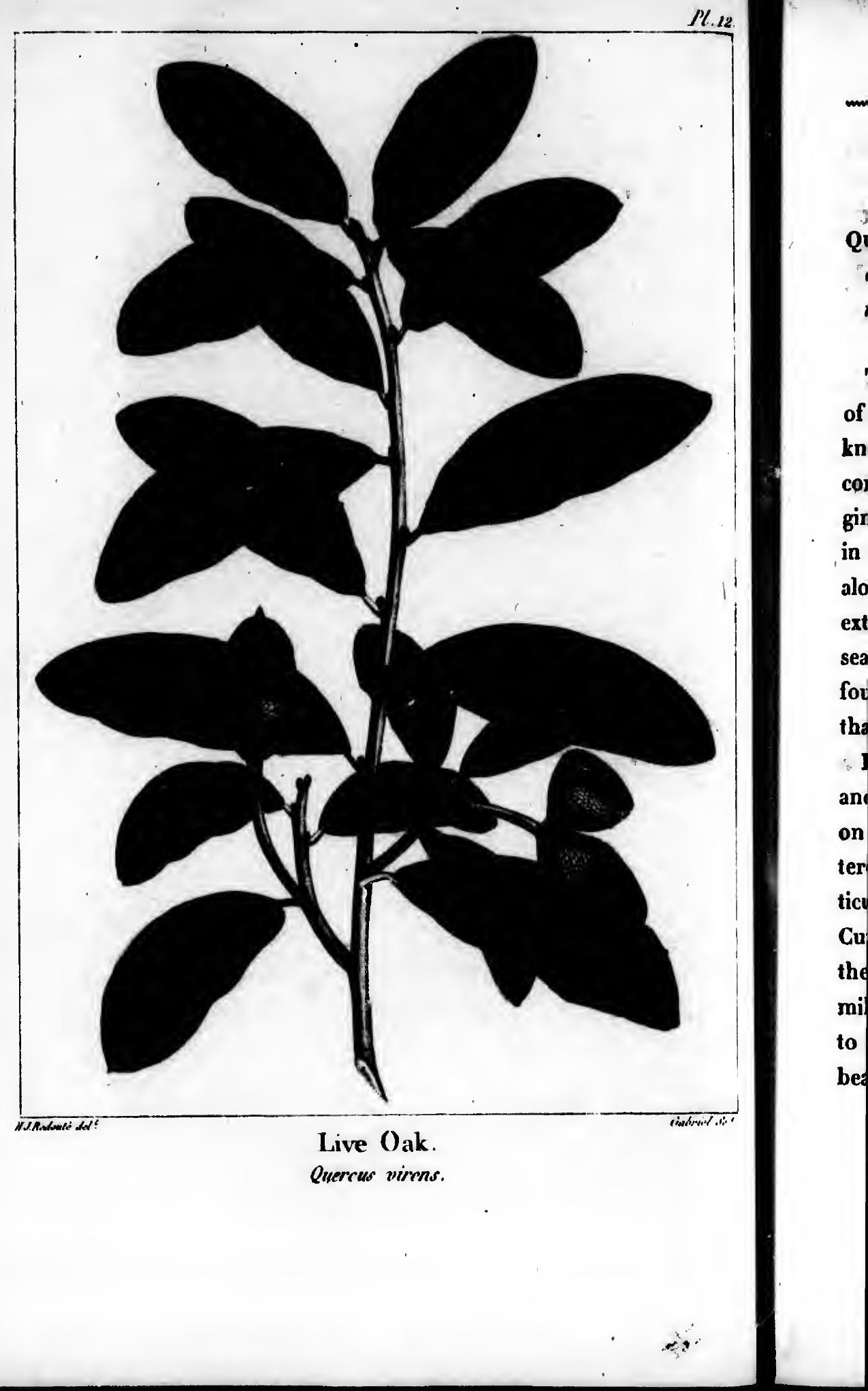




\section{LIVE OAK.}

QuRncus viness. $Q$. foliis perennantibus, coriaceis; ovatnoblongis, junionibus dentatis, vetustionibus integris; cupuld' turbinatd, squamulis abbreviatis; glande oblongd.

This species, which is confined to the maritime parts of the Southern States, the Floridas and Louisiana, is known only by the name of Live Oak. The climate becomes mild enough for its growth near Norfolk in Virginia, though it is less multiplied and less vigorous than in a more southern latitude. From Norfolk it spreads along the coast for a distance of 15 or 18 hundred miles, extending beyond the mouth of the Mississippi. The sea-air seems essential to its existence, for it is rarely found in the forests upon the mainland, and never more than 15 or 20 miles from the shore.

It is the most abundant, the most fully developed, and of the best quality, about the bays and creeks, and on the fertile islands which in great numbers lie scattered for several hundred miles along the coast. I particularly observed it on the islands of St. Simon, Cumberland, Sapelo, etc., between the St. John and the St. Mary, in an excursion of four or five hundred miles in a canoe, from Cape Canaveral in East Florida to Savannah in Georgia. I frequently saw it upon the beach, or half-buried in the moveable sands upon the

I. 
downs, where it had preserved its freshness and vigour, though exposed during a long lapse of time to the fury of the wintry tempest and to the ardour of the summer's sun.

The Live Oak is commonly 40 or 45 , feet in height, and from 1 to 2 feet in diameter; but it is sometimes much larger : Mr. S., president of the Agricultural Society of Charleston, assured me that he had felled a trunk, hollowed by age, which was 24 feet in circumference. Like most other trees, it has, when insulated; a wide and tufted summit. Its trunk is sometimes undivided for 18 or 20 feet, but often ramifies at half this height, and at a distance it has the appearance of an old Apple Tree or Pear Tree. The leaves are oval, coriaceous, of a dark green above and whitish beneath : they persist during several years, and are partially rentwed every spring. On trees reared upon plantations, or growing in cool soils, they are one half larger, and are often denticulated : upon stocks of two or three years they are commonly very distinctly toothed.

The acorns are of a lengthened oval form, nearly black, and contained in shallow, greyish, pedunculated cups. The Indians are said to have expressed an oil from them to mingle with their food; perhaps, also, they eat the kernel, which, though not agreeable to the taste, is less rough and bitter than that of many other species. The fruit is sometimes very abundant, and it germinates with such ease that if the weather is rainy at the

evir and

Oal sum stil

grea

clusi

com

Ced:

wid

adva

whis

yard

T

the

lowe

cons

who

are

Sou

Lon 
season of its maturity, many acorns are found upon the trees with the radicle unfolded. .

The bark upon the trunk is blackish, hard and thick. The wood is heavy, compact, tine-grained, and of a yellowish colour, which deepens as the tree advances in age. The number and closeness of the concentrical circles evince the slowness of its growth. As it is very strong, and incomparably more durable than the best White Oak, it is highly esteemed in ship-building and is consumed not only in the country which produces it, but still more extensively in the Northern States. From its great durability when perfectly seasoned it is almost exclusively employed for the upper part of the frame. To compensate its excessive weight it is joined with the Red Cedar, which is extremely light and equally lasting.

The Live Oak does not afford large timber; but its wide and branching summit makes amends for this disadvantage by furnishing a great number of knees, of which there is never a sufficient quantity in the dockyards.

The ressels built at New York and Philadelphia, with the upper frame of Red Cedar and Live Oak, and the lower timbers of White Oak, are as durable as those constructed of the best materials in Europe. Brekel, whom I have already quoted, says that the best trunnels are of Live Oak ; but at present it is replaced, in the Southern States, by the Locust and the heart of the Long-leaved Pine. 
In the South, particularly at Charleston and Savannah, this species is used for the naves and felloes of heavy wheels, for which it is far superior to the White Oak : it is more proper, also, for screws and for the cogs of mill-wheels.

The bark is excellent for tanning, but is only accidentally employed. .

Besides the Live Oak timber exported to England, great quantities are used in ship-building in the United States, particularly at Boston, New York, Philadelphia and Baltimore. The consumption has become threefold within twenty years, in consequence of the immense developement of American commerce. Hence the price bas doubled, and the species is rapidly diminishing. The clearing of the islands for the culture of cotton, which they yield of a superior quality, has contributed greatly to its destruction. It is already difficult to procure sticks of considerable size in the Southern States, and they are sought on the western coast of East Florida between the St. Mary and the St. John. From St. Augustine to the Cape the species is rarer; but we are informed that it abounds on the shores of West Florida, whither the English of the Bahame Islands resort for supplies.

As the Live Oak, from the peculiarities of its constitution, is multiplied with difliculty, I cannot but consider its disappearance throughout the United States within finty years as nearly certain. It will then be 
inv e OAK.

61

found only in the form of a shrub, like the Quercus ilex which formerly skirted the southern coast of France and Italy.

PLATE XII.

A branch with leaves and fruit of the natural size.

gland ;

United

delphia

reefold

nmense

he price

dishing.

cotton,

tributed

to pro-

States,

Last Flo-

From St.

at we are

Florida,

escort for

ts consti-

but con-

ed States

then be 


\section{CORK OAK.}

Quencus suber. $Q$. folïs obato-oblongis, indioisis, serratis, sublus glaucis; cortice rimoso, fungoso.

ThE Cork Oak grows naturally in the southern parts of France, in Spain, Portugal, Italy and the States of Barbary, which are comprised between the 4ith and 35th degrees of latitude. It rarely exceeds 40 fęet in height and 3 feet in diameter. Its leaves are evergreen, but the greater part of them fall and are renewed in the spring : they are ovate, thick, slightly toothed, of a light green on the upper surface and glaucous beneath. The acorns are rather large, oval, and half enclosed in a conical cup : as they are of a sweetish taste, they are eagerly devoured by swine.

The wood is hard, compact and heavy, but less durable than that of the Common European Oak, particularly when exposed to humidity. The worth of the tree resides in its bark, which begins to be taken off at the age of 25 years. The first growth is of little value; in ten years it is renewed; but the second product, though less cracked than the first, is not thick ęnough for corks, and is used only by fishermen to buoy up their nets. It is not till the tree is $\mathbf{4 5}$ or $\mathbf{5 0}$ years old that the bark possesses all the qualities requisite for good corks, and from that period it is collected once in eight or ten 


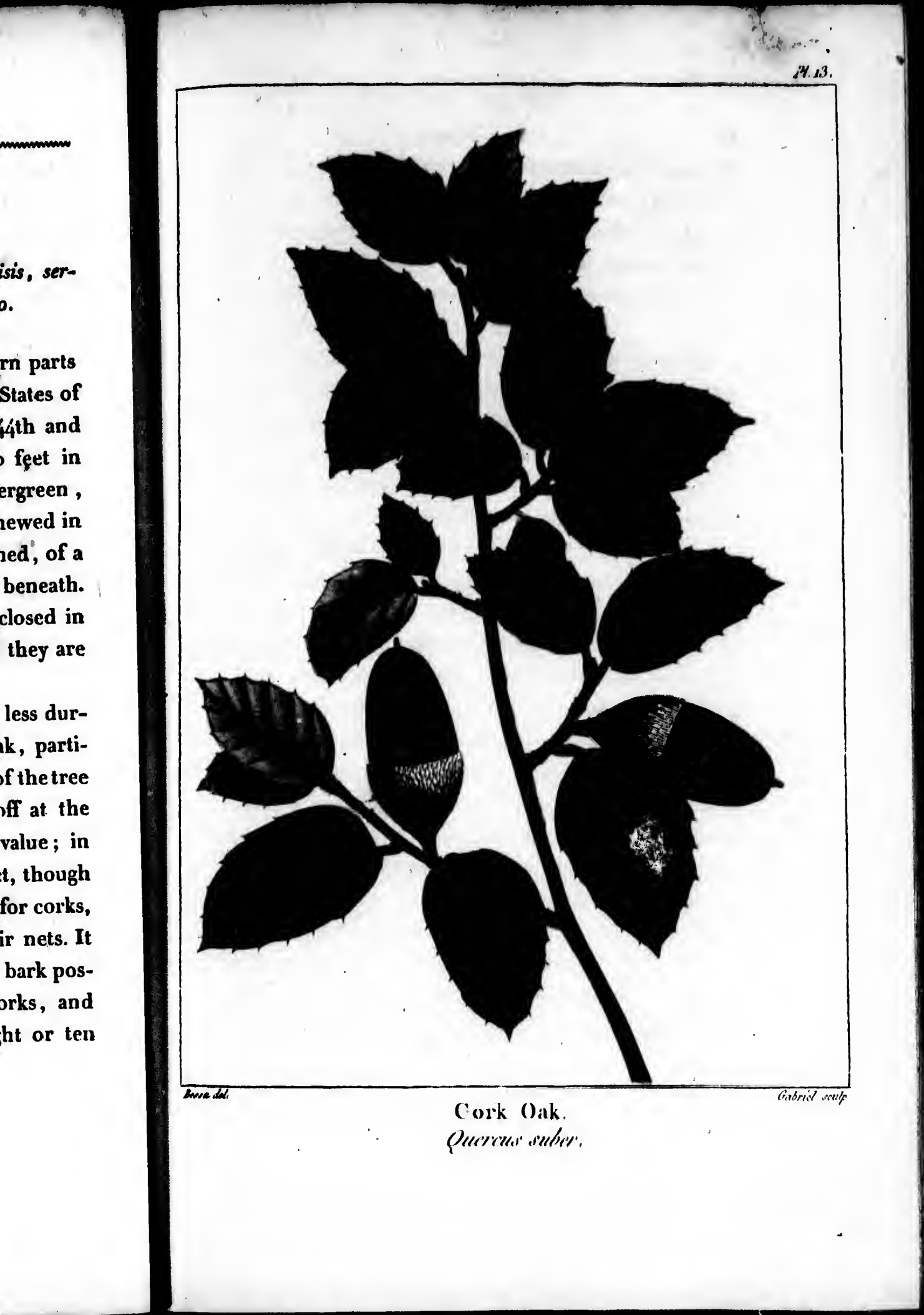


years. Its thickness is owing to the extraordinary swelling of the cellular integument. It is better fitted than any other substance for the use to which it is appropriated, as its elasticity exactly adapts it to the neck of the bottle, and its impenetrable struclure refuses admission to the fluid.

July and August are the seasons for gathering it. For this purpose two opposite longitudinal incisions are made through the whiole length of the trunk, and two others, transverse to the first, at the extremities; the bark is then detached by inserting a hatchet-handle shaped like a wedge. Great care must be taken not to wound the alburnum, as the bark is never renewed upon the injured parts. After being scraped, the bark is heated on its conver side, and laden with stones, to flatten it and render it easier of transportation. In Catalonia it is cut into pieces and boiled to improve its quality. Its excellence consists in being compact, supple and elastic and it should be from 15 to 20 lines thick.

The cork produced in France may be reckoned at 17 or 18,000 quintals, and when the sheets are smooth and even each quintal afiords 7,000 or 7,500 corks 18 lines long. The common price is a dollar and 70 cents a thousand, of which 50 cents must be allowed for the expense of making: It is computed that 110 or $1 \mathrm{~s} 5$ millions of corks are annually consumed in France.

This tree would be an important acquisition to the United States, and would grow wherever the Live Oak 
subsisto. The soil of the pine barrens is in general too meager to sustain its vegetation; the bed of regetable mould is in many places 80 thin, and the sand beneath $s 0$ homogeneous, that the roots of the Pines, instead of shooting downward, fold themselves back, as if nepelled by a solid rock.

Both public and private interest requires the inhabitants of the Southern coast, and especially of the neighbouring islands, to rear the Cork Oak about their plantations and in places that are unfit for the cultivation of cotton. It should also be introduced into West Tennessee, and with the nore reason as the Vine may be cultivated there with success.

As the young stocks are injured by transplanting, they should be permanently fixed the second or third year. To favour their growth, the earth should be loosened about the roots two or three times a year; and to render them tall and well-shaped, the lower branches should be cut even with the trunk. Their vegetation is in this manner strengthened and the bark improved; without farther attention they will continue to afford a valuable product during two or three centuries.

This tree has great advantages over several others which would likewise flourish in the same parts of the United States, such as the Olive and the White Mulherry. To fit their produce for consumption, particularly that of the Mulberry, requires complicated processes, which can be performed with adrantage only in 
populous countries. Hence the attempts made 70 or 80 years ago in Georgia to introduce the rearing of silkworms proved abortive; and the old White Mulberry Trees that still remain are monuments of that ill-culculated speculation. The bark of the Cork Oak, on the contrary, might be transported to the Northern States, or made into corks upon the spot by a simple operation performed by a single person with instruments of which the price does not exceed two or three dollars.

PLATE XiII.

1 branch with leaves and fruit of the natural size.

lanting, or third be loos$;$; and to branches station is nproved ; , afford a al others rts of the. hite Mul, particud procese only in

I. 


\section{WILLOW OAK.}

Quencus phenlos. Q. foluis lineari-lanceolatis, integerrimis, glabris, apice setaceo-acuminatis, junioribus dentatis lobatispe; cupuld scutellatd; glande subrotundd, minima.

THus species, which is remarkable for its foliage, makes its first appearance in the environs of Philadelphia; but it is more common and of a larger size in Virginia, the Carolinas and Georgia, where the milder temperature of the winter is evidently favourable to its growth. It is seen, however, only in the maritime parts of those States, and is a siranger to the inland districts, where the surface is mountainous and the climate more severe. From the analogy of soil and climate it is probably found in Lower Louisiana, but I have never observed it beyond the Alleghanies in Kentucky and Tennessee.

The Willow Oak commonly grows in cool moist places, and, with the Tupelo, the Small Magnolia, the Red-flowering Maple, the Red Bay and the Water Oak, it borders the swamps in the lower part of the Southern States. In these situations it attains its greatest expansion, which is 50 or 60 feet in height and from 20 to 24 inches in diameter. 'The trunk, even at an advanced age, is covered with a smooth bark, remarkable for the thickness of its cellular integument. The leaves are 2 or 3 


$$
\text { 放- }
$$




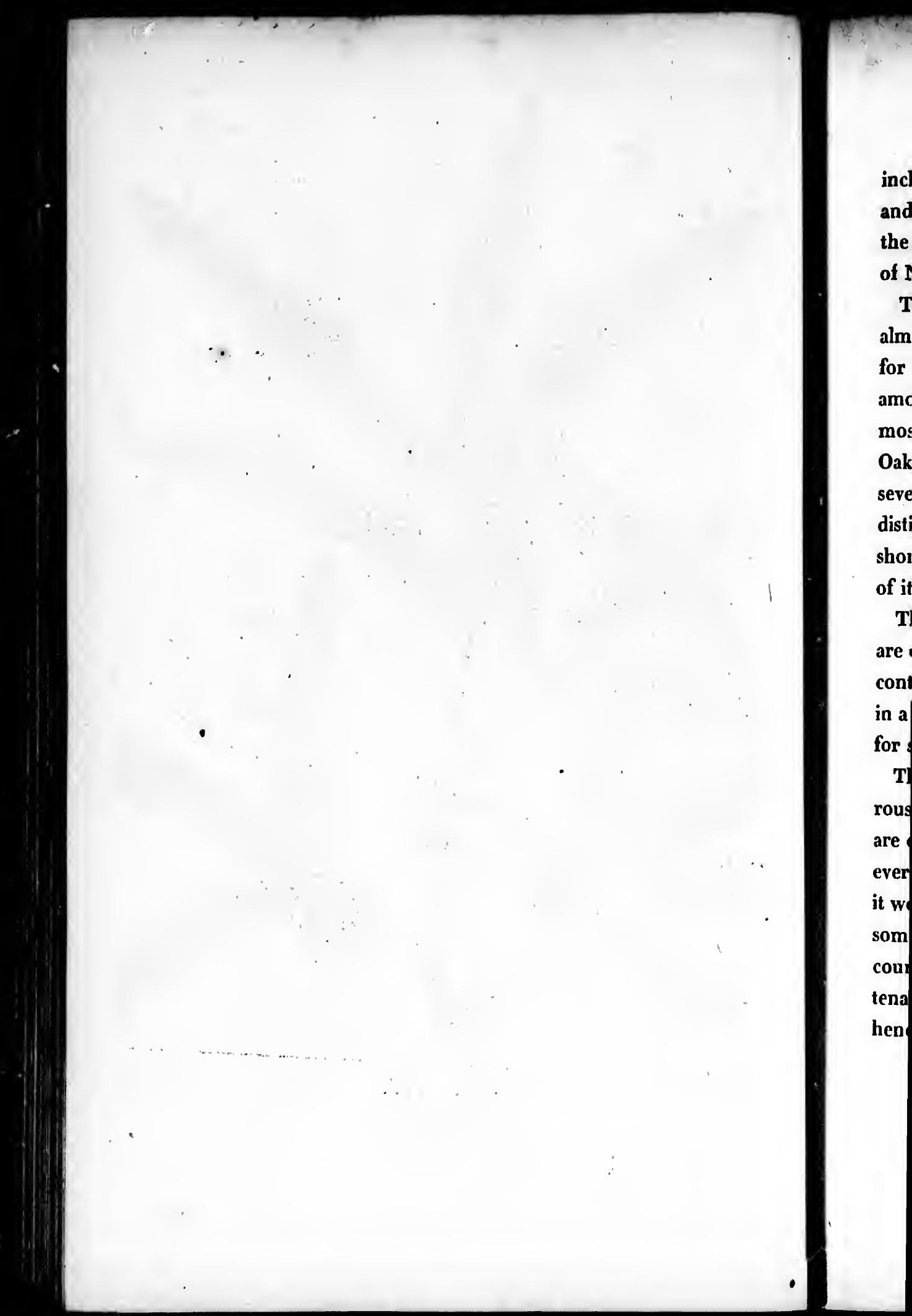


inches long, of a light green; smooth, narrow, entire, and similar to those of the Willow, whence is derived the name of Willow Oak, which is used in every part of North America where the tree is known.

Though the Willow Oak, as I have just observed, is almost always seen in moist grounds, by an' exception for which it is difficult to account it is sometimes found among the Live Oaks, near the sea, in the driest and most sandy soils. At a distance it resembles the Live Oak in its shape, and in its foliage which persists during several years; but on a closer examination it is easily distinguished by the form of its leaves, which are shorter and much narrower, and by the porous texture of its wood.

The fruit of this species is rarely abundant; the acorns are of a dark brown colour, small, round, bitter, and contained in shallow cups lightly coated with scales : kept in a cool place they preserve the faculty of germination for several months.

The wood is reddish and coarse-grained. It is too porous to contain wine or spirituous liquor, and its staves are classed with those of Red Oak. The quantity, however, is small, as the tree is so little multiplied that alone it would not supply the consumption for two years. In some of the lower parts of Virginia, particularly in the county of York, it is found to possess great strength and tenacity, and to split less easily than the White Oak; hence, after being thoroughly seasoned, it is employed 
for the felloes of wheels. These are the only uses to which it seems adapted, and for these it is less proper than the Post Oak and White Ash. On several plantations near Augusta in Georgia the fences are made partly of Willow Oak, which lasts only eight or nine years. As fuel, it is sold at the lowest price.

PLATE XIV.

1 branch with leaves and fruit of the natural size. 
uses to proper plantale partly ears. As

ize. 


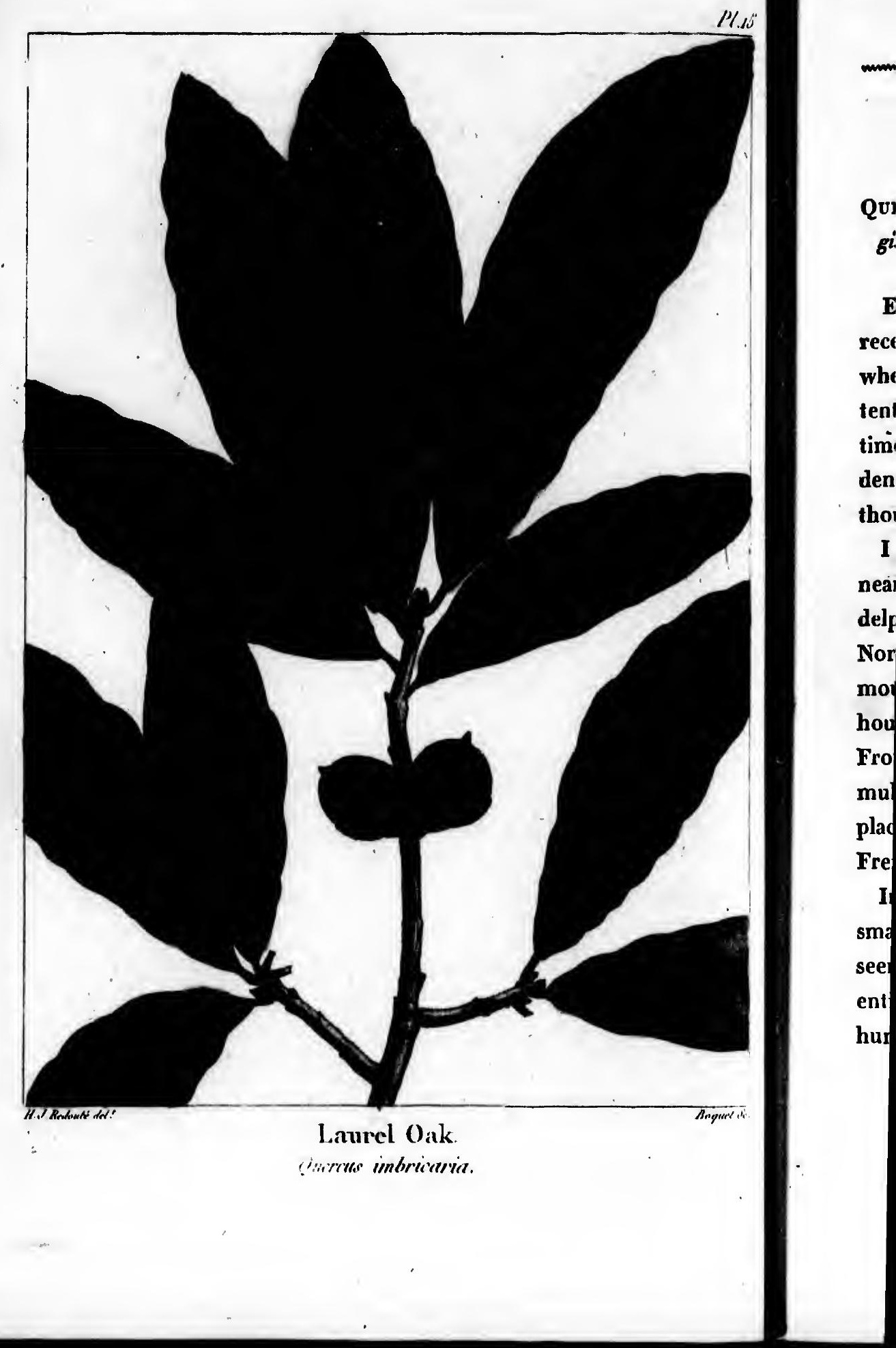




\section{LAUREL OAK.}

Quencus imnricaria. Q. foliis subsessilibus, ovali-oblongis, acutis, integerrimis, nitidis; glande subhemispharicd.

EAST of the Alleghanies this species is rare, and has received no specific name; west of the mountains, where it is more multiplied and has attracted more attention, it is called Jack Oak, Black Jack Oak, and sometimes, from the form of its leaves, Laurel Oak. The last denomination I have preserved as the most appropriate, though perhaps it is less common than the first.

I observed this tree for the first time in Pennsylvania near Bedford on the Juniata, upon the road from Philadelphia to Pittsburgh, and it does not exist in the more Northern States. I found it abundant only beyond the mountains, and particularly near Washington Courthouse and in some parts of Kentucky and Tennessee. From my father's observations it appears to be more multiplied in the country of the Illinois than in the places I have just mentioned, and it is called by the French Chêne à lattes, Lath Oak.

In the western parts of Pennsylvania and Virginia, small lawns, covered only with tall grass, are frequently seen in the forests, around which the Laurel Oak forms entire groves : insulated stocks are also found in cool hurnid situations. It is probably from its flourishing in 
open exposures that it is most abundant in the country of the Illinois, which consists of immeasurable savannas stretching in every direction, to which the forests bear no sensible proportion.

The Laurel Oak is 40 or 50 feet high, and 12 or 15 inches in diameter. Its trunk, even when old, is clad in a smooth bark, and, for three fourths of its height, is laden with branches. It has an uncouth form when bared. in the winter, but is beautiful in the summer when clad in its thick tufted foliage. The leaves are long, lanceolate; entire', and of a light shining green.

The wood is hard and heavy, though its pores are open. As the trunk is branchy and often crooked, it is considered, wherever I have observed it, as fit only for fuel; but my father, who first described it, says that the French of Illinois use it for shingles. Probably in that region it attains much greater dimensions; but in my opinion the want of better species only can account for its use. Its wood is inferior to that of the Willow Oak, which it nearly resembles.

This tree has no merit but its singular foliage, and it deserves the attention only of amateurs desirous of adorning their rural retreats with a variety of exotic trees.

\section{PLATE XV.}

A branch with leaves and fruit of the natural size. 
ountry

ivannas

sts bear

2 or 15 clad in ight, is n bared. ien clad ceolate; *it

ores are ed, it is only for ays that sably in but in account Willow

, and it rous of ff exotic

2. 


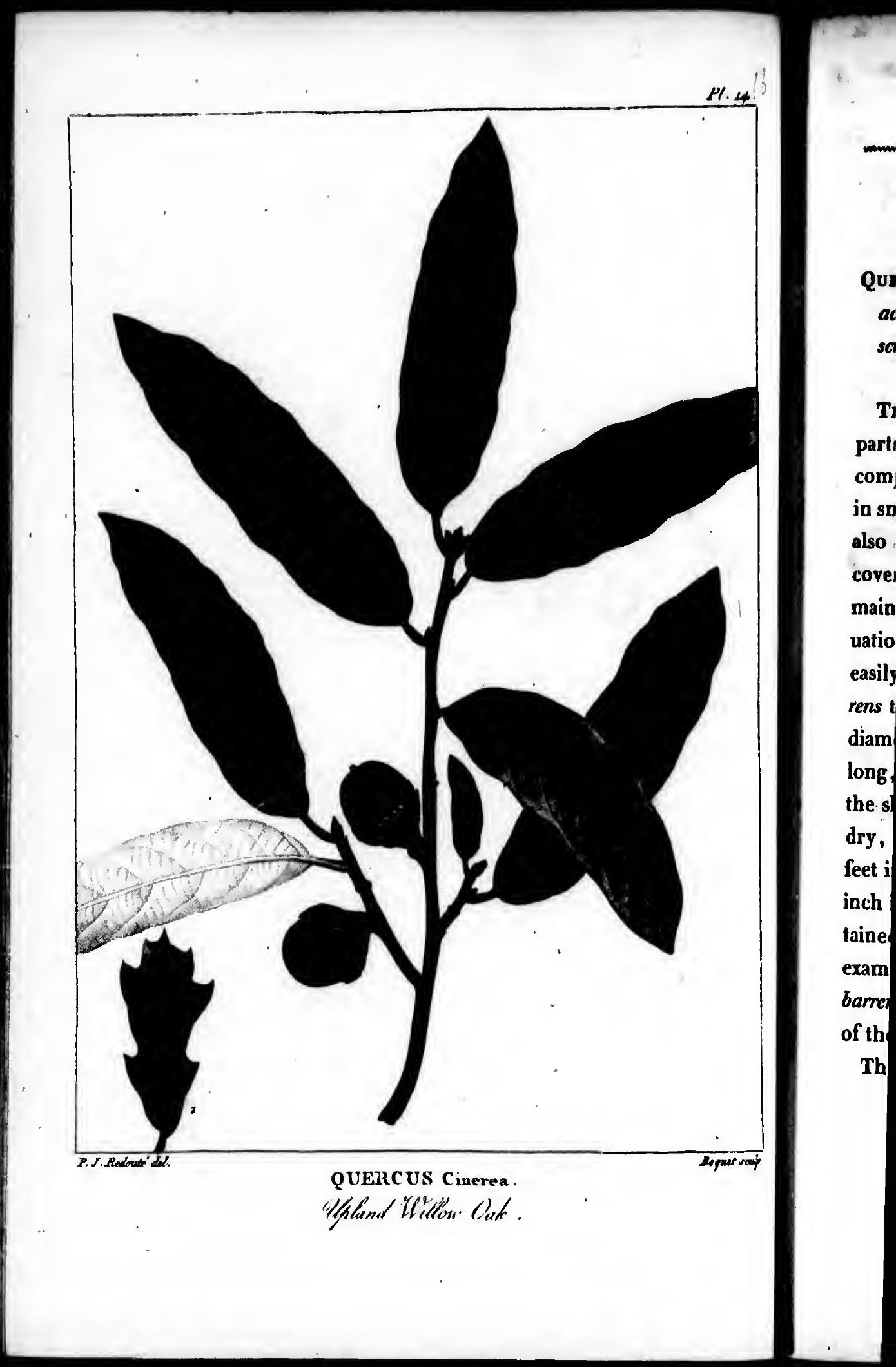




\section{UPLAND WILLOW OAK.}

Qurncus cinzres. Q. foliis petiolatis, lanceolato-oblongis, acuitis, integerrimis, subtus cinereo-pubescentibus; cupuld scutellatd; glande subhemispharicd.

Trz Upland Willow Oak is confined to the maritime parts of the Southern States. It is little multiplied in comparison with many other species, and is dispersed in small groups in the forests of White Pine. It is found also upon the sea-shore, and upon the islands where it covers tracts of several acres still more barren than the main. But the stocks which grow in these different situations are so different in appearance that they might easily be mistaken for distinct species : in the pine-barrens they are 18 or 20 feet high, and 4 or 5 inches in diameter, with the leaves entire, 2 inches and $a$ half long, and whitish underneath; on the islands and on the shore of the Continent, where the soil is extremely dry, as near Wilmington, N. C., they are only 3 or 4 feet in height, and the leaves are denticulated, are an inch in length, and persist for two years. I have ascertained that both varieties belong to the same species, by examining the sprouts of the larger stocks in the pinebarrens, of which the foliage is perfectly similar to that of the smaller ones on the shore.

The Upland Willow Oak is one of the abject trees 
that succeed the Pines on lands which have been cleared for cultivation and abandoned on account of their sterility. In these places, as in the pine-barrens, it is 20 feet in stature, and its trunk, crooked and covered wilh a thick bark, begins at a third of this height to divide itself by numerous ramifications. In the spting it is distinguished at a distance by the reddish colour of its leaves and male aments. The acorns, which are contained in shallow cups, are round and blackish, with the base of a bright rose colour when freshly exposed. It is rare to meet with a tree which yields a quart of fruit.

The bark of this species, like that of the Black Oak, affords a beautiful yellow dye; but the tree is so small and so little multiplied that it is of no utility in this respect, nor even for fuel.

The Quercus nana of Willdenow is certainly the smaller variety of this species.

\section{PIATE XVI:}

A branch with leapes and fruit of the natural sire. Fig. I, $A$ leaf of the smaller variety of the natural size. 



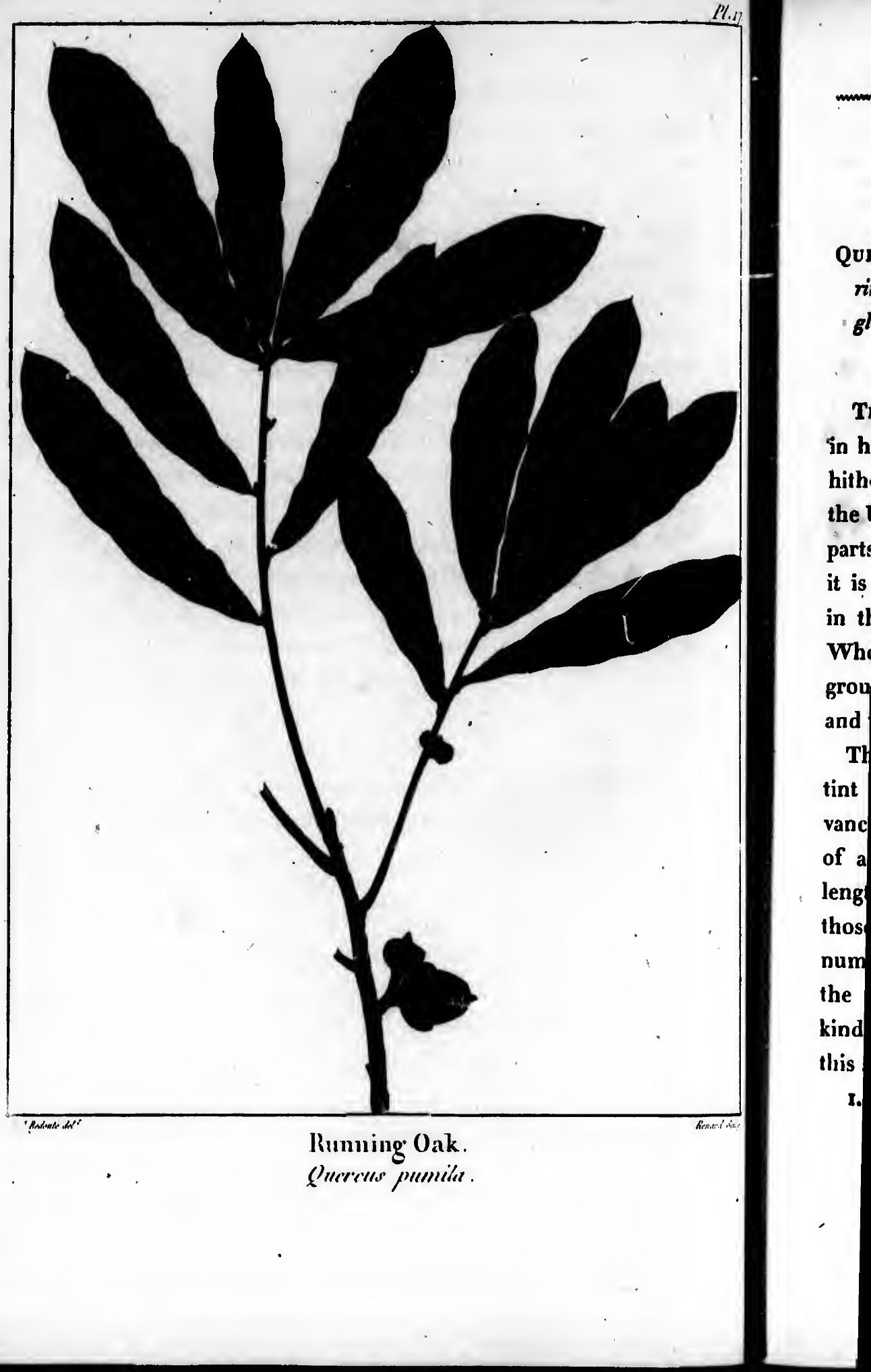




\section{RUNNING OAK.}

Quencus pumila. Q. foliis deciduis, lanceolatis, integerrimis, basi attenuatis, apice dilatatis; cupuld scutellatd; glande subhemispharicd.

Quercus sericea, WILLD.

Tuss species, which is rarely more than 20 inches in height and a lines in diameter, is the smallest Oak hitherto discovered in the Old or the New World. Like the Upland Willow Oak, it is confined to the maritime parts of the Carolinas, Georgia and the Floridas, where it is called Running Oak. It springs with that species in the pine-barrens, amid the numerous varieties of Whortleberry and other plants which overspread the ground wherever there is a little moisture in the soil and the layer of vegetable mould is a few inches thick.

The leaves of this dwarfish shrub are of a reddish tint in the spring, and turn green as the season advances. When fully developed they are entire, smooth, of an elongated oval shape, and about 2 inches in length. The acorns are small, round, and similar to those of the Willow and Water Oaks : they are few in number, because the stem is burnt to the surface of the ground almost every spring, by the fire which is kindled in the forests to consume the dead grass; as this species belongs to the division whose fructification

I. 
is biennial, the acorns are destroyed before they arrive at maturity.

My own observations, and those of Messrs. Bosc and Delille, distinguished botanists who resided several years in the Southern part of the United States, have led me to consider the Running Oak as a distinct species and not as a variety of the Willow Oak, as my father has treated it in his monography of this important genus. It is hardly necessary to remark that from its size it can be interesting only to botanists.

\section{PLATE XVII.}

A branch with leaves and fruit of the natural size. 



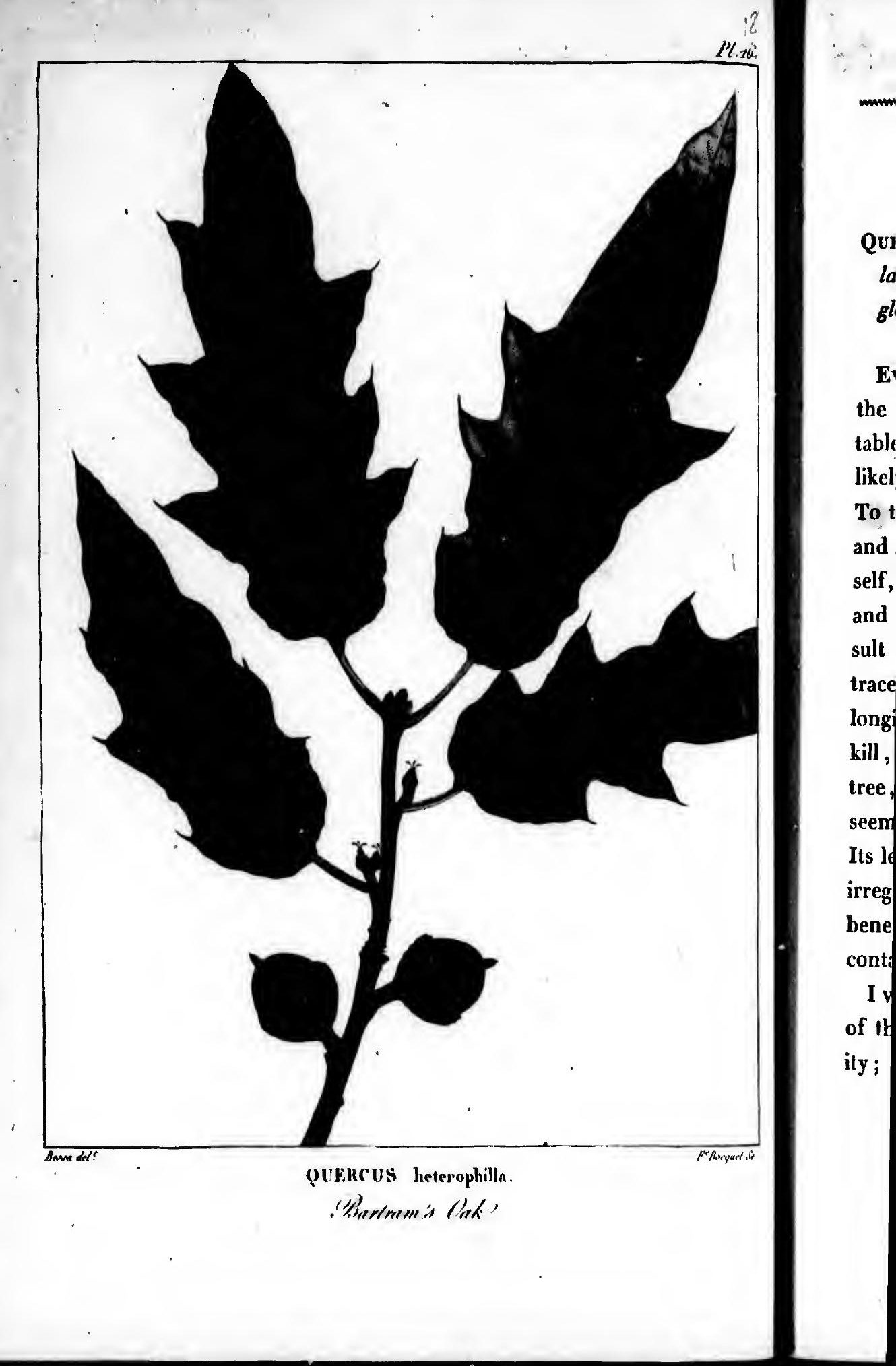




\section{BARTRAM OAK.}

Qurrcus hetrrophyLd. Q. foliis longe petiolatis, ovatolanceolatis, integris vel incequaliter dentatis; glande subglobosá.

Every botanist who has visited different regions of the globe must have remarked certain species of vegetables which are so little multiplied that they seem likely at no distant period to disappear from the earth. To this class belongs the Bartram Oak. Several English and American naturalists who, like my father and myself, have spent years in exploring the United States, and who have obligingly communicated to us the result of their observations, have, like us, found no traces of this species except a single stock in a field belonging to Mr. Bartram, on the banks of the Schuylkill, 4 miles from Philadelphia. This is a flourishing tree, 3o feet in height and 12 inches in diameter, and seems formed to attain a much greater developement. Its leaves are of an elongated oval form, coarsely and irregularly toothed, smooth above, and of a dark green beneath. The acorns are round, of a middle size, and contained in shallow cups lightly covered with scales.

I was at first disposed to consider this tree as a variety of the Laurel Oak, to which it bears the greatest affinity; but the leaves of that species are never indented, 
76

batran OAz.

and not a stock of it exists within a hundred miles of Philadelphia.

Several young plants, which I received from $\mathrm{Mr}$. Bartram himself, have been placed in our public gardens to insure the preservation of the species.

\section{PLATE XVIII.}

A branch with leaves and fruit of the natural size. 

II:

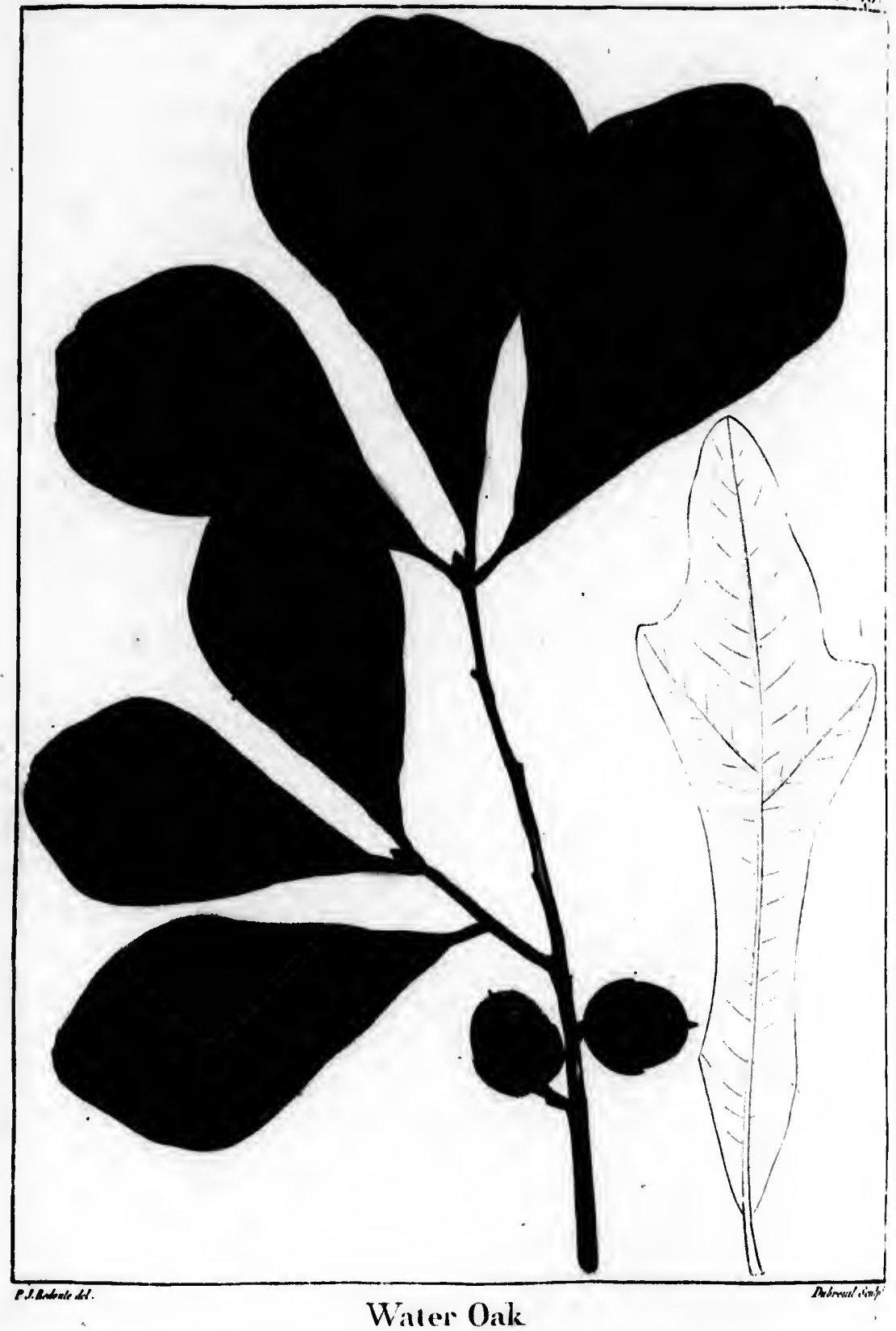

Qv

si

$n$

I

nea

in 1

part

Unı

foul

accc

in $t]$

Oak

or 1

are

and

ang

fall

Car

or

whi

that

fror

bee

and

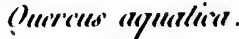




\section{WATER OAK.}

Quercus aquatica. Q. foliis obovali-cuneatih, basi acitis, summitate subintegris, variève trilobis, glabris; cupuld modice craterata; glande subglobosd.

THIs species tirst attracted my attention in the forests near Richmond in Virginia ; it becomes more common in proceeding southward, and abounds in the lower part of the Carolinas and Georgia, and in East Florida. Under the name of Water Oak it is sometimes confounded with the Willow Oak, by which it is always accompanied in the ponds and narrow swamps enclosed in the pine-barrens. It is inferior in size to the Willow Oak, and rarely exceeds 40 or 45 feet in height and 12 or 18 inches in diameter. On full-grown trees the leaves are smooth, shining, and heart-shaped - or broad and rounded at the summit and terminated in an acute angle at the base. In the severe climate of Virginia they fall with the first frost, but on the sea-shore of the Carolinas, Georgia and Florida, they persist during two or three years. There is no Oak in the United States of which the foliage is so variable and so different from that of the tree, on the young stocks and on the sprouts from an old trunk or from the base of a limb that has been lopped : the leaves are eommonly oval and deeply and irregularly toothed. 
The acorns, which are contained in shallow, slightly scaly cups, are brown, small, and extremely bitter; the largest tree rarely yields more than five or six quarts. Like those of the Willow Oak, when kept cool they preserve their fecundity for several months.

The bark upon the oldest trunks is smooth and very slightly furrowed; it is little used in tanning, either because it is inferior to that of the Spanish Oak, or because the tree is less abundant.

The wood is very tough, but less durable and less esteemed by carpenters and wheel-wrights than that of the White Oak and Chesnut White Oak.

As this species is destitute of interest, it will probably become extinct like many others which are rapidly diminishing. In France it would flourish only in the southern departments.

PLATE Xíx.

$A$ branch with leaves and fruit of the natural size. 



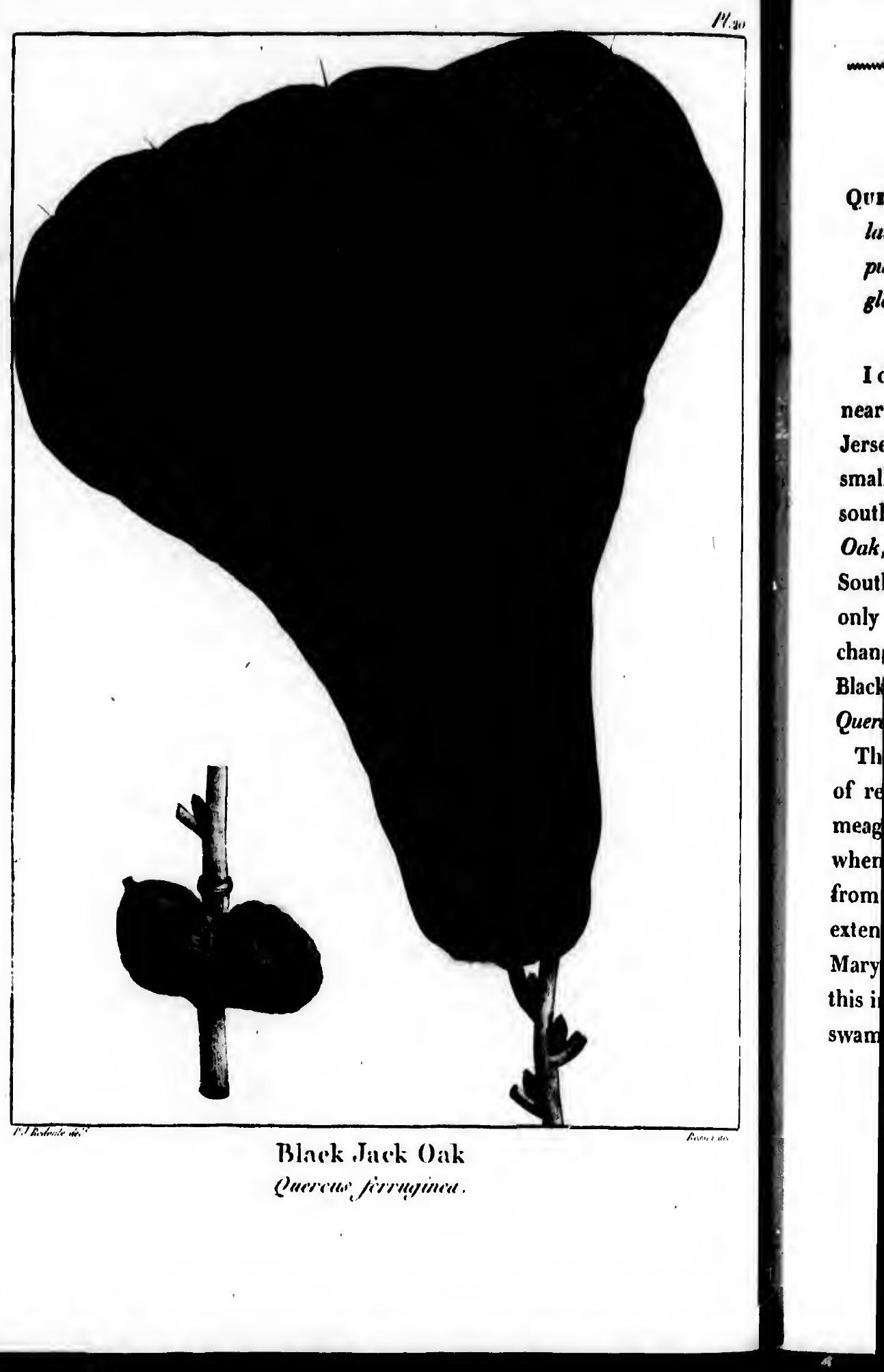




\section{BLACK JACK OAK.}

Quencus rennuginea. Q. foliis coriaceis, summitate dilutatis, retuso-subtrilobis, basi retusis, subtus rubiginosopulverulentis; cupuld turbinatd, squamis oblusis, scariosis; glande brevi ovata.

Quercus nigra, WILLD.

I observed this species for the first time in the forests near Allenstown and Cranbury, small towns of New Jersey, about 60 miles east of Philadelphia; but it is smaller and less multiplied in this place than farther south. In New Jersey and Philadelphia it is called Barrens Oak, and Black Jack Oak in Maryland and the more Southern States. I have adopted the last of these names only because it is the most generally used, and have changed the specific epithet nigra, because the name of Black Oak is appropriated in the United States to the Quercus tinctoria.

This species is commonly found upon soils composed of red argillaceous sand mingled with gravel, and so meager as to be totally exhausted by tive or six crops; when they are thought worthy of cultivation. Unhappily from Baltimore to the borders of North Carolina, an extent of four or five hundred miles, the greater part of Maryland and Virginia consists of this soil. The whole of this interval, with the exception of the vallies and the swamps with their surrounding acclivities, is covered 
with forests impoverished by fire and by the cattle that subsist in them during a great part of the year. They are composed principally of Yellow Pine, Post Oak, Black Jack Oak, Black Oak and Scarlet Oak. In the Carolinas and Georgia, where the soil gradually improves in retiring from the shore towards the mountains, the same tree forms a band 15 or 20 miles wide, between the pine-barrens and the forests of a more generous growth. In Kentucky and Tennessee the Black Jack Oak is seen only in the savannas, where it is widely diffused, and where, preserved by the thickness of its bark and its insulated position, it survives the conflagrations that almost every year consume the grass; the fire, udriven forward by the wind, has only time to devour its foliage. In the pine-barrens it grows chiefly on the edges of the branchswamps, where the soil is a little stronger than is necessary for the Pines. With the Upland Willow Oak and the Scrub Oak it possesses itself of the pine lands that have been cleared for cultivation and abandoned on account of their sterility; and in these situations it is larger than in the forests.

The Black Jack Oak is sometimes 30 feet high and 8 or ro inches in dameter, but commonly does not exceed half these dimensions. Its trunk is generally crooked, and is covered with a very hard, thick and deeply furrowed bark, of which the epidermis is nearly black, and the cellular integument of a dull red. The summit is spacious even in the midst of the woods. The leaves are yellow- 
ish, and somewhat downy at their unfolding in the spring ; when fully expanded they are of a dark green above, rusty beneath, thick, coriaceous, and dilated towards the summit like a pear. In the autumn they turn reddish, and fall with the earliest frost.

The oldest trees bear only a few handfuls of accins, which are large, and half covered with very scaly cups.

When the stock is more than 8 inches in diameter, the wood is heavy and compact ; but coarse-grained and porous before it has reached this size. As it speedily decays when exposed to the weather, it is not used in the arts. It forms excellent fuel, and is sold at Philadelphia only one dollar a cord less than Hickory, while other kinds of wood are a third cheaper.

This species deserves the attention of amateurs in Europe, for the singularity of its foliage.

PLATE XX.

A branch with leaves and fruit of the natural size. 


\section{BEAR OAK.}

Quercus Banisteri. Q. foliis longe petiolatis, acutangulo. quinque-lobis, margine integris, subtus cinereis; cupuld subturbinatá; glande subglobosá.

Thus diminutive species is known in the Northern and Middle States by the names of Bear Oak, Black Scrub Oak and Dwarf Red Oak, of which the first is the most common in New Je'sey, where the shrub abounds. The latin specific name was given it in honour of Banister, an English writer, by whom it was first introduced to notice.

I do not remember to have seen the Bear Oak in the lower part of the Southern States; it is common in those of the North, and still more so, I believe, in New York, New Jersey and Pennsylvania. I have more particularly observed it at Fishkill, Katskill and Albany in New York, near Paramus in New Jersey, and on that part of the Alleghanies in Pennsylvania which is crossed by the road to Pittsburgh. It is never found insulated or mingled with other shrubs in the forests, but always in tracts of several hundred acres, which it covers almost exclusively : a few stocks of the Dwarf Chesnut Oak are often united with it.

The ordinary height of the Bear Oak is 3 or 4 feet ; but when arcidentally insulated, and nourished by a vein 
of
ust
wi
the
he
the
shr
I

lik

str

rar

a di

reg

bla

line

bra

for

hea

1

libl

dry

ada

Nev

tage

stre

to $h$

ado

be 
of more fertile soil, it sometimes equals 8 or 10 feet. It usually grows in compact masses, which are traversed with difficulty, though no higher than the waist. As the individuals which compose them are of an uniform height, they form so even a surface that at a distance the ground appears to be covered with grass instead of shrubs.

The trunk, which is numerously ramitied, is covered, like the branches, with a polished bark. It has more strength than would be supposed from its size, which is rarely more than an inch in diameter. The leaves are of a dark green on the upper surface; whitish beneath, and regularly divided into 3 or 5 lobes. The acorns are small, blackish, and longitudinally marked with a few reddish lines : they are so abundant as sometimes to cover the branches; the lowly stature of the shrub renders it easy for bears, deer and swine to reach them by lifting their heads or rising on their hinder feet.

The presence of this Oak is considered as an infallible index of a barren soil, and it is usually found on dry sandy land mingled with gravel. It is too small to be adapted to any use ; but near Goshen, on the road to New York, I observed an attempt to turn it to advantage, by planting it about the fields for the purpose of strengthening the fences.Though this experiment seemed to have failed, I believe the Bear Oak night be usefully adopted in the Northern States for bedges, which might be formed from 20 to 24 inches thick, by sowing the 
acorns in three parallel furrows. They would be perfected in a short time, would be agreeable to the eye, and probably would be sufticient to prevent the passage of horses and cows. Hedges of the European Thorn would doubtless be preferable; but they require a good soil and more labour than can at present be afforded in America : those that exist in the neighbourbood of Philadelphia are left in a condition which would give a very unfavourable opinion of the farmer on whose lands they were seen in the North of France.

As the Bear Oak grows on the most sterile soils, and resists the most intense cold and the most impetuous winds, perhaps it might serve to shelter the infancy of other more valuable trees in such exposures. The want of some such protection. is the greatest obstacle to the success of plantations on the downs, as I was told near the Hague upon the coast of Holland.

Proprietors of large estates, who are addicted to the chase, might find this species and the Dwarf Chesnut Oak convenient for copses; they would afford nourishment to the game during several months in the year, and would allow the sportsman a fair aim at the birds as they rose upon the wing.

PLATE XXI.

A branch with leaves and fruit of the natural size. 
be perthe eye, passage

a 'Thorn

e a good orded in of Philve a very sse lands oils, and npetuous nfancy of The want cle to the told near ed to the Chesnut nourishthe year, e birds as

size. 


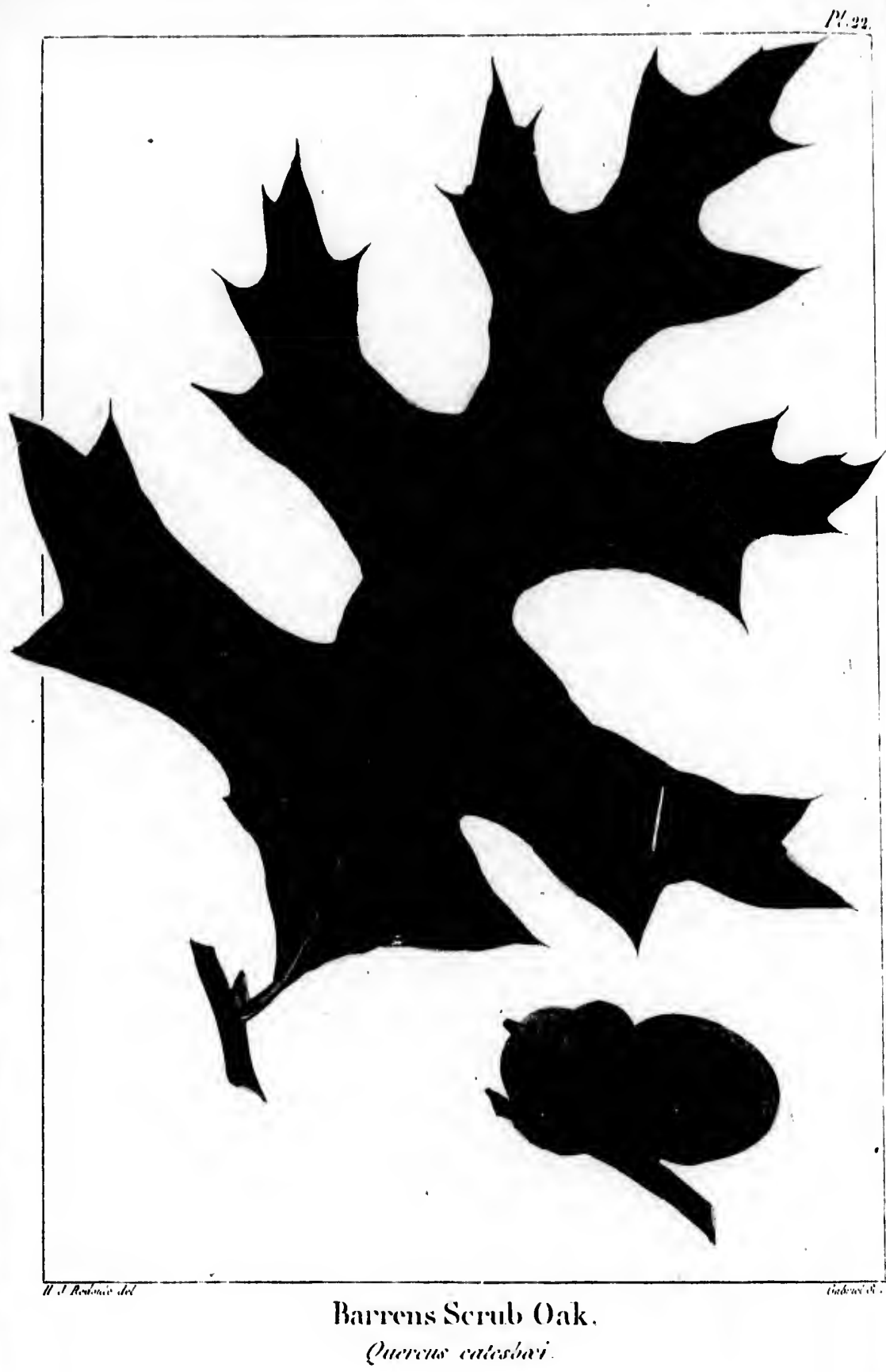

Qu
$p$
$j$
o

A

con

I fir

$35^{\circ}$

vege

whe

geta

pine

deri

Ir

Oak

tevil

it $\mathrm{ft}_{\mathrm{f}}$

the1

the

$\mathbf{T}$

larg

of $s$

port

to a

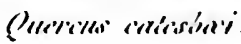




\section{5.}

\section{BARRENS SCRUB OAK.}

Quercus catesber. $Q$. foliis brevissime petiolatis, subpalmato-lobatis, lobis interdum subfalcatis; cupuld majuscula, squamis marginalibus introflexis; glande brevi ovatd.

According to my own observations this species is confined to the lower part of the Carolinas and Georgia. I first saw it a few miles south of Raleigh, N. C., latitude $35^{\circ} 40^{\circ}$. It grows in soils too meager to sustain any other vegetation, such as the vicinity of Wilmington, N. C., where the light moveable sand is wholly destitute of vegetable mould. It is the only species mulliplied in the pine-barrens, and from this circumstance it seems to have derived its name.

In traversing these forests I nowhere saw the Scrub Oak, more uniformly disseminated than between Fayetteville and Wilmington, an interval of 60 miles, where it forms nearly one tenth of the woods: the Pines themselves, throughout the barrens, are scatlered at the distance of 15 or 20 fect.

The foliage of this tree is open, and its leaves are large, smooth, thick and coriaceous towards the close of summer, deeply and irregularly lacinialed, and supported by short petioles. With the first frost they change to a dull red, and fall the ensuing montl. The acorns 
are pretty large, of a blackish colour, and partly covered with a fine grey dust, which is easily rubbed of between the fingers: they are contained in thick cups swollen towards the edge, with the upper scales bent inwards. The oldest trees alone are productive, and their fruit never exceeds a few handfuls.

In the winter it is difficult to distinguish the Scrub Oak from the Black Jack Oak, which it nearly resembles. Jike that, it is crooked, ramitied at the height of 2 or 3 fect, and covered with a thick, blackish, deeply furrowed bark : it is, besides, perfectly similar in the colour, texture and weight of its wood. At Wilmington the Scrub Oak is the best fuel, and is sold separately; but notwithstanding its abundance in this district it is insufficient for the supply of the inhabitants : its size alone would exclude it from use in the arts.

The general character of this tree forbids the hopes of advantage that might be conceived from its flourishing upon the most sterile soils.

PLATE XXII.

A branch with leaves and fruit of the natural size. 
y covered between swollen inwards. heir fruit

he Scrub esembles. ht of 2 or eeply furin the congton the ately ; but it is insufsize alone the hopes s flourishsize. 


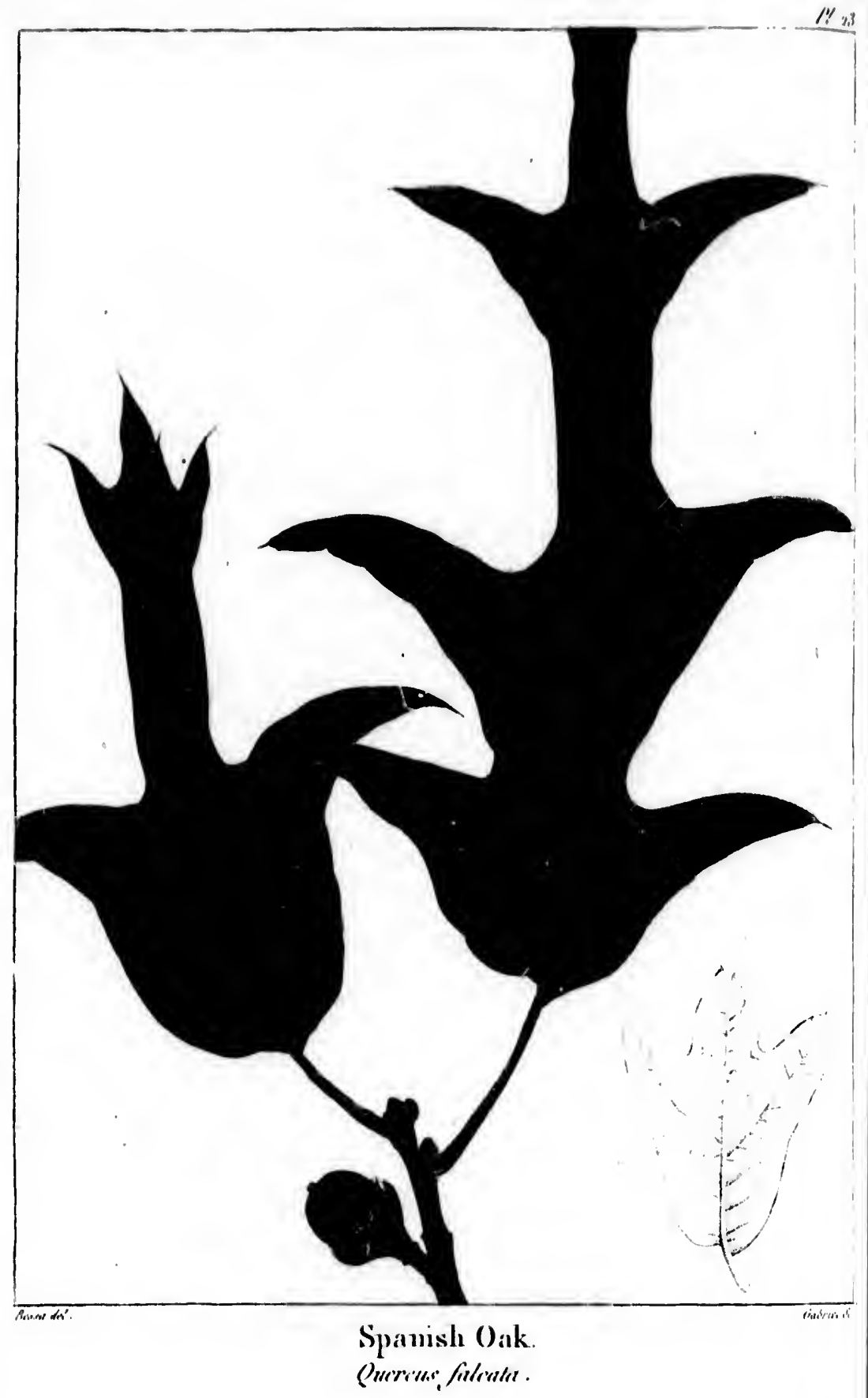

мииห:

Quen

lobe

crat

TiII

itself $i$

from 1

than ir quires exhibit stantly forests. the mo Delawa the na Georgis which I have be the rese velani $\mathrm{v}$ just or the inh: minatio Souther the grea Spanish ()ak

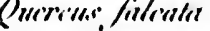




\section{SPANISH OAK.}

Quzrcus razcata. Q. folits longe petiolatis, subpalmatolobatis, subtus eximie tomentosis, lobis falcatis; cupula crateriformi; glande subglobosd.

Quercus elongata, WiLLv.

Turs species, like the Black Jack Oak, begins to show itself in New Jersey, near Allentown, about 60 miles from Philadelphia. But even at this distance it is smaller than in the immediate vicinity of the city, where it acquires its perfect developement, and where its leaves exhibit their appropriate form. Farther south it is constantly found among the most common trees in the forests. I have observed that it is less multiplied near the mountains, and in the country beyond them. In Delaware, Maryland and Virginia, it is known only by the name of Spanish Oak, and in the Carolinas and Georgia by that of Red Oak. In an old English work which I found in the library of Charleston, it is said to have been called Spanish Oak by the first settlers, from the resemblance of its leaves to those of the Quercus velani which grows in Spain. Whether this etymology is just or not, I am unable to say; but it is unknown to the inhabitants who have adopted the name. The denomination of Red Oak, which is used only in the more Southern States, was probably given it on account of the great analogy between its wood and that of the spe- 
cies thus called in the Northern and Middle States, where the Spanish Oak is much less common than in the South.

This tree is more than 80 feet in height, and 4 or 5 feet in diameter. Its leaves are very different on different individuals ; thus in New Jersey, where the tree is only 3o feet high and 4 or 5 inches thick, they are threelobed, except a few on the summit, and not falcated as on the large stocks in the Southern States. On young plants, and on the lower branches of the most vigorous stocks growing in moist and shaded situations, they are also trilobed; and on the upper limbs they are more acutely laciniated, with the sections more arching than those represented in the figure. This remarkable difference led my father to describe as a distinct species, under the name of Quercus triloba, the individuals whose foliage had not acquired its perfect form. Sometimes, on the sprouts of trees that have been felled, the leaves are deeply denticulated at right angles to the main rib. One of their constant characters is a thick down upon the lower side of the leaf and upon the young shoots to which they are attached.

The acorns are small, round, of a brown colour, and contained in slightly scaly shallow cups supported by peduncles one or two lines in length. They resemble those of the Bear Oak, and, like them, preserve for a long time the faculty of germination.

The bark upon the trunk is blackish and deeply fur- 
e States, than in nd 4 or 5 different ree is only are threeot falcated On young st vigorous is, they are y are more rching than kable differnct species, iduals whose Sometimes, d, the leaves he main rib. down upon ing shoots to colour, and supported by hey resemble preserve for a id deeply fur-

rowed, with a cellular iutegunent of miduling thickness. The wood is reddish and coarse-grained, with emply pores, and all the characteristic properties of the species known in commerce by the general name of Red Oak : hence its staves are fit only to contain melasses, salted provisions and dry goods. I have been told that in the West Indies the Red Oak staves from the Southern States, where this species abounds, are the most esteemed, from which it seems probable that its wood is belter than that of the Red, Scarlet and Black Oaks that furnish almost all the Red Oak staves from the Northern and Middle States : this superiority, however, is not sufficiently marked to occasion a difference in the price.

From its want of durability the Spanish Oak is less esteerned than the White Oak, the Post Oak, and other species of annual fructitication. It is rarely employed in building , and is used by cart-wrights only at Baltimore, where it is preferred to the White Oak for the felloes of large wheels.

'The principal merit of the Spanish Oak, which gives it a superiority over most other species of the United States, resides in its bark. This is preferred for tanning coarse leather, which it renders whiter and more supple; it is consecquently sold at Philadelphia and Wilmington a fourth dearer than that of the other Oaks : the leather is said to be improved by the addition of a small quantity of the bark of the Hemlock Spruce.

The Spanish Oak is adapted to the climate of the I. 
centre of France, if we may judge from its multiplication in the nurseries and in the gardens of amateurs. The stocks that have sprung from the acorns which I sent home during my residence in America bear as yet only three-lobed leaves, but they will become falcated at a maturer age.

From the inferiority of its wood, this species would not, in my opinion, deserve a place in our forests, though its bark should prove equal to that of the European Oak. But in the Southern States, when some species of trees are to be multiplied in preference to others, the Spanish Oak alone should be spared among the Red Oaks, as, besides its superiority in other respects, it has the advantage of flourishing on lands of a middling quality, such as compose a large part of that Section of the United States.

PLATE XXIII.

$A$ branch with leaves and fruit of the natural size. 



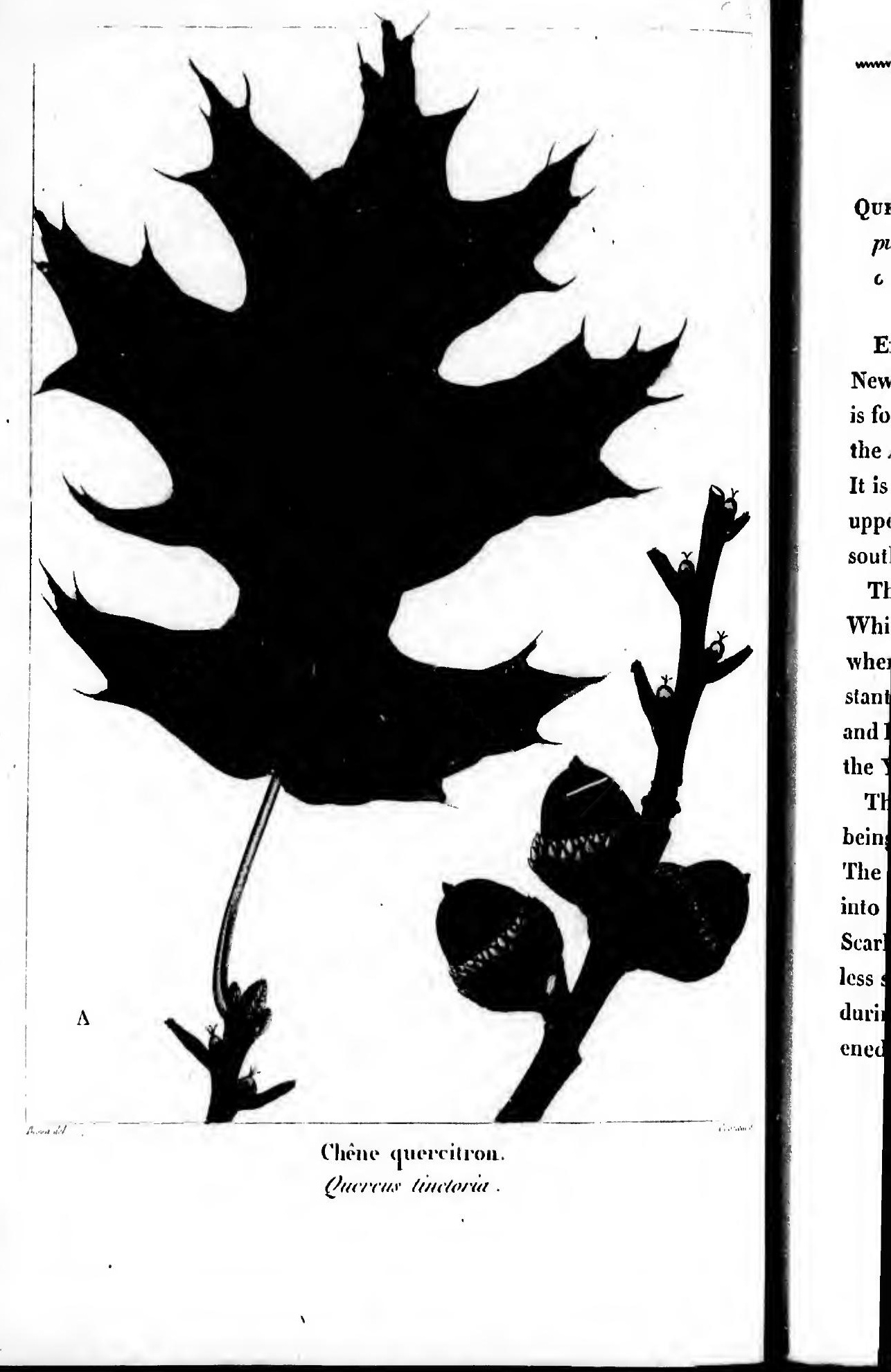




\section{1.}

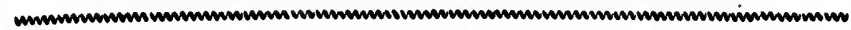

\section{BLACK OAK.}

Quencus Tinctoria. Q. foliis profunde sinuosis, subtus pulverulentis; cupula turbinata, squamosâ; glande brevi c $x t a$.

Except the District of Maine, the northern part of New Hampshire, Vermont and Tennessee, this species is found throughout the United States on both sides of the Alleghanies, and it is every where called Black Oak. It is more abundant in the Middle States, and in the upper part of the Carolinas and Georgia, than on the southern coast.

The Black Oak flourishes in a poorer soil than the White Oak. In Maryland and cerlain districts of Virginia, where the soil is lean, gravelly and uneven, it is constantly united in the forests with the Scarlet, Spanish and Post Oaks, and the Mockernut Hickory, with which the Yellow Pine is also frequently mingled.

This Clak is one of the loftiest trees of North Anerica, being 80 or 90 feet high and 4 or 5 feet in diameter. The leaves are large, deeply laciniated, and divided into four or five lobes : they resemble those of the Scarlet Oak, but have less deep and open sinuses, are less shining, of a doher green, and in the spring and during a part of the summer have their surface roughened with small glands which are sensible to the eye 
and to the touch. The same appearance is observed on the young shoots. I have remarked that the leaves of the young stocks change in the autumn to a dull red, and those of the old trees to yellow, beginning with the petiole.

The trunk is covered with a deeply furrowed bark of middling thickness, and always of a black or very deep brown colour, whence probably is derived the name of the tree. North-east of Pennsylvania the complexion of the bark is the only character by which it can be distinguished from the Red, Scarlet and Grey Oaks, when the leaves are fallen. Farther south this character is not sufficient to distinguish it from the Spanish Oak, whose bark is of the same colour, and recourse must be had to the buds, which, on the Black Oak, are longer, more acuminate, and more scaly. All doubt may be removed by chewing a bit of the cellular integument of each: that of the Black Oak is very bitter and gives a yellow tinge to the saliva, which is not the case with the other.

The wood is reddish and coarse-grained, with emply pores : it is, however, more esteemed for strength and durability than that of any other species of biennial fructification. At Philadelphia it is employed, for want of white oak, in building; and the farmers of the Northern States, by a miscalculating economy, substitute it in the place of the White Oak for fences.

As this species is abundant in the Northern and Middle States, it furnishes a large proportion of the 
observed leaves of dull red, ing with

d bark of very deep name of jexion of be distiniks, when cter is not ak, whose ist be had iger, more e removed of each: is a yellow the other. with emply rength and ennial frucor want of the Northsubstitute it thern and ion of the

Red Oak staves exported to the Colonies or employed at home to contain flower, salted provisions and melasses.

The bark is extensively used in tanning, as it is easily procured and is rich in tannin. The only inconvenience which attends it is imparting a yellow colour to the leather, whieh must be discharged by a particular process, to prevent its staining the stockings : it is a great error to assert that this colour augments its value

From the cellular integument of the Black Oak is obtained the quercitron, of which great use is made in dying wool, silk and paper-hangings. According to several authors tho have written on this subject, and among others Dr. Bancroft, to whom we are indebted for this disccuvery, one part of quercition yields as much colouring matter as eight or ten parts of woad. The decoction is of a brownish yellow, which is ren dered deeper by alkali, and lighter by acids. A solution of alum causes a small portion of the colouring matter to fall in a deep yellow precipitate; solutions of tin afford a more abundant precipitate of a bright hue.

To dye wool, it is sulficient to boil the quercitron with an equal weight of alum : in dipping the stuff, the deepest shade is given tirst, and afterwards the straw-colour : to animate the tint the stuff may be passed, in coming out of the dye, through water whitened with a little wrished chalk. A brighter colour is obtained by means of a solution of tin. Quercitron may be substituted for woad, in giving all the shades of yellow to silk : the pro- 
portion is one part by weight to twelve parts of silk. In the advertisements of Philadelphia for February 1808 , this substance is rated at 40 dollars a ton, and from that city chiefly it is exported to Europe.

Though the wood of the Black Oak is of a better qua. lity than that of the Scarlet, Spanish, Red, Pin, Grey, Willow and Water Oaks, which are all comprehended under the name of Red Oak, it is much inferior to that of the European Oak. But its stature, the rapidity of its growth in the coldest climates and the most indifferent soils, and, above all, the value of its bark in dying, recommend it powerfully to the notice of European forester's.

\section{PLATE XXIV.}

$A$ leaf of the natural size.

Note. The small branch with the acorns belongs to the Scarlet Oak. 
f silk. In

ary 1808 , rom that

etter qua-

in, Grey, rehended or to that lity of its ndifferent lying, reopean foongs to the 


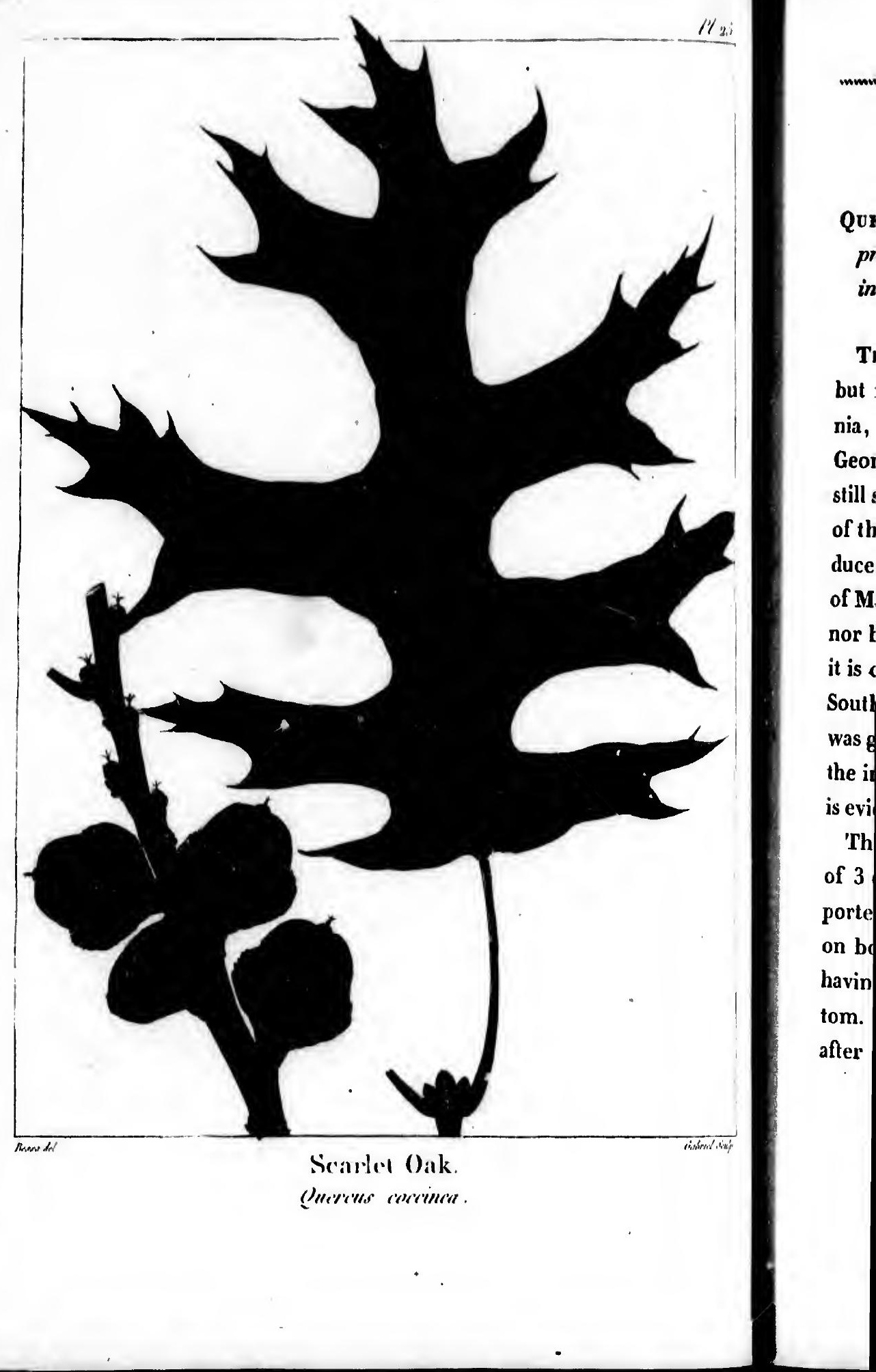




\section{5.}

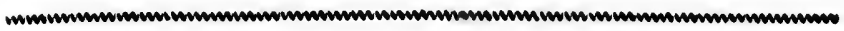

\section{SCARLET OAK.}

Quencus coccinen. Q. foliis longe petiolatis, oblongis, profunde sinuatis, glabris; lobis denlatis, acutis; cupuld insigniter squamosa; glande brevi ovald.

The Scarlet Oak is first seen in the vicinity of Boston, but it is less multiplied than in New Jersey, Pennsylvania, Virginia, and the upper part of the Carolinas and Georgia, where it forms a part of the forests that are still standing : it is much less common in the lower parts of these States, which, as I have already observed, produce nothing but Pines. I have not seen it in the district of Maine, the States of New Hampshire and Vermont, nor beyond Utica in Gennessee. In the Northern States it is confounded with the Red Oak, and in those of the South, with the Spanish Oak. The name of Scarlet Oak was given it by my father, and, though not in use among the inhabitants, it will probably be adopted, as the tree is evidently a distinct species.

This is a vegetable of more than 80 feet in height and of 3 or 4 feet in diameter. The leaves, which are supported by long petioles, are of a beautiful green, shining on both sides, and laciniated in a remarkable manner, having usually four deep sinuses very broad at the bottom. They begin to change with the first cold, and, after several successive frosts, turn to a bright red, in- 
stead of a dull hue like those of the Red Oak. At this season the singular colour of the foliage forms a striking contrast with that of the surrounding trees, and is itself a sufficient inducement to cultivate the tree for ornament.

The acorns are large, somewhat elongated, similarly rounded at both ends, and half covered with scaly cups. As this fruit varies in size with the quality of the soil, it is diflicult to distinguish it from that of the Black Oak; the only constant difference is in the kernel, which is yellowish in the Black Oak, and white in the species we are considering.

The wood of the Scarlet Oak is reddish and coarsegrained, with open pores. As it decays much more rapidly than the White Oak, it is employed by the builder and wheel-wright only from necessity or economy. It is poor fuel, and is used principally for staves : in the Middle States, a large part of the Red Oak staves are furnished by this species.

The bark, though very thick and generally employed in tanning, is in no respect preferable to that of the Grey and Red Oaks.

That this tree will flourish in France, is shown by an example at Rambouillet, where it makes part of a beautiful plantation 45 fect in height, formed, in 1786 , of species sent home by my father soon after his arrival in the United States. It is to be regretted that so fine a tree, which is so well adapted to our soil, should afford 
SCARLET OAK.

such indifferent wood that we cannot recommend its introduction into the forests of Europe, nor its preservation in those of the United States.

\section{PLATE XXV:}

1 leaf of the natural size:

Note. The acoms in this plate belong to the Black Oak. ty of the he Black kernel, te in the

d coarsenore rapte builder omy. It is

$s:$ in the staves are employed hat of the shown by part of a 1 , in 1786 , - his arrival at so fine a ould afford

I. 


\section{GREY OAK.}

Quercus boreatis. $Q$. foliis sinuatis, glabris, sinubus subacutis; cupulá subscutellatá; glande turgide ovata.

The Grey Oak appears, by my father's notes, to be found farther north than any other species in America ; in returning from Hudson's Bay he saw it on the $\mathrm{St}$. Lawrence between Quebec and Malabaie, in latitude $47^{\circ} 50^{\prime}$. Under that parallel, and near Halifax in Nova Scotia, where I first observed it, it is not more than 40 feet high; and, though the bloom is annual, the winter is so rigorous and so long that the fruit is said to be matured only unce in three or four years. Three degrees farther south in Maine and New Hampshire, and on the shores of Lake Champlain in Vermont, it is more multiplied, and is 50 or 60 feet in height and 18 inches in diameter. It is called by the inhabitants Grey Oak, but it has been confounded by botanists with the Red Oak, to which it bears a close analogy in its foliage, as it does to the Scarlet Oak in its fruit : on this resemblance I have founded the latin specific name ambigua.

The leaves are large, smooth, and deeply sinuated at right angles to the main rib. The acorns are of the middle size, rounded at the end, and contained in scaly cups.

The wood is similar to that of the other species in- 


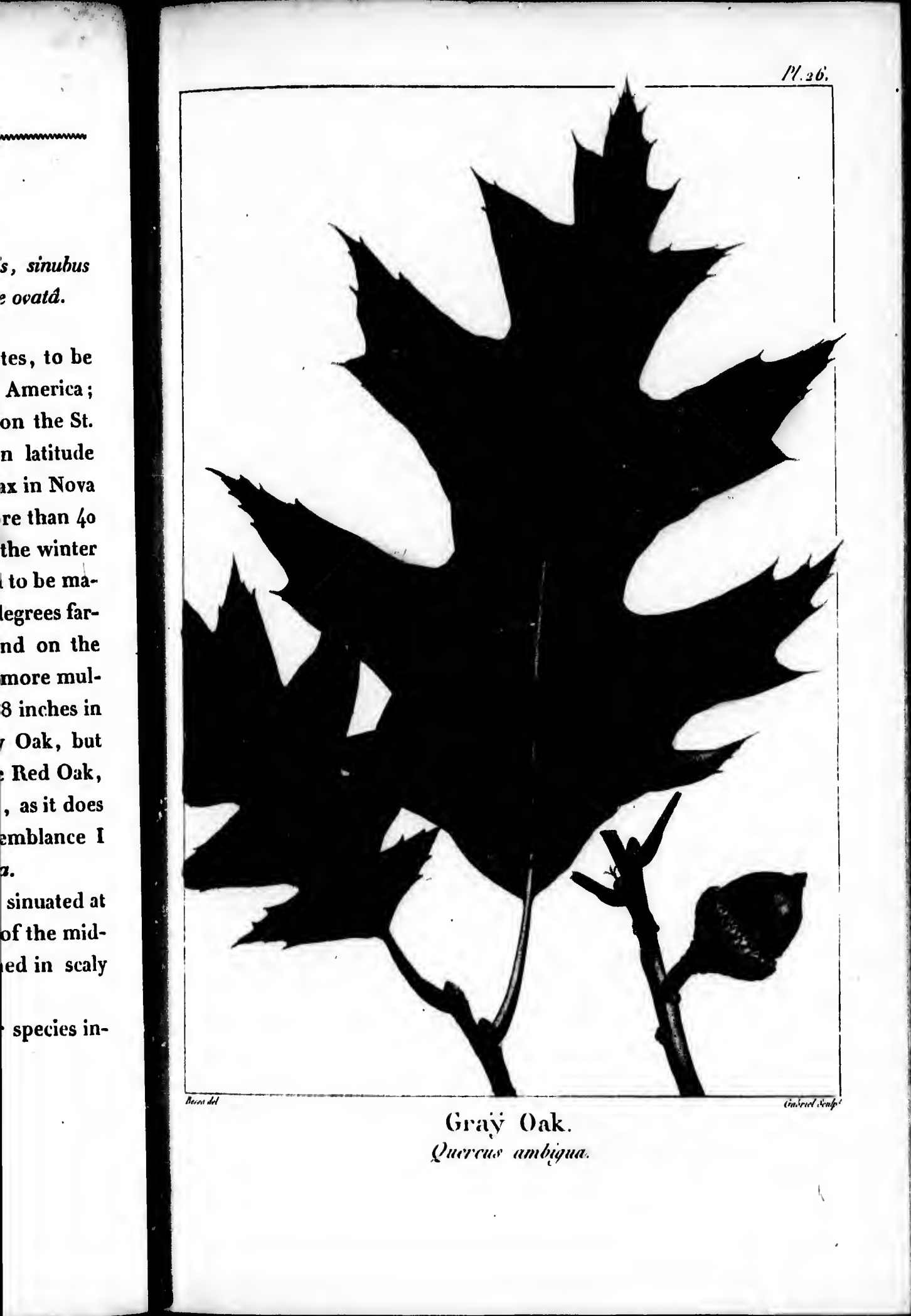


cluded under the common name of Red Oak. Its coarse and open texture renuers it unfit for any use except to contain dry wares ; but in districts where Oak wood is rare, recourse is had, for other purposes, to several species of inferior quality, which are still preferred to the Birch, the Beech, and the Pine. Thus the Grey Oak. is employed for the knees of vessels and for cartwrights' work; it is even preferred to the Red Oak, as being stronger and more durable.

This tree is without interest, as the regions in which it grows possess other species in every respect preferable, such as the White Oak; the Swamp White Oak, and the Rock Chesnut Oak.

\section{PLATE XXVI.}

$A$ branch with leaves and fruit of the natural size. 


\section{PIN OAK.}

Qurrcus palustris. Q. foliis profunde sinuatis, glabris, sinubus latis; fructu parvo; cupulâ scutellatâ, lovvi; glande subglobosa.

Tuss species, like the preceding, grows in Massachusetts, but is less common than in the vicinity of New York, in New Jersey, Pennsylvania and Maryland. I saw it abundant beyond the mountains near Pittsburgh in Ohio, and in East Tennesse, and my father found it multiplied in the country of the Illinois : I feel assured that it does not exist in Maine, Vermont and the Southern States. It is called Pin Oak in the lower part of New York and in New. Jersey, and Swamp Spanish Oak in Pennsylvania, Delaware and Maryland. The last of these denominations is sufficiently appropriate; but $I$ have preferred the second, because it is less liable to mistake, and is indicative of a characteristic arrangement of the branches.

The Pin Oak is a tall tree, which grows constantly in moist places, and of preference about the swamps enclosed in the forests. In these situations it is frequently more than 80 feet high and 3 or 4 feet in diameter. Its secondary branclies are more slender and numerous than is conmmon on so large a tree, and are intermingled so as to give it at a distance the appearance of being 


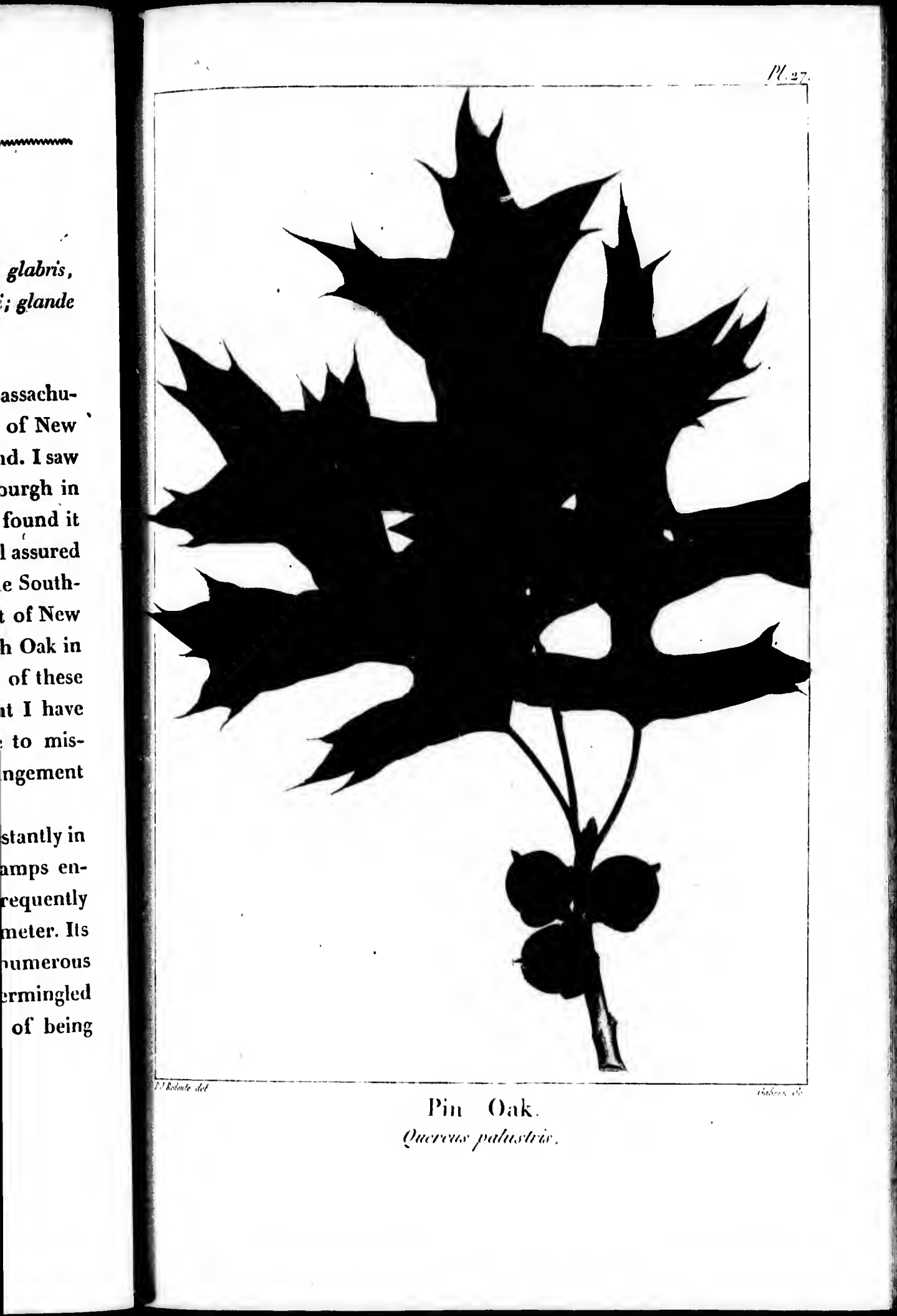




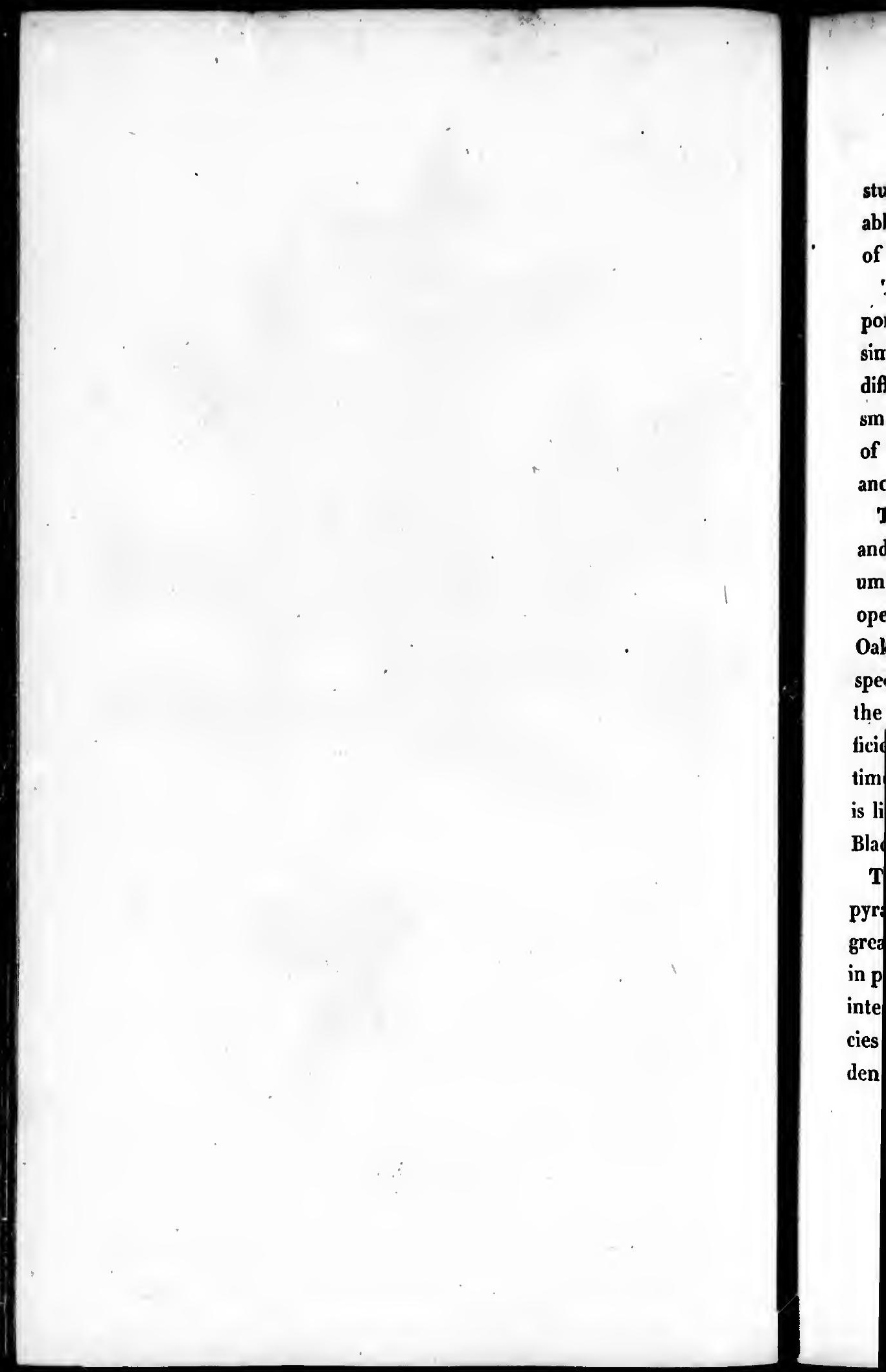


stuffed. This singular disposition renders it distinguishable at first sight in the winter, and is porhaps the cause of its being called Pin Oak.

The leaves are smooth, of a pleasing green, supported by long petioles, deeply laciniated and very similar to those of the Scarlet Oak, from which they differ principally in their proportions. The acorns are small, round, and contained in flat shallow cups, of which the scales are closely applied one upon another.

The bark upon the oldest trunk is scarcely cracked, and consists almost wholly of a very thick cellular integument. The wood is coarse-grained, with the pores open and larger than those of the Scarlet and Red Oaks : though stronger and more tenacious than those species, it is little esteemed for durability. It is used for the axle-trees of mill-wheels when White Oak of sufficient dimensions cannot be procured ; it is also sometimes, though rarely, made into staves, as the species is little multiplied compared with the Scarlet, Red and Black Oaks.

The Pin Oak, in its youth, assumes an agreeable pyramidal shape, and its light elegant foliage contributes greatly to its beauty. It deserves a conspicuous place in parks and gardens. It should never be deprived of its interior branches. The most beautiful stock of this species with which I am acquainted in Europe, is in a garden near Antwerp; it was about 20 feet high in 1804. 
and its brilliant and vigorous vegetation proved how well it was suited in the soil and climate.

PLATE XXVII.

A branch with leaves and fruit of the natural size. 



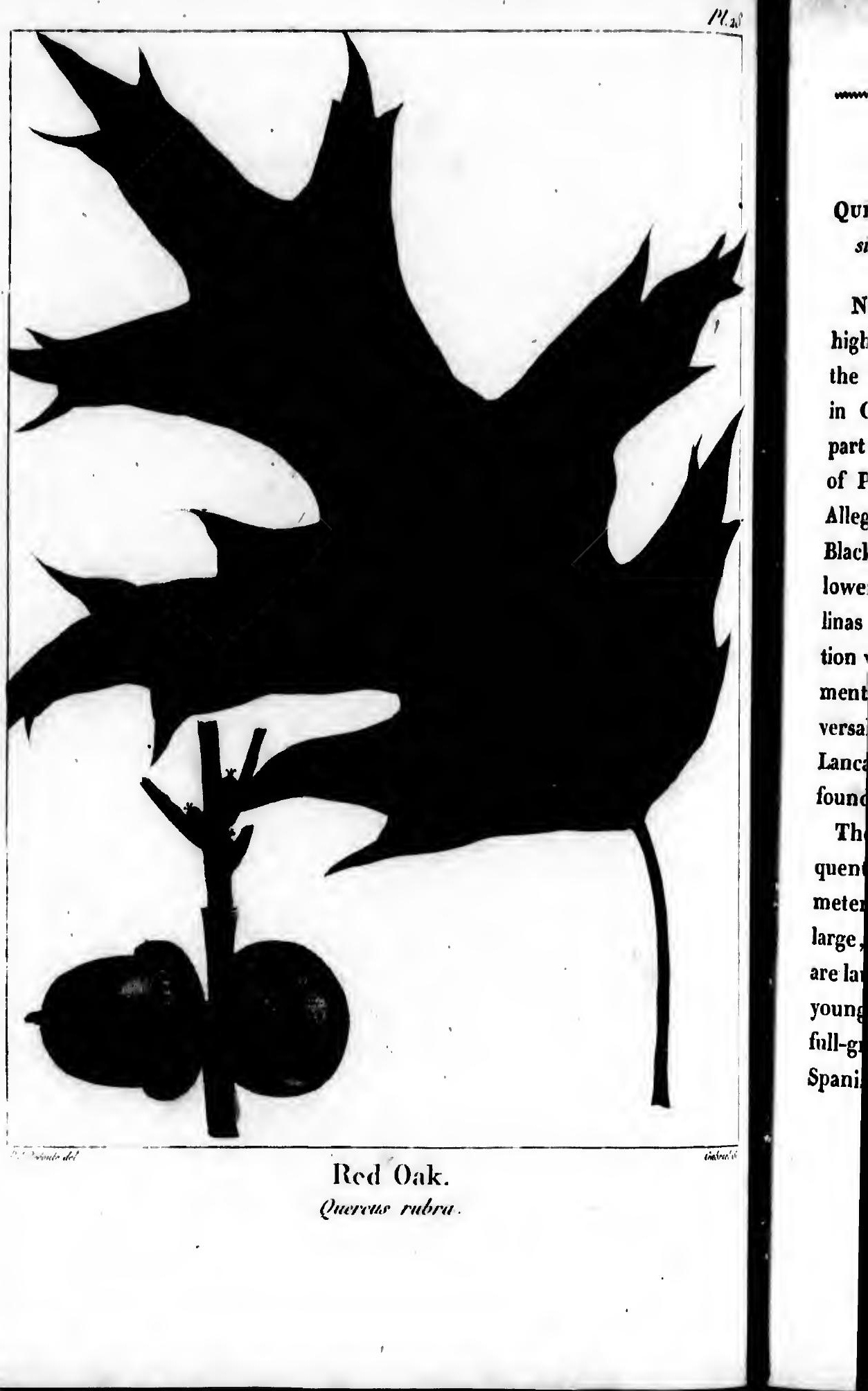




\section{3.}

\section{RED OAK.}

QUencus RUbra. Q. foliis longe petiolatis, glabris, obluse sinuatis; cupuld scutellatd, sublavi; glande subovatd.

Next to the Grey Oak this species is found in the highest latitude of all the American Oaks, and is one of the most common species in the Northern States and in Canada. Farther south, particularly in the lower part of New York, in New Jersey, the upper Districts of Pennsylvania, and along the whole range of the Alleghanies, it is nearly as abundant as the Scarlet and Black Oaks; but it is much less common in Maryland, lower Virginia, and the maritime parts of the Carolinas and Georgia. This remark confirms an observation which I have often made, that its perfect developement requires a cool climate and a fertile soil. It is universally known by the name of Red Oak, except near Lancaster in Pennsylvania, where it is somelimes confounded with the Spanish Oak.

The Red Oak is a tall, wide-spreading tree, frequently more than 80 feet high, and 3 or 4 feet in diameter. Its leaves are smooth and shining on both sides; large, deeply laciniated, and rounded at the base : they are larger and have deeper and narrower sections on the young stock than on the middle or the summit of the full-grown tree : these last resemble the leaves of the Spanish Oak, which, however, are always downy bc- 
neath, while those of the Red Oak are perfectly smooth. In the autumn they change to a dull red, and turn yellow before they fall.

The acorns are very large and abundant, rounded at the summit, compressed at the base, and contained in flat cups covered with narrow compact scales. They are voraciously devoured by wild animals, and by the cows, horses and swine which are allowed to range in the woods after the herbage has perished.

The wood is reddish and coarse - grained, and the pores are often large enough for the passage of a hair : it is strong but not durable, and is the last among the Oaks to be employed in building. Its principal use is for staves, which, at home, are used to contain salted provisions, flour, and other dry wares that are exported to the is. lands, aud, in the Colonies, to receive melasses and sugar.

The bark consists of a very thin epidermis and a very thick cellular integument. It is extensively used in tanning, but is less esteemed than that of the Spanish, Black and Rock Chesnut Oaks.

The Red Oak was one of the earliest American trees introduced into Europe. Large stocks are found on the estate of Duhamel, which yield seed abundantly, and even multiply naturally; but the quality of its wood is so inferior, that I cannot recommend its propagation in our forests.

$$
\text { PLATE XXVIII. }
$$

A branch with leaves and fruit of the natural size. 
smooth. turn yel-

junded at ntained in They are the cows, age in the

$d$, and the of a hair $:$ it ng the Oaks for staves, provisions, do the is. es and sugar. is and a very used in tanhe Spanish, nerican trees ound on the ndantly, and its wood is 50 opagation in

al size.

\section{ADDITIONS TO THE OAKS.}

In the botanical work of F. Pursh, Flora America Septentrionalis, published in England in 1814, the following species of Oak are added to those which $I$ have described.

Qunncus manitima. Q. folïs perennantibus, coriaceis, integerrimis, glabris, basi attcnuatis, apice mucronatis; cupuld scutellatd; glunde subrotunda.

A shrub from 3 to 8 feet high, found on the sea-coast in Virginia and Carolina : I consider it as a variety of the Willow Oak, Quercus phellos.

Quencus MYrTIroura. Q. foliis perennantibus, coriuceis, oblongis, integerrimis, glabris, utrinque acutis, supra nitidis, margine revolutis.

This species, of which Mr. Pursh appears to have seen neither the blossoms nor the acorns, escaped my researches; perhaps it is the variety of the Water Oak which I found among the Live Oaks and which preserves its leaves for three or four years.

QUencus hemisphenica. $Q$. foliis perennantibus, oblongo-lanceolatis, trilobis sinuatisque, lobis mucronatis, utrinque glabris. Willd.

Mr. Pursh has inserted this species from Willdenow, and he believes it to be a variety of the Water Oak, Quercus aquatica.

I. 
Quercus nana. $Q$. foluis cuneiformis, glabris, apice trilobis, basi subsinuatis, lobis, divaricatis, mucronatis, intermedio majore; cupuld scutellatd.

According to Mr. Pursh, this species is a low-growing shrub, distinct from the Water Oak, Quercus aquatica.

Quercus discoror. $Q$. foliis oblongis, pinnatifido-sinuatis, subtus pubescentibus, lobis oblongis, dentatis, setaceo-mucronatis; cupula turbinata.

This species of Mr. Pursh I consider as a variety of the Quencus tinctoria.

OAKS found in New Spain by Messrs. Humboldt and Bonpland, and described in their Nova Genera et Species Plantarum. PARIS, 18ı6.

QUnRCUS CONFERTIFoLIA. $Q$. ramulis abbreviatis; foliis brevissime petiolatis, confertis, lanceolatis, acuminatis, mucronato-aristatis, integerrimis, coriaceis; margine subreflexis, subtus pubescentibus; fructibus subgeminis, sessilibus.

This tree is 10 or 12 feet in height : it is evergreen, grows in the temperate and mountainous regions of New Spain, between Guanaxuato and Santa Rosa, and fructifies in September.

QUencus crassipes. $Q$. ramulis tuberculosis; foliis breviter petiolatis, lanceolato-oblongis, mucronatis, basi rotundatis, integerrimis, coriaceis, subtus cinereo-tomentosis; fructibus pedunculatis, subgeminis; pedunculis incrassatis; cupulis subturbinatis. 
apice tritis, inter-growing aquatica. ratifido-siatis, selaariety of boldt and ra et Speatis; foliis cuminatis, argine subinis, sessi-

vergreen, regions of Rosa, and foliis breis, basi rocomentosis; incrassatis;
This tree is about 20 feet high ; it is found on the low mountains of New Spain, near Santa Rosa, and fructifies in September and October.

Quencus mexicaxa. $Q$. ramulis foliisque, subtus stellatim mubescentibus, supra nitidis, lineari-oblongis, acutis, submucronatis, subcordatis, undulato-subsinuatis, subcoriaceis; fructibus solitariis, breviter pedunculatis; cupulis cyathiformibus.

This species rises from 15 to 20 feet ; it is very abundant between Acapulco and the city of Mexico, near Moxonera, Quaxiniquilapa and Chilpancingo, and is also found near Moran, Regla, Guanaxuato and Santa Rosa : it fructifies in September.

QUencus nanceonata. $Q$. ramulis tuberculatis; foliis oblongo-lanceolatis, utrinque acutis, undulato-repandis, coriaceis, supra nitidis, subtus stellatim pubescentibus; fructibus subternis, brevissime pedunculatis; cupulis cyathiformibus.

This tree equals, and sometimes exceeds, 20 feet in height : it abounds in the temperate regions of Mexico belween Moran and Santa Rosa, where it forms immense forcsts : it fructilies in September.

Quencus tridens. $Q$. ramis laevibus; foliis oblongis. basi rotundatis, apice cuspidato-tridentatis, membranaceis, supra pubescentibus, subtus tenuiter cinereo-tomentosis; fructibus ternis aut quinis, breviter pedunculatis.

This tree rises from to to 20 feet; it grows in the mountains near Moran in Mexico, and fructilies in May. 
QUercus laUnina. $Q$. ramulis glabris; foliis oblongis, acuminatis, basi subrotundatis; apicem versus subdentatis, coriaceis, glabris, nitidis; fructibus solitariis aut ternis, sessilibus; cupulis cyathiformibus.

This is a large tree, which resembles the Laurel, and attuins the height of 40 feet : it is found in the temperate parts of New Spain, in the environs of $\mathrm{Pa}$ chuca, Totonilco and Grande : it flowers in May.

QUercus RePaNDA. $Q$. fructicosa procumbens; ramulis foliisque subtus albido-tomentosis, subsessilibus, oblongis, obtusiusculis, basi incequalibus, sinuato-repandis, coriaceis; fructibus subsolitariis, sessilibus.

This is a shrub about 2 feet in height : it grows in moist shady situations, between Real del Monte and Moran, and flowers in May.

QUencus DePRESSA. Q. fructicosa, procumbens; ramulis pubescentibus; foliis sempervirentibus, oblongis, acutis, vuasi rotundaïs, argute et remote dentatis, rigidis, glabris, nitidis; fructibus geminis aut ternis, bresiter pedınculatis.

This species is an evergreen shrub, numerously ramified, and only 1 or 2 feet in height : it abounds in the same situations with the preceding, and flowers in May and June.

Quercus chrysophylda. Q. ramulis sulcutis, pubescentibus; foliis oblongis, basi rotundalis, apicem versus cuspidato-dentatis, membranaceis, supra nitidis, sublus tenuissime aureo-tomentosis; fructibus ternis aut quinis, pedun. culatis. 
oblongis, b́dentatis, ternis, ses-

e Laurel, nd in the ons of $\mathrm{Pa}$ Iay.

$s$; ramulis oblongis, , coriaceis;

$t$ grows in Monte and

ns; ramulis acutis, basi labris, nitisulatis. ously ramiands in the vers in May

is, pubescenversus cuspiublus tenuisinis, pedun-

This tree, which has a thin foliage, rises to the height of 30 or fo feet, and is from 18 to 24 inches in diameter: it grows in the temperate and stony parts of New Spain between Moran, Pachuca and Regla, and flowersin May. QUERCUS XALA PENSIS. $Q$. ramis tuberculatis; foliis longe petiolatis, ovato-oblongis, acuminatis, remote cuspidatodentatis, subcoriaceis, glabris; fructibus solitariis aut geminis, breviter pedunculatis; cupulis cyathiformibus.

This is a very lofty tree about 2 feet in diameter : it is very common in the forests near Xalapa, on the eastern side of the mountains ; it fructifies in January.

QUercus ACUTIFolin. $Q$. foliis ovato-lanceolatis, acuminatis, incequaliter subcordatis, subtus pulverulento-tomentosis, ferrugineis, sinuato - dentatis; dentibus elongatis, cuspidatis; fructibus geminis aut quaternis, brevissime pedunculatis.

A very lofty tree, about 2 feet in diameter, which grows on the west side of the mountains between Venta di Acaguisolta and la Majonera : it fructifies in May.

Quercus stipularis. $Q$. ramulis ferrugineo-tomentosis; foliis obovato-oblongis, subcordatis, argute et grosse dentatis; crasse coriaceis, supra nitidis, sublus flavido-tomentosis; stipulis persistentibus; fructibus solitanïs aut geminis. sessilibus.

This trec rises to the height of about 50 feet, and has a thick foliage : it is found on the mountains of Mexico near Actopan, and fructifies in May.

Quebcus syder OXYLA. Q. ramulis pubescentibus; foliis 
obovato-oblongis, basi indatis, apicem versus argute serratis, cordatis, remote et obtuse dentatis, membranaceis, subtus tomentosis; fructibus longe pedunculatis, subspicatis; cupulis hemispharicis.

A very lofty tree from 1 to 2 feet in diameter : it grows in the temperate regions of New Spain near Villalpando and Santa Rosa, and fructifies in September.

Quercus purcheln. $Q$. ramis tuberculatis; foliis obovato-oblongis, subcordatis, argute dentatis, coriaceis, supra nitidis, subtus tenuissime incano-tomentosis; fructibus geminis, breviter pedunculatis; cupulis depresso-sphaericis.

This tree is from 15 to 20 feet in height and grows in the mountainous regions of New Spain between Guxnaxuato and Santa Rosa ; it fructifies in September.

Quercus reticulata. $Q$. ramulis subpubescentibus; foliis subsessilibus, obovatis, cordatis, remote dentatis, coriacris, rugosis, subtus tenuissime tomentosis; fructibus gerninis, longe pedunculatis; cupulis cyathiformibus.

A tall tree which grows in the mountainous regions of New Spain between Santa Rosa and Guanaxuato, and fructilies in September.

Quercus crassifolia. Q. ramulis sulcatis, foliisque subtus flavescenti-tomentosis, breviter petiolatis, obovatis, cordatis, remote dentatis, crasse coriaceis; fructibus subternis, pedunculatis; cupulis subsphcericis.

This tree is from 30 to 40 feet high, and has a very thick foliage ; it is found in the stony and mountainous regions of New Spain near Chilpancingo, and fructifies in April. 
is argute ranaceis, bspicatis;

: it grows llalpando

foliis oboceis, supra uctibus geaericis. grows in veen Guanber.

ntibus ; foatis, coriatibus gemiregions of cuato, and oliisque sub. ovatis, cors subternis,

a very thick ous regions es in April.

Quzacus spicata. Q. ramulis tomentosis; foliis ellipticis, simuato-dentatis, coriaceis, supra nitidis, subtus tenuissime canescenti-tomentosis; fructibus subgeminis, brevissime pedunculatis; cupulis cyathiformibus.

This species is from 30 to 40 feet in height, and is found in shady situations near el Oyamel, el Jacal, and Cerro de las Nabajas : it fructifies in May.

QUencus PANDURATA. Q. ramulis lavibus, hirtis; folïs obovato-oblongis, subpanduratis, subcordatis, sinuato-dentatis, coriaceis, subtus pubescentibus; fructibus subquinis, pedunculatis ; cupulis cyathiformibus.

This species is about 15 feet high : it is found on the sides of the mountains in the kingdom of Mechoacan, between Ario and Patzcuaro : it fructifies in September.

Quencus ambigun. Q. ramulis glabris, obovato-ublongis, obtusis, basi rotundatis, subrepandis, membranaceis, subtu: tenuissime pubescentibus; fructibus quinis aut septenis, pedunculatis, pedunculis geminis, elongatis.

This tree is about 20 feet high, and is found in the temperate regions of Mexico near Moran, Cerro Ventoso and Omilton : it flowers in May.

Quercus graucescens. Q. ramulis angulatis; foliis brevissime petiolatis, obovato-oblongis, obtusiusculis, basi cuneatis, dentato-sinuatis, membranaceis, glabris, glaucescentibus; fructibus quinis aut septenis, pedunculatis.

A tall tree, very common in the warm parts of New Spain, between la Venta de la Majorena and Acaguisolla : it blooms in April. 
$112-136$

ADDITIONS.

Quencos obtusata. Q. namulis tuberculatis, tenuiter pubescertibus; foliis oblongis, obtusis, basi incequalibus, repandis, coriaceis, sublus pulverulento-pubescentibus; fructibus subquinis, pedunculatis ; cupulis campanuluto-glnbosis.

This species is very tall, with a remarkably straight trunk: it is found in the elevated and dry parts of New Spain near Ario, and flowers in September.

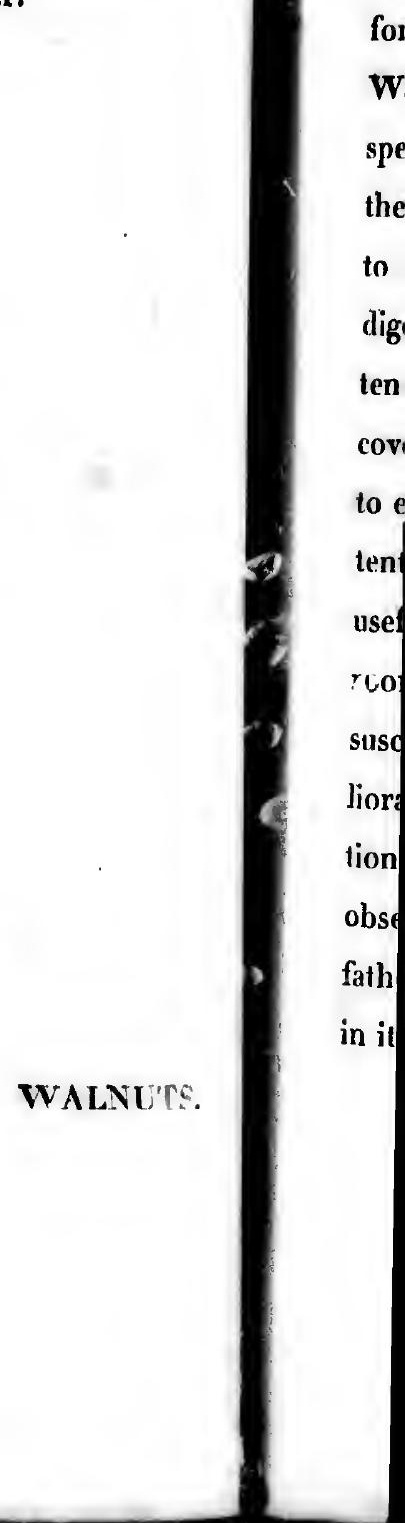


, tenuiter equalibus, tibus; fructo-globosis. ly straight ts of New

\section{WALNUTS.}

In the variety of trees which compose the vast forests of North America east of the Mississippi, the Walnut ranks after the oak, among the genera whose species are most multiplied. In this particular, the soil of the United States is more favoured than that of Europe, to no part of which is any species of this tree indigenous. I have distinguished in the United States ten species of Walnut, and others will probably be discovered in Louisiana : travellers who visit these regions to explore their natural history, should direct their attention to this class of vegetables, so interesting from the useful applications of their wood in the arts. There is rom to hope, also, that species may be discovered, susceptible, like the Pacanenut Hickory, of speedy melioration, by the aid of grafting and of attentive cultivation. Some weight is given this consideration, by an observation which I have heard often repeated by my father, that the fruit of the Common European Walnut, in its natural state, is harder than that of the merican I. 18 
species just mentioned, and inferior to it in size and quality. To the members of agricultural societies in the United States it belongs, to extend their observations and experiments on this subject, aiter the example of our ancestors, to whom we are indebted for a rich varicty of fruits, equally salutary and beautiful.

The Walnuts of North America appear to present characters so distinct as to require their division into two sections. These characters consist principally in the form of the barren aments or catkins, and in the greater or less rapidity of vegetation in the trees. The first section is composed of Walnuts with single aments, (Pl. 29 and 3o) and includes two species : the Black Walnut and the Butternut; to which is added the European Walnut. The second section consists of such as have compound aments, ( Pl. 36 ) and comprises eight species: the Pacanenut Hickory, Bitternut Hickory, Water Bitternut Hickory, Mockernut Hickory, Shellbark Hickory, Thick Shellbark Hickory, Pignut Hickory, and Nutmeg Hickory. The three first species of the second section bear some relation to those of the first, in their buds, which are not covered with scales. For this reason, I have placed them immediately next, beginning with the Pacanenut Hickory, which by its nu-

mero

Waln

cover

Tht

Hicko

This

of the

by thi tree 0 a strik thougl lets. 1 anothe pearan it belo differc ed; l'c the shic the am forests a sumi betwee Instilut Slates, 
W A LXบ

re and $s$ in the rvations mple of rich va-

present sion into ly in the he greatThe first aments, the Black d the Eu$s$ of such comprises t Hickory, ry, Shellt Hickory, ies of the the first, scales. For next, beby its nu-

merous leaflets, most nearly resembles the Black Walnut and the Butternut, whose buds are also uncovered.

Throughout the United States, the common name of Hickory is given to the species of the second section. This common appellation is due to certain properties of their wood, which, howerer modified, are possessed by them all, in a greater degree than lyy any other tree of Europe or America. These species exlibit also a striking analogy in their form, and in their leaves, though they differ in the number and size of their leaflets. To these sources of confusion, must be added another in the fruit, which is ofien so various in its appearance, that it is easy to mistake the species to which it belongs. It is not then, on the most remarkable differences alone, that our distinctions must be founded; recourse must also be had to an examination of the shoots of the preceding year, of the buds, and of the aments. It was only by constant observation in the forests of the country, pursued throngle the course of a summer, that $I$ became able readily to distinguish between mere varieties and species. M. Delitl: of the Institute of Egypt, who was at that time in the United States, took an actire pas' in niy peseatches, and re- 
sorted with me daily to the woods. Our investigations, I flatter myself, have had the result, which may always be hoped for, from unwearied perseverance.

From the considerations alleged, and principally from the striking resemblance of their woud, I have thought proper in describing the species of Hickory, to speak but summarily of their respective properties, and to treat of this part of the subject collectively and comparatively, more at large, in a separate article which will complete their history. 
stigations, nay always principally od, I have f Hickory, properties, ctively and rticle which

\title{
METHODICAL DISPOSITION
}

\section{OF THE WALNUTS}

\author{
OF NORTI AMERICA.
}

\begin{abstract}
Munacia Polyandria, LiNN. Terebenthaceu, Juss.
\end{abstract}

$$
\text { I. SECTION. }
$$

Simple aments. (Pl. 29 and 30.)

VEGETATION RAPID.

I. Common European Walnut. Juglans regia.

2. Black Walnut. . . . . Juglans nigra.

3. Butternut. ...... Juglans cathartica.

\section{2." SECTION.}

Compound aments, each peduncle bearing three.

( Pl. 36 , fig. 3.)

$$
\text { VEGETATION SLOW. }
$$

4. Pacanenut Hickory - . . Juglans olicaeformis.

5. Bitternut Hickory. . . Juglans amara.

6. Water Bitternut Hickory. . Juglans aquatica.

7. Mockernut Hickory. . . Juglans tomentosa. 


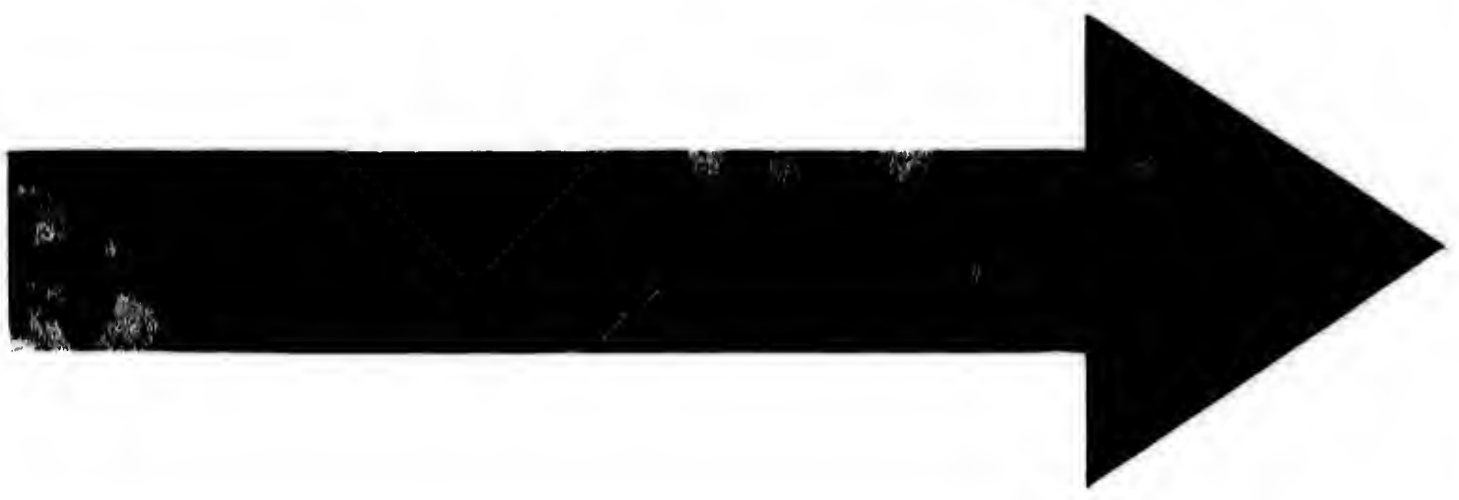




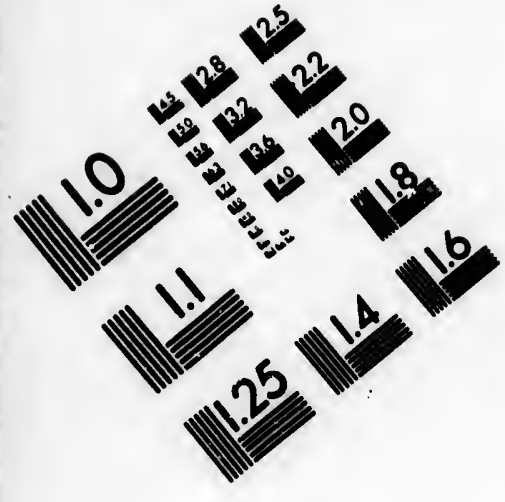

IMAGE EVALUATION

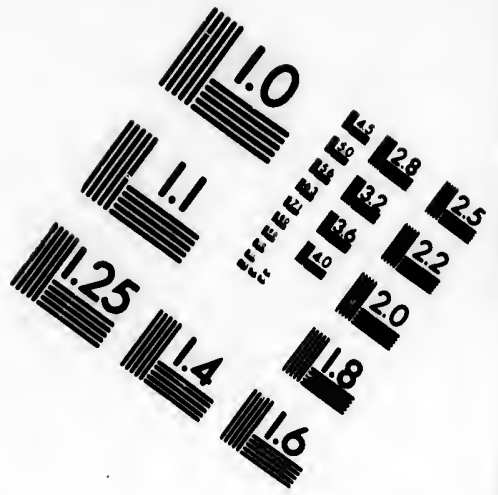
TEST TARGET (MT-3)
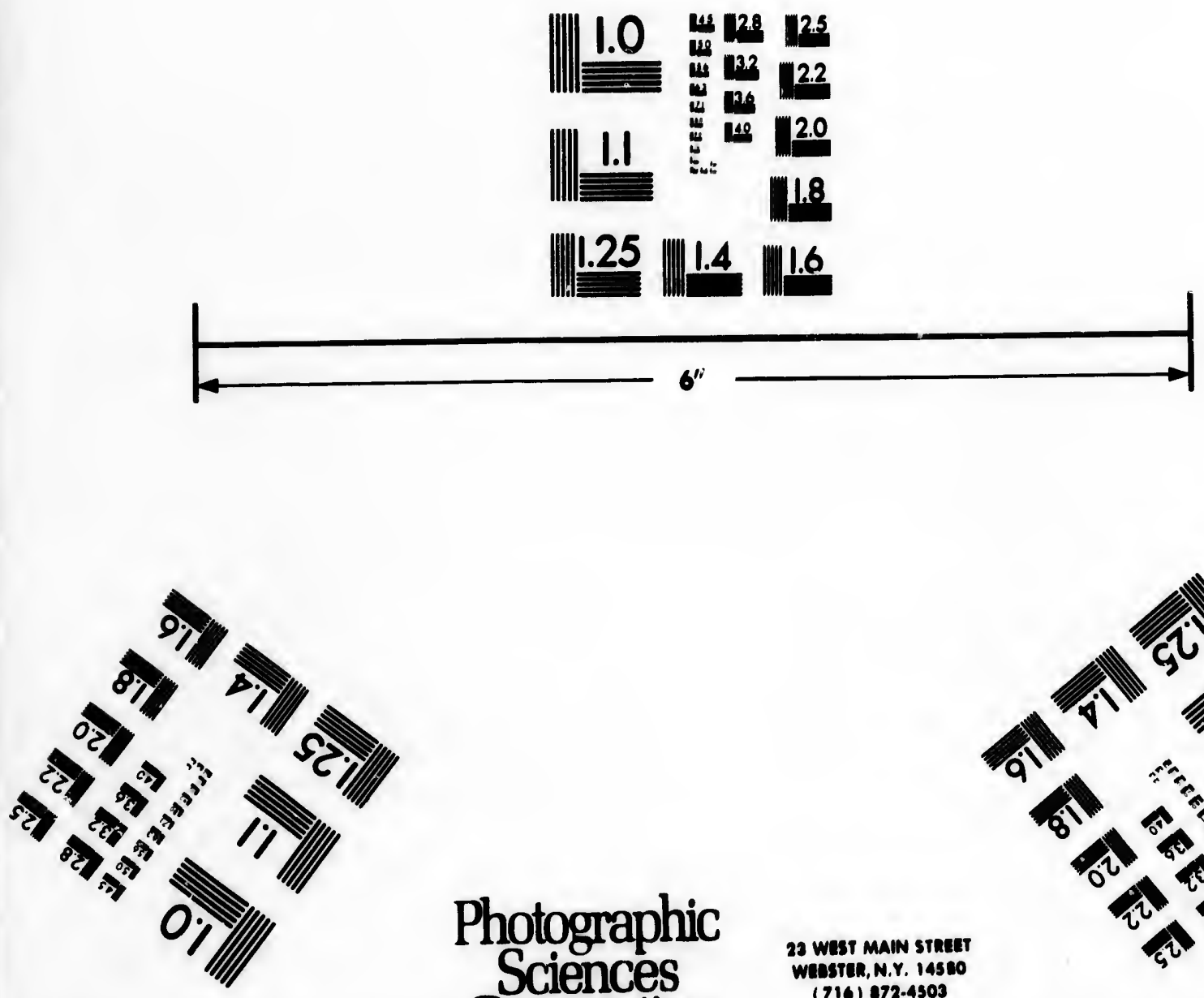

Photographic Sciences

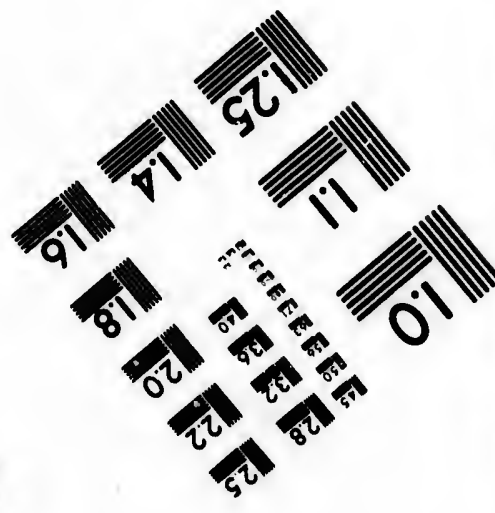
Corporation 
142. METHODICAI Disposition, etc.

8. Shellbark Hickory. . . . Juglans squamosa.

9. Thick shellbark Hickory. - . Juglans laciniosa.

10. Pignut Hickory. . . . Juglans porcina.

1x. Nutmeg Hickory. . . . Juglans myristica formis. 



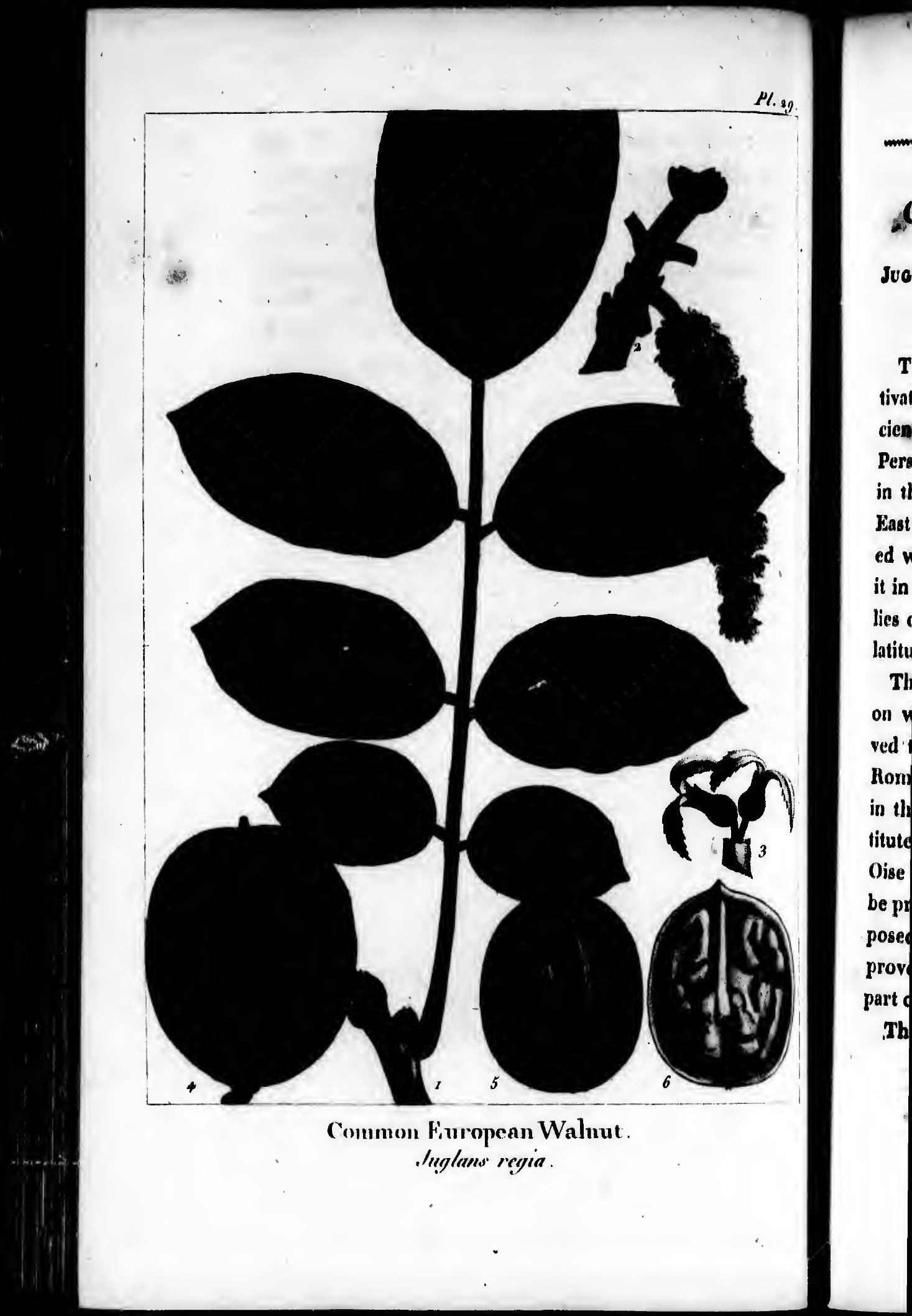




\section{COMMON EUROPEAN WALNUT.}

Jugraxs nzo1A. J. foliolis subseptenis, ovalibus, glabris, subserratis, subarqualibus: fructibus subovalibus.

The Walnut which for several centuries has been cultivated in Europe is a native of Asia. According to an ancient but uncertain tradition, its fiuit was brought from Persia with the Peach and the Apricot. My father, who in the years 1782,83 , and 84 , visited this part of the East to examine its natural productions, first ascertained with exactness, the origin of this tree : he found it in the natural State, in the Province of Ghilan, which lies on the Caspian Sea, between the $35^{\circ}$ and the $40^{\circ}$ of latitude.

The period of its introduction into Europe, a point on which ancient authors leave us in obscurity, is proved to be remote, by several rites in use among the Rornans : such, for instance, as the distribution of nuts in the Cerealia. In the village testival of the Rosiere, instituted by St. Médard, at Salency, Department of the Oise, 1200 years ago, it is directed, that an offering be presented to the young maid who is crowned, composed of nuts and other fruits of the Country : which proves the tree to have been already naturalised in that part of France.

The Walnut is common throughout the center of Eu- 
rope, but it flourishes most in the western and southern Deparments of France, in Spain and in Italy, which approach nearest to the latitude in which it grows in the natural state. In France, it is only in the West and South, that the regetation of theWalnut is perfectly secure from frost, that its wood is of a superior quality, and that its fruit is regularly yielded in sufticient abundance to become an article of commerce.

The European Walnut is one of the tallest and ost beautiful among fruit trees, and one of the most remarkable for the amplitude of its summit, and the thickness of its shade. On the trunk of old trees, which frequently are several feet in diameter, the bark is thick and deeply furrowed; on the upper branches, it is grey and smooth, a good deal resembling that of the Butternut. The leaves are borne by long petioles, and are composed of 2,3 , and sometimes $h$ pair of leaflets, surmounted by an odd one. The hets are oval and smooth; when bruised, they exhale a strong aromatic odour. In the extreme heat of summer, the emanations from the Walnut are so powerful as to produce unpleasant effects upon some persons, if they slumber in its shade.

The flowers of the Common European Walnut, like those of the Black Walnut and Butternut, appear before the unfolding of the leaves; the barren ones in single, pendulous, imbricated aments; the fertile ones on separate branches, at the end of the young shoots, 
1 southern

aly, which

1 it grows

a the West

nut is per-

a superior

ed in suffi-

nmerce.

st and thost

ce most re-

it, and the

rees, which

the bark is

ar branches, ling that of petioles, and pair of leafilets are oval a strong aroummer, the tul as to proons; if they

Walnut, like , appear bcrren ones in e fertile ones young shoots,

and commonly in pairs. The fruit is green and oval, and in the natural state contains a small hard nut. In the most esteemed cultivated species, the fruit is oval and strongly odoriferous, about an inch and two thirds long, and from an inch and a quarter to an inchand a half in diameter. The nut occupies two thirds of its volume.

Towards autumn, the husk softens, and decaying from about the nut, allows it to fall. The shell is slightly chanpeled; : and so thin as to be easily crushed by the fingers. The kernel is of a very agreeable taste $:$ it is large, covered with a fine pellicle, and separated by a thin partition which may readily be detached both from the shell and from the kernel. The nuts are better tasted and easier of digestion, soon after their maturity, than later in the season, when the oily principle becomes perfectly formed; they are then oppressive if immoderately eaten.

A dessert of an excellent relish is made by extracting the kemels a fortnight before they are ripe, and seasoning them with the juice of green grapes and salt. They should be thrown into water as soon as they are taken from the shell, and allowed to remain till the moment when they are seasoned to be set upon the table. They are sold in Paris by the name of $\mathrm{Cer}$ neaux, and a greater quantity of walnuts is consumed in this way by people in easy circumstances, than after they are perfectly ripe : the use of them is then almost exclusively confined to the lower classes.

נ. 
The Common Walnut is more multiplied in the Departments of France which lie between the $45^{\circ}$ and the $48^{\circ}$ of latitude; than in any other part of Burope. In these Departments, it is planted in the midat of cultivated tields, like the apple tree for cider, in those of the north and of the center : the fruit, the oil, and the wood, mas be considered as forming one of their principal branches of commerce.

In extracting the oil of Walnuts; certain delicate centions are necessary to insure.its fineness. When the fruit is gathered, and the nuts are separated from the husks, they hould be kept dry, and occasionally moved till they are used. The properest time for the operation is at the close of winter, as in this interval, the change by which the mucilage of the fruit is converted into oil has become completely effected, and by loniger delay the kernel grows rancid, and the oil is of a vitiated quality. The nut is cr ed by striking it on the end with a small malle, and pains are taken not to bruise the kernel: The slight ligneous partition is detached, and such kernels as are partially spoiled, are : selected und thrown aside. The sound kernels, thus cleared trom extry particle of the shell, should be sent immediately to the mill; as they. soon become rancid by exposure to the air! They are crushed by a vertical stone, which turns in a circular trough, and is moved by a horse or by a current of water. The paste is next enclosed in bags of strong

linet und is of for whic custc the for $t$ rin the oil $\mathbf{b}$ the s tely 1 and charg ranci 1atior expre serve. ration the $\mathrm{c}$ and whicl vases In 
lied in the he $45^{\circ}$ and of Europe. te midst of $x$, in those the oil, and one of their

elicate hen the fruit m the husks; moved till operation is , the change is converted ed , and by and the oil ed by striand pains e slight ligrnels as are $n$ aside. The article of the mill, as they. ir. They are in a circular by a current gs of strong

linen and oubmitted to the press. The oil which flows under this first pressure without the application of heat? is of the best quality. It is : very clear, and is proper for food; but it sensibly retains the taste of the nut? which in general is not agreeable to persons unaccustomed to it, so that the consumption is limited to the Departments where it is made. To be kept sweet for the table, it should be drawn off several times durin the first months, carefully corked, and kept in the cellar, as it is more easily affected than any other oil by the action of air and heat.

After the first expression, the paste is emptied from the sacks, moistened with warm water, and moderately heated in coppers. It is then replaced in the sacks and returned to the press. The oil of the second discharge, is highly coloured, and very speedily becomes rancid; it is therefore employed only in the prepaation of colinrs. The cakes which remain after the expression is finished, are proper for fattening fowls.

Although nut oil, as an article of diet, is in general use in the Departme where the tree abounds.; it serves a still more important purpose in the preparation of fine colours. It is preferred on account of the complete and rapid manner in which it dries; and of the facility of obtaining it perfectly limpid; which is done by diffusing it upon water in large shallow rases.

In copper-plate printing, walnut oil is copsidered, in 
Paris, indiopensably necessary fora fine impression, in black or in colours. But there are peculiar modes of preparing It for the several colours with which it is to be mixed. Thus for white, blue, light green, and the intermediate shades, it is reduced by boiling to two thirds of its bulk, but for dark green and black, to one fifth, which leaves it a thick, semifluid substance. To facilitate the process, one tenth part of linseed oil is added 10 it; it is then placed in an iron or copper vol, over an active, clear fire. When it begins to boil rapilly, the vessel is uncovered, and the oil takes fire by contact with the flame, and burns till it is reduced to the proper consistency : sometimes it is not allowed to kindle, but when the ebullition commences, crusts of bread are thrown into it, which remain till the necessary evaporation is effected, and are then taken out, charged with mucilagenous particles. The principal advantage of this oil, in the preparation of white lead for painting the interior of houses, as well as of the colours employed in copper-plate printing, is the longer and more perfect prese back of prints done with it do not turn yellow like othere.

A tine stomachic liquor is made with the fruit of the Walnut gathered a month before its maturity. Twelve green nuts in the husk are bruised and thrown into a pint of good brandy; after they have steeped three wecks, the brandy is filtered through brown paper,

and cord

Di to $\mathrm{d}$ bron also in ir reser appe of its woor and from impo was In th nitur piece thick mus〉 is us nisch ties whic 
pression, in modes of hich it is to and the ino two thirds o one fifth, e. To facioil is added oper vitsel, to boil ratakes fire by reduced to t allowed to 8 , crusts of II the necestaken out, e principal n of white is well as of nting, is the le tints. The yellow like fruit of the rity. Twelve thrown into teeped three rown paper, and a quarter of a pound of loat sugar is added. This cordial improves by age.

Diers obtain by boiling the husks, when they begin to decay, and the bark of the roots, a substantial dark brown, with which they die woolens. Cabinet-makers also make use of it, in staining other species of wood in imitation of Walnut.

Among the American Walnuts which are found east of the Mississippi, the Black Walnut bears the greatest resemblance to the European Walnut, in its general appearance, in its flowers and fruit, and in the qualities of its wood : in foliage they are strikingly different. The wood of the European Walnut is inferior in strength and weight, and I believe, far more liable to injury from worms.

Twenty or thirty years ago, before Mahogany was imported in such abundance into Europe, Walnut wood was employed almost exclusively, in Cabinet-making. In the country, it is still in general use, and the furniture made of it is far from being inelegant, especially, pieces obtained from such old trees as bear small and thick shelled nuts. It is preferred for the stocks of muskets; and in Paris and Brussels, no other wood is used for the pannels of carriages. The old trees furnisch excellent screws for large presses. Great quantities of wooden shoes are manufactured of Walnut, which are more highly esteemed than others.

The wood of the Europcan Walnut is largely exported 
from the south of France to the North, and to Holland and Germany : formerly, it was carried to England.

Like other fruit trees, whose perfection is among the " noblest conquests of industrious man ", the Walnut has been greatly improved, by long and careful cultivation. There are 7 or 8 cultivated varieties; whose superiority is principally apparent in the augmented size of the fruit, and in the diminished thickness of the shell. Of these the most esteemed, after that which I have described, are the St. Jean and the Jauge Walnuts. The St. John Walnut, is a variety obtained within a few years. It yields fruit as large and as abundant as the common Walnut, and for that part of Europe which lies beyond the $4^{\circ}$ of latitude, it possesses an advantage, in opening its vegetation three weeks later, and in being thus secure from the injuries of frost. The Jauge Walnut is chiefly remarkable for the size of its fruit, which is twice as large as the variety represented in the plate. It is unproductive, and the kernel does not fill the shell. The Jauge nut is made into cases by jewellers, and furnished with trinkets for the amusement of children.

The wood of the Black Walnut is already superior to that of the European Walnut, and it will acquire a still finer grain, when it is raised on lands that have been long under cultivation. It is solely for the excellency of its truit, and the decided superiority of its oil in the preparation of colours, that the European 
o Holland

England.

is among

in ", the

8 and ca-

varieties;

e augmen-

thickness

after that I the Jauge

y obtained

id as abun-

lat part of de, it posation three n the injuremarkable large as the luctive, and puge nut is ith trinkets

dy superior 11 acquire a that have r the excelority of its European

Walnut should be warmly recommended to the attention of Americans. It would thrive better than elsewhere in places where the Black Walnut naturally abounds. In some parts of Pensylvania and Maryland, the BlackWalnuts have been preserved in clearing the lands : great advantage would be tound in grafting them with the European Walnut. The limbs should be cut 15 inches from the trunk, and from the stumps will spring vigorous shoots, which the second year may the grafted by inoculation. Fifty or sixty buds shonld be set upon each tree, as is practised near Lyons; where it is found, that by inserting the Walnut of St. John on the common Walnut, the fruit is rendered finer, and the crop more certain. Black Walnuts thus grafted begin to bear the 5.th year. On estates where no Black Walnuts exist, the deficiency may be supplied by planting the nuts, and grafting the young stocks when they come to the height of 8 or 10 feet.

It should be observed, that in the Walnut, more than any other tree, it is necessary on account of the loose texture of the wood and the large volume of the pith, to protect the amputated limbs from the weather. A covering of clay should be so nicely adapted to the exposed surface, as entirely to exclude the rain, otherwise decay will commence, and spread itself into the body of the tree.

In those parts of France, Belgium and Germany, where the Walnut is not cultivated for commerce, the 
trees have generally sprung from the seed, which is the cause of the inferiority of their fruit. For it is observed that, with a few accidental exceptions, the finest fruits and fiowers degenerate in reproduction. This inconvenience would be experienced in the United States, and as there do not perhaps exist in that Country, south of the Hudson river, ten European Walnut trees, I should recommend the obtaining from Bordeaux of young graft. ed trees, which will soon furnish the means to such proprietors as wish to enrich their estates with this useful and magniticent tree.

\section{PLATE XXIX.}

Fig. 1, $A$ leaf of half the natural size. Fig. 2, Bapren fowers. Fig. 3, Fertile flowers. Fig. 4, $A$ nut in its husk of the natural size. Fig. 5, A nut without its husk. Fig. 6, A nut deprived of half the shell to show the keniel. 



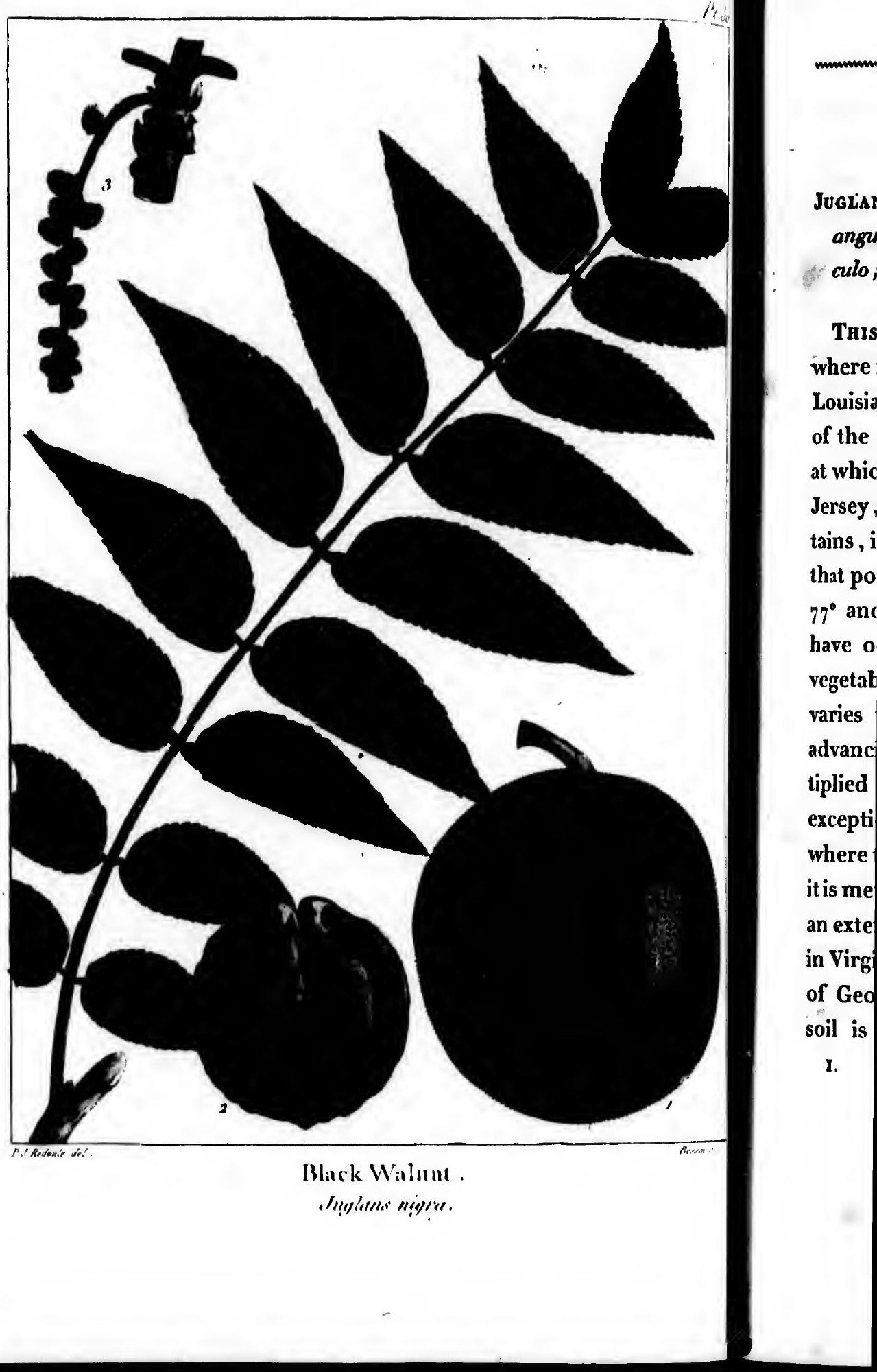




\section{3.}

\section{BLACK WALNUT.}

Juglans Nigna. J. foliolis quindenis, subcordatis, supernè angustatis, serratis: fructu globoso, punctato, scabriusculo; nuce corrugatá.

THus tree is known in all parts of the United States where it grows, and to the french of Upper and Lower Louisiana, by no other name than Black Walnut. East of the Alleghany Mountains, the most Northern point at which it appears, is about Goshen in the Sate of NewJersey, in the latitude of $400^{\circ} 50^{\prime}$. West of the Mountains, it exists abundantly two degrees farther north, in that portion of Genesee, which is comprised between the $77^{\circ}$ and $79^{\circ}$ of longitude. This observation, as I shall have occasion to remark, is applicable to several other vegetables, the northern limit of whose appearance varies with the climate, and this becomes milder in advancing towards the West. The Black Walnut is multiplied in the forests about Philadelphia, and with the exception of the lower parts of the Southern States, where the soil is too sandy, or too wet as in the Swamps, it is met with to the banks of the Mississippi, throughout an extent of 2000 miles. East of the Alleghany mountains in Virginia, and in the upper parts of the Carolinas and of Georgia, it is chiefly confined to vallies where the soil is deep and fertile, and which are watered by

I.

20 
Creeks and Rivers : in the Western Country, in Genesee and in the States of Ohio and Kentucky, where the soil in general is very rich, it grows in the forests, with the Coffee-tree, Honey Locust, Red Mulberry, Locust, Shellbark Hickory, Black Sugar Maple; Hack Berry, and Red Elm; all of them trees that prove the goodness of the soil in which they are found.

It is in these Countries that the Black Walnut dis. plays its full proportions. On the banks of the Ohio and on ,the Islands of this beautiful river, I have often seen trees of 3 or 4 feet in diameters and 60 or 70 feet in height. It is not rare to find them of the thickness of 6 or 7 feet. Its powerful vegetation clearly points out this, as one of the largest trees of America. When it stands insulated, its branches, extending themselves horizontally to a great distance, spread into a spacious head, which gives it a very majestic appearance.

The leaves of the Black Walnut when bruised emit a strong aromatic odour. They are about 18 inches in length, pinnate, and composed in general of 6,7 , or 8 pair of leaflets surmounted by an odd one. The leaflets are opposite and fixed on short petioles; they are acuminate, serrate, and somewhat downy. The barren flowers are disposed in pendulous and cylindricalaments, of which the peduncles are simple, unlike those of the Hickories. (Pl. 3o. fig. r.) The fruit is round, odoriferous, of rather an uneven surface, and always ap- 
Genesee the soil is, with Locust, Berry, he good:-

lnut dis. he Ohio I have nd 60 or n of the in clearly of Ame-

$s$, exten-

e, spread majestic

ised emit inches in 6,7 , or The leafthey are he barren alaments, those of nd, odolways ap-

pears at the extremity of the branches : on young, and vigurous trees, it is sometimes 7 or 8 inches in circumference. The husk is thick, and is not as in the Hickories divided into sections; but when ripe it softens and gradually decayo. The nut is hard, somewhat compressed at the sides, and sulcated. The kernel, which is divided by firm ligneous partitions, is of a sweet and agreeable taste, thoug inferior to that of the European Walnut. 'These nuts are sold in the markets of New-York, Philadelphia, and Baltimore, and served upon the tables. The girs of the fruit varies considerably, and depends upoitur vigour of the tree, and upon the nature of the soil and of the climate. On the banks of the Ohio, and in Kentucky, the fruit with tke husk is 7 or 8 inhes in compass with the nut proportionally large : in Gencsee on the contrary, where the cold is intense, and in fields exhausted by cultivation, where these trees have been preserved since the first clearing of the land, it is not of more than half this bigness. Some variations are observed in the form of the fruit, and in the moulding of the shell; but these I consider as merely, accidental differences. Indeed there is no genus of trees in America, in which the fruit of a given species exhibits such various forms, as in the Walnut ; and doubtless this circumstance has mislead observers, who, being acquainted only with the small number of trees existing in European gardens, have described them as distinct species. 
The bark of the Black Walnut is thick, blackish, and on old trees deeply furrowed. When the timber is freshly cut, the sap is white and the heart of a violet colour, which after a short exposure to the air assumes an intenser shade, and becomes nearly black : hence probubly is derived the name of Black Walnut. There are several qualities for which its wood is principally esteemed ; it remains sound during a long time, even when exposed to the influences of heat and moisture; but this observation is applicable only to the heart, the sap opeedily decays : it is very strong and retenacious : when thoroughly seasoned it is not liabse to warp and oplit; and its grain is sulficiently fine and compact to admit of a beautiful polish. It possesses in addition to these advantages, that of being secure from worms. On account of these excellencies, it is preferred and successfully employed in many kinds of work. East of the Alleghanies, its timber is not extensively used in building houses, but in some parts of Kentucky and Ohio, it is split into shingles 18 inches long and from 4 to 6 inches wide, which serve to cover them : sometimes also this timber enters into the composition of the frame. But it is chiefly in cabinet making ; that the Black Walnut is employed wherever it abounds. By selecting pieces from the upper part of the trunk, immediately below the first ramification, furniture is sometimes made, which from the accidental curlings of the grain is highly beautiful; but as its colour soon changes to a dusky hue, the

Wild The I milita Red $f$ and el posts as it la it app assure farthe phia,

The cerlain wroug is assey than $t$ Carolin to be advant serves the $\mathrm{m}$ often $s$ vessels the $\mathrm{OH}$ On the greatly them fa than 40 
kish, and imber is I a violet assumes $k$ : hence ut. There rincipally me, even moisture; zeart, the enacious : warp and ompact to ddition to m worms. erred and rk. East of ly used in and Ohio, om 4 to 6 sometimes the frame. ck Walnut pieces from below the de, which ghly beauy hue, the
Wild Cherry wood is frequently preferred for this use. The Black Walnut is also employed for the stocks of military muskets; it is stronger and tougher than the Red flowering Maple, which, from its superior lightness and elegance, is chosen for towling pieces. In Virginia posts are very commonly made of Black Walnut, and as it lasts undecayed in the ground from 20 to 25 years, it appears every way fit for this purpose. I have been assured that it makes excellent naves for wheels, which farther proves its strength and durability. At Philadelphia, coffins, are universally made of it.

The timber of this tree is also excellently adapted to certain uses in Naval Architecture. It should never be wrought till it is perfectly seasoned, after which it is asserted to be more durable, though more brittle; than the White Oak. Breckel in his history of North Carolina, affirms that it is not liable, like the Oak; to be attacked by sea-worms in warm latitudes. This advantage if it is real, is highly important, and deserves to be ascertained by farther observation. In the marine lumber yards of Philadelphia, I have often seen it used for knees and floor timber; but in the vessels built at Wheeling and Marietta, small towns on the Ohio, it constitutes a principal part of the frame. On the river Wabash, canoes are made of it which are greatly esteemed for strength and durability. Some of them fashioned from the trunk of a single tree, are more than 40 feet long, and 2 or 3 feet wide. 
The Black Walnut is exported in small quantities to England in planks of . 2 inches in thickness. These planks are sold at Philadelphia, at four cents a foot.

The husk of the fruit yields a colour similar to that which is obtained from the European Walnut. It is used in the country for dying woolen stuffis.

This tree has been long since introduced, in England and France, into the gardens of the lovers of foreign culture. It succeeds perfectly and yields fruit abundantly. Though differing widely from the European species, it bears a nearer resemblance to it than any other American Walnut. By comparing the two species as to their utility in the arts and in commerce, it will appear, that the wood of the Black Walnut is more compact, heavier and much stronger; that it is susceptible of a finer polish, and that it is not injured by worms ; qualities which, as has been seen, render it fit not only for the same uses with ours, but also for the larger works of archifecture.' These considerations sufficiently evince that it is a valuable tree, and that it is with great reason, that many proprietors in America have spared it, in clearing their new lands. On high roads, I am of opinion that it might be chosen to succeed the Elm; for experience has proved, that to insure success in the continued cultivation of trees or herbaceous plants on the same soil, the practice must be varied with species of different genera.

Nuts of the European Walnut and of the Black Walnut 
antities to ese planks

ar to that It is used

in England of foreign abundantly. species, it her Amerias to their ppear, that act, heavier a finer po; qualities only for the ger works of ently evince reat reason, pared it, in ds , I am of ed the Elm; uccess in the us plants on with species Black Walnut have been planted at the same time in the same soil; those of the Black Walnut are observed to shoot more vigorously, and to grow in a given time to a greater height. By grafting the European upon the American species, at the height of 8 or 10 feet, their advantages , with respect to the quality both of wood and of fruit . might be united.

\section{PLATE XXX.}

A leaf of half its natural size. Fig. $\mathrm{I}$, A nut with its hik. Fig. 2, A mut without its husk. Fig. 3, A barren ament. 


\section{BUTTERNUT.}

Juglamb catenatica. J. foliolis subquindenis, lanceolatis; bast rotundato-obtusis, subtis tomentosis, leviter serratis: fructu oblongo, ovato, apice rimoso, viscido, longè pedunculato, nuce oblongd, acuminatd, insigniter insculpteacrabrosa.

Tuts species of Walnut is known in North Americu, under different denominations. In Massachusetts, New Hampshire, and Vermont, it bears the name of Oil nut: in Pennsylvania and Maryland, and on the hanks of the Ohio, it is generally known by that of White Walnut ; in Connecticut, New York, New Jersey, Virginia, and in the mountainous districts of the upper parts of the Carolinas, it is called Butternut. The last of thesc names I have retained, because it is not wholly nnknown in those parts of the United States where the others are in general use, and because the wood is employed in the neighbourhood of New York, for a greater variety of uses than elsewhere. I think also that the latin specific name Cuthartica, which was long since given it by Doctor Cutler of Massachusetts, would be definitively substituted for that of Cinerea, by which it has hitherto been distinguished among Botanists. 'This last appellation, derived from the colour of the secondary branches, whose bark is smooth and greyish, suggests only an unimportant characteristic, 


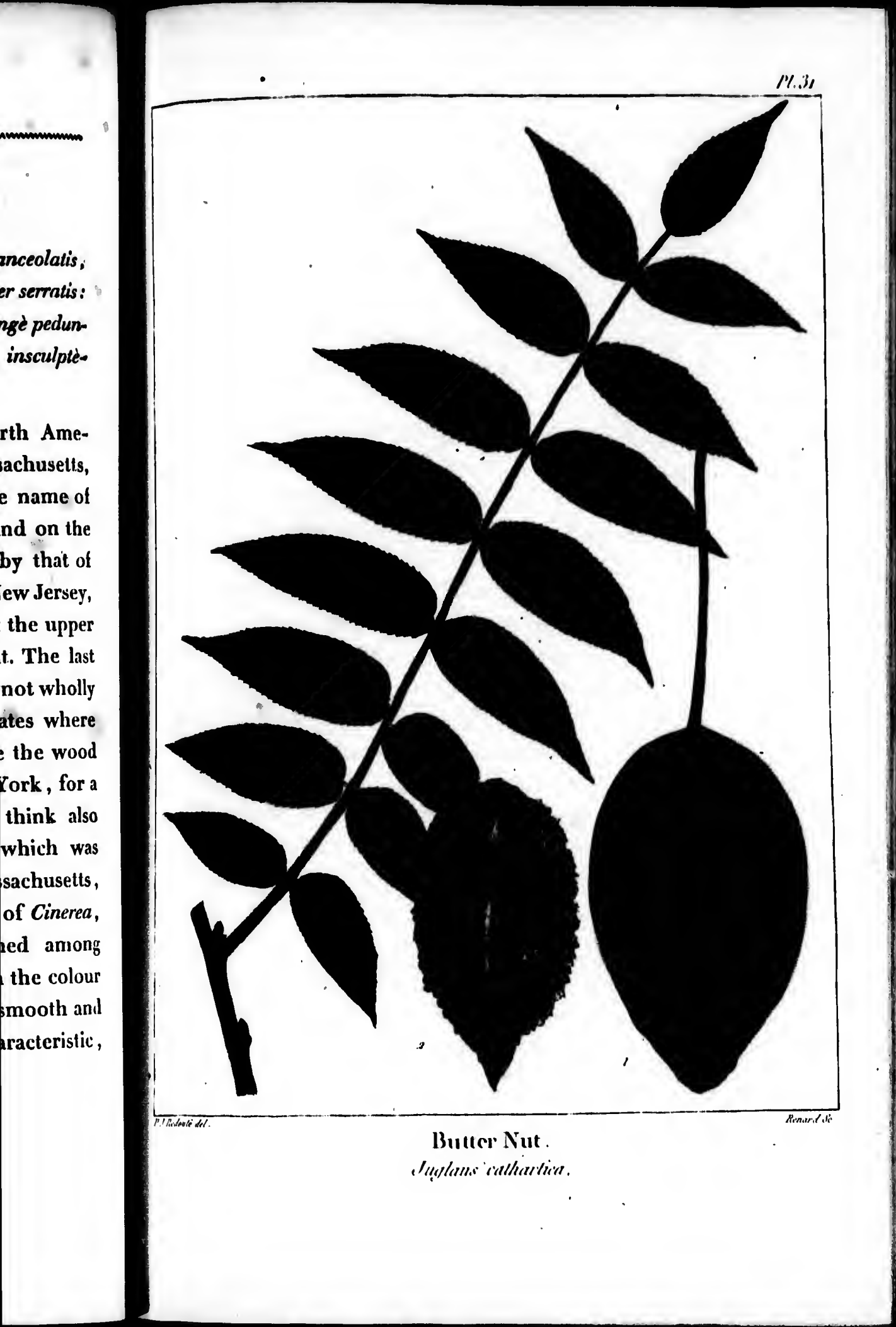


while Th in th in the of the parts where of the regior the St that s] this tr nowh which rietta hardly uimos as som of the The w produr interst root. I from $t$ and wi even $\mathrm{x}$ directi

I. 
while the first expreices one of the most interesting properties of the tree.

The Butlernut is found in Upper and Lower Canada, in the District of Maine, on the shores of Lake Erie, in the States of Kentucky and Tennessee and on the banks of the Missouri; but I have never met with it in the lower parts of the Carolinas, of Georgia, and of East Florida, where the nature of the sroil and the intemperate heat of the summer, are unfavorable to its vegetation. In cold regions, on the contrary, its growth is luxuriant ; for in the State of Vermont, where the winter is so rigorous that sledges are used during four months in the year, this tree attains a circumference of 8 or 10 feet. I have nowhere seen it more abundant, than in the bottoms which border the Ohio between Wheeling and Marietta : but the thickness of these forests, which are hardly penetrated by the sun, appears to prevent its utmost expansion. I have seen here no trees as large as some in New Jersey, on the steep and elevated banks of the Hudson, nearly opposite to the city of New York. The woods in this place are thin, and the soil cold, unproductive, and interspersed with large rocks, in the interstices of which the biggest Butternuts have their root. I have measured some of them, which at 5 feet from the ground, were 10 or 12 feet in circumference, and which were 50 feet in height, with roots extending even with the surface of the ground, in a serpentine direction, and with little variation in size, to the dis-

I. 
tance of 40 feet. The trunk ramifies at a small height, and the branches seeking a direction more horizontal than those of other trees, and spreading widely, form a large and tufted head, which gives the tree a remarkable appearance.

The buds of the Butternut., like those of the Black Walnut, are uncovered. In the spring its vegetation is forward, and its leaves unfold a fortnight earlier than those of the Hickories. Each leaf is composed of 7 or 8 pair of sessile leaflets, and terminated by a petiolated odd one. The leaflets are from 2 to 3 inches in length, lanceolate, serrate, and slightly downy. The barren flowers stand on large cylindrical aments, which are single, 4 or 5 inches long, and attached to the shoots of the preceding year; the fertile flowers on the contrary, come out on the shoots of the same spring, and are situated at their extremity. The ovarium is crowned by two rose coloured stigmata. The fruit is commonly single, and suspended by a thin, pliable peduncle, about 3 inches in length; its form is oblong-oval without any appearance of seam.It is often 2 inches and $a$ half in length, and 5 inches in circumference, and is covered with a viscid adhesive substance, composed of small transparent vesicles, which are easily discerned with the aid of a glass: The nuts are hard, oblong, rounded at the base, and terminated at the summit, in an acute point; the surface is very rough, and deeply and irregularly firrowed. They are ripe, in the neighbourhood of New 
reight, and ontal than orm a large cemarkable

f the Black getation is arlier than ed of 7 or 8 petiolated s in length, The barren which are the shoots on the conspring, and is crowned commonly uncle, about without any alf in length, ered with a hall transpaho the aid of nded at the acute point; 1 irregularly cood of New

York, about the 15th $^{\text {th }}$ of september, a fortnight earlier than the other species of Walnut. Some years they are so abundant, that one person may gather several bushels of them in a day. The kernel is thick and oily, and soon becomes rancid; hence, doubtless, are derived the names of Butternut and Oilnut. These nuts are rarely seen in the markets of New York and Philadelphia. The Indians who inhabited these regions, pounded and boiled them, and separating the oily substance which swam upon the surface, mixed it with their food: When the fruit has attained about half its growth, it is sometimes used for making pickles, being first plunged into boiling water; and thoroughly wiped, to clean it of its down, and afterwards preserved in vinegar.

The Black. Walnut and Butternut, when young, resemble each other in their foliage, and in the rapidity of their growth; but when arrived at maturity, their forms are so different, as to be distinguishable at first sight. Remarkable peculiarities are also found, on examining their wood, especially when seasoned; the Black Walnut is heavy, strong, and of a dark brown colour; while the Butternut is light, of little strength, and of a reddish hue : but they possess in common, the great advantage of lasting long, and of being secure from the annoyance of worms. From its want of solidity and from the difficulty of procuring pieces of considerable length, Butternut timber is never used in the cities; in the construction of honses, though it is sumetimes employed 
for this purpose in the country. In some Districts of New Jersey, it is often taken for the sleepers which are placed immediately on the ground, in the framing of houses and barns. As it long resists the effects of heat and moisture, it is esteemed for the posts and rails of rural fence, and for troughs for the use of cattle. For corn shovels and wooden dishes, it is preferred to the Red flowering Maple, because it is lighter and less liable to split ; consequently articles made of it, are sold at a higher price. Near New-York, I have observed it to be made use of for canoes formed of one or two logs, and for the futtocks destined to give them solidity; but in boats of considerable size some stronger wood is selected for this purpose. At Pittsburgh on the Ohio, the Butternut is sometimes sawn into planks, for the construction of small skiffs, which, on account of their lightness, are in request for descending the river. At Windsor in Vermont, it is used for the pannels of coaches and chaises; the workmen find it excellently adaptted to this object, not only from its lightness, but because it is not liable to split, and receives paint in a superior manner : indeed $I$ have remarked that its pores are more open than those of the Poplar and Basswood.

The medicinal properties of Butternut bark, have long since been proved, by several eminent Physicians of the United States, and among others, by Doctor Cutler. An extract in water, or even a decoction sweet-

ened catha oper: delic: has $\mathrm{s}$ cases of pil a scr in th provi of th it by reduc whick exteri cellula contir the li have a vulsiv ache : these somet colou for th

On pos"d beauti 
stricts of which are aming of ts of heat d rails of attle. For ferred to - and less , are sold bserved it ce or two n solidity; ger wood the Ohio, , for the t of their river. At $s$ of coachatly adaptiness, but es paint in ed that its poplar and ark, have Physicians py Doctor tion sweet-

ened with honey, is acknowledged to be one of the best cathartics afforded by the materia medica; its purgative operation is always sure, and unattended in the most delicate constitutions, with pain or irritation. Experience has shewn that it produces the best effects in many. cases of dysentery. It is commonly given in the form of pills, and to adults, in doses from half a scruple to a scruple. It is not however in general use, except in the country, where many of the farmers wives provide a small store of it in the spring, for the wants of their families and of their neighbours. They obtain it by boiling the bark entire in water, till the liquid is reduced by evaporation, to a thick, viscid substance, which is almost black. This is a faulty process; the exterior bark, or the dead part which covers the cellular integument, should first be taken off, for by continued boiling, it becomes charged with four fifths of the liquid, already enriched with extractive matter. I have also seen this bark successfully employed as a revulsive, in inflammatory ophthalmias and in the toothache : a piece of it soaked in warm water, is applied in these cases to the back of the neck. In the country it is sometimes employed, for dying wool of a dark brown colour; but the bark of the Black Walnut is preferable for this purpose.

On a live tree, the cellular integument, when first expos'd, is of a pure white, in a moment it changes to a beautiful lemon colour, and soon after to a deep brown. 
If the trunk of the Butternut is pierced in the month which preceds the unfolding of the leaves, a pretty copious discharge ensues of a slightly sugary sap, from which, by evaporation, sugar is obtained of an quality inferior to that of the Sugar Maple.

Although the Butternut, as has been seen, possesses useful properties, I do not think it sufficiently valuable, either in the arts , or for fuel, to recommend its introduction into the forests of the old continent : it should find place only in our pleasure grounds.

\section{PLATE XXXI.}

$A$ leaf of half its natural size. Fig. I, A nut with its husk. Fig. 2, A nut without ils husk. 
month

retty co-

p, from

a quality

possesses

valuable, its intro-

it should

hits husk. 


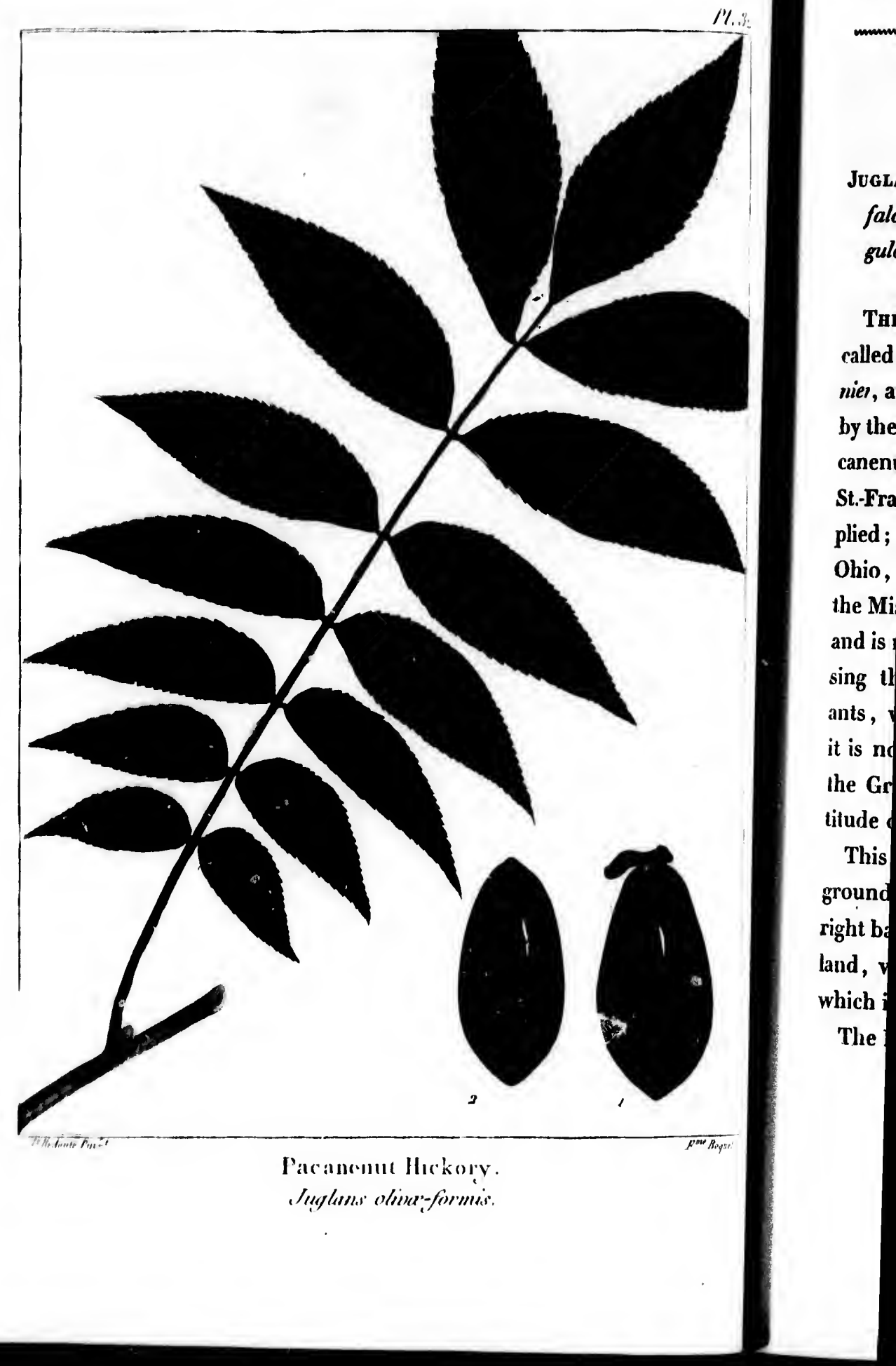




\section{7.}

\section{PACANENUT HICKORY.}

Juglans onveronmis. J. foliolis plurimis, subpetiolatis, falcatis, serratis; fructu oblongo, prominulo-quadrangulo; nuce olivoeformi, levi.

Tris species, which is found in upper Louisiana, is called by the French of Illinois and New Orleans, Pacamier, and its fruit Pacanes. This name has been adopted by the inhabitants of the United States, who call it Pacanenut. On the borders of the rivers Missouri, Illinois, St.Francis, and Arkansas, it is most abundantly multiplied; it is also common on the river Wabash; on the Ohio, it is found for 200 miles from its junction with the Mississippi : higher than this, it becomes more rare, and is not seen beyond Louisville. My father, in traversing this country, learned from the French inhabitants, who ascend the Mississippi in quest of furs, that it is not found on that river, beyond the mouth of the Great Mackakity, which discharges itself in the latitude of $42^{\circ} 51^{\prime}$.

This tree grows most naturally, in cold and wet grounds. There is a swamp of 800 acres, situated on the right bank of the Ohio, oppositite to the river Cumberland, which is said to be entirely covered with it , and which is called by the French, la pacanière.

The Pacanenut is a beautiful tree, with a straight and 
well shaped trunk in the forests it reaches the height of 60 or 70 feet. Its wood is coarse grained, and like the other Hickories, heavy and compact : it possesses also great strength and durability ; but in these respects, it is inferior to some species which remain to be described. Its buds, like those of the Black Walnut, and Butternut are uncovered. The leaves are from 12 to 18 inches in length, and are supported by petioles some what angular, and slightly downy in the spring. Each leaf is composed of 6 or 7 pair of sessile leaflets, and terminated by a petiolated odd one, which is commonly smaller than the pair immediately preceding. The leaflets, on flourishing trees, are from 2 to 3 inches long, ovate, serrate, and remarkable for the circular form of the upper edge, while the lower one is less rounded. It is also to be noticed, that the main rib is placed a littlebelow the middle of the leaflet.

The nuts, which are usually abundant, are contained in a husk from I to 2 lines thick, and have four slightly prominent angles, corresponding to their internal divisions. They vary in length from an inch to an inch and a half, are pointed at the extremities, of a cylindrical form, and of a yellowish colour marked, at the periodof perfect maturity, with blackish or purple lines. The shell is smooth and thin, though too hard to be broken by the fingers : the kernel is full, and not being divided by ligneous partitions, is easily extracted. These nuts, which are of a very agreeable taste, form an object of 
pacanenut hickory.

169

height of d like the sesses also espects, it described. I Butternut inches in what anguaf is comterminated only smalce leaflets, ing, ovate, rm of the anded. It is d a little be-

e contained have four heirinternal ninch and a drical form, riodof perThe shell is bken by the divided by These nuts, n object of petty commerce, between Upper and Lower Louisiana. From New Orleans, they are exported to the West Indies, and to the ports of the United States. They are not only better than any other species of North American walnuts, but they appear to me to be more delicately flavoured than those of Europe. And besides, varieties of the Pacanenut are found, whose fruit is far superior to that of the European Walnut unimproved by culture. I am opinion then, that this tree merits the attention both of Americans and Europeans, and that by assiduous cultivation, it may be brought to a high degree of perfection. These advantages, it is true, are balanced in part by the slowness of its growth; there are trees in France which have been planted more than thirty years, and which do not yield fruit.

If the practise should be successfully adopted, of grafting the Pacanenut on the Black Walnut, or on the Common Walnut, its vegetation would be incomparably more rapid, and no motive, would discourage its propagation in Europe.

\section{PLATE XXXII.}

A leaf of half its natural size. Fig. 2, A nut with its husk. Fig. 2, A nut without its husk. 


\section{BITTERNUT HICKORY.}

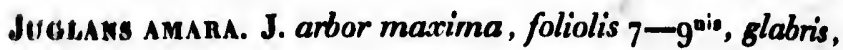
comspinue serratis, impari breviter petiolato : fructu subrolundo-ovoudeo, superne' suturis prominulis; nuce levi, subglobosd, mucronatd : putamine frugili, nucleo amaro.

Turs species is generally known in New Jersey by the name of Bitternut Hickory; in Pennsylvania, and particularly in the county of Lancaster, it is called White Hickory and sometimes Swamp Hickory; farther south, it is confounded with the Pignut, Hickory; the French of Illinois, like the inhabitants of New Jersey, give it the name of Bitternut, which, as it indicates one of the peculiar properties of the fruit, I have chosen to retain.

The Bitternut Hickory, I believe, is nowhere found much beyond the boundaries of Yermont, in the latitude of $4^{\circ}$. It is not seen in the Province of Maine, where the borders of the rivers offer situations, analogous to those in which it abounds, a few degrees farther south. In Bergen woods, six miles from NewYork, and in the bottoms which stretch along the Ohio, it grows to a very lofty stature; 1 have measured trees which were 10 or 12 feet in circumference, and 70 or 80 feet high. It attains these dimensions, only in spots where the soil is excellent, constantly cool, and often inundated by creeks and rivers. It is probably because it thrives most in such situations, 
that

Hick

bave

after

fruif much ries a tion Each and than ches acum dark still b In kory the b flexib the $b$ fertil at the $\mathrm{Th}$ is so there surm the $\mathrm{f}$ those 
that it is sometimes called Swamp Hickory. Ot all the Hickories the vegetation of this specied is the latest ; I have uniformly observed, that its leaves unfold a fortnight after the others: On flourishing trees at an age to bear fruig, they are 12 or 15 inches in length and nearly as much in breadth; the size, as in other vegetables, varies according to the nature of the soil, and the situation of the leaf upon a lower or upon an upper branch. Lach leaf is composed of 3 or 4 pair of leaflets, and terminated by an odd one, which is larger than the preceding pair. The leaflets are about 6 inches in length, and an inch in breadth, sessile, ovalacuminate, deeply toothed, smooth, and of a pretty dark green. When the tree has shed its leaves, it may still be distinguished by its yellow and naked buds.

In Pennsylvania and New Jersey, the Bitternut Hicknry blossoms about the $25^{\text {th }}$ of May. The peduncles of the barren flowers are in pairs, each supporting three flexible and pendulous aments : they are attached at the basis of the shoots of the same season, while the fertile aments, which are not conspicuous, are placed at the extremity.

The fruit is ripe about the beginning of October; it is so plentiful that several bushels are sometimes gathered from a single tree. The husk is thin, fleshy, and surmounted, on its upper half by four appendages in the form of wings. It never becomes ligneous, like those of the other Hickories, but softens and decays. The 
form of the nut in this species is more constant and more regular than in the others. It is broader than it is long, being 6 or 7 lines one way and 10 lines the other. The shell is white, smooth, and thin enough to be broken by the fingers. The kernel is remarkable for the deep inequalities ' produced on every side by its foldings. It is so harsh and bitter, that squirrels and other wild animals will not feed on it, while any other nut is to be found.

In some parts of Pennsylvania where this tree is muitiplied, an oil is extracted from the nuts, which is used for the lamp and for other inferior purposes. But from these experiments, in which individuals have succeeded, it is not to be concluded that a sufficient product of this sort can be obtained to form a branch of industry ; neither this, nor any other species of Walnut, is abundant enough in the United States.

In the texture of its bark, and in the colour of its heart and sap, the Bitternut Hickory resembles the other Hickories, and its wood possesses, though in an inferior degree, the weight, strength, tenacity, and elasticity, which so plainly distinguish them. At Iancaster, it is used for fuel, but it is not considered superior to the White Oak, nor sold at a higher price.

The Bitternut Hickory exists and bears fruit in several gardens in France; but as it is of no value for its nuts, and flourishes only in very tertile soils; as its 



\section{WATER BITTERNUT HICKORY.}

JUgLans AQUATICA. J. foliolis 9-1 $\mathrm{I}^{\text {nia }}$, Innceolato-acuminatis, subserratis, sessillibus, impari breviter petiolato: fructibus pedunculatis, nuce subdepressa, parva, nubiginosá, tenená.

No specilic name has hitherto been given to this species, which is confined to the Southern States ; it is confounded with the Pignut Hickory, though differing from it in many respects. The name which I propose, appears sufficiently appropriate, for I have always found this tree in swamps, and in the ditches which surround the rice fields, where it is accompanied by the Red flowering Maple, Tupelo, Cypress, and Carolina Po. plar. The Water Bitternut Hickory grows to the height of 40 or 50 feet, and in its general appearance, resembles the other Hickories. Its leaves are 8 or 9 inches long, and of a beautiful green. They are composed of 4 or 5 pair of sessile leaflets surmounted by a petiolated odd one. The leaflets are serrate, 4 or 5 inches long, 8 or 9 lines broad, and very similar to the leaves of the Peach tree.

The husk is thin, and the nuts are small, angular, a little depressed at the sides, somewhat rough, of a reddish colour, and very tender. 'The kernel is formed in folds like that of the Bitternut Hickory: as may be supposed, it is not eatable. The wood of this species, 

thou
Hick
the ,
TI
ced
of or
place
clear
of th
useft
other
A
with, 
though partaking of the common properties of the Hickories, is in every respect inferior to the others, from the nature of the grounds on which it grows.

The Water Bitternut Hickory, which I have introduced into France, flourishes unchecked by the rigours of our Winters ; but I do not think it deserves to find a place, in the forests of Europe, alor to be spared in clearing the new lands of America. The southern parts of the United States possess many sorts of timber more useful in building, to which purpose this, like the other Hickories, is poorly adapted.

\section{PLATE XXXIV.}

A branch with leaves of the natural size. Fig. 1, INuts with their husks. Fig. 2, Nuts without their husks. 


\section{MOCKERNUT HICKORY.}

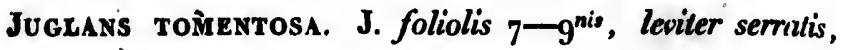
conspicuè villosis, impari subpetiolato : amentis compositis, longissimis, filiformibus, eximiè tomentosis: fructu globoso vel oblongo; nuce quadranguld, crassi, durissimaque.

IN the parts of New Jersey which lie on the river Hudson, and in the City of New York and its vicininity, this species is known by the name of Mockernut Hickory, and less commonly of White heart Hickory; at Philadelphia and Baltimore, and in Virginia, that of Common Hicknry is the only one in use. The French of Illinois call it Noyer dur , or Hard Walnut. The first of these denominations, which is descriptive of the fruit, I have for that reason adopted.

This species is not, as the name which it bears it that country would indicate, more multiplied in Pennsylvania, and farther south, than the other Hickories. I have not seen it north of Portsmouth in New Ilampshire, though roo miles south in the neighbourhood of Boston and Providence, it is common. It is most abundant in the forests that still remain on the coast of the middle States, and in those which cover the Upper parts of the Carolinas and of Georgia ; but in the last mentioned states, it becomes more rare in ap- 


\section{PI.3.;.}

er serrutis, entis com:omentosis: da, crassá,

the river its viciniof Mockerheart Hicn Virginia, a use. The alnut. The ptive of the sears it that n Pennsylickories. I ew Ilamphbourhood It is most on the coast cover the ; but in the are in ap-

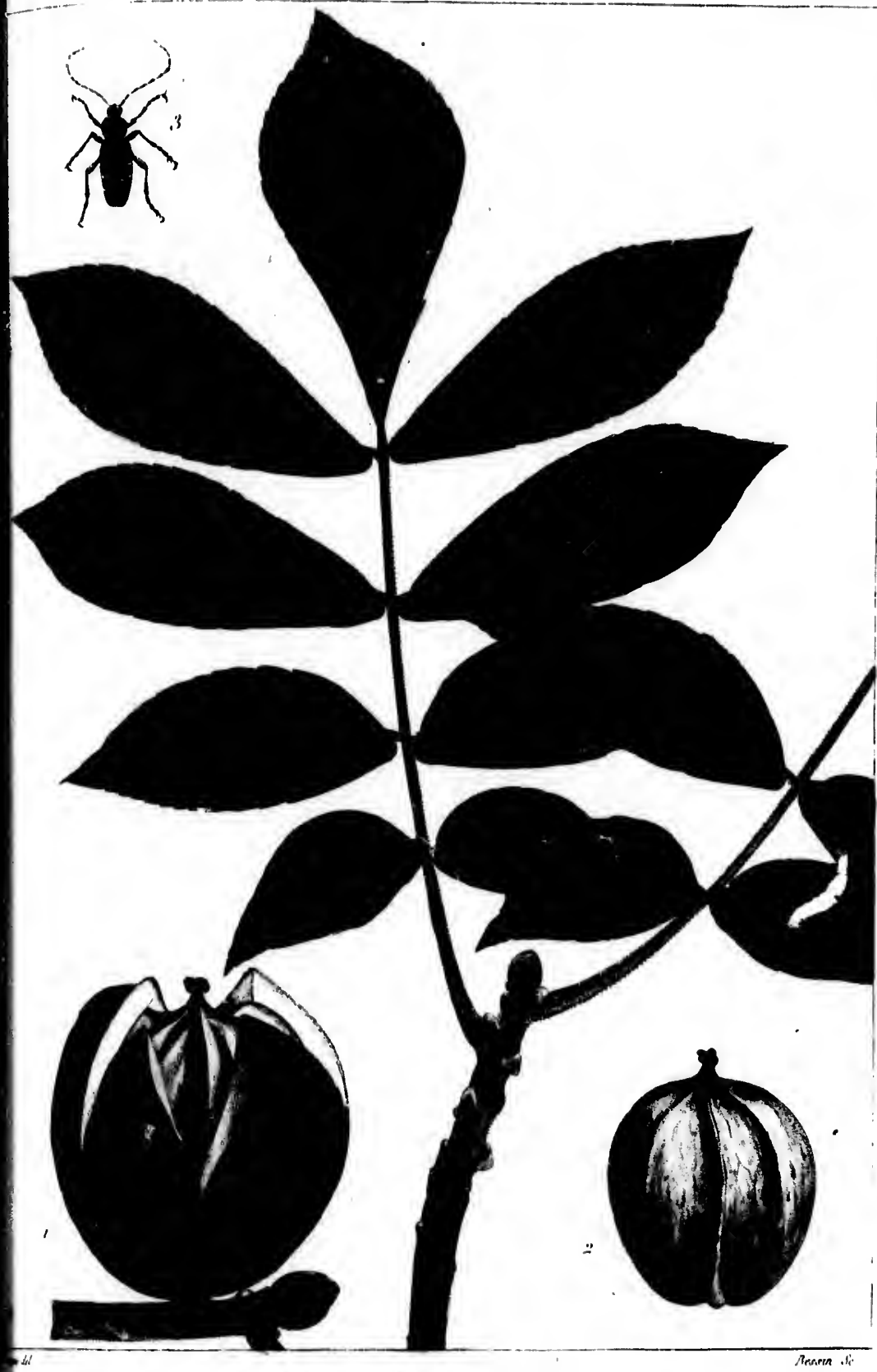

Mocker Nut Hickors.

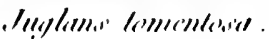




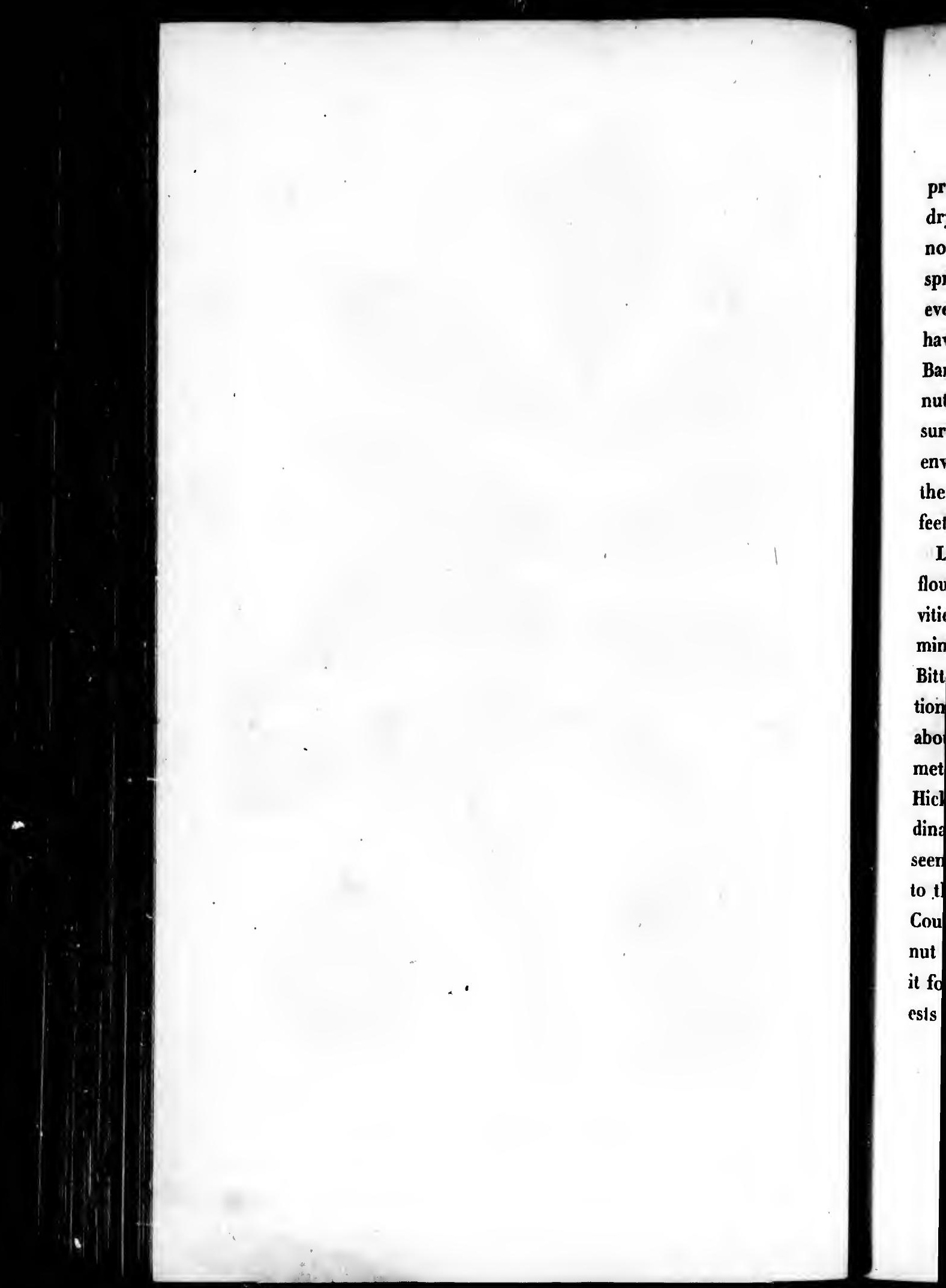


proaching the sea, as the sterility of the soil, in general dry and sandy, is unpropitions to its growth. I have noticed, however, that this is the only Hickory which springs in the Pine Barrens : the sprouts are burnt every year, and never rise higher than 3 or 4 feet. I have made the same observation, in traversing the big Barrens of Kentucky and Tennessee, where the Mockernut Hickory and Black Jack Oak alone are seen. They survive the conflagrations, which almost every spring envelop the prairies, but their vegetation is checked by the fire, and they do not exceed the height of 8 or io feet.

Like most of the Walnuts, the Mockernut Hickory flourishes in rich soils, and chiefly on the gentle acclivities which surround the swamps, where it grows, mingled with the Sweet Gum, Poplar, Sugar Maple, Bitternut Hickory, and Black Walnut. In these situations it reaches its greatest size, which is commonly about 60 feet in height, and 18 or 20 inches in diameter. I remember to have seen larger Mockernut Hickories, near Lexington in Kentucky, but this extradinary growth in several species of trees, is rarely seen on this side of the Alleghany, and is attributable to the extreme fertility of the soil, in the Western Country. Of all the Hickories, however, the Mockernut succeeds best on lands of a middling quality; for it for forms a part of the waste and impoverished forests, which cover the meagre sandy soil of Lower 
Virginia ; though under these disadvantages it exhibits but a mean and stunted appearance.

The buds of this species are large, short, of a greyish white, and very hard; in the winter, after the falling of the leaf, they afford the only characteristic by which the tree can be distinguished, when it exceeds 8 or 10 feet in height. In the beginning of May , the buds swell, the external scales fall off, and the inner ones soon after burst and display the young leat. The leaves grow so rapidly that I have seen them gain 20 inches in eighteen days. They are composed of 4 pair of sessile leaflets, and terminated by an odd one. The leaflets are large oval-acuminate, serrate, prety thick, and hairy underneath, as is also the common petiole to which they are attached. With the first frosts, the leaves change to a beautiful yellow and fall soon after. The barren flowers appear on pendulus, downy, axillary aments, 6 or 8 inches long; the fertile flowers which are not very conspicuous, are of a pale rose colour, and are situated at the extremity of the young shoots.

The fruit is ripe about the $15^{\text {"1 }}$ of November. It is odorous, sessile or rarely pedunculated, and commonly united in pairs. In form and size, it exhibits remarkable varieties : on some trees it is round, with depressed ceams, on others oblong, with augular or prominent seams; it is sometimes 2 inches long and 12 or 15 lines in diameter, and sometimes of less than half this size. It differs also in weight, as well as in configuration and

rolu nuts Shell Pign the $\mathrm{I}$ what sweet of th bably also,

The with : the sa and $c$ class o for fu diamet while $t$ is not of Wh colour not ext

Of al growth of the their at that it especial 
rolume, varying from one dram to four. The largest nuts might be contounded with those of the Thick Shellbark Hickory, and the smallest, with those of the

greyish e falling y which 8 or 10 ds swell, ies soon ves grow nches in of sessile e leaflets ick, and cetiole to the leaves ifter. The , axillary ers which lour, and bts. ber. It is ommonly remarkadepressed prominent r 15 lines f this size. ration and Pignut Hickory : I have selected for the drawing 2 nut of the most common size. The shell is very thick, somewhat channeled, and extremely hard. The kernel is sweet but minute, and difficult to extract, on account of the strong partitions which divide it : hence, probably, is derived the name of Mockernut, and hence also, this fruit is rarely seen in the markets.

The trunk of the old Mockernut Hickory is covered with a thick, hard, and rugged bark. Its wood is of the same colour and texture, with the other Hickories, and characterised by the qualities which render this. class of trees so remarkable. It is particularly esteemed for fuel, for which use, trees of 6 or 8 inches in diameter are preferred At this stage of its growth, while the heart, the proper colour of which is reddish is not yet developped, it frequently goes by the name of White heart Hickory. In the country, a greenish colour is sometimes extracted from the bark, but it is not extensively in use.

Of all the Hickories, this species is of the slowest growth : a fact which I have proved by planting nuts of the several species, and by comparing the length of their annual shoots. I have also been led to believe, that it is the most liable to be attacked by worms, and especially by the Callidium flexuosium, whose larva eats 
180

Mockearut mickont.

within the body of the tree. These considerations appears sufficiently weighty, to induce cultivators, in forming large plantations, to prefer some of the species which are described in the sequel.

\section{PLATE XXXV.}

'A leaf of a thind of its natural size. Fig. 1, 'A nut with its husk. Fig. 2, A nut without its husk. Fig. 3, Callidium Alexwosum. 



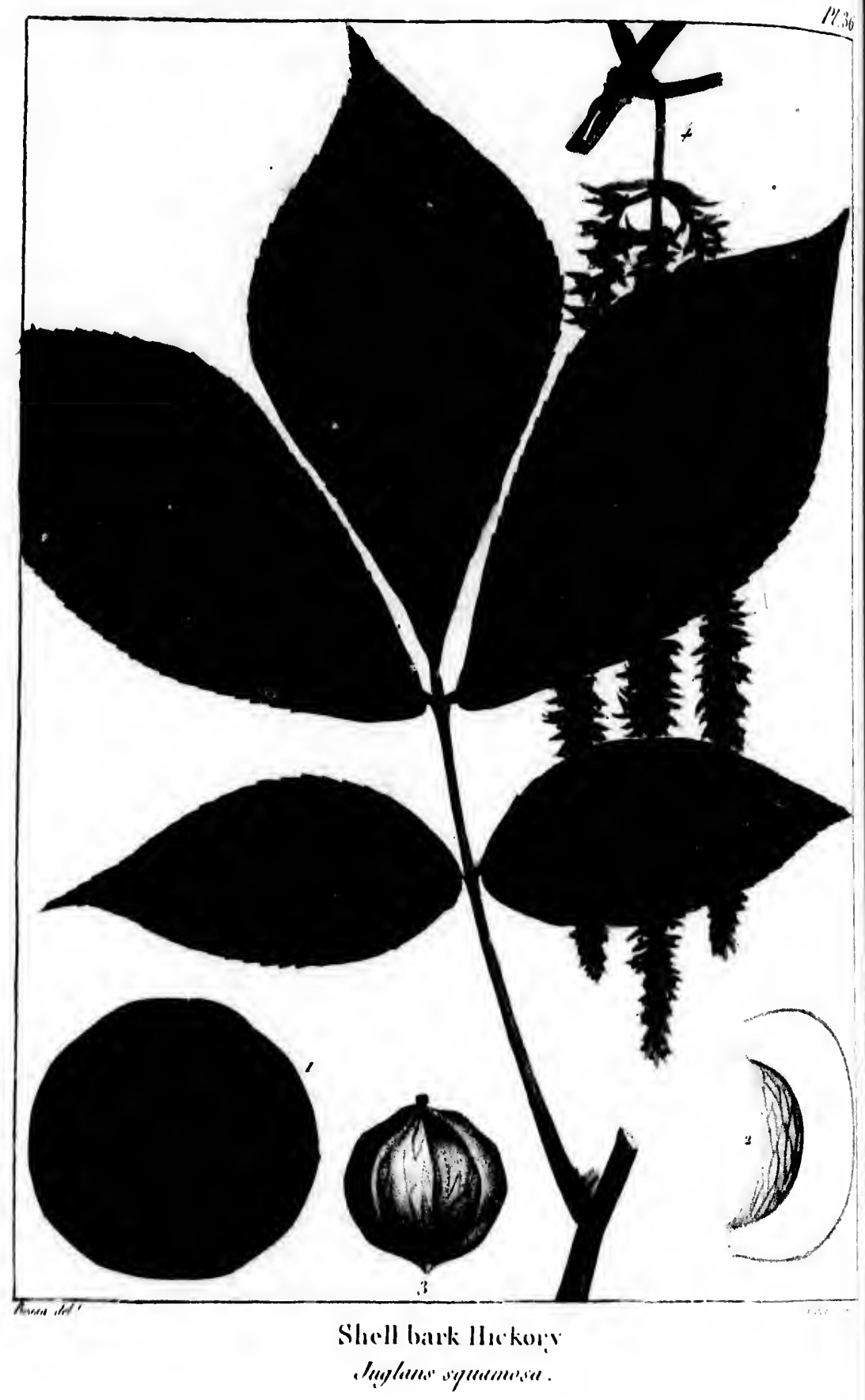

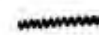

JUGLA

petio

imp

filifo

pres.

The

has gi

Shagb

being

states,

settler

the cit

the Fr

tendre,

Bey

observ

vegeta

its stat

it in $t$

of Ver

It abo

in Ger

hood

the $S_{1}$ 


\section{SHELLBARK HICKORY.}

Jugrans squamosa. J. foliolis quinis, majoribus, longè petiolatis, opato-acuminatis, serratis, subtìs villosis, impari sessili; amentis masculis, compositis, glabris, filiformibus : fructu globoso, depresso, majore; nuce compressâ, albâ.

THE singular disposition of the bark, in this species, has given rise to the descriptive names of Shellbark, Shagbark, and Scalybark Hickory, the first of which as being most generally in use in the middle and southern states, I have adopted. Many descendants of the Dutch settlers, who inhabit the parts of the of New Jersey near the city of New York, call it Kisky Thomas nut, and the French of Illinois, know it by the name of Noyer tendre, or Soft Walnut.

Beyord Portsmouth in New Ifampshire, I have not observed the Shell bark Hickory; and even there, its vegetation being impeded by the rigours of the climate, its stature is low, and its fruit small. I have not found it in the forests of the District of Maine, nor in those of Vermont, situated a little higher towards the North. It abounds on the shores of Lake Eric, about Geneva in Genesce, along the Mohawk river, in the neighbourlood of Goshen in New Jersey, and on the banks of the Susquehannah and Schuylkill rivers in Penusylva- 
nia. In Maryland, in the lower parts of Virginia, and in the other southern states it is less common. In South Carolina, I have nor noticed it nearer Charleston than the parish of Goose-Creek about 24 miles distant. It is met with in the Western States, but not as frequenthy as the following species, the Thick Shellbark Hickory, to which it bears a striking analogy, and with which it is confounded by the inhabitants. East of the Alleghanies, the Shellbark Hickory grows almost exclusively about swamps and wet grounds, which are exposed to be inundated for several weeks together: in these situations, it is found in company with the Swamp White Oak, Red flowering Maple , Sweet Gum, Buttonwood and Tupelo. Of all the Hickories, this species grows to the greatest height with proportionally the smallest diameter, for it is sometimes seen 80 or 90 feet high, and less than 2 feet thick. The trunk is destitute of branches, regularly shaped, and of an almost uniform size for three quarters of its length, thus forming a very fine tree. The greatest peculiarity in its appearance, and that by which it is most easily distinguished, is the surface of the trunk. The exterior bark is divided into a great number of long, narrow plates, which bend outwards at the ends, and adhere only in the middle. Bristling in this manner with projecting points, the Shellbark Hickory attracts the attention of the most careless observer. This remarkable exfoliation of the epidermis takes place, only in trees which

indicat tree $\mathrm{m}$ leaves, its gro confou Hickor two sp formed the spe scales a leave $t$ ? jecture, pricula so."

the sal fill, a with a buds, birth tt is so ra] which inches. sil odd nate , barren from th precedi 
nia, and

In South

harleston

distant. It

frequen-

bark Hic-

and with

ast of the

lmost ex-

which are

gether: in

with the

weet Gum,

$s$, this spe-

portionally ieen 30 or

le trunk is

d of an alpgth, thus rity in its sily distinerior bark ow plates, re only in projecting ttention of exfoliation ees which

exceed 10 inches in diameter, though it is much earlier indicated by seams. This characteristic, by which the tree may be recognised in winter when stript of its leaves, does not exist during the 7 or 8 first years of its growth; and during this period, it may easily be confounded with the Mockernut Hickory and Pignut Hickory, if recourse is not had to the buds. In these two species, and generally in all trees, the buds are formed of scales closely applied one upon another; in the species which we are considering, the two external scales adhere for only half the length of the bud, and leave the upper part uncovered. I allow myself the conjecture, that in this disposition of the scales, which is priciar to this and the following species, should be so." "e origin of the exfoliation of the bark. When the sap begins to ascendin the spring, the outer scales fall, and the inner ones swell and become covered with a yellowish silky down : after a fortnight, the buds, which are atready 2 inches long, open and give birth to the young leaves. The growth of the leaves is so rapid, that in a month they attain their full length, which on young and vigorous trees, is sometimes 20 inches. They consist of 2 pair of leaflets with a sessil odd one. The leaflets are very large, oval-acuminate, serrate, and slightly downy underneath. The barren flowers, which in the State of New York appear from the $15^{\text {th }}$ to the $20^{\text {th }}$ of May, are disposed as in the preceding species, on long, glabrous, filiform, pen- 
dulous aments, of which three are united on a common petiole, attached at the basis of the young shoots ; the fertile flowers, of a greenish hue and scar. 'cely apparent, are situated at the extremity. The fruit of the Shellbark Hickory is ripe about the beginning of October. Some years it is 'so abundant, that several bushels may be gathered from a single tree. It varies in size, according to the soil and the exposure in which it is produced, but five inches and a halt may be assumed as the average of its circumference. The shape is uniformly round, with four depressed seams, in which the husk opens at the season of perfect maturity, dividing itself completly into equal sections. The entire separation of the husk, and its thickness disproportioned to the size of the nut, form a character peculiar to the Shellbark Hickories. The nuts of this species are small, white, compressed at the sides, and marked by four distinct angles, which correspond to the divisions of the husk.

The Shellbark nut contains a fuller and sweeter kernel than any American Walnut, except the Pacanenut. The shell, though thin, must be cracked before being brought upon the table, as it is too hard to be crushed in the fingers like the European Walnut, which is certainly a superior fruit. These nuts are in such request, that they form a small article of commerce, registered on the list of exports of the products of the United States. This exportation, which does

not e: takes of $\mathrm{Co}$ India truit is marke lary a from been : I have Goshe 3n mil

The and $L$ the wi mortar vily m: their al

Befo cannot nuts, lill in any the with $r$ tury 0 species

I. 
not exceed four of five hundred bushels annually, takes place from New York and from the small ports of Connecticut, to the Southern States, to the West India Islands, and even to Liverpool ; where the truit is known by the name of Hickory nuts. In the market o' New York, they are sold at two dollars a bushel. They are gathered in the forests, and from insulated trees, which, in some places, have been spared in clearing the lands : a precaution which 1 have particularly noticed to have been used near Goshen in New Jersey, and on several estates about $3 n$ miles beyond Albany.

The Indians who inhabit the Shores of Lake Erie and Lake Michigan, lay up a store of these nuts for the winter, a part of which they pound in wooden mortars, and boiling the paste in water, collect the vily matter which swims upon the surface, to season their aliments.

Before speaking of the properties of the wood, I cannot forbear mentioning a fine variety of Shellbark nuts, produced upon a farm at Seacocus, near Snakeliill in New Jersey. They are nearly twice as large as any that $I$ have seen elsewhere, and have a white shell with rounded prominences instead of angles. A century of cultivation, perhaps, would not advance the upecies generally to an equal degree of perfection,

I. 24 
and probably this variety might still be improved by grafting.

The wood of the Shellbark Hickory possesses all the characteristic properties of the Hickories, 'being strong, elastic and tenacious. It has also their common defects of soon decaying and of being eaten by worms. As this tree stretches up to a great height with nearly an uniform diameter, it is sometimes employed at New York and Philadelphia for the keels of vessels; but it is now seldom used for this purpose, most of the large trees near the sea ports being already consumed. Its wood is found to split most easily and to be the most elastic ; for this reason it is used for making baskets, and also for whip-handles which are esteemed for their suppleness; several cases of them are annually exported to England. For the same excellence, and for the superior fineness of its grain it is selected, in the neighbourhood of New York and Philadelphia, for the back-bows of Windsor chairs, which are wholly of wood. I have frequently observed that among the Hickory wood brought to New York for fuel, this species predominated.

Such are the uses to which the Shellbark Hickory appears peculiarly adapted. It has before been seen to be tree of lofty stature and of majestic appearance : I should therefore recommend its introduction into the European forests, where it should be con- 
sazThBAR GrGKonx.

187

signed to cool and humid places, congenial with those in which f to flourishes in America. In the North of Europe it could not fail of succeeding, as it securely braves the extremest cold.

PLATE XXXVI.

Fig. I, A mut with its husk. Fig. 2, A section of the husk. Fig. 3, A nut without its husk. Fig. 3, A barren ament disided into three parts.

. 


\section{THICK SHELLBARK HICKORY.}

Juglans laciniosa. J. folïs mejonibus, $7-9^{\text {nin }}$, opato. acuminatis, serratis, subtomentosis, impari, petiolato: fructu majore, ocato; nuce oblongd, crassd, mediocriter compress $d$.

This species bears a striking analogy to the preceding, and is frequently confounded with it by the inhabitants of the Western Country : some of them distinguish it by the name of 'Thick Shellbark Hickory, which should be preserved as its appropriate denomination. East of the Alleghanies this tree is rare, and is found only in a few places ; it grows on the Schuylkill river 30 or 40 miles from its junction with the Delaware, and in the vicinity of Springfield 15 or 20 miles from Philadelphia, where its fruit is called Springfield nut. It is also found in Glocester County, in Virginia, under the name of Glocester Walnut. These different deno. minations confirm my observation, that this species is little multiplied on the castern side of theAlleghany mountains; a fact of which $I$ became assured in travelling through the country. It abounds, on the other hand, in the bottoms which skirt the Ohio and the rivers which empty into it, where it unites with the Honey Locust, Black Maple, Hackberry, Black Walnut, Wild Cherry, White and Red Elm, Box Elder, White Maple, 


$$
t
$$


and But

which $\mathrm{C}$ grows $t$ support ned to $\mathrm{i}$ arranges it is divi are war the mid ilarly di cies the a lighter proper outer sc inner on leaves al observe in size, being of nine Shellbar the same er than pear, no shoots 0 large ova inches i lickory, 
and Button wood, to form the thick and gloomy forests which cover these vallies. Like the Shellbark Hickory it grows to the height of 80 feet, and its ample head is supported bJ a straight trunk, in diameter, proportioned to its elevation. The bark exhibits the same singular arrangement with that of the Shellbark Hickory : it is divided into strips from 1 to 3 feet long, which are warped outwards at the end, and attached only in the middle. They fall and are succeeded by others similarly disposed. It is only observable that in this species the plates are narrower, more numerous, and of a lighter colour; from which differences, I have thought proper to give it the specific name of laciniosa. The outer scales of the buds do not adhere entirely to the inner ones, but retire as in the Shelliark Hickory. The leaves also, which vary in length from 8 to 20 inches, observe the same process in unfolding, and are similar in size, configuration, and texture; but they differ in being composed of seven lcaflets, and sometimes of nine instead of five, the invariable number of the Shellbark Hickory. The barren aments are disposed in the same form , though they are, perhaps, a little long er than in the other species. The fertile flowers appear, not very conspicuously, at the extremity of the shoots of the same spring. They are succeeded by a large oval fruit, more than 2 inches long, and 4 or 5 inches in circumference. Like that of the Shellbark Ilickory, it has four depressed seams, which at its com- 
plete maturity, open through their whole length for the escape of the nut. The nut of this species is widely dilferent from the other; it is nearly twice as big, it is longer than it is broad, and is terminated at each end in a firm point. The shell is also thicker and of a yellowish hue, while that of the Shellbark nut is white.

From the colour of its nut, the Shellbark Hickory received the specific name of alba, which I have changed, as it indicates a character possessed by it in common with another species, found in the Royal gardens of the Petit Trianon. This species, originally from North America, belongs to the Scalybark Hickories. The nuts are white, and the entire fruit, though a little inferior in size, resembles that of the proper Shellbark Hickory. By its foliage, it is related to the Thick Shellbark Hickory, each leaf being composed of 4 pair of leaflets with an add one. The specific name of ambigisa, might with propriety be given to it.

The nuts of the Thick Shellbark Hickory are brought every autumn to the market of Philadelphia, but the quan. tity does not exceed a few bushels, and they are generally sold mixed with those of the Mockernut Hickory, which resemble some varieties of this species. The GlocesterHick. ory I consider only as a varicty of the Thick Shellbark Hickory, to which it bears the strongest likeness in its appearance, in its young shoots, in the number of its leaflets, and in its barren aments. The only essential difference is in the nuts; those of the Glocester Walnut

are a th so hard to cracl Mocke: they $\mathbf{m}$ The nearly which peculiar commo inferior prietor lands, ence, soil. For in less a fact $w$ Allegha be gives In th been se semblar into a specific themsel were it be trea of the 
are a third larger, with the shell one half thicker, and so hard that it requires pretty heavy blows of a hammer to crack them. In colour, they resemble the nuts of the Mockernut Hickory, with the finest varieties of which, they might from this circumstance be confounded.

The Thick Shellbark Hickory, as has been said, is nearly related to the Shellbark Hickory, and its wood, which is of the same colour and texture, unites the peculiar qualities of that species, with such as are common to the Hickories. Its fruit, though larger, is inferior in taste and this consideration should induce proprietors in the Western Country, in clearing their new lands, to spare the true Shellbark Hickory in preference, when both species are found upon the sams. soil. For the same reason, and for its favourable grow:h in less fertile grounds, and even in elevated situations, a fact which I have observed near Brownsville on the Alleghany river, the same preference should, I think, be given to it in the forests of Europe.

In the description of the Scaly bark Hickories it has been seen, that they exhibit many striking traits of resemblance, which may warrant the grouping of them into a secondary section. Besides their maneric and specific characters, they possess others peculiar to themselves, by which they are so nesily related, that were it not for some remarkable liferences, they might be treated as a single species. The general characters of the Hickories are, three-clefted, pliable, and pen$s$ in itsapber of its y essential er Walnut 
dulous barren aments, and certain common properties of the wood. To these are added in the Scaly Hickories, a very thick husk covering the nut completely, and divided into four parts when ripe; a shaggy bark on the trunk, indicated, in my opinion, by the external scales of the buds not adhering to those beneath; and leaves composed of very large leaflets of an uniform shape and texture. In comparing the three species with each other, essential differences are observed. The Shellbark Hickory, for instance, and the Juglan' ambigua are constantly distinguished by the num. ber of leaflets, which is always five in the first species, and nine in the last. Their nuts and the entire fruit, on the other hand, are so much alike, that they might be mistaken for the product of the same tree; the fruit of both is round with depressed seams, and the nuts are similarly moulded and equally white. If, on a more attentive examination, the Glocester Hickory is determined to be a distinct species from the Thick Shellbark Hickory, it will be observed that they resemble each other in their leaves, composed of seven and sometimes of nine leaflets, and in the luxuriant force of their vegetation; but that they differ in their fruit, which in the Thick Shellbark Hickory is oblong with a compressed nut, like that of the Shellbark Hickory, of twice the size, and of a yellowish colour, and in the Glocester Hickory spherical and very large, with a big, greyish white 
TAICX SHELLAAR GICKOBX.

nut, nearly round, whose shell is two lines thick and extremely hard. In fine, it is to be remarked, that the species and the variety of the Scalybark Hickory which have been described, grow, or at least, are most abundantly multiplied in regions far remote from each other.

\section{PLATE XXXVII.}

$A$ leaf of one third of its natural size. Fig. $x, A$ section of the husk. Fig: 2, Nuts. 


\section{PIGNUT HICKORY.}

Juglirs poncisa. J. foliolis $5-7^{\text {nis, }}$ ovato-acuminatis, serratis, glabris : amentis masculis compositis, fliformibus, glabris ; fructu pyriformi vel globoso ; nuce minimd, levi, durissima.:

Tris species is generally known in the United States by the name of Pignut and Hognut Hickory, sometimes also by that of Broom Hickory. The first of these names is most commonly in use; the others are known only in some districts of Pennsylvania and particularly in the County of Lancaster. Portsmouth in New Hampshire may be considered as limiting towards the north, the climate of this tree. A little farther south it is abundant, and in the Atlantic parts of the middle States, it helps, with the Mockernut Hickory, White Oak, Swamp white Oak, Sweet Gum, and Dogwood, to form the mass of the forests. In the Southern States, especially near the coast, it is less common in the woods, being found only on the borders of swamps and in places which are wet without being alsolutely marshy, or exposed to be long inundated. This tree is met with in the Western Country, but less fiequently, I believe, than the Thick Shellbark and Mockernut Hickories. I have observed that the last mentioned species grows wherever the 



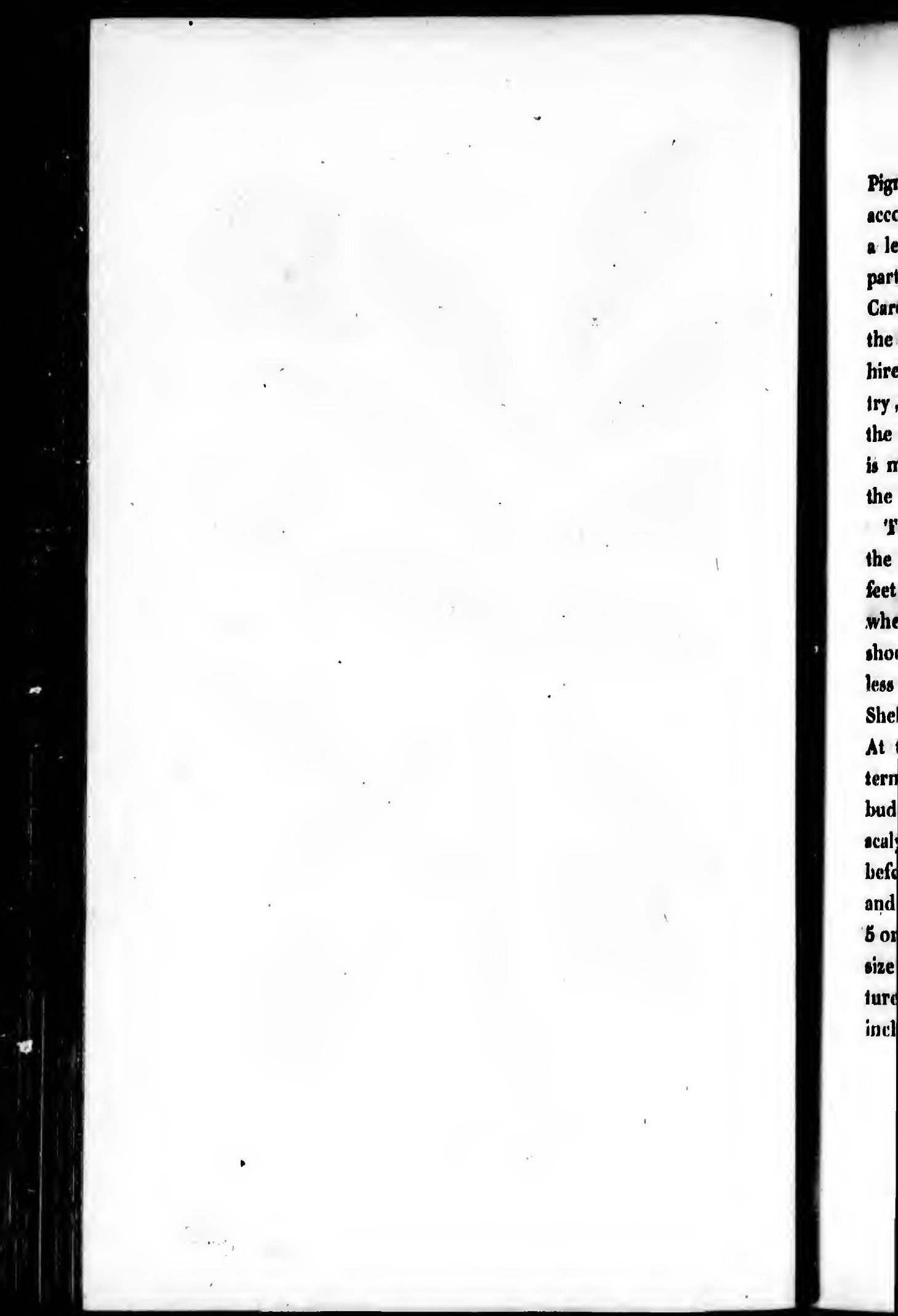


Pignut is found, but that the Pignut does not always accompagny the Mockernut, which is satisfied with a less substantial soil. This remark I have made more particularly in the lower parts of Virginia, of the two Carolinas, and of Georgia. If appears then, that, with the exception of States of Vermont and New Hampshire, of the District of Maine, of the Genesee Couniry, and of the cold and mountainous tracts along the whole range: of the Alleghany mountains, this tree is more or less abundant in the forests; throughout the United States.

'The Pignut: Hickory is one of the Iargest trees of the United States. It grows to the height of 70 or 80 feet, with a diameter of 3 or 4 feet. In the winter when stript of its leaves, it is easily known by the shoots of the preceding summer, which are brown, less than half as large as: those of the Mockernut $i$ and Shellbark Hickories, and terminated by small oval buds. At this season, it is easy also to distinguish the Bitternut Hickury; by its naked and yellow buds. The buds of this species; as in the other Hickories with acaly buds, are more than an inch in length, a few days before their unfolding. The inner scales are the largest and of a reddish colour. The do.not fall till the leaves are $b$ or 6 inches long. The leaves are compound, and vary in size and in the number of leaflets, according to the moisture and fertility of the soil. In rich grounds, they are 18 inches long; and the complete number ofleaflets is 3 pair 
with an odd one. The leaflets are 4 or 5 inches long, acuminate, serrate, nearly sessile, and glabrous or smooth on both sides. On vigorous trees, which grow in shady exposures, the petiole is of a violet colour.

The barren aments are smonth, filiform, flexible, and pendulous: they are 2 inches long, and in their arrangement, resemble those of the other Hickories. The fertile flowers are greenish, not very conspicuous, and situated at the extremity of the shoot : the fruit succeeds them in pairs as often as single. The husk is thin and of a beautiful green : when ripe, it opens through half its length, for the passage of the nut. The nut is small, smooth, and very hand on account of the thickness of the shell. Its kernel is sweet but meager. and difficult to extract, from the firmness of the partitions. These nuts are never carried to market, but serve for food to swine, racoons, and the numerous species of squirrels which people the forests.

In the Pignut Hickory, the form and size of the nuts, vary more than in the other species. Some are oval, and when covered with their husks, resemble young figs; others are broader than they are long, and others are perfectly round. Among these various forms, some nuts are as large as the thumb, and others not bigger than the little finger. Although the same tree yields fruit of the same form every year, I cannot; after an attentive examination of the young shoots and of the aments, consider these differences in any other light than as va- 
hes long, abrous or hich grow et colour. , flexible, $d$ in their Hickories. ispicuous, : the fruit he husk is is through The nut is the thickeager. and partitions. $t$ serve for species of

the nuts, are oval, roung figs; others are some nuts igger than ds fruit of attentive ce aments, than as va- rieties. The two most remarkable of them are described in the new edition of the Species plantanim by Willdenow, as distinct species. That with oblong fruit: is called Juglans glabra, and that with round fruit and a husk somewhat rough, Juglans obcordata. Doctor Muhlenberg admits this distinction, but with all the deference which I owe to his botanical knowledge, I cannot adopt his opinion.

The wood of the Pignut Hickory resembles that of the other species, in the colour of its sap and of its heart : it possesses also their excellencies and theiv defects. I have conversed with wheel-wrights in the country, who affirmed that it is the strongest and the most tenacious: of the Hickories, and who, for that reason, preferred it to any other for axle-trees and ax-handles. These considerations lead me to recommend its introduction into the forests of Europe, where its success would be certain.

\section{PLATE XXXVIII.}

$A$ branch with its leaves of one third of the natural size. Fig. I, $A$ vut with its husk (oblong variety). Fig. 2, $A$ nut without its husk. Fig. $3, A$ nut with its husk (round variety). Fig. 4, A nut woithout its husk. 


\section{NUTMEG HICKORY.}

Jugrans MYRIstrcaronmis. J. folius quinis, foliolis ovato acuminatis, serratis, glabris : fructu ovato, scabriusculo; nuce minima, durissimá.

No specific denomination has hitherto beel given to this species by the inhabitants the Middle States, to which it is peculiar : that of Nutmeg Hickory which I have formed appears sufficiently appropriate, from the resemblance of its nut to a nutmeg.

I have not myself found this tree in the forets, and hence $I$ conclude that it is not common. It is true I had not, at the period of my residence in that part of the United States, conceived the design of the present work, and did not devote myself entirely to the researches, which have since given birth to it. I am acquainted with the Nutmeg Hickory only by a branch and a handfull of nuts, given me at Charleston in the fall of 1802 by the gardener of $M^{*}$. H. Izard, which he had gathered, in a swamp on his master's plantation of the Elms, in the Parish of Goose creek. From this specimen alone I have included the tree among the Hickories.

The leaves, which are composed of four leaflets with an odd one, are symetrically arranged. I remarked also, that the shoots of the preceding year were flexibli and tough. 


$$
\text { 䎹 }
$$


The nuts are very small, smpoth, and of a brown color marked with lines of white; the husk is thin and somewhat rough on the surface. The shell is so thick that it constitutes two thirds of the volume of the nut, which, consequently, is extremely bard, and has a minute kernel. This fruit is still inferior to the Pignut.

I suspect that the Nutmeg Hickory is more common in Lower Louisiana * : it belongs to inquirers who engage in researches analogous to those which I have pursued in the Atlantic and Western States, to study this tree more fully than I have been able to do, and to complete the imperfect description which I have given of it:

\section{PLATE XXXIX.}

A branch and nuts with their husks. Fig. I, A nut without ils husk.

* In the interesting work of Mr. W. Darby on Louisiana, published at Philadelphia in 1817 , the Nutmeg Hickory is said to abound on the waiers of Red river in the Mississipi Territory.

F. A. $M$. 


\section{RECAPITULATION \\ OF THE PROPERTIES AND USES \\ OF HICKORY WOOD.}

Ix the summary introduction to the History of the Walnuts of North America, it was remarked, that those of the second section, or the Hickories, exhibit great variations in the size and shape of their fruit, in the number of leaflets which compose their leaves, and in their general appearance, from the elfect of soils of different degrees of moisture. Hence result, in many cases, mutual resemblances so striking, that a person not familiar with this class of trees, might easily confound distinct species, or describe as different species what are mere varieties. On taking of the epidermis or dead part, the same organisation is observed in the bark of all the Hickories. In other trees the fibre and the cellular substance are confounded; here, on the contrary, they are separate, and the fibre is regularly disposed in the form of 10 zenges, which are smaller in young trees, than in such as are more fully grown. An arrangement so peculiar and remarkable has a beautiful effect, and great advantage might be taken of it in cabinet-making, if this bark was not , like other species, liable to warp. It affords nevertheless an interesting object in vegetable physiol- 
ogy. So close an analogy exists in the wood of these trees, that when stript of the bark, no difference is discernible in the grain, which is coarse and open in all, nor in the colour of the heart, which is uniformly reddish. To these conspicuous properties are added others worthy of remark, which, as has been observed, though moditied in the several species, are possessed by them all in a higher degree, than by any other trce of the same latitude in Europe or America. These are great weight, strength, and tenacity, a speedy decay when exposed to heat and moisture, and peculiar liability to injury from worms. According to these prominent excellencies and defects, the uses of their wood are pretty well determined; and to these uses they are indiscriminately applied.

Hickory timber is employed in no part of the United States in the building of houses, because, as has been before observed, it is too heavy, and soon becomes worm eaten. But if its defects forbid its employment in architecture, its good qualities, on the other hand, render it proper for many secondary uses, which could not be as well subserved by any other wood.Throughout the Middle States; it is selected for the axle-trees of carriages, for the handles of axes and other carpenter's tools, and for large screws, particularly those of bookbinder's presses. The cogs of mill-wheels are made of Hickory heart thoroughly seasoned ; but.it is proper only for such whecls as are not exposed to moisture; and for I. 26 
this reason some other wood is, by many mill-wrights, preferred. The rods which form the back of Windsor chairs, coach-whip-handles, musket-stocks, rake-teeth, flails for threshing grain, the bows of yokes, or the elliptical pieces which pass under the necks of the cattle; all these are objects customarily made of Hickory. At Baltimore it is used for the hoops of sieves, and more es is teemed than the White Oak, which is equally elastic, but more apt to peel off in small shreds into the substance silted. In the country near Augusta in Georgia, I have remarked that the common chairs are, of Hickory wood. In New Jersey it is employed for shoeing sledges, that is, for covering the runners or parts which slide upon the snow; but to be proper for this use it must have been cut long enough to have become perfectly dry.

Of the numerous trees of North America east of the Alleghany mountains, none except the Hickory is perfectly adapted to the making of hoops for casks and boxes. For this purpose vast quantities of it are consumed at home, and exported to the West India Islands. The hoops are made of young Hickories from 6 to 12 feet high, without choice as to the species. The largest hooppoles sold at Philadelphia and New York in February 1808, at three dollars a hundred. Each pole is split into two parts, and the hoop is crossed and confined by notches, instead of being bound at the end with twigs, like those made of Chesnut. From the solidity of the wood, this method appears sufficiently secure. 
wrights, preIdsor chairs, th, flails for the elliptical tle ; all these r. At Baltiid more es is y elastic, but he substance orgia , I have ickory wood. dges, that is, ide upon the st have been dry.

a east of the ckory is peror casks and it are consuIndia Islands. In 6 to 12 feet largest hoopin February e is split into confined by d with twigs, lidity of the ure.
When it is considered how large a part of the productions of the United States is packed for exportation in barrels, an estimate may be formed of the necessary consumption of hoops. In consequence of it, young trees proper for this object have become scarce in all * parts of the country which have long been settled The evil is greater, as they do not sprout a second time from the same root, and as their growth is slow. The cooper can not lay up a store of them for future use, for unless employed within a year, and often within six months after being cut, they are attacked by two species of insect; one of these, which eats within thewood; and commits the greatest ravages, is represented on the plate of the Mockernut Hickory, the wood of which species I have observed to be peculiarly liable to its attacks.

The defects which unfit the Hickory for use in the building of houses, equally exclude it from the construction of vessels. At New York and Philadelphia, the Shellbarka nd Pignut Hickories have been taken for keels, and are found to last as long as those of other wood, owing to their being always in the water. Of the two species, the Pignut would be preferable as being less liable to split, but it is rarely found of as large dimensions as the other.

In sloops and schooners the rings by which the sails are hoisted and confined to the mast, are always of Hickory. I have also been assured, that for atlaching the 
cordage it makes excellent pegs, which are stronger than those of Oak: but they should set loosely in the holes, as otherwise for want of speedily seasoning, they soon decay. For handspikes the Hickory is particulary esteemed on account of its strength : it is accordingly empioyed in most American vessels, and is exported for the same purpose to England, where it sells from 50 to roo per cent higher than Ash, which is brought also from the North of the United States. The Hickories are cut without distinclion for this use, but the Pignut, I believe, is the best.

All the Hickories are very heavy, and in a given volume contain a great quantity of combustible matter. They produce an ardent heat, and leave a heavy, compact, and long lived coal. In this respect, no wood of the same latitude, in Europe or America, can be compared to them : such, at least, is the opinion of all Europeans who have resided in the United States. At New York, Philadelphia and Baltimore, people in easy circumstances, burn no other wood, and though it is sold 5o per cent higher than Oak, it is found profitable in use. It sold at New York the $20^{\text {th }}$ of october 1807 at 15 dollars a cord, and Oak wood at 10 dollars. From ils superior quality, the Hickory is always sold separately. I liave noticed that at New York, the Shelliark predominated in the fuel, and at Philadelphia and Ballimore, the Mockernut. At Baltimore the Shellbark; easily recognised by its scaly bark, is never seen. 
The quantity of the respective species of Hickory consumed in the cities, is regulated by a soil and climate, more favorable to one than another, and not by an opinion entertained of their comparative excellence; though experierce shews the Mockernut to be the best and the Bitteruut the poorest. This difference, however, is too slight to be generally regarded.

of the uses to which the Hickory is devoted in the United States, two will principally contribute, together with the slowness of its growh, to its entire extermination ; these are, the cutting of the saplings for hoops, and of the trees for fuel. These considerations independanily of many accessory causes, which hasten the destruction of the forests in this part of the new world, lead me to believe, that in lest than 50 years, they will not furnish a tenth part of the hoops demanded in commerce. Ilence arise motives sufficiently powerful to engage proprietors, who seek to preserve their woods, and to augment their value, to multiply in them the most useful trees, and especially the Hickories. The object might be fully attained by planting walnuts, previously made to germinate in boxes filled with earth, and kept moist in the cellar : the success of this simple method is certain. It would be advantageous also, to plant a greater number than the soil can sustain, that when the poles are an inch in diameter, a part of them may be cut for hoops, while the rest are left to grow for fuel, or for other uses to which the Hickory is appropriate. 
It has been seen by what orecedes, that though the Hickory wood has essenti, ${ }^{\prime}$ efects, they are compensated by good properties which render it valuable in the arts, and which entitle it to the attention of It peans; above all, as a combustible. Though its. rowth is slow during its early y it should form a part of our forests. But I doabt wher this can be effected except by planting nuts in the woods, for the trees, even when very young, with difficulty survive transplan. tation. Before they are 3 lines in diameter and 18 inches tall, they have a tap root 3 feet long and destitute of fibres, Hence it has happened, that of more than a hundred thousand joung plants, produced by nuts which I have at different times sent to France, very few are found alive. They have perished in the removal from the nursery, or in the second transplantation to the place of their ultimate destination. The Black Walnut and Bitternut, on the contrary, whose roots do not descend deeply and are plentifully garnisherl with fibres, easily recover themselves after transplintation, even when 6 or 8 feet high at the time of their removal.

In concluding this article I recommend particillary for propagation in European forests the Shellhark Hickory and the Pignut Hickory, whose wood unites in the highest degree the valuable properties of the group. I think also that the Pacanenut merits attention from promoters of useful culture, not so much for its wood as for its fruit, which is excellent and more deli- 
RzCapituratron.

207

cate than that of the European Walnut. It might probably be doubled in size, if the practice was successfully. adopted of grafting this species upon the Black Walnut or upon the Common European Walnut. 


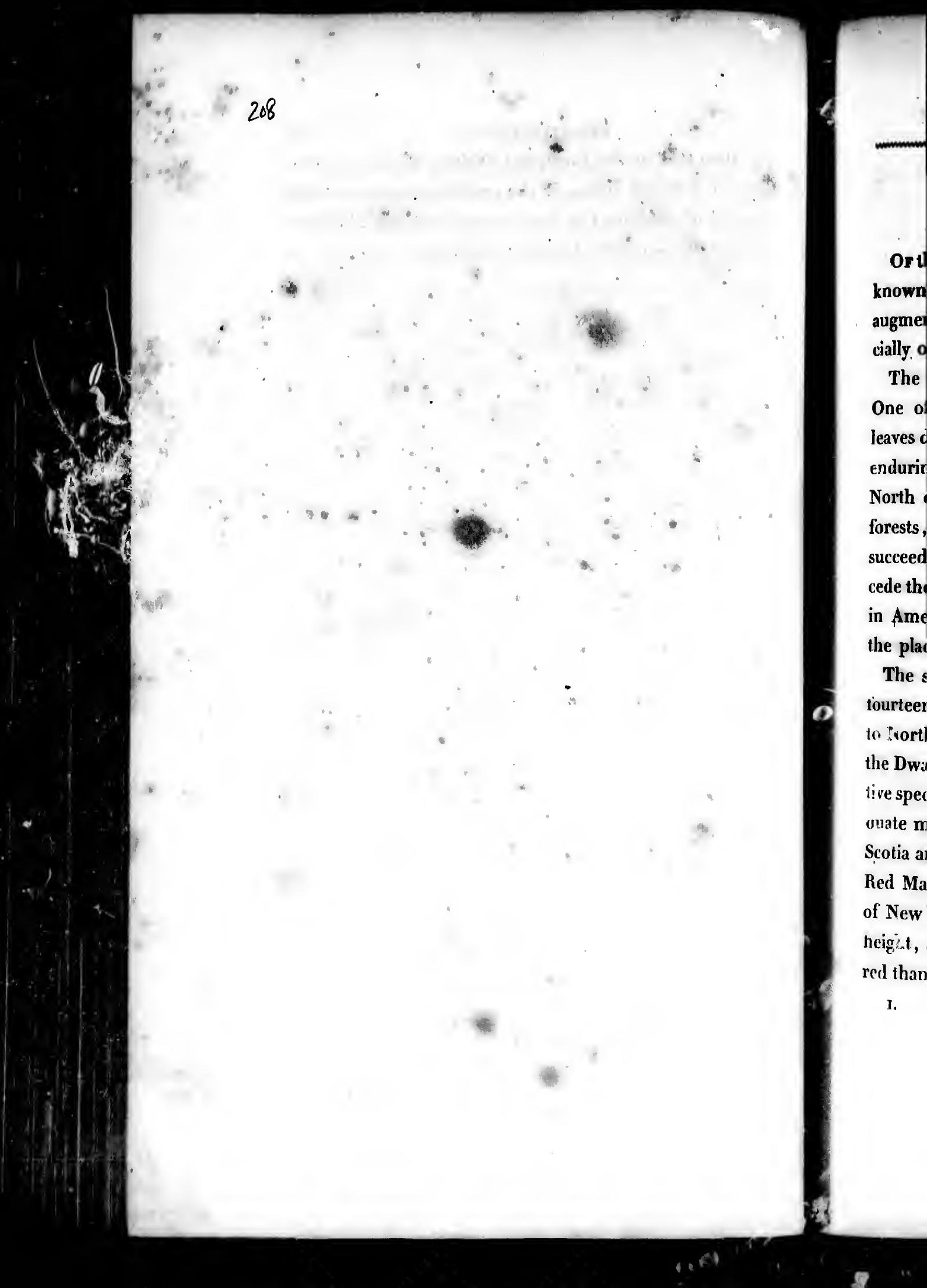




\section{9.}

\section{MAPLES.}

Or the species which compose this genus, the number known is already considerable; and will probably be augmented by the future researches of Botanists, especially on the continent of North America.

The Maples, in general, are lofty and beautiful trees. One of their principal characters consists in opposite leaves divided into several very distinct lobes. Capable of enduring an intense degree of cold, they form in the North of the Old and of the New continent, extensive forests, which, with those of the Beech, appear to succeed the Spruce, the Larch, and the Pine, and to precede the Chesnut and the Oak. Such,at least, seems to be in America between the 43 and 46 degrees of latitude, the place assigned by nature to the true Sugar Maple:

The species of Maples hitherto described amount to tourteen, of which seven belong to Europe, and seven to. Sorth America. Among these last I have not included the Dwarf Red Maple,Acer coccineum, which is a diminutive species, and concerning which I do not possess adeouate materials for a description. It abounds in Nova Scotia and has always been confounded with the proper Red Maple; I have also observed it in the upper parts of New Hampshire. It scarcely exceeds $i 2$ or 18 feet in height, and its flowers and seeds are of a more vivid red than those of the Red Maple. The Black sugar Maple

I. 
grows to about the same height with the Sugar Maple, but it is plainly a distinct species. In the collection of dried plants made by Cap to. Lewis and Clarke during their journey to the south sea, I saw specimens of a beantiful Maple from the banks of Columbia river.

From this brief summary it results that the North American species are more numerous than those of Europe. The wood of the Maples differs so widely in quality in different species, that it becomes difficult to characterize it by general observations : it may be remarked that it speedily ferments and decays when exposed to the weather, that it is liable to be injured by worms, and that hence, it is unfit for building. It possesses properties however, which compensate in part for these defects, and which render it useful in the arts and in domestic economy. For more particular information, I must refer the reader to the descriptions of the respective species. 
211.

zar Maple; llection of uring their a beautiful the North n those of 0 widely in difficult to be remar2 exposed to worms, and s properties ese defects, in domestic I must refer ative species.

\section{METHODICAL DISPOSITION OF THE MAPLES}

OF NORTH AMERICA,

INCLUDING TWO EUROPEAN SPECIES.

Polygamia dioecia, Lins. Acera, Juss. I.st SECTION.

Sessile flowers. Fructification vermal.

1. White Maple. . . . Acer eriocarpum.

2. Red flowering Maple. . Acer rubrum.

$$
\text { 2. }{ }^{\text {ad }} \text { SECTION. }
$$

Pedunculated flowers. Fructification autumnal.

3. Sugar Maple ..... . Acer saccharinum.

4. Black sugar Maple. . . . Acer nigrum.

5. Norway Maple. . . . . . Acer platanoides.

6. Sycamore........Acer pseudo-platanus.

7. Moose wood. ...... Acer striatum.

8. Box elder. . . . . . Acer negundo.

9. Mountain Maple... . Acer montanum. 


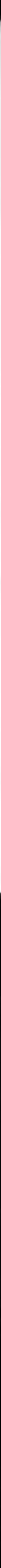




$$
-1
$$




$$
\rightarrow
$$




\section{IMAGE EVALUATION \\ TEST TARGET (MT-3)}
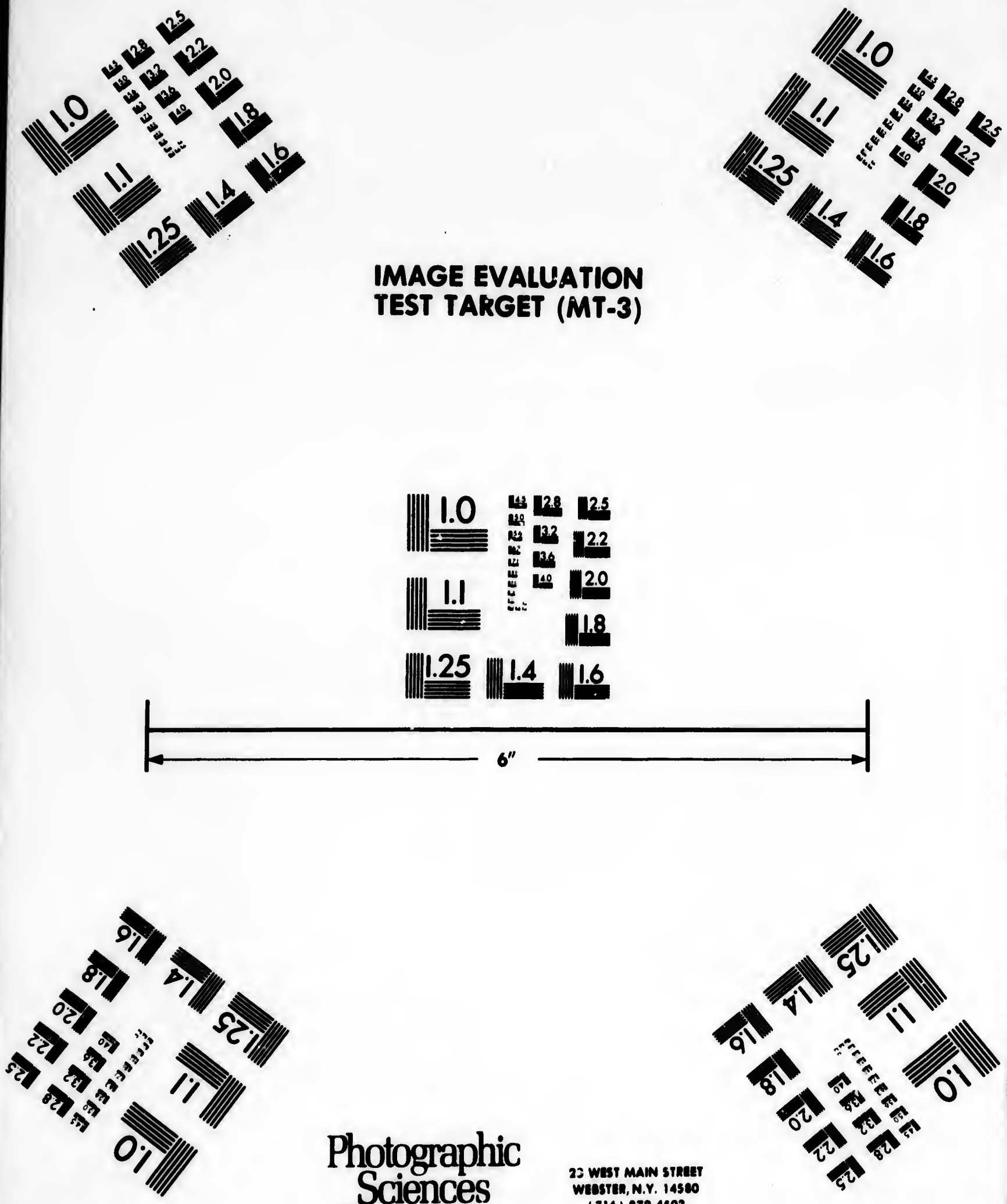

Photographic Sciences Corporation

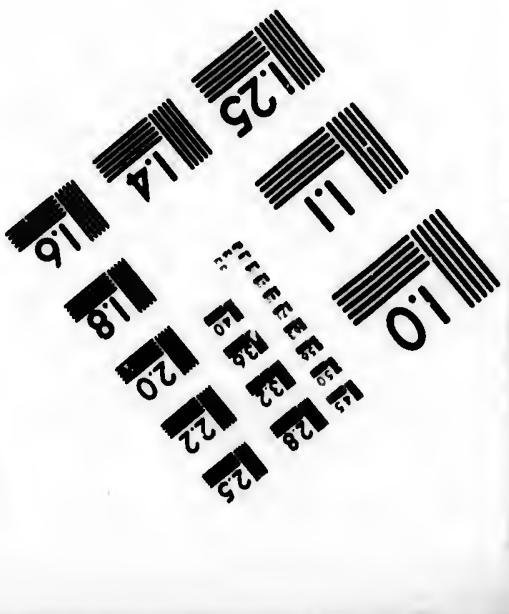




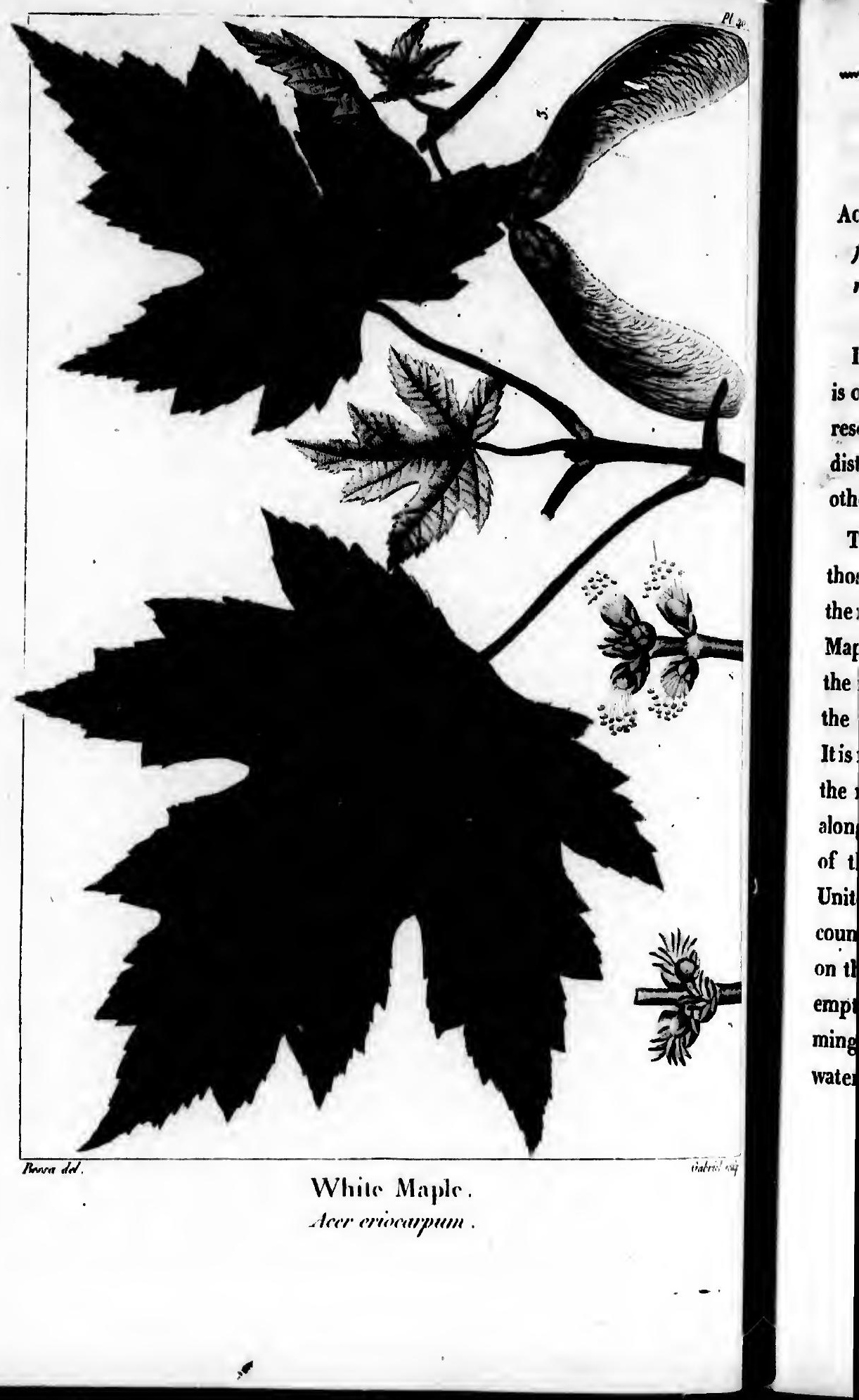




\section{$2 / 3$.}

\section{WHITE MAPLE.}

Aczr zntocanpum. A. foliis oppositis, quinquelobis, profunde sinwatis, inaequaliter dentatis, subtis candidissimis : floribus pentandris, apetalis.

Is the Atlantic parts of the United States, this species is often confounded with the Red Maple which it nearly resembles; west of the Mountains, they are constantly distinguished, and the Acer eriocarpum is known by no other name than White Maple.

The banks of Sandy river in the District of Maine, and those of the Connecticut near Windsor in Vermont, are the most northern points at which I have seen theWhite Maple. But, like many other vegetables, it is pinched by the rigorous winters of this latitude, and never reaches the size which it attains a few degrees farther south. It is found on the banks of all the rivers which flow from the mountains to the Ocean, though it is less common along the streams which water the southern parts of the Carolinas and of Georgia. In no part of the United States is it more multiplied than in the western country, and nowhere is its vegetation more luxuriant than on the banks of the Ohio, and of the great rivers which empty into it. There, sometimes alone, and sometimes mingled with the Willow, which is found along all these waters, it contributes singularly by its magnificent fo- 
214

WIITE MAPR.

liage to the embellishment of the scene. The brilliant white of the leaves beneath forms a striking contrast with the bright green above, and the alternate reflexion of the two surfaces in the water, heightens the beauty of this wonderful moving mirror, and aids in forming an enchanting picture, which, during my long excursions in a canoe in these regions of solitude and silence, I contemplated with unwearied admiration. Beginning at Pittsburgh, and even some miles above the junction of the Aleghany and Monongahela rivers, White Maples 12 or 15 feet in circumference are continually met with at short distances.

The trunk of this tree is low, and divides itself into a greatn umber of limbs so divergent, that they form a head more spacious than that of any other tree with which I am acquainted. It is worthy of remark, that the White Maple is found on the banks of such rivers only as have limpid waters and a gravell; bed, and never in swamps and other wet grounds inclosed in forests, where the soil is blark and miry. These situations, on the contrary, are so well adapted to the Red Maple, that they are frequently occupied by it exclusively. Hence the last mentioned species is common in the Lower parts of the Carolinas and of Georgia, where the White Maple is no longer seen; for as soon as the rivers, in descending from the mountains towards the Ocean, reach the low country, they begin to be bordered by miry swamps covered with the Cypress, Blackgum, Large Tupelo, etc. 
The White Maple blooms early in the spring ! its flowers are small and sessile with a downy ovarium. The fruit is larger than that of any other species which grows east of the Mississipi. It consists of two capsules joined at the base, each of which encloses one roundish seed, and is terminated by a large, membraneous, falciform wing. In Pennsylvania it is ripe about the Ito. of May and a month earlier on the Savannah river, in Georgia. At this period, the leaves which have attained half their size are very downy underneath ; a month later, when füly grown, they are perfectly smooth. They are opposite and supported by long petioles ; they are divided by deep sinuses into four lobes, are toothed on the edges, of 2 bright green on the upper surface, and of a beautiful white beneath. The foliage however is scattered and leaves an open thoroughfare to the sun beams.

The wood of this Maple is very white, and of a fine grain; but it is softer and lighter than that of the other species in the United States, and from its want of strength and durability it is little used. Wooden bowls are sometimes made of it when Poplar cannot be procured. At Pittsburgh, and in the neighbouring towns, it serves in cabinet-making, instead of Holly, for inlaying furniture of Mahogany, Cherry tree, and Walnut: though it is less proper for this purpose, as it soon changes colour. The hatters of Pittsburgh prefer the charcoal of this wood to every other for heating their boilers, as it affords a heat more uniform, and 
of longer continuance. Some of the inhabitants on the Ohio make sugar of its sap, by the same process which is employed with the Sugar Maple. Like the Red Maple, it yields but half the product from a given measure of sap ; but the unrefined sugar is whiter and more agreeable to the taste than that of the Sugar Maple. The sap is in motion earlier in this species than in the Suygar Maple, beginning to ascend about the $15^{\text {th }}$ of January ; so that the work of extracting the sugar is sowner completed. The cellular integument rapidly produces a black precipitate with sulphate of iron.

In all parts of the United States where this tree abounds, many others are found of superior value: its secondary consequence is evinced by the unim. portant uses to which it is devoted.

In Europe, the White Maple is multiplied in nurseries and gardens. Its rapid growth affords hopes of cultivating it with profit in this quarter of the world, which is less rich in the diversity of its species. In forming plantations, more care than has hitherto been taken, should be paid to the choice of the ground, which should beconstantly moist, urexposed to annual inundations : in such situations its vegetation would be suprisingly beautiful and rapid.

\section{PLATE XL.}

A branch, with leaves of the natural size. Fig. I, Barren flowers. Fig. 2, Fertile flowers. Fig. 3, $A$ seed of the natural size. 



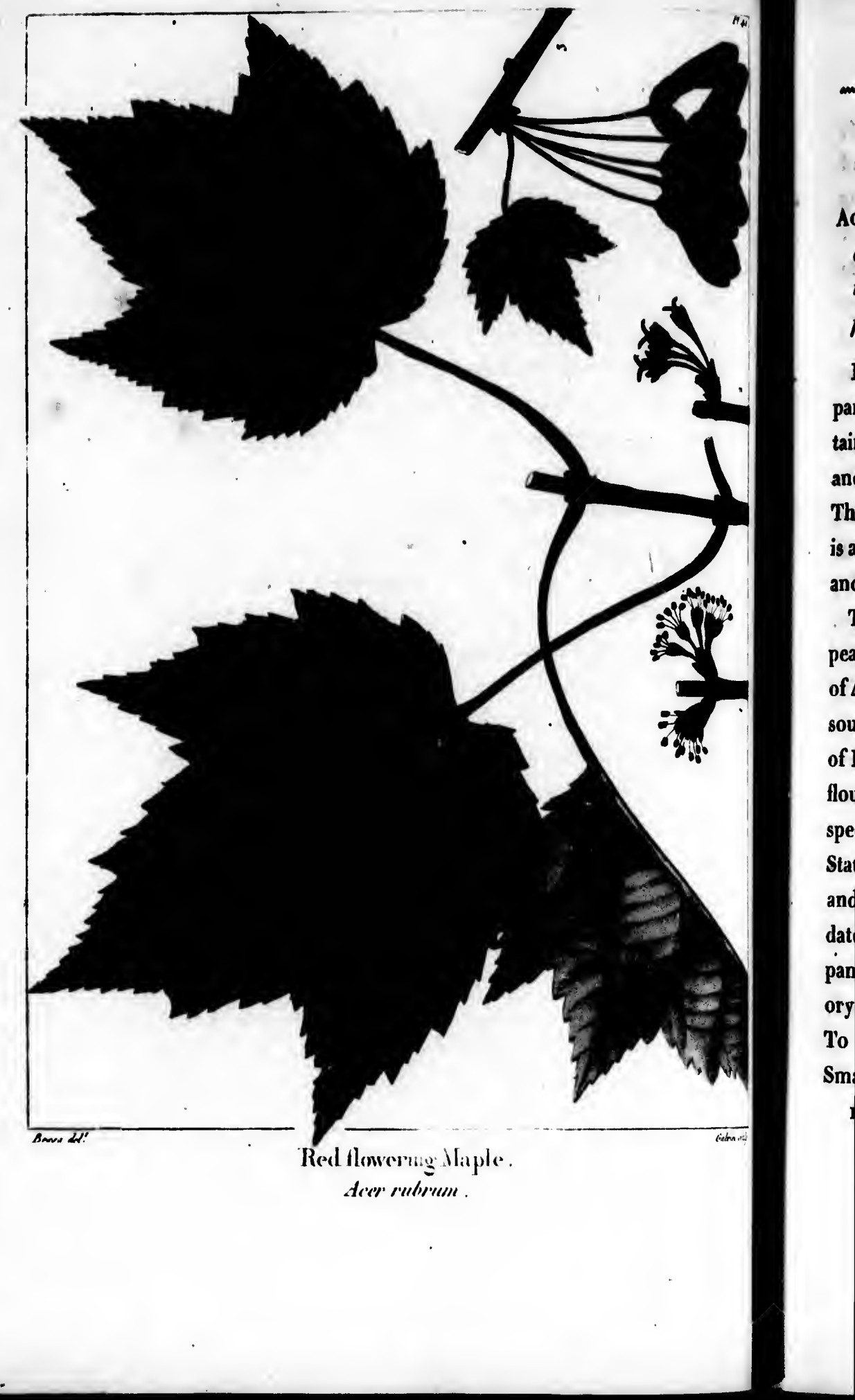




\section{RED FLOWERING MAPLE.}

Aczn RUBRUM. A. folius oppositis, trilobis, inaequaliter dentatis, subtus glaucis : floribus rubris, aggregatis ; germine glaberrimo; umbellis sessilibus : capsulis rubris, pedunculatis.

Dimenest names are given to this tree in different parts of the United States : east of the Alleghany mountains it is called Red flowering Maple, Swamp Maple and Soft Maple ; in the Western Country, simply Maple. The first denomination, which is most generally in use; is also most appropriate, as the young shoots, the flowers, and the fruit are red.

Toward the north, the Red flowering Maple, appears first about Malebaye, in Canada, in the latitude of $48^{\circ}$; but it soon become more common in proceeding southward, and is found abundant to the extremities of Florida and Lower Louisiana. Of all the trees which flourish in wet grounds occasionnally overflowed, this species is most miltiplied in the Middle and Southern States. It occupies, ir: great part, the borders of the creeks, and abounds in all the swamps which are often inundated, and always miry. In these situations, it is accompanied by the Blackgum, Sweetgum, Shellbark Hickory, Swamp White Oak, Black Ash and White Ash. To these are added in the Carolinas and Georgia, the Small Magnolia or Swamp Bay, the Water Oak, Lob-

I. 28 
lolly Bay, Tupelo, and Red Bay. It is a remarkable fact, that west of the mountains, between Brownsville and Pittsburgh, the Red flowering Maple is seen growing on elevated ground with the Oaks and the Walnuts. I have nowhere observed it of as ample dimensions as in Pennsylvania andNew Jersey : in these States exist extensive marshes, called Maple swamps, exclusively covered with it, where it is tound 70 feet high and 3 or 4 feet in diameter.

The Red flowering Meple is the earliest tree whose bloom announces the return of spring ; it is in flower near New York from the 10 to the 15 of April. The blossoms of a beautiful purple or deep red, unfold gore than a fornight before the leaves. They are sessile, aggregate, and situated at the extremity of the branches. The fruit is suspended by long flexible peduncles and is of the same hue with the flowers, though it varies in size and in the intensity of its colouring, according to the exposure and dampness of the soil. The leaves are smaller than those of the preceding species, but in some respects, they resemble them. They are glaucous or whitish underneath, and are palmated or divided into 3 or 4 acuminate lobes, irregularly toothed. The extremities of this tree, which are formed by numerous twigs united at the base, have a remarkable appearance when garnished with flowers and seeds of a deep red, before vegetation has begun generally to revive.

Before the Red flowering Maple exceeds 25 or 30 
feet in beight and 7 or 8 inches in diameter, its bark is perfiectly omonth, and marked with white blotches, by which it is easily diatinguiahable. Afterwards, the trunk, like that of the White Oak and Sweet Gum, becomes brown ; and chapped. In this tree, as in others which grow in wet places, the sap bears a large pruportion to the heart; if indeed the name of heart can properly be given to the irregular star which occupies the center, of large trunks, with points, from 1 to 3 inches in length, projecting into the sap.

The wood of the Red flowering Maple is applicable to interesting uses. It is harder than that of the White Maple, and of a finer and closer grain : hence it is easily wrought in the lathe, and acquires by polishing a glows and silken surface. It is sufficiently solid, and for many purposes it is preferred by workmen to other kinds of wood. It is principally employed for the lower part of Windsor chairs : the pieces are turned in the country, and so considerable is the demand, that boats laden with them arrive at New York and Philadelphia, where an extensive manufacture is carried on, for the consumption of theneighbouring towns, and for exporta tion to the Southern States and to theWest India Islands. The whole frame of japanned chairs is of this wood. except the back, for which Hickory is chosen on account of its superior strength and elasticity. The frame, the nave, and the spokes of spinning wheels are made of it : at Philadelphia it. is exclusively employed for sad- 
dle trees, and in the country it is preferred for yokes, and also for shovels and wooden dishes, which are brought to market, and purchased by the dealers in wooden ware.

It sometimes happens that in very old trees, the grain instead of following a perpendicular direction, is undulated, and this variety bears the name of Curled Maple. This singular arrangement, of which $1 \mathrm{am}$ able to assign no cause, is never witnessed in young trees, nor in the branches of such as exhibit it in the trunk : it is also less conspicious at the center, than near the circumference. Trees offering this disposition are rare, and do not exist in the proportion of one to a hundred. The oerpentine direction of the fibre, which renders them difficult to split and to work, produces in the hands of a skilful mechanic, the most beautiful effects of light and shade. 'These effects are rendered more striking, if, after smoothing the surface of the wood with a double ironed plane, it is rubbed with a little sulphuric acid, and afterwards anointed with linseed oil. On examining it attentively, the varying shades are found to be owing entirely to the inflexion of the rays of light ; which is more sensibly perceived in viewing it in different directions by candle light.

Before Mahogany became generally fashionable in the United States, the most beautiful furniture was of Red flowering Maple, and bedsteads are still made of it, which,in richness and lustre, exceed the finest Mahogany. 
or jokes, and are brought in wooden

ses, the grain on, is unduurled Maple. able to assign , nor in the ik : it is also the circumrare, and do cundred. The renders them in the hands effects of light e striking, if, with a double alphuric acid, On examining 0 be owing enwhich is more ent directions

hionable in the re was of Red Il- made of it, est Mahogany.
At Boston come cabinets makers saw it into thin plates for Iolaying Mahogany. Bnt the most constant was of the Curled Maple is for the stocks of fowling pieces and rilles, which to elegance and lightness unite alidity resulting from the accidental direction of the Gbre.

The cellular integument of the Red flowering Maple is of a duoky red. By boiling, it yields a purplish colour, which, on the addition of sulphate of iron, becomes dark blue approaching to black. It is used in the country, with a cortain portion of Alum in solution, for dying black.

The wood of the Red flowering Maple does not burn well, and is so little esteemed for fuel that it is rarely brought into the cities.

The French Canadians make sugar trom the sap of this Maple, which they call Plaine, but, as in the precediug species, the product of a given measure is only. half as great as is obtained from the Sugar Maple.

It should be observed that the Red flowering Maple never allains its full dimensions except in swamps where the bottom is composed of fertile soil. When the population of the country become denser, these tracts will be cleared and improved by some mode of culture more prolitable than the growth of woods, and especially of this species, which is fit neither for the uses of the whedwright nor for any other solid work; for it possesses litlle strength, is liable to injury from worms, 
and ferments and speedily decays when exposed to the alternations of dryness and moisture. Though at present it is extensively used, its importance in the arts is not such as to entitle it to preservation, andit will doubtless, one day become rare. When the period arrives that it is necessary in the United States as in Europe, to renew the forests or to keep on foot those which have escaped destruction; the American Woodman will find among the Oaks, the Walnuts, and the Ashes, many species more deserving of his care. The Sugar Maple also will be prefered, which grows on uplands, and possesses. in as superior degree all the good properties of the other.From these considera tions the Red flowering Maple appears to have no preten. sions to a place in European forests.

\section{PLATE XLI.}

$A$ branch with leaves of the nutural size. Fif. I, Barren fowers. Nif. 2, Fertile flowers. Fig. 3, Seeds of the natural size. 



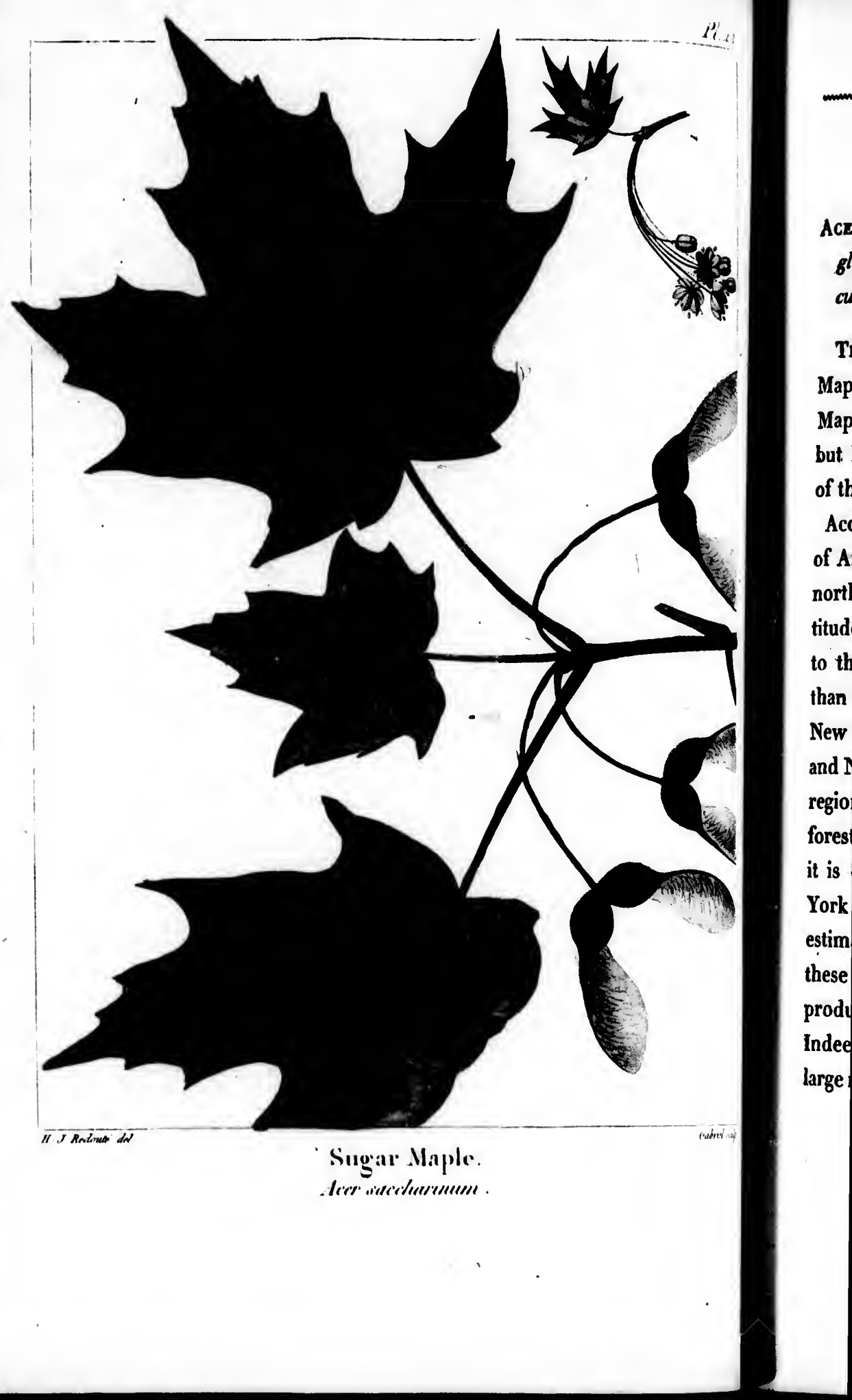




\section{SUGAR MAPLE.}

ACrR SACCBARINUM. A. foliis quinque-partito-palmatis, glabris, margine integris, subtus glaucis : floribius pedunculatis, pendentibus.

Tris species, the most interesting of the American Maples, is called Rock Maple, Hard Maple, and Sugar Maple. The first of these names is most generaly in use, but. I have preserved the last, because it indicates one of the most valuable properties of the tree.

According to my father's researches into the topography of American vegetables, the Sugar Maple begins a little north of Lake St. John, in Canada, near the $48^{\circ}$ of latitude, which, in the rigour of its winter, corresponds to the $68^{\circ}$ in Europe. It is nowhere more abundant than between the $46^{\circ}$ and $4^{\circ}$, which comprise Canada, New Brunswick, Nova Scotia, the States of Vermont and New Hampshire, and the District of Maine : in these regions, it enters largely into the composition of the forests with which they are still covered. Farther south; it is common only in Genessee in the State of New York, and in the Upper parts of Pennsylvania. It is estimated by $D^{*}$ Rush, that in the northern parts of these two States, there are ten millions of acres which produce these trees in the proportion of 30 to an acre Indeed I have noticed, in traversing these districts, large masses of woods formed of them almost exclusively. 
In Genessee, however, a great part of the Maples belong to a species which I shall describe, which has hitherto been confounded by Botanists with the Sugar Maple.

In thelowers parts of Virginia , of the Carolinas, and of Georgi, nd likewise in the Mississipi Territory, this tree is unknown or very rare. It is rapidly disappearing from the forests about New York and Philadelphia, where it is no longer drained for sugar, but is felled for fuel and for other purposes.

Between the parallels mentioned as bounding the tracts where this tree is most abundant, the forests do not resemble those of a more southern latitude : they are composed of two different descriptions of trees divided into two great classes, which alternately occupy the soil and which exist in nearly equal proportions. The first class comprises the resinous trees such as Pines and Spruces, and covers the low grounds and the bottoms of the vallies; these forests are called Black wood lands. The second class consist of leafy trees, such as the Sugar Maple, the White and the Red Beech, the Birches and the Ashes; of which the Sugar Maple is most multiplied. They grow on level grounds or on gentle declivities, and form what are denominated Hand wood lands. In proceeding from the $46^{\circ}$ of latitude northward, the trees of the second class are observed to become more rare, and the resinous trces in the same proportion more abundant : below $4^{\circ}$, on the other hand, the resinous trees are found less common, and the

$c^{\text {th }}$

bec Wa 
iples belong aas hitherto r Maple. linas, and of ory, this tree searing from ia, where it for tuel and

ling the tracts orests do not itude : they ions of trees nately occupy proportions. such as Pines and the boted Black wood rees, such as Red Beech, Sugar Maple is rounds or on denominated $46^{\circ}$ of latitude a are observed ces in the same on the other amon, and the $c^{\text {thers }}$ loose their predorninance in the forests, as they become mingled with the numerous species of Oaks and Walnuts.

The Sugar Maple covers a greater extent of the American soil than any other species of this genus, It flourishes most in mountainous places, where the soil though' fertile is cold and humid. Besides the parts which I have particularly mentioned, where the face of the country is generally of this nature, it is found along the whole chain of the Alleghanies to their termination in Georgia, and on the steep and shady banks of the rivers which rise in these mountains.

The Sugar Maple reaches the height of 70 or 80 feet with a proportional diameter ; but it does not commonly exceed 50 or 60 feet with a diameter of 12 or 18 inches. Well grown, thriving trees are beautiful in their appearance, and easily distinguishable by the whiteness of their bark. The leaves are about 5 inches broad, but they vary in length according to the age and vigour of the tree. They are opposite, attached by long petioles, palmated or unequally divided into five lobes, entire at the edges, of a bright green above, and glaucous or whitish underneath. In autumn, they turn reddish with the first frosts. Except in the colour of the lower surface they nearly resemble the leaves of the Norway Maple. The flowers are small, yellowish, and suspended by slender, drooping peduncles. The seed is contained in two capsules united at base and termina-

I. 
ted in a membraneous wing. It is ripe near New York in the beginning of October, though the capsules attain their full size six weeks earlier. Externally they appear equally perfect, but I have constantly found one of them empty. The fruit is matured only once in two or three years.

The wood when cut is white, but after being wrought and exposed for some time to the light, it takes a rosy tinge. Its grain is fine and close, and when polished, it has a silky lustre. It is very strong and sufficiently heavy, but wants the property of durability, for which the Chesnut and the Oak are so highly esteemed. When exposed to moisture it soon decays, and for this reason it is neglected in civil and naval architecture. In Vermont, New Hampshire, the District of Maine and farther north, where the Oak is not plentiful, this timber is substituted for it, in preference to the Beech, the Birch, and the Elm. When perfectly seasoned, which requires two or three years, it is used by Wheelwrights for axle-trees and spokes, and for lining the runners of common sleds. It is also employed as well as the Red flowering Maple in the manufacture of Windsor chairs. In the country where the houses are wholly of wood, Sugar Maple timber is admitted into the frame; and in the District of Maine, it is preferred to the Beech for the keels of vessels, as it furnishes longer pieces: with the Beech and the Yellow Pine it forms also the lower frams, which is always in the water. 
This wood exhibits two accidental forms in the arrangement of the fibre, of which cabinet-makers take advantage for making beautiful articles of furniture. The first consists in undulations like those of theCurled Maple, the second, which take places only in old trizes that are still sound, and which appears to arise from an inflexion of the fibre from the circumference toward the center, produces spots of half a line in diameter, sometimes contiguous, and sometimes several lines apart. The more numerous the spots, the more beautiful and the more esteemed is the wood : this variety is called Bird's eye Maple. Like the Curled Maple it is used for inlaying Mahogany. Bedsteads are made of it and portable writing desks, which are elegant and highly prized. To obtain the finest effect, the log should be sawn in a direction as nearly as possible parallell to the concentrical circles.

When cutat the proper season the Sugar Maple forms excellent fuel. It is exported from District of Maine for the consumption of Boston, and is equally esteemed with the Hickory. The opinion entertained of it in this respect, in the North of America, accords with the interesting experiments of $\mathbf{M}^{\mathbf{x}}$ Hartig on the comparative heat atforded by different species of European wood, from which it results, that the Sycamore,Acer pseudo-platanus; is superior to every other.

The ashes of the Sugar Maple are rich in the alkaline principle, and it may be confidently asserted, that 
theyfurnish four fifths of the potash exported to Europe from Boston and New York.

In the forges of Vermont and the District of Maine, the charcoal of this wood is preferred to any other, and it is said to be one fifth heavier than the coal made from the same species in the Middle and Southern States ; a fact which sufficiently evinces that this Maple acquires its characteristic properties in perfection, only in northern climates.

The wood of the Sugar Maple is easily distinguished from that of the Ked flowering Maple, which it resembles in appearance, by its weight and hardness. 'There is, besides , a very simple and certain test : a few drops of sulphate of iron being poured on samples of the different species, the Sugar Maple turns greenish, and the White Maple and Red flowering Maple change to a deep blue.

The extraction of sugar from the Maple is a valuable resource in a country, where all classes of society daily make use of tea and coffee.

The process by which it is obtained is very simple, and is every where nearly the same. Though not essentially defective, it might be rendered more perfect and more profitable, by adopting hints which have been thrown out in American publications.

The work is commonly taken in hand in the month of February, or in the beginning of March, while the

cold

with

two $r$ a cen whic a sug and $t$ auger receiv long, a part and $c$ gallon reduc cakes princi

The direct holes the av the $w$ flow 0 mend tree

The in the Oak, very 
cold continues intense, and the ground is still covered with snow. The sap begins to be in motion at this season, two months before the general revival of vegetation. In a central situation, lying convenient to the trees from which the sap is drawn, a shed is constructed, called a sugar camp, which is destined to shelter the boilers and the persons who tend them, from the weather. An auger $3 / 4$ of an inch in diameter, small troughs to receive the sap, tubes of Elder or Sumac, 8 or ro inches long, corresponding in size to the auger, and laid open for a part of their length, buckets for emptying the troughs and conveying the sap to the camp, boilers of 15 or 18 gallons' capacity, moulds to receive the sirop when reduced to a proper consistency for being formed into cakes, and lastly, axes to cut and split the fuel, are the principal ustensils employed in the operation.

The trees are perforated in an obliquely ascending direction, 18 or 20 inches from the fround, with two holes 4 or 5 inches apart. Care should be taken that the augers do not enter more than half an inch within the wood, as experience has shewn the most abundant flow of sap to take place at this depth. It is also recommended to insert the tubes on the south side of the tree; but this useful hint is not always attended to.

The troughs, which contain 2 or 3 gallons, are made in the Northern States, of White Pine, of White or Black Oak, or of Maple ; on the Ohio, the Mulberry, which is very abundant, is preferred. The Chesnut, the Black 
Walnut, and the Butternut should be rejected, as they impart to the liquid the colouring matter and bitter principle, with which they are impregnated.

$A$ trough is placed on the ground at the foot of each tree, and the sap is every day collected and temporarily poured into casks, from which it is drawn out to fill the boilers. The evaporation is kept up by a brisk fire, and the skum is carefully taken off during this part of the process. Fresh sap is added from time to time, and the heat is maintained till the liquid is reduced to a sirop, after which it is left to cool, and then strained through a blanket or other woolen stuff, to separate the remaining impurities.

Some persons recommend leaving the sirop twelve hours, before boiling it for the last time ; others proceed with it immediately. In either case, the boilers are only. half filled, and by an active, steady heat, the liquor is rapidly riduced to the proper consistency for being poured into the moulds. The evaporaration is known to have proceeded far enough, when, upon rubbing a drop of the sirop between the fingers, it is perceived to be granular. If it is in danger of boiling over, a bit of lard or of butter, is thrown into it, which instantly calms the ebullition. 'The molasses being drained off from the moulds, the sugar is no longer deliquescent, like the raw sugar of the West Indies.

Maple Sugar manufactured in this way, is lighter coloured, in proportion to the care with which it is made

and the

It is sup to such is as $p$ When sumed the dis country used in

The it becor ter, and this cuse is super days ex vinegar

In a $\mathrm{P}$ al years Sugar I pour I leaven the esse is thus

The describe from $w$ The o from di 
sUGan mapLE.

ond the judgment with which the evaporation is conducted. It is superior to the brown Sugar of the Colonies, at least; to such as is generally used in the United States : its taste is as pleasant, and it is as good for culinary purposes. When refined, it equals in beauty the finest Sugar consumed in Europe. It is made use of, however, only in the districts where it is made, and there, only in the country : from prejudice or taste, imported sugar is used in all the small towns, and in the inns.

The sap continues to flow for six weeks; after which; it becomes less abundant, less rich in saccharine matter, and sommetimes even incapable of chrystalisation. In this cuse, it is consumed in the state of molasses, which is superior to that of the Islands. After three or four days exposure to the sun, Maple sap is converted into vinegar, by the acetous fermention.

In a periodical work , published at Philadelphia several years since, the following receipt is given for making Sugar Maple becr: Upon 4 gallons of boiling water, pour I quart of Maple molasses; add a little yeast or leaven to excite the fermentation, and a spoonful of the essence of spruce : a very pleasant and salutary drink is thus obtained.

The process for extracting the sugar which I have described is the most common one, and it is the same from whatever species of Maple the sugar is made.

The omount of sugar manufactured in a year varies from different causes. $\Lambda$ cold and dry winter renders the. 
trees more productive than a changeable and humid ceason. It is observed, that when a frosty night is followed by a dry and brilliant day, the sap flows abundantly; and 2 or 3 gallone are sometimes yielded by a single tree, in twenty four hours. Three persons are found sufficient to tend 250 trees, which give 1000 pounds of sugar, or 4 pounds from each tree. But this product is not uniform, for many farmers on the Ohio have assured me, that they did not commonly obtain more than 2 pounds from a tree.

Trees which grow in low and moist places afford a greater quantity of sap than those which occupy rising grounds, but it is less rich in the saccharine principle. That of insulated trees, left standing in the middle of fields or by the side of fences, is the best. It is also remarked, that in districts which have been cleared of other trees, and even of the less vigorous Sugar Maples, the product of the remainder is, proportionally, most considerable.

While I resided in Pittsburgh, the following curious particulars appeared in the Greensburgh Gazette : " Having introduced " says the writer, " twenty tubes into a Sugar Maple, I drew from it the same day, 23 gallons and 3 quarts of sap, which gave 7 pounds and a quarter of sugar : 33 pounds have been made this season firom the same tree ; which supposes 100 gallons of sap." It appears here, that only a little more than 3 gallons, was required for a pound, though four are commonly allowed.

In th in one to the ployed. escapes have be ed to th the mor one day the banl cutting f year. I green co beneath. but this that the sage to $t$ that tred diminut three fe and the succensir nearly forated.

In the quantitic Vermon Genesec

J. 
In the foregoing experiments, 5 quarts were drawn in one day from each tube, which is about equal to in the quantity discharged, when two pipes are employed, Might it not hence be concluded, that the sap escapes only from the orilices of the vessels, which have been divlded by the auger, without being diverted to this lasue, from the neighbouring parts? I am the more inclined to this opinion, as in rambling one day, in the profound solitude of the forests, on the banks of the Ohio, the idea suggested itself to me of cutting into a Maple which had been bored the preceding year. I lound amid the white mass of its wood, a green column, equal in width and in depth to the hole beneath. The organisation appeared not to be affected; but this is not suflicient to warrant the conclusion, that these veusels would be in condition to give passage to the sap, the sncceeding year. It may be objected, that trees have been drained for 30 years, without diminution of their produce. But a tree of two or three feet in diameter, presents an extensive surface, and the tubes are every year shifted : besides, the succensive layers of 30 or 40 years, would restore it nearly to the state of one that never had been perforated.

In the United States, Maple sugar is made in greatest quantities, it the upper part of New Hampshire, in Vermont, in the Slate of New York, particularly in Genesec, and in the Counties of Pennsylvania which 
lie on the eastern and western branches of the Susquehannah ; west of the mountains, in the country bordering on the Alleghany, Mononghahela, and Ohio rivers. The farmers, after laying aside a sufticient store for their own consumption, sell the residue to the shopkeepers in the small towns of the neighbourhood, at 8 cents a pound, by whom it is retailed at $I \mathrm{I}$ cents. A great deal of sugar is also made, in Upper Canada, and on the Wabash near Michillimackinac. The Indians dispose of it to the commissioners of the North Western Company established at Montreal, for the use of the numerous agents who go out in their employ, in quest of furs, beyond Lake Superior. In Nova Scotia and the District of Maine, and on the highest mountains of Virginia and the Carolinas, where these trees are sufficiently common, the manufacture is less considerable, and probably six sevenths of the inhabitants consume imported sugar.

It has been advanced, and doubtless correctly', that the northern parts of New York and Pennsylvania contain Maples enough to supply the whole consumption of the United States. But the annual produce by no means answers to this patriotic calculation. 'The trees grow

- The annual consumption of sugar in the United States is about 80 millions of pounds; of which more than 50 millions of pounds are imported; more than 10 millions produced by the cane in Louisiana ; aud, probably, as much as 10 millions made from the Sugar Maple. 
Susquey bordeio rivers. store for he shopnood, at cents. A uada, and dians disWestern ase of the ploy, in Scotia and nountains trees are $s$ considenhabitants

ectly', that vania connsumption yo means trees grow

States is about ons of pounds cane in Louirorn the Sugar

upon excellent lands, which by the influx of emigrants from the older settlements, and by the surprising increase of the population already established, are rapidly clearing; so that in less, perhaps, than half a century, the Maples will be confined to exposures too steep for cultivation, and will afford no resource, except to the proprietor on whose domain they $g_{k} \in w$. At this period also, the wood will probably produce a greater and more ready profit than the sugar. It has been proposed to plant Sugar Maples in orchards or about the lields : but would it not be more certainly alvanlageous to multiply the Apple tree, which grows in soils too dry to sustain the vegetation of the Maple? All that has been said on this. subject, must be considered as speculative merely, since, in the Eastern States, where information is generally diffused, no enterprises of this nature have been undertaken, by which the importation of sugar might be diminished.

Wild and domestic animals are inordinately fond of Maple juice, and break throngh their enclosures to sate themselves with it.

The details into which I bave entered, concerning the Sugar Maple, furnish the means of estimating its importance, with reference both to its sap, and to its wood. I have indicated the regions where it grows, and the soil in.which it thrives; and 1 feel authorised in seriously recommending it for propagation in the North of Europe. Its sap and its wood are superior to 
those of the Norway Maple and of the Sycamore, and in the same countries where these two species abound in the forests, its success would be most complete, and its cultivation most profitable.

\section{PLATE XLII.}

A branch with leaves and seeds of the natural size. Fig. 1, A small twig with flowers. 



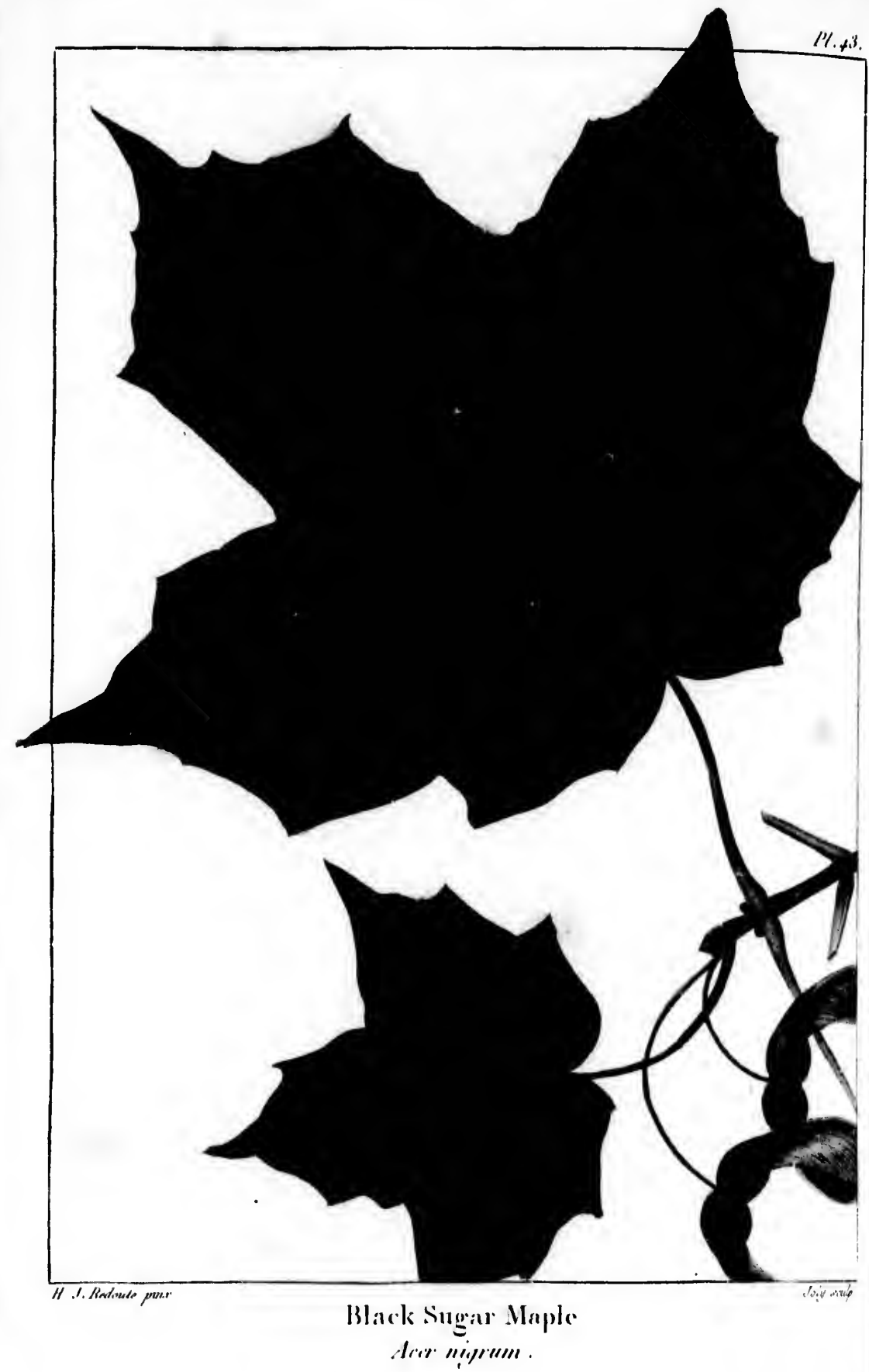

мекики

ACER

ap

vin

bos

IN

vania

and

the $\mathbf{n}$

chara

bably

comp

somet

Genes

Maple

arisen

emigr

Black

other

the sa

ed by tions

To

Tree

river 


\section{BLACK SUGAR TREE.}

ACER NIGRUM. A. foliis quinque-partito-palmatis, sinubus apertis, margine integra, subtìs pubescentibus, atroviridibus : floribus corymbis : capsulis turgidè subglobosis.

IN the Western States, and in the parts of Pennsylvania and Virginia, which lie between the mountains and the Ohio, this species of Maple is designated by the name of Sugar Tree, and frequently, by the more characteristic denomination of Black Sugar Tree ; probably, on account of the dark colour of its leaves, in comparison with those of the true Sugar Maple, which sometimes grows with it. In the extensive country of Genesee both species are indiscriminately called Rock Maple and Sugar Maple. This confusion seems to have arisen trom the country's being settled principally by emigrants from the Eastern States, who, finding the Black Sugar Tree applicable to the same uses with the other, and equally productive of sugar, have given it the same name.The two species have also been confounded by Botanists, in describing the vegetable productions of America.

Towards the north, I first observed the Black Sugar Tree, near Windsor in Vermont, on the Connecticut river. But from its inferior size, and its scarceness, it 
may be inferred that it belongs to a more southern climate. Accordingly, a few degrees lower, it forms a large part of the forests of Genesee, and covers the inmense vallies, through which flow the great rivers of the West. In these bottoms* it is one of the most common and one of the loftiest trees.

The leaves are 4 or 5 inches long, and exibit, in every respect, nearly the same confirmation as those of the true Sugar Maple. They differ from them, principally, in being of a deeper green and of a thicker texture, and in having more open sinuses : they are also slightly downy, which is most sensibly perceptible on the main rib.

The flowers, like those of the Sugar Maple, are suspended by long, flexible peduncles: the seeds, also, are similar, and are ripe about the same time, that is, about the in of October.

The wood is much like that of the other species, but it is coarser-grained, and less brilliant when polished. It is little used, because, wherever it abounds, other trees are found, such as the $0 \mathrm{k}$, the Walnut, the Cherry tree, and the Mulberry, which are more esteemed for building and for cabinet making. It is, however, preferred for the trames of Windsor chairs, and is considered after the Hickories as the best fuel. Its

* This word has become authorised by general use in the United States. 
BLACR SUGAR TREE.

most important use is for making Sugar, of which it annually yields a vast amount, in the neighbourhood of Pittsburgh.

When the Black Sugar'Tree stands alone, it naturally assumes a regular and agreeable shape. Its foliage, of a darker tint and more tufted than that of the other Maples, renders it proper for torming avenues, and for adorning parks and gardens; in fine, for every situation where thick shade is desired, as a shelter from the sun.

\section{PLATE XLIII.}

$A$ branch with a leaf and seeds of the natural size.

are susis, also, , that is, ecies, but polished. ds, other lnut, the esteemis, howehairs, and t fuel. Its 
240.

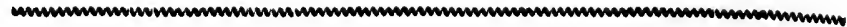

\section{NORWAY MAPLE.}

Acer platanoides. A. foliis quinque-lobis, acuminatis, utrinque glabris, lobis dentatis : corymbosis erectis, pedunculis glabris.

Tris species of Maple is found in the same parts of Europe with the Sycamore, but it is. most multiplied in Sweden and Norway; whence it has received the name of Norway Maple.

Like the Sycamore it attains a lofty height and a diameter of several feet, and ranks among the largest trees of the north of Europe. Its leaves are broad, of a fine texture, and of a light green colour; in shape, they resemble those of the Black Sugar tree and the Sugar Maple. They are not whitish underneath like those of the Sugar Maple, and when the petiole is broken a milky fluid distils from it, which does not take place in the American species:

The flowers of the Norway Maple are small, yellowish and suspended by pretty long peduncles. The seeds grow in two capsules, which are united at the base, compressed, and garnished with large divergent, membraneous wings. They are ripe in the month of September.

In the winter, when the Norway Maple and the Sycamore are stripped of their lcaves, they may still be dis- 


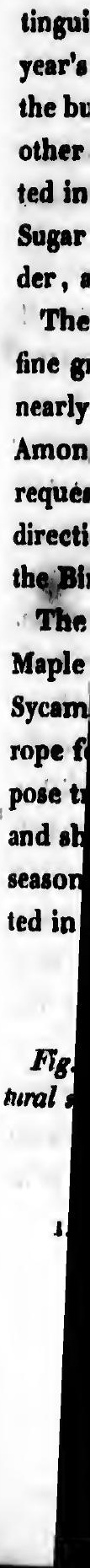


tinguished by their buds. On the Sycamore the last year's shoots are larger than on the Norway $M$ ple, and the buds are of a yellowish colour, while those of the other apecies are of a reddish complexion, and are united in groups of three. On the two species of American Sugar Maple, the choots are still more tapering and slender, and the buds are nearly black.

The wood of the Norway Maple is very white and very fine grained i it is easily wrought, and is employed for nearly the same purposes with that of the Sycamore. Among cabinet-makers in Germany such trees are in requeat as prenent agreeable accidental variations in the direction of the fibre, similar to the Curled Maple and the Bird's Eye Maple:

The rapid and beautiful vegetation of the Norway Maple in soilo inferior to such as are required by the Sycamore, causes it to be extensively planted in $\mathrm{Eu}$ rope for the embellishment of gardens; for which purpose trees are preferred that develop their foliage early, and shed it late, and that afford through the intemperate season a refreshing shade; all which advantages are united in the Norway Maple.

\section{PLATE KLIV.}

Fig. 1. A lnaf of half the natural size. A seed of the natural size.

s. 


\section{SYCAMORE TREE.}

ACEn PsEUd0-pritaxus. A. folits quinqre bobis, incorpa liter dentatis subits glaucescentibus : fonibus subspicatis, pendectis.

Tuss beautiful tree is diffused over all the center of Europe, and abounds especially in Bohemia , Hungary, and Poland. It thrives most luxuriantly in moist and fertile soils, and when expanded to its full dimensions, it is 60 or 70 feet in height, and 2 or 3 feet in diameter. Its head in spacious, and its foliage thick. On old trees, the bark of the trunk is deeply furraned; on such as are lesa than 6 inches in diameter, it is perfectly smooth. The leaves of the Sycamore are oppesite with long petioles, large, and distinctly divided into five unequal lobes ; they are of a dark green above, and whitish underneath. In the heat of midsummer, they are covered with a very sweet, viscid substance; which is gathered with avidity by bees. The flowers appear towards the end of April ; they are small, greenish ; and grouped into pendulous clusters from 3 to 4 inches in length. The seed is in capsules about an freh in length, united at the base, and terminated by a membraneous wing.

When the Sycamore is fully grown, its wood is fine grained and susceptible of a brilliant polish. In those parts of Europe where it is most common, it is in

Sycai temp the Suga on ac of it. affor 
demand wills turners for making-wooden ware. It is used for making violins; and when its grain is undulated, for ornamenting forte-pianos. By the interesting experiments of $\mathbf{M}^{\prime}$. Ilartig, Grand Master of the forests of Prussia, un the comparative value of different species of wood as combustibles, the Sycamore was found to afford more heat than any other wood of the North of Europe.

For several years past, sugar has been made from the Sycamore, in Bohemia and Hungary. Though the attempt has completely succeeded, it appears certain that the sugar in yiclded in a smaller proportion than by the Sugar Maple.

In France and Lngland, the Sycamore is a rare tree in the forests, but it is multiplied in pleasure grounds, on account of its rapid growth, the early developement of its foliage in the spring, and the fine shade which it afforda through the summer.

It has been observed in England that the foliage or this. tree is lew injured than that of others, by the saline 'pours wafted trom the sea; hence it is chosen for situations exposed to these winds. The justness of the observation I have never had an opportunity of examining.

The Sycamore appears to me to possess no one superior proporty, which entitles it to preference in the United Stalo:s, over the Sugar Maple and the Black Sugar Tree; but individuals who wish to possess the species may, I doubt not, obtain seeds, by addressing 
244

SYCAMORE TAEE.

themselves to the politeness of Col. Steevens, who has it at his delightful seat at Hoboken near New York.

\section{PLATE XLIV.}

Ing $2, A$ leaf of half the natural size. A seed of the na. tural sice. 



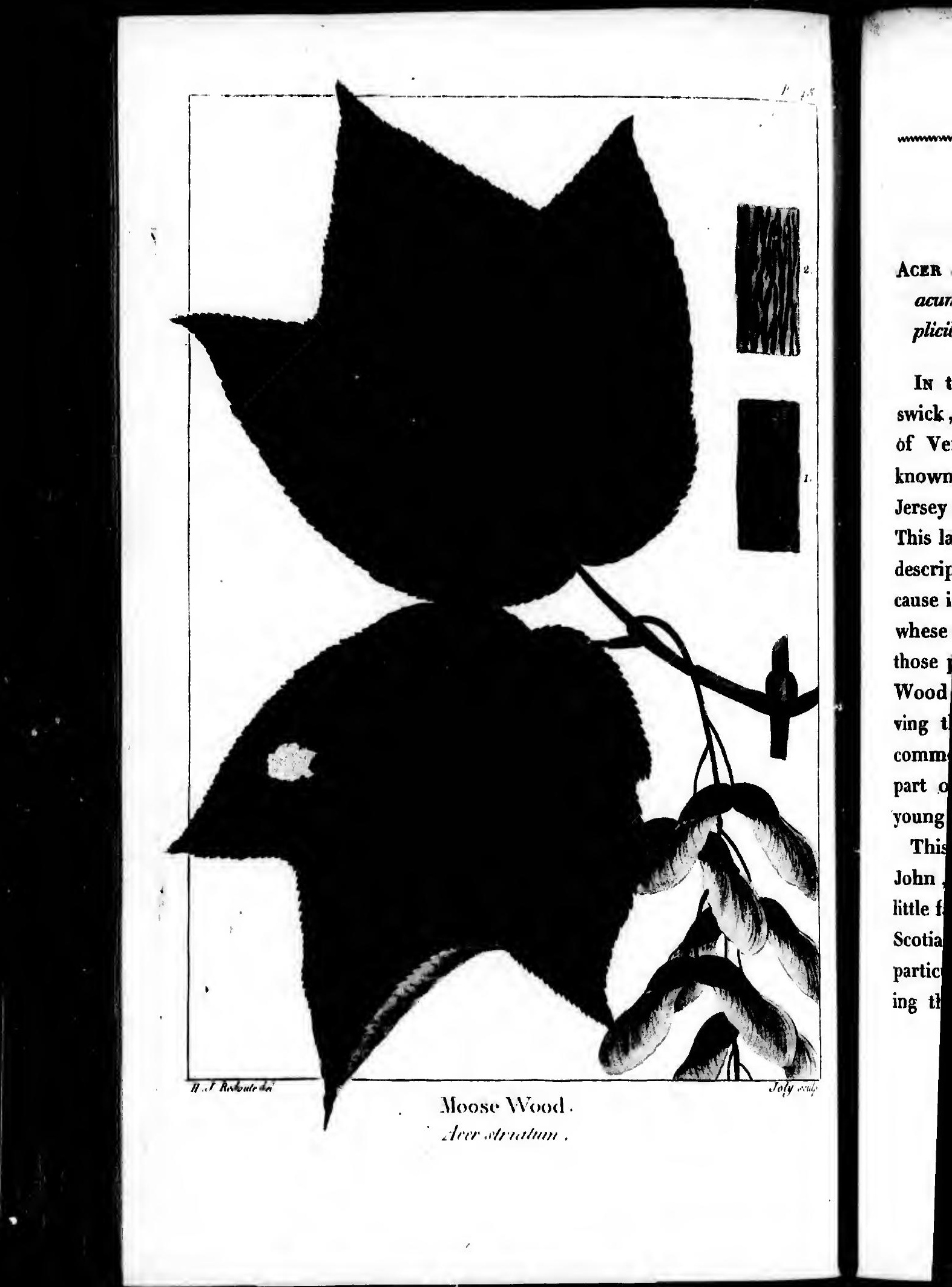




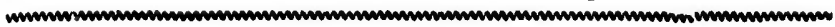

\section{MOOSE WOOD.}

Acen Strintum. A. foliis infernè rotundatis, supernè acuminato-tricuspidibus, argutè serratss : racemis simplicibus, pendentibus.

Is the Provinces of Nova Scotia and New Brunswick, in the District of Maine, and in the States of Vermont and New Hampshire, this Maple is known only by the name of Moose Wood : in New. Jersey and Pennsylvania it is called Striped Maple. This last denomination, which is preferable as being descriptive, I have thought proper to reject, because it is in use only in a part of the United States whese the tree is rare, and is wholly unknown, in those parts in which it abounds. The name of Moose Wood was given it by the first settlers, from observing that the Moose, an animal now become uncommon in this region, subsisted, during the latter part of winter and the beginning of spring upon its young twigs.

This tree makes its first appearance near Lake St. John, in the latitude of about $47^{\circ}$. that is to say, a little farther north than the preceding species. In Nova Scotia and the District of Maine, where I have most particularly observed it, it fills the forests. In approaching the Hudson it becomes more rare, and beyond 
this boundary, it is confined to the mountainous tracts of the Alleghanies, on which it is found, in cold and shaded exposures, along the whole range to its termination in Georgia.

In the District of Maine I have always found the Moose Wood most vigourous in mixt forests, or what are called Mixture lands; where the woods are composed of the Sugar Maple, the Beech, the White Birch, the Yellow Birch, and the Hemlock Spruce. In these forests, it constitutes a great part of the under growth; for its ordinary height is less than ro feet', though I have found individual trees, of more than twice this stature.

The trunk and branches of the Moose Wood are clad in a smooth, green bark, longitudinally marked with black stripes, by which it is easily distinguishable, at all seasons of the year.

This is one of the earliest trees of North America, whose vegetation announces the approach of the genial season. Its buds and leaves, when beginning to unfold, are rose coloured, and have a pleasing effect; but this hue soon changes to green. On luxuriant trees, the leaves are of a pretty thick texture, and finely serrate. They are 4 or 5 inches broad, rounded at the base, and divided into three deep and acute lobes. The flowers are of a greenish cast, and grouped on long, pendulous peduncles. The fruit, which in the main resembles that of the other Maples, is remarkable for a

small c in abur

The in any fine-gr: instead ern a which the inh close of source season begin $t$ turned shoots, resourc the twi similar the $W$

This rope in as one spring sing eff In the opy of change drier 
and the or what compoe Birch, these fogrowth ; though I wice this

Vood are marked uishable,

America , the genial to unfold, $t$; but this trees, the ely serrate. the base, bes. The d on long, e main rekable for a

small cavity on one side of the capsules : it is produced in abundance, and is ripe about the end of September.

The inferior size of the Moose Wood forbids its use in any kind of construction; but as it is white and fine-grained, the cabinet-makers of Halifax, employ it instead of the Holly, which does not grow in so northern a climate, for forming the white lines, with which they inlay Mahngany. Its principal advantage to the inhabitants consists in furnishing them, at the close of winter, when their forage is exhansted, a resource for sustaining their cattle, till the advancing season has renewed the herbage. As sonn as the buds begin to swell; the famished horses and neat cattle are turned loose into the woods', to browse on the young shoots, which they consume with avidity. Poor as this resource may appear, it is not wholly inadequate, since the twigs are tender, and full of saccharine juice. $A$ similar practice prevails, also, in the new settlements of the West.

This species of Maple has been long cultivited in Europe in parks and extensive gardens. It is in request, as one of the earliest trees to feel the approach of spring, but more particularly, on account of the pleasing effect of the white veins, which variegate its trunk. In the primitive forests, where it grows beneath a canopy of impervious shade, these veins are black : the change of colour seems owing to its being planted in drier soils, more open to the sun. Most of the trees 
248

Moose weod.

of this species, which now grow in Europe, have been grafted on the lofty Sycamore, whose vigor is felt by the Moose Wood, and expands it to four times its natural dimensions.

\section{PLATE XLV.}

A branch with fruit of the natural size. Fig. 1, Bark of a tree in the forests of North America. Fig. 2, Bark of a tree cullivated on dry and open ground. 


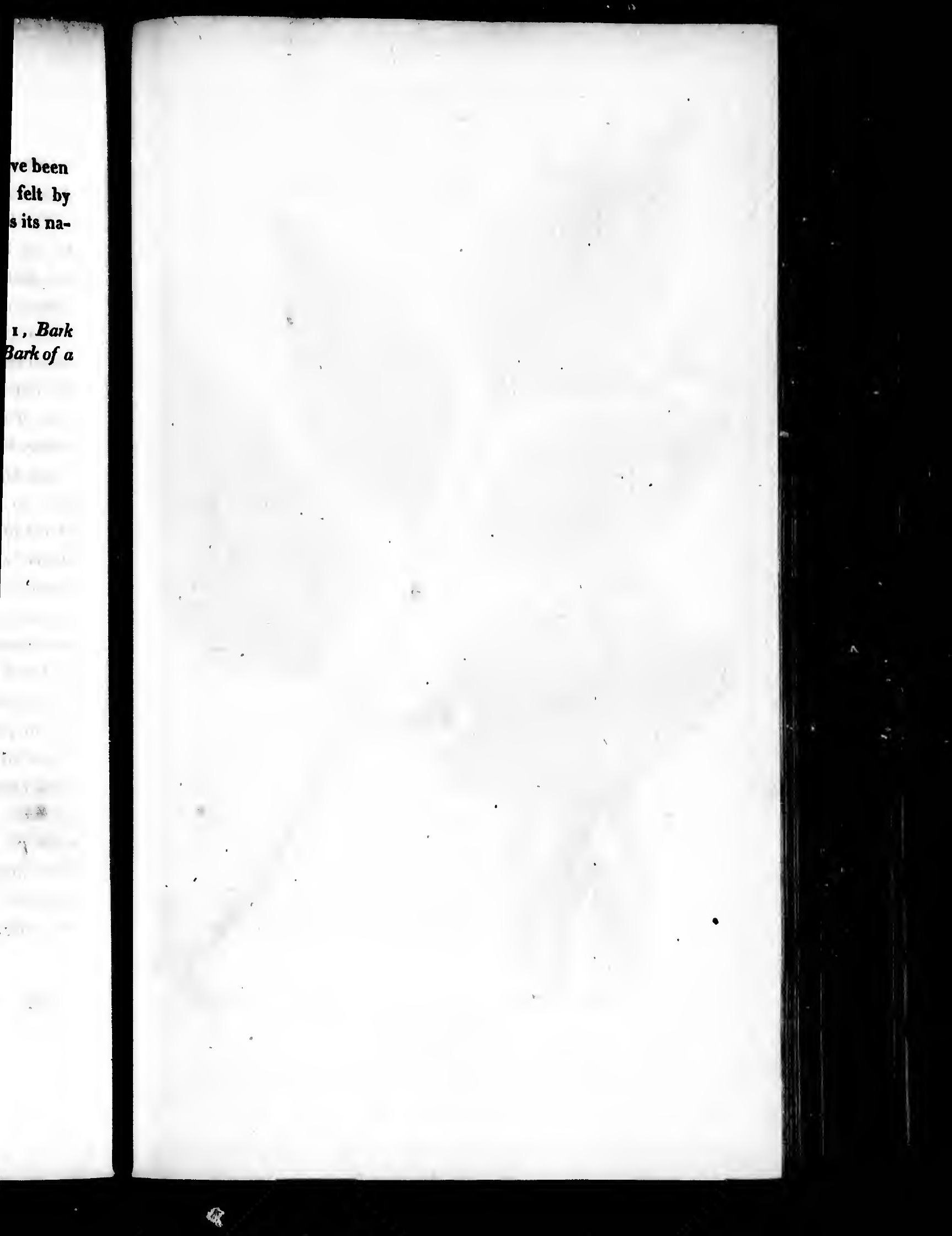




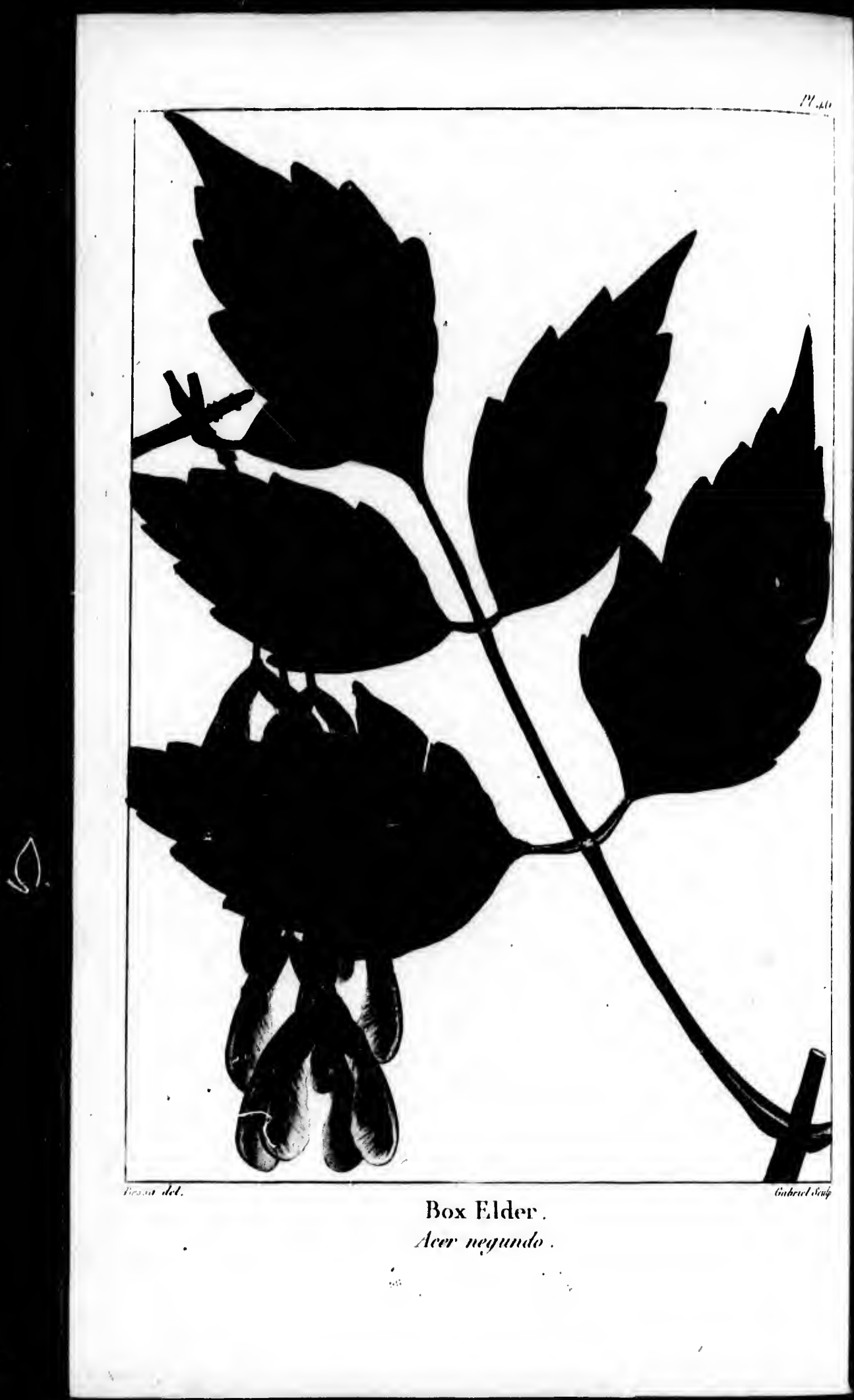

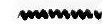

ACER

IN $t$ ] tree is mount tively $\mathrm{c}$ person Maple

I have of any is sanct it Erad The from the tre Each odd of and sh is of : borne pendy of I. 


\section{BOX ELDER}

O n

\section{ASH LEAVED MAPLE.}

ACER NEgUNDo. A. foliis pinnatis ternatisve, inaqualiter serratis : floribus dioicis.

In the Country west of the Alleghanies, where this tree is common, it is called Box Elder; east of the mountains it is more rare, and having been less attentively observed, it has received no specific name. Some persons, however, distinguish it by that of Ash leaved Maple, which is a perfectly appropriate denomination : I have chosen the other, though absolutely insignificant of any characteristic property of the tree, because it is sanctioned by general use. The French of Illinois call it Erable ì Giguières.

The leaves of the Box Elder are opposite, and are from 6 to 15 inches long, according to the vigour of the tree, and the moisture of the soil in which it grows. Each leaf is composed of two pair of leaflets with an odd one. The leaflets are petiolated, oval-acuminate, and sharply toothed : towards fall, the common petiole is of a deep red. The barren and fertile flowers are borne on different trees, and are supported by slender, pendulous peduncles , 6 or 7 inches in length.

Of all the Maples of the United States, this species

I. 
ventures least into northern latitudes, for in the Atlantic States, it is first seen on the banks of the Delaware, in the neigbourhood of Philadelphia, and even there it is rare. In the maritime parts of the Southern States, also, it is far from being a common tree; which is less altributable to the heat of the summer, than to the marshy nature of the soil on the borders of the rivers. West of the mountains, on the contrary, it is extremely multiplied, and instead of being confined, as in the upper parts of Virginia and of the Carolinas, to the river sides, it grows in the woods, with the Locust, Wild Cherry, and CoffeeTree. But in the bottoms which skirt the rivers, where the soil is deep, fertile, constantly moist, and often inundated, this tree is most abundant, and most fully. expanded. Even here, it can be considered only as a tree of secondary size : the largest Box Eliers that I have seen were not more than 50 feet in height, and 20 inches in diameter, and trees of these dimensions are found only in Tennesee and in the back parts of Georgia, which lie far to the south. In Kentucky they are of only half this height. Though growing in thick forests, the Box Elder expands into a bead like that of the Apple tree. I have remarked this form , particularly, on the banks of the Ohio, where I have also observed that the trunk bulges into knots at unequal distances, and is often decayed at the heart. A fine row of Box Elders in the botanical garden of Paris, along the Rue de Buffon, affords a sufticiently just

idea ghah has 1 tree than its tri odouı sap to the $h$ veins. emplo Wild and is when errone this sp Mor duced quents it is in accoun of its $\mathrm{f}$ contra. of a liv is beld its leav The 
Atlantic , in the $t$ is rare. so, it is ibutable sature of e mounlied, and is of Virgrows in d Coffee. 8 , where ind often nost fully. only as a ers that I ight, and e dimenback parts Kentucky rowing in head like orm , parre I have ots at uneeart. A fine of Paris, iently just

idea of their appearance in the forests, on the Mononghahela and Ohio rivers. It may be concluded from what has been said, that to attain its full proportions, this tree requires a climate three or four degrees milder than that of Philadelphia, Pittsburgh, and Paris.

The Box Elder branches at a small height. The bark of its trunk is brown, and I have remarked a disagreeable odour in the cellular integument. The proportion of the sap to the heart is large, except in very old trees : in these the heart is variegated with rose coloured and bluish veins. Some cabinet-makers in the Western Country, employ it to ornament furniture made of Mahogany or Wild Cherry 'Tree. The wood is of a fine and close grain, and is said to split with difficulty : but as it soon decays when exposed to the air, it is little used: It has been erroneously asserted that sugar is made from the sap of this species.

More than 50 years since, the Box Elder was introduced into France by Admiral La Gallissonière. Subsequently, it has spread into Germany and England, where it is in great request for adorning pleasure grounds, on account of the rapidity of its growth, and the beauty ot its foliage, whose bright green forms an agreeable contrast with the surrounding trees. Its young branches, of a lively green, contribute to the favour in which it is held, and serve to distinguish it in the winter, when: itsleaves are fallen.

The utility of its wood, I believe it has, of late, 
252

BOX ELDER OA ASR LEAVEd MAPLE.

been exaggerated; both Europe and America possess many trees superior in strength as well as in size. It appears certain, however, that, growing in copses, and cut every three or four years, it would afford a protitable product in its sprouts, which are very numerous, and

which, during the first years, shoot with astonishing rapidity. The success of this experiment will be more certain, if it is made on grounds unfailingly moist and cool ; though the Box Elder may seem, for a few years, to prosper in dry and meager soils, it sooner or later pines and perishes. Of this I became convinced in convering with several proprietors, in the environs of Paris, who, after some recent publications on this tree, had made an unsuccessful attempt to derive profit from their poor lands, by planting them with the Box Elder.

\section{PLATE XLVI.}

A branch with leaves and seeds of the natural size. 

profitable ous, and tonishing l be more moist and few years, laterpines in converhs of Paris, tree, had rofit from Box Elder.

size. 


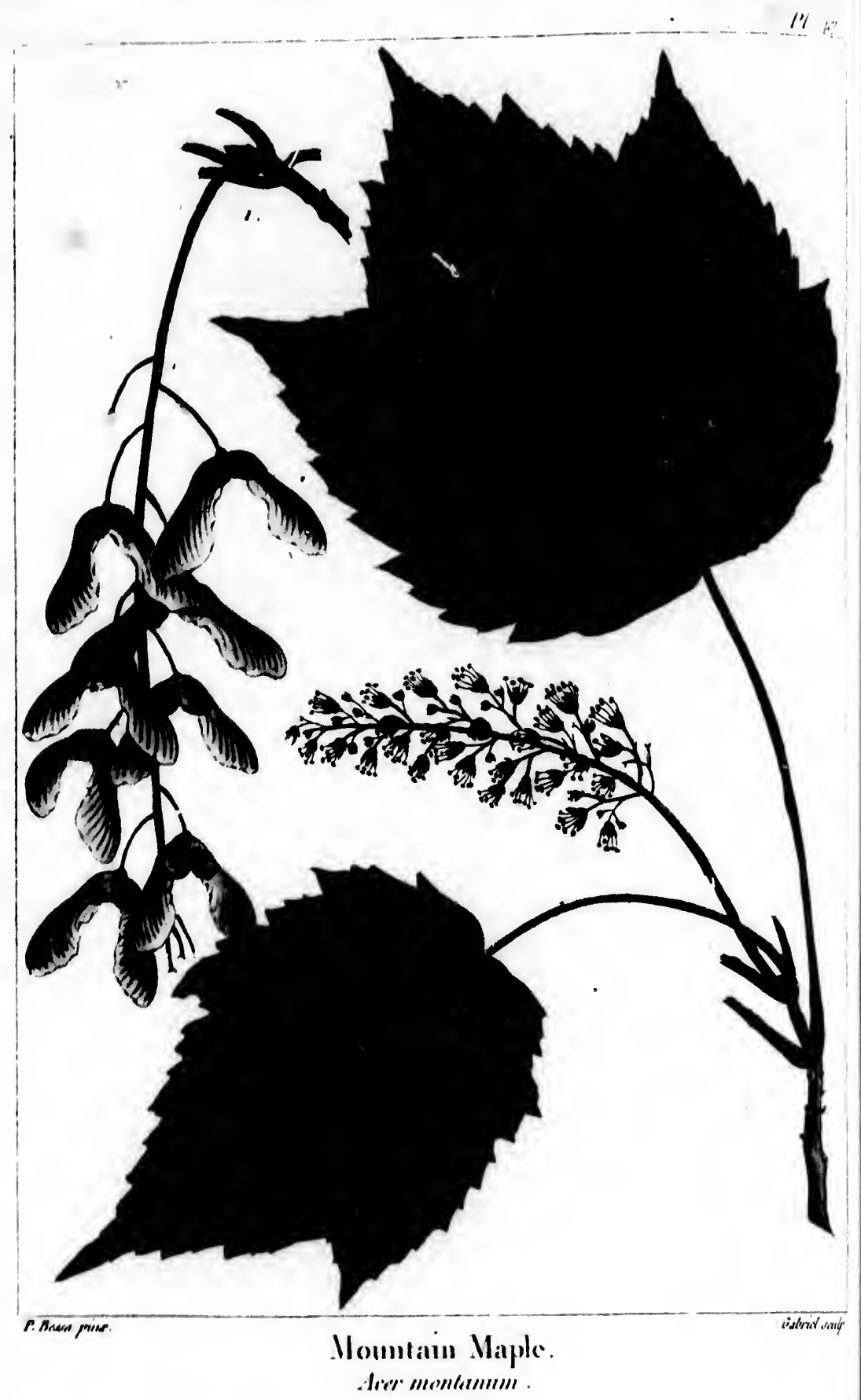




\section{MOUNTAIN MAPLE.}

AGER MONTANUM. A. foliis tri-subquinquelobis, acuminatis, dentatis, rugosis : racemis spiciformibus, suberectis, petalis linearibus.

This species is more abundant in Canada, Nova Scofia, and along the whole range of the Alleghany Mountains than in any other part of North America. It is called Mountain Maple and Low Maple. Though the last of these names indicates the stature of the tree, I have retained the first, which is more generally in use, and which is likewise appropriate, as this Maple grows of preference on the declivities of mountains exposed to the north, and in cool, moist, and shady situations, on the abrupt and rocky banks of torrents and rivers. On the Mohawk, for instance, near the little falls, it abounds among the enormous rocks which lic scattered along its sides.

The Mountain Maple is 6 or 8 foct in height, and it blooms even at a smaller clevation. It most frequently grows in the form of a slirul, with a single and straight stock. The leaves are large, opposite and divided into three acute and indented lobes : they are slightly hairy at their unfolding, and when fully grown, they are uneven and of dark greeu upon the upper surface. The blossoms are small, of a greenish colour, and produced in semi-erect spikes from 2 (1) 4 inches in length. The seeds, which are smaller llian llose of any other Amer 
254

MOUNTAIN MAPLE.

ican Maple, are fixed upon slender, pendulous footstalks : they are reddish at their maturity, and each of them is surmounted by a membraneous wing, and has a small cavity upon one side.

The Mountain Maple is too small to be profitably. cultivated for its wood, and as its flowers, its roots, and its bark are destitute of any very sensible odour, it promises no resources to medecine. It is found in the gardens of the curious, rather to complete the series of species, than for any remarkable property of its foliage or of its flowers.

This species is commonly grafted upon the Sycamore, and like the Moose Wood, it is thus augmented to twice its natural dimensions. This surpriving developement proves how great are the advant * hich may be derived from this process and from waitinued cultivation, in meliorating inferior vegetables.

\section{PLATE XLVII.}

$A$ branch with the leaves and flowers of their natural size Fig. I, A bunch of seeds of the natural size. 



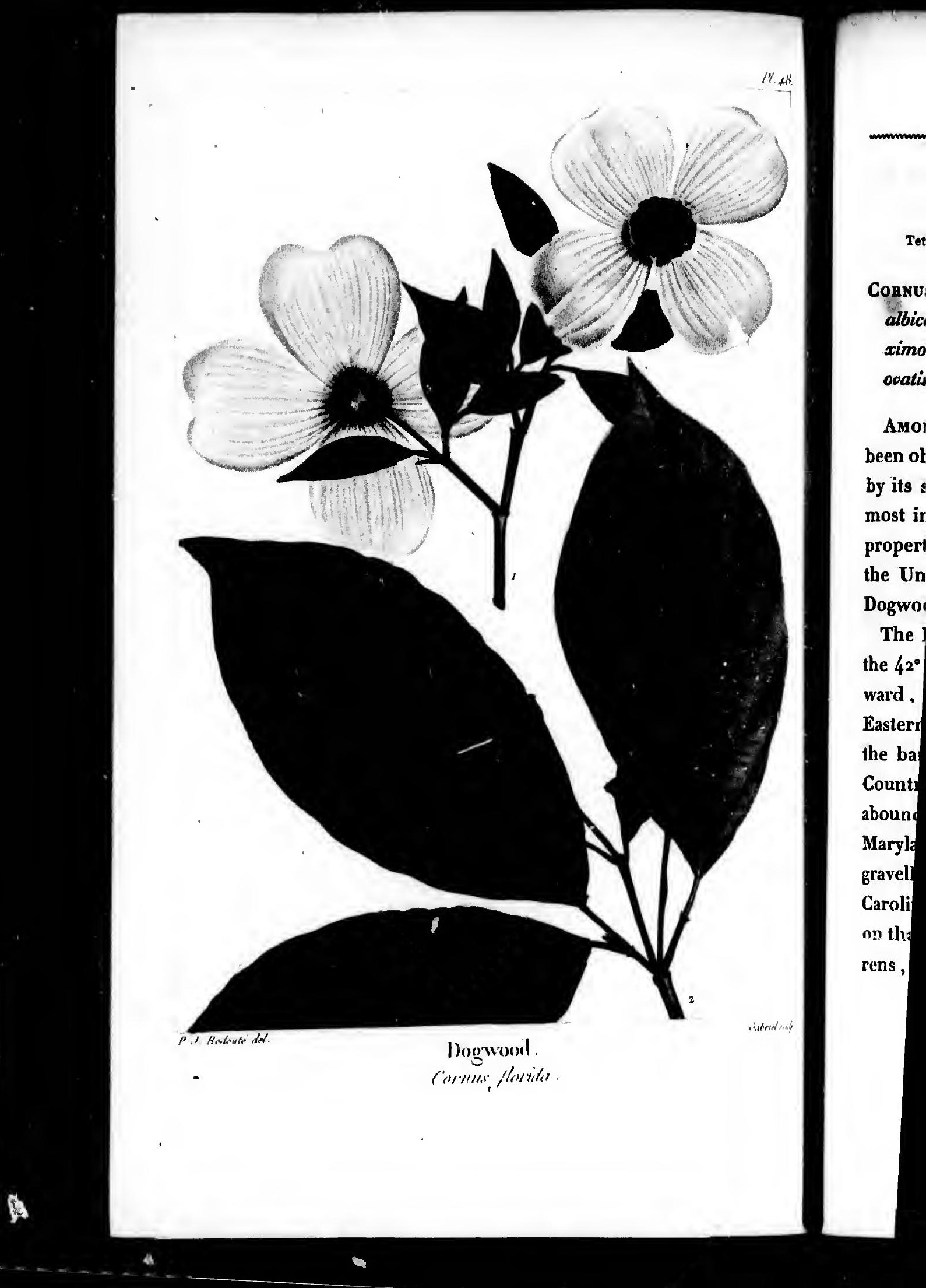


(1)

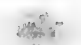

\section{DOGWOOD.}

Tetrandria monogynia, Lıw.

Caprifolia , Jon.

Connus monida. C. foliis ovalibus, acuminatis, subtìs albicantibus: floribus sessiliter capitatis; inpolucro maximo, foliolis apice deformi quasi obcordulis: fructibus ocatis, rubris.

Amove the eight species of Dogwood which have been observed in North America, this alone is entitled by its size to be classed with the forest trees. It is the most interesting, too, for the value of its wood, the properties of its bark, and the beauty of its flowers. In the United States at large, it is known by the name of Dogwood, and in Connecticut it is also called Box Wood. The Dogwood is first seen in Massachusetts between the $42^{\circ}$ and $43^{\circ}$ of latitude, and in proceeding southward, it is met with uninterruptedly throughout the Eastern and Western States, and the two Floridas, to the banks of the Mississippi. Over this vast extent of Country, it is one of the most common trees, and it abounds particularly in New Jersey, Pennsylvania, Maryland, and Virginia, wherever the soil is moist, gravelly, and somewhat uneven ; farther south, in the Carolinas, Georgia, and the Floridas, it is found only on the borders of swamps, and never in the pine barrens, where the soil is too dry and sandy to sustain its 
vegetation. In the most fertile districts of Kentucky and West Tennessee it does not appear in the forests except where the soil is gravelly, and of a middling quality.

The Dogwood sometimes reaches 30 or 35 feet in height, and 9 . or 10 inches in diameter; but it does not generally exceed the height of 18 or 20 feet, and the diame. ter of 4 or 5 inches. The trunk is strong, and is covered with a blackish bark, chapped into many small.portions, which are often in the shape of squares more or less exact. The branches are proportionally less numerous than on other trees, and are regularly disposed nearly in the form of crosses. The young twigs are observed to incline upwards in a semicircular direction.

The leaves are opposite, about 3 inches in length, oval, of a dark green above, and whitish beneath : the upper surface is very distinctly sulcated. Towards the close of summer they are often marked with black spots, and at the approach of winter they change to $a_{0 .}$ dull red.

In New York and New Jersey the flowers are fully blown about the so or 15 of May, while the leaves are only beginning to unfold themselves. The flowers are small, yellowish, and collected in bunches, which are surrounded with a very large involucre composed of 4 white floral leaves, sometimes inclining to violet. This fine involucre constitutes all the beauty cf the flowers, which are very numerous, and which, in their season, robe the tree in white, like a full blown Apple tree, 
cky and except ality. feet in loes not ediame. covered ortions, or less umerous d nearly bbserved

length, leath : the vards the ith black range to $a_{0 .}$

are fully leaves are owers are which are posed of 4 iolet. This e flowers, ir season, pple tree,

and render it one of the fairest ornaments of the American forests.

The seeds of a vivid, glossy red, and of an oval shape, are always united. They remain upon the trees till the first frosts, when notwithstanding their bitterness they are devoured by the Robin, Tundus migratorius, which about this period arrives from the northern regions.

The wood is hard, compact, heavy, and fine grained, and is suceptible of a brilliant polish.The sap is perfectly white, and the heart is of a chocolate colour.This tree is not large enough for works which require pieces of considerable volume $:$ it is used for the handles of light tools such as mallets, small vices, etc. In the country some farmers select it for harrow teeth,for the hames of horses' collars, and also for lining the runners of sledges; but to whatever purpose it is applied, being liable to split , it should never be wrought till it is perfectly. seasoned. The shoots when 3 or 4 years old, are found proper for the light hoops of small; portable casks ; but the consumption in this way is inconsiderable. In the Middle States, the cogs of mill-wheels are made of Dogwood, and its divergent branches are taken for the yokes which are put upon the nerks of swine, to prevent their breaking into cultivated enclosures. Such are the profitable uses of this tree; it affords also excellent fuel, but it is too small to be brought into the markets of the cities.

I. 
The liber or interior bark of the Dogwood is extremely bitter, and proves an excellent remedy in intermitting fevers. It has been known and successfully used by the country people, as a specific in these maladies, for more than 50 years. Its medicinal properties were made the subject of a thesis sustained in the College of Physic at Philadelphia, in 1803 , in which was presented an analysis of the bark of the Dogwood and of the Blue Berried Dogwood, compared with the Peruvian bark: by the experiments made on this occasion, the Dogwood bark was shown to have a close analogy to the Peruvian bark, and to be capable, in many cases, of supplying its place with success. The author of this excellent piece cites a Physician of Pennsylvania, who, during 20 years, had constantly employed it, and who estimated 35 grains of it to be equivalent to 30 grains of the Peruvian bark. The only inconvenience accompanying its use was that, if taken within a year after being stript from the tree, it sometimes occasioned acute pains of the bowels: but this evil was remedied by adding to it 5 grains of Virginia Snake root, Aristolochia serpentaria.

The same author gives a receipt for making an excellent ink in which this bark is substituted for gall nuts : Put 1/2 an ounce of Dogwood bark, 2 scruples of sulphate of iron, and 2 scruples of gum arabic, into 16 ounces of rain water; during the infusion shake it repeatedly.

The Dogwood merits the attention of Europeans, for 
the value of its wood, and especially for the brilliancy of its flowers, by which it is better adapted than almost any other North American tree, to the embellishment of forests , parks, and extensive gardens.

\section{PLATE XLVIII.}

A branch with leaves and flowers of the natural size. Fig. I, A branch with fruit of the natural size.

n bark: gwood eruvian ying its it piece o years, ated 35 ?eruvian use was rom the bowels : rains of 8 an exfor gall scruples bic, into shake it eans, for 
260.

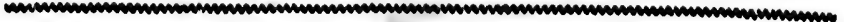

\section{GEORGIA BARK.}

Pentendrie monegynia. Liwn.

Rubiacee. Jese.

Pincreara pubens. P. foliis oppositis, ovalibus, utrinque acutis; subtomentosis.

Obs. Floribus majusculis, pallentibus et purpured-linearibus, fasciculato-paniculatis. Capsulis subrotundis, modicè compressis : seminibus numerosis, alatis.

Tnrs tree, still more interesting by the properties of its bark, than by the elegance of its flowers and of its foliage, is indigenous to the most southern parts of the United States : probably its grows also in the two Floridas and in Lower Iouisiana. My father found it for the first time in 1791 on the banks of the St. Mary. He carried seeds and young plants to Charleston!, and planted them in a garden which he possessed near that city. Though entrusted to an ungrateful soil, they succeeded so well, that in 1807 I found several of them 25 feet high and 7 or 8 incles in diameter; which proves that the vegetation of this tree does not require a very warm climate, nor a very substantial soil.

With a great affinity to the Cinchona which yields the Peruvian bark, my lather discerned in the Georgia Bark sulficient differences, to distinguish it as a new genus. In testimony of his gratilude and respect, he consecrated it to Charles Cotesworth Pinckney, an en- 


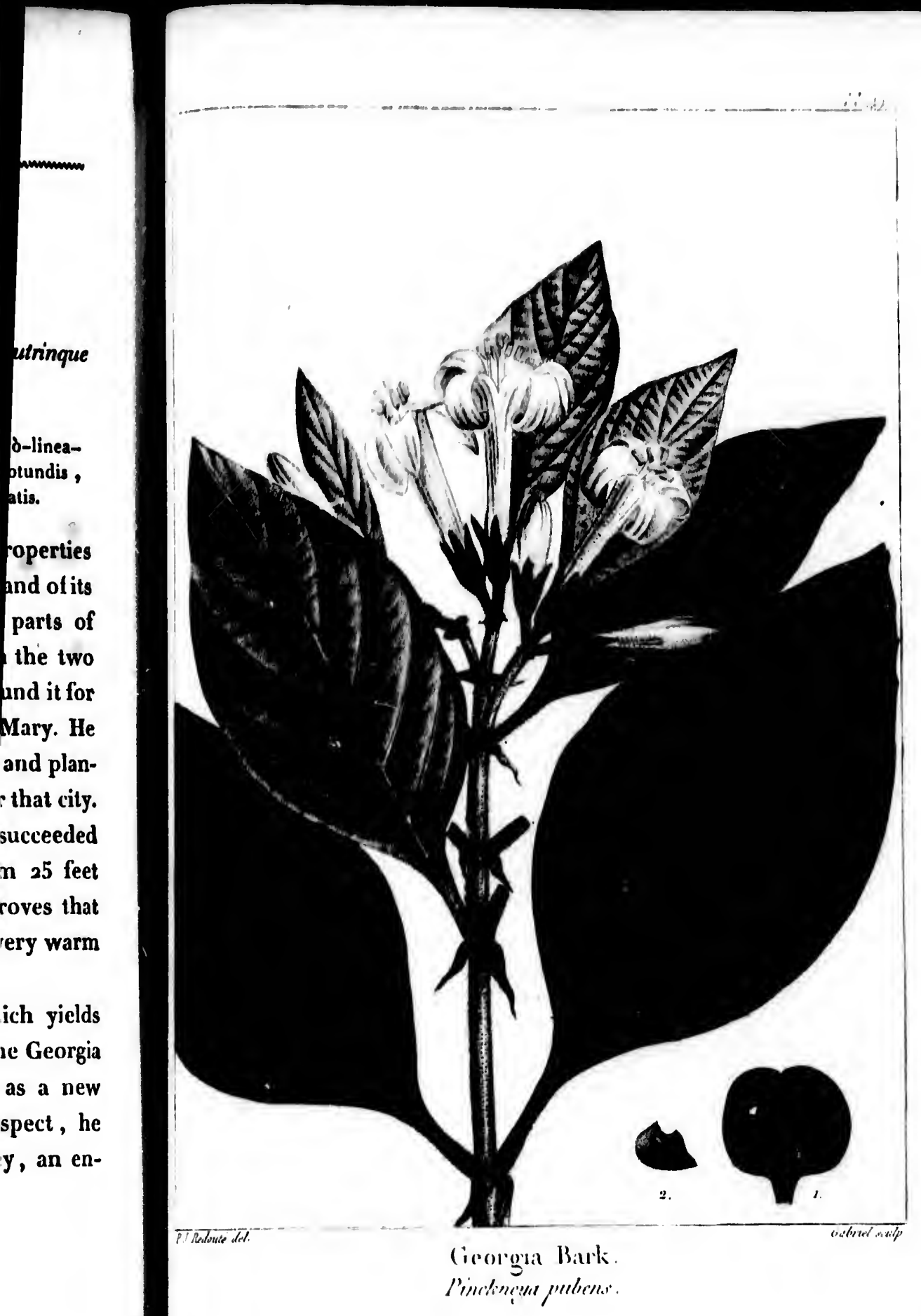


lightene my fath Carolin and esth The numero 25 feet, A cool . to its $g$ t long, of as are al flowers ed strip ful pani flower it rose col round, great nu The use in 1 and app Cinchon Georgis which prevail boiled half, a the pr 
lightened patron of the arts and sciences, from whom my father and myself, during our residence in South Caroline, received multiplied proots of benevolence and esteem.

The Georgia Bark is a low tree, dividing itself into numerous branches, and rarely exceeding the height of 25 feet, and the diameter of 5 or 6 inches at the base. A cool and shady exposure appears the most favorable to its growth. Its leaves are opposite, 5 or 5 inches long, of a light groen solour, and downy underneath, as are also the whools to which they are attached. The flowers, which are white with longitudinal rose coloured stripes, are prelly large, and are collerted in beautiful panicles at the extremity of the sanches. Each flower is accompagnied by a floral le af . bordered with rose colour near the upper euge. The captules are round, compressed in the middle, and stored with a great number of small wingerl seeds.

The wood of the Georgia Bark is soft, and unfit for use in the arts; but its inner bark is extremely bitter, and appears to partake of the febrifuge virtues of the Cinchona, for llse inhabitants of the sonthern parts of Georgia employ it succ:essfully in the intermitting fevers which, during tho the part of summer and the autumn, prevail in the Somllowern Stales. A handful of the bark is boiled in a ynurt of water till the liquid is reduced one half, and :is influsion is administered to the sick. From the properties of its bark the Pinckneya bas taken the 
262

GEORGIA BARX.

name of Georgia Bark. It is to be wished that some intelligent Physician would examine these properties with care, and indicate with accuracy the manner of employing this indigenous remedy, and the effects to be expected from it : the tree which produces it so nearly resembles the Peruvian vegetable, that some Botanists have included them in the same genus.

\section{PLATE XLIX.}

$A$ branch with leapes and flowers of the natural size. Fiz. I, A seed-vessel. Fig. 2, A seed. 


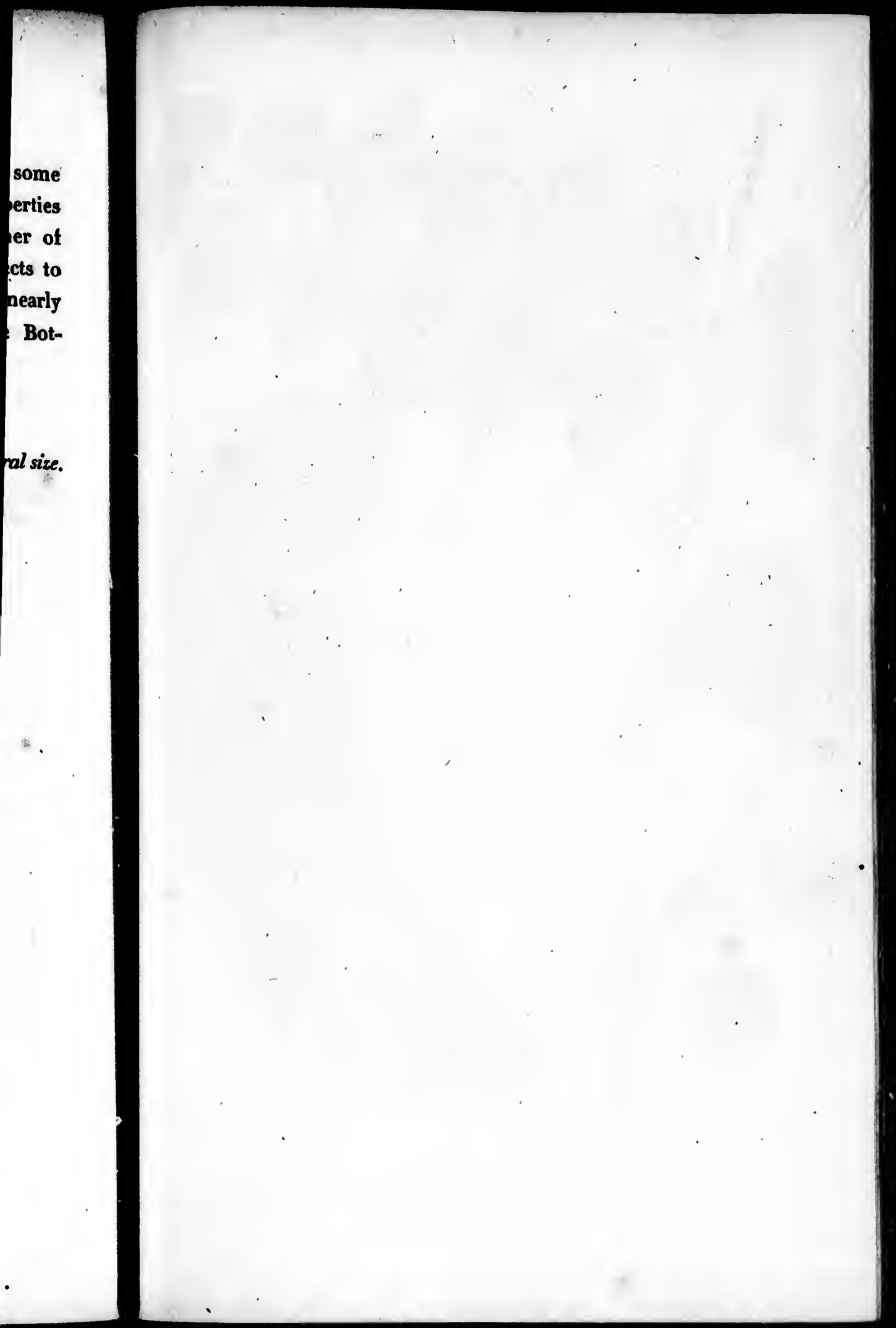




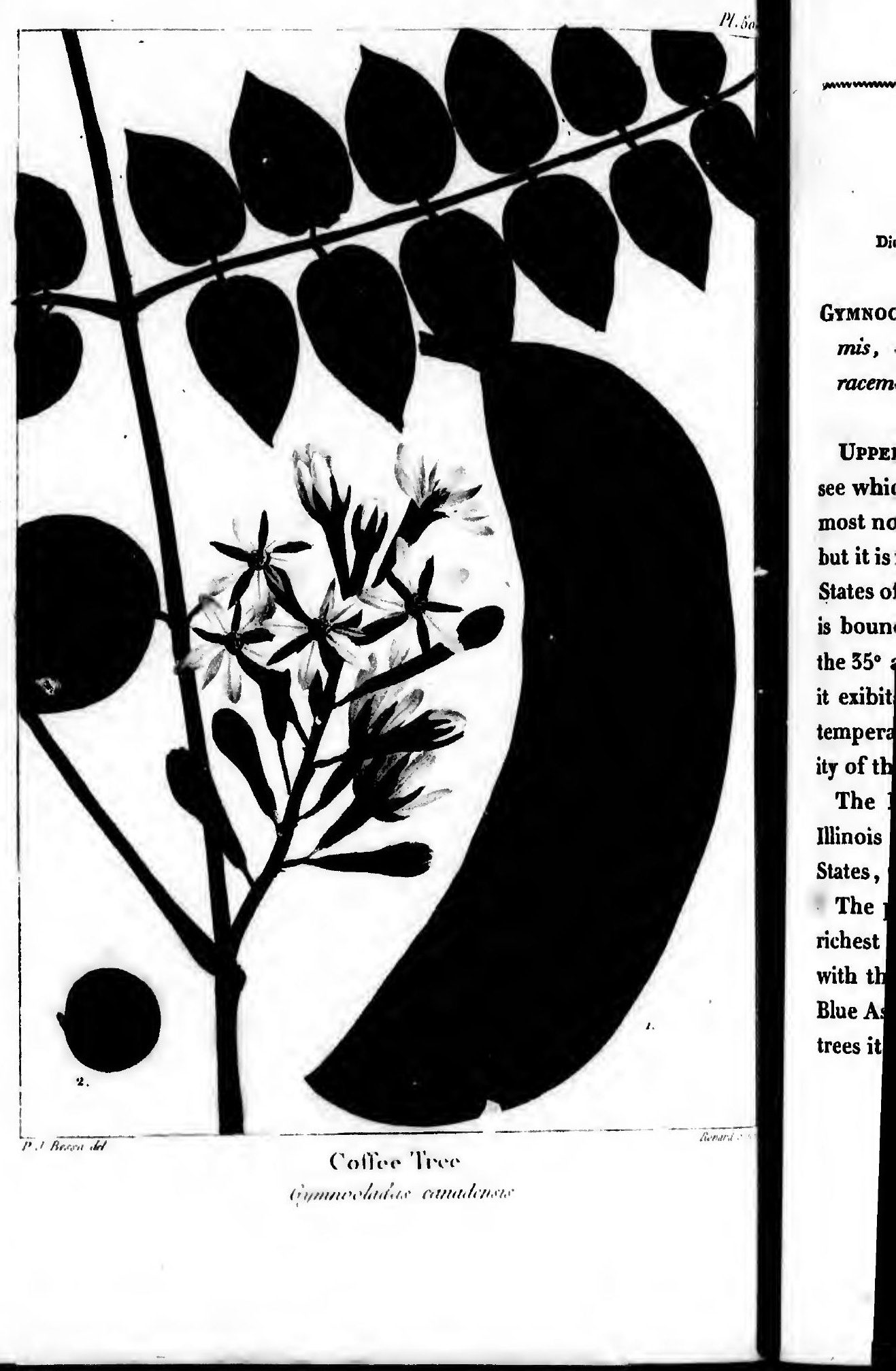




\section{COFFEE TREE.}

Dicecia decandria. Linm.

Leguminose. Jost.

Grmnochadus canadensis. G. foliis bipinnatis, amplissimis, deciduis; foliolis ovalibus, acuminatis. Floribus racemosis; leguminosis polyspermis.

Upper Canadabeyond Montreal, and that part of Genesee which borders on Lake Ontario and Lake Erie, are the most northern countries which produce the Coffee Tree: but it is much less abundant in these climates than in the States of Kentucky and Tennessee, and in the tract which is bounded by the Ohio and Illinois rivers, between the $35^{\circ}$ and $40^{\circ}$ of latitude. The large dimensions which it exibits in these regions is attributable to the milder temperature of the seasons, and to the extreme fertility of the soil.

The French of Canada call this tree Chicot; those of Illinois Gros Fevier; and the Inhabitants of the Western States, Coffee Tree.

The presence of the Coffee Tree is an index of the richest lands.; on which it habitually grows in company with the Black Walnut, the Red Elm, the Poplar, the Blue Ash, the Honey Locust , and the Hackberry. These trees it equals in height, but not in bulk, for a Coffee 
Tree 50 or 60 feet high does not generally exceed 12 or 15 inches in diameter.

In summer this tree when fully grown has a fine appearance : its straight trunk is often destituie of branches for 30 feet, and supports a summit not very widely spread, but of a regular shape and of tufted foliage : such at least is its form in primitive forests, where it is confined by the trees which grow around it. In the winter when its leaves are fallen, the fewness of its branches and the size of the terminal ones, which are very large in comparison with those of other trees, give it a peculiar appearance somewhat resembling a dead tree. This is probably the reason of its being called Chicot, Stump tree, by the French Canadians. To this peculiar character is added another of the epidermis, which is extremely rough, and which detaches itself in small, hard, transverse strips, rolled backward at the ends, and projecting sufficiently to render the tree distinguishable at first sight. I have also remarked that the live bark is very bitter, so that a morcel no bigges than a grain of maize chewed for some time produces a violent irritation of the throat.

The leaves are 3 feet long, and 20 inches wide on young and thriving trees : on old ones they are not more than half as large. These leaves are doubly compound, with oval-acuminate leaflets from $i$ to 2 inches long. The leaflets are of a dull green, and in the fall the petiole is of a violet colour. 
The Coffee Tree belongs to the claes Dioecia of Linnæus, which in:'udes all vegetables whose barren and fertile tlowers are borne by different plants ; in which case those only that bear the fertile flowers produce fruit: to effect the fecundation it is necessary that there should be male plants growing near them. The flowers and the fruit are large, bowed pods, of a reddish brown colour, and of a pulpy consistency within. They contain several large, grey seeds which are extremely hard. The French of Upper Louisiana call them Gourganes.

The name of Coffee Tree was given to this vegetable by the early emigrants to Kentucky and Tennessee, who hoped to find in its seeds a substitute for coffee : but the small number of persons who made the experiment abandoned it, as soon as it became easy to obtain from the sea ports the Coffee of the West Indies.

The wood of the Coffee Tree is very compact and of a rosy hue. The fineness and closeness of its grain fit for cabinet-making, and its strength renders it proper for building. Like the Locust, it has the valuable property of rapidly converting its sap into perfect wood, so that a trunk 6 inches in diameter has only 6 lines of sap, and may be employed almost entire. These qualities recommend it for propagation in the forests of the north and of the center of Europe.

The Coffee Tree was sent to France more than 5o years since. It thrives in the environs of Paris, where there are there are tries that exceed 40 feet in

1. 
height ; but it does not yield fruit, and is multiplied only by shoots obtained by digging trenches round the old trees. The divided roots produce shoots 3 or 4 feet long, the first year. The young trees are sought, on account of their beautiful foliage, for the embellishment of parks and pictoresque gardens.

\section{PLATE L.}

A branch with flowers of the naturnal size. Fig. i, A pod of the natural size. Fig. 2, A seed of the natural size. 


\section{THE \\ 267 .}

\section{NORTH AMERICAN \\ $S Y L V A$.}

\section{MAGNOLIAS.}

$\mathrm{T}$

He trees and shrubs which compose this genus are, without exception, natives of Asia and America, where they are found nearly in the same latitude, being included between the 28 th and 4 2nd parallels.

All the Magnolias are adorned with beautiful foliage, and most of them with magnificent flowers. The species which are indigenous to North America, and particularly those which grow in the southern part of the United States, are in these respects the most remarkable; hence, for more than half a century, they have been highly esteemed in Europe as ornamental vegetables. In the climates of London and Paris, several of the Asiatic and one of the American species require to be sheltered in the winter, to secure them from the danger of perishing by cold:

Of thirteen species of Magnolias which have hitherto been distinctly ascertained, five belong to China and Japan. Of these the Magnolia Yulan is the largest. It 
attains the height of 30 or 40 feet, and its flowers, which are nearly' 6 inches in diameter, diffuse a delicious odour. It has been cultivated during several centuries, and serves particularly for the embellishment of the Emperor of China's gardens. In Chinese poetry it tigures as the symbol of candour and of beauty.

Of the eight remaining species, which are natives of the New Wurld, one belongs to the West Indies, and seven to the United States : others will perhaps be discovered in the Floridas and in the country west of the Mississippi. Two species from America have lately been exhibited as new ones, one of which, called Magnolia pyramidata, bears a close analogy in its foliage to the Magnolia auriculata, and the other, to the Magnolia cordata; but as no bolanist has seen their flowers and fruit, which furnish the only constant specific characters, our opinion on this point must remain sus. pended. It should be remembered that nursery-men are interested in multiplying the species of such exotic vegetables as are esteemed for their beauty, 
wers,

a deli-

1 cenbent of petry it

ives of

$s$, and be disof the ly been agnolia to the agnolia ers and characin susry-men exotic 


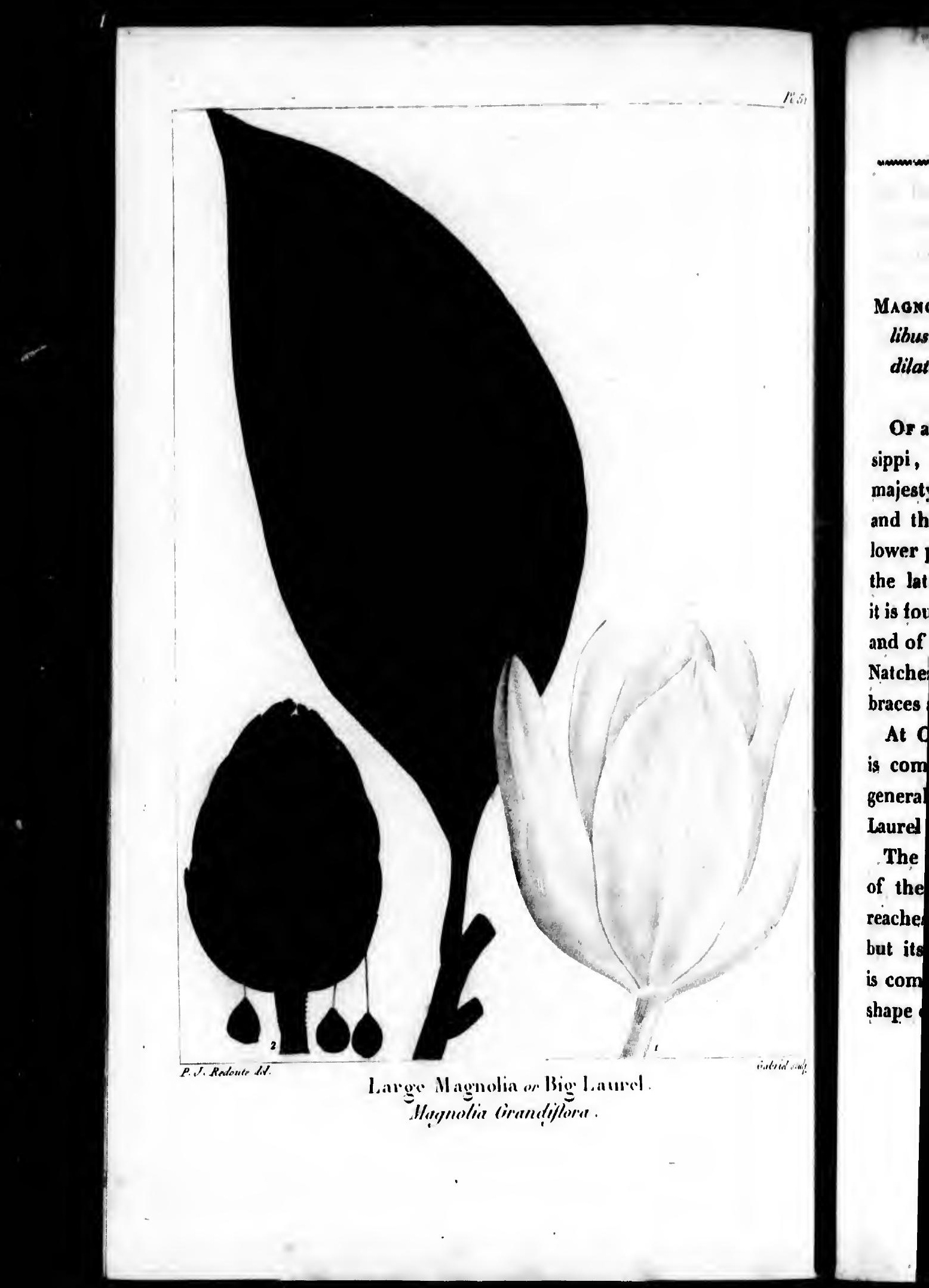




\section{9}

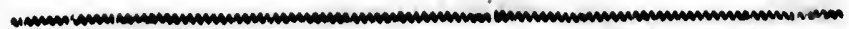

\section{BI G LAU REL.}

Polyandria poliginye. Lawn.

Magnolie, Juse,

Magnozia onawdirzona. M. folits perennantibus, ovalibus, rigidd crassdpue coriaceis; pistillis lanatis, petalis dilatato-ovalibus, abnupte in unguem angustatis.

Or all the trees of North America, east of the Missis. sippi, the Big Laurel is the most ramarkable for the majesty of its form, the magnificence of its foliage , and the beauty of its flowere. It is tirst seen in the lower part of North.Carolina, near the river Nuse, in the latitude of $35^{\circ}, 3 \mathrm{r}^{\prime}$; proceeding from this point; it is found in the maritime parts of the Southern States and of the Floridas, and as far up the Mississippi as Natchez, 3on, miles above New Orleans; which embraces an extent of 2,000 miles.

At Charleston, S. C., and in its vicinity; this tree is commonly called Large Magnolia; but it is more generally known in the country by the name of Big Laurel : the French of Louisiana call-it,Laurier Tulipier.

The Big Laurel claims a place among the largest trees of the United Stalen. It sometimes, though rarely, reaches go feet in height, and 2 or 3 feet in diameter ; but its ordinary stature is from 60 to 70 feet. Its-trunk is commonly straight, and its summit: nearly in the shape of a regular pyramid. It leaves are entire, oval. 
cometimes accuminate and sometimes obtuse at the oummit, 6 or 8 inches long, and borne by short petloles. They are ever-green, thick, coriaceous, and very brilliant on the upper surface. On trees which, for their beauty, have been left standing here and there in clearing the land, the foliage, upon being exposed to the oun, assumes a rusty, ferruginous colour beneath. A similar fact is observed with respect to trees growing on the okirts of the foreats ; the foliage on the side which to open to the smaig ruaty, and on that which is veiled by the neighbouning thes it is of an untarnished green.

The flowers of the Bit Laurel are white, of an agreeable odour, and 7 or 8 inches broad. They are larger than those of any other tree with which we are acquainted, and on detached trees they are commonly very numerous. Blooming in the midst of rich foliage; they produce so fine an effect, that those who have ween the tree on its native soil agree in considering it as one of the most beautiful productions of the vegetable kingdom.

The fruit is a fleshy, oval cone, about 4 inches in length : it is composed of a great number of cells, which, at the age of maturity, open longitudinally, shewing two or three seeds of a vivid red. The seeds soon after quit the cells, and for some days remain suspended without, each by a white filament attached to the bottom of its cell. The red, pulpy substance, which

surrout stone $c$ tree bl beginni

The greyish is cont, serves that it that it this re in the inches betwee deep 1 the cel this of and I ferme taken Tree, criptid The where deep owam and ir a par 
at the hort peind very for their in cleard to the neath. $A$ pwing on de which is veiled arnished

an agreeare larger e are acommonly $h$ foliage, who have ering it as vegetable inches in of cells, tudinally. The seeds main susttached to ce, which

surrounds the slone, decays and leaves it naked. The stone contains a white, milky kernel. In Carolina, this tree blooms in May, and its seeds are ripe about the beginning of October.

The trunk of the Big Lausel is covered with a smooth, greyish bark, recembling that of the Beech. The wood is soft, and remarkable for Its whiteness, which it preserves even ofler it is ceasoned. I have been informed that it is eadly wrought and not liable to warp, but that it is not durable when exposed to the weather : for this reason Bis Inurel bodrdo are used only in joinery in the interior of building. In trees from 15 to 18 inches in diameter, 1 discerted no mark of distinction between the eap and the heart of this wood, except a deep brown point, six or eight lines in diameter, in the centre of the trunk. The trees from which I drew this obcervation had been felled about three weeks, and I remarked that some of the chips, after a slight fermentation, had changed to a rose colour. I have taken notice of an analogous fact in the Poplar or Tulip Tree, which will be particularly mentioned in the description of that tree.

The Big Laurel grows only in cool and shady places, where the soil, composed of brown mould, is loose, deep and fertile. These tracts lie contiguous to the great owamps, which are found on the borders of the rivers and in the midat of the pinebarrens, or form themselves a part of these swamps; but they are never seen in the 
long and marrow marshes; called branch-scocamps, which traverse the barnens in every direction', and in which the miry soil is shallow, with a bed of white, quartzous sand beneath. In the situations mentioned above, it is generally accompanied by the Swamp Chesnut Oak, Spanish Oak, Beech, Wahoo and Devil Wood. I have uniformly remarked that wherever the Big Laurel grows it is accompanied by the Umbrella Tree, but that the Umbrella Tree, which endures an intense degree of cold, is not always accomprnied by the Big Laurel.

The seeds of the 130 Iaurel becume rancid less speedily than those of the duter species of Magnolia ; they may be kept several months before they are sown. This species also furnishes the greatest number of young stocks, which are as thriving as plants carefully raised in the nursery, and so numerous in the districts where the tree abounds, that several hundreds of them may be plucked up.in an hour.

Insulated trees bear a proportionally greater number of blossoms and of cones than those which are enclosed in the forests : a single tree sometimes yields $\mathbf{3 0 0}$ or 400 cones, each of which contains 40 or 50 seeds.

The Big Laurel is deservedly esteemed in Europe by the curious in foreign. vegetables. It is valued, not only for the magnificence of its foliage and of its' flowers, but also for its insensibility to cold. It is hardier than the Orange Tree, and in America it grows tive degrees farther north : the Orange: Tree does not multiply 
s, which which the ous sand ; is geneSpanish niformly s it is acUmbrella 1 , is not ess speedlia ; they own. This of young lly raised ets where hem may

: number enclosed oo or 400 curope by not only 'flowers, dier than c degrees multiply

in the American forests above the $28^{\circ}$ of latitude. In Europe, the most northern point at which the Big Laurel passes the winter/focurely in the open air is about Nantes, in the latitude of $47^{\circ}, 13^{\prime}$; but it begins to yield ripe fruit near Grenoble, in the latitude of $4^{\circ}$, II'. In the garden of the late Mr. W. Hamilton, near. Philadelphia , I saw a Big Laurel which bore uninjured the rigorous climate of this part of Pennsylvania, which is much more severe than that of Paris and of London. From thesefacts it may be inferred that, with time and perseverance, this tree may be hobituated to a degree of cold far exceeding the temperutuse of its native skies, and that it will one day become the tinest ornament of our parks and gardens.

\section{PLATE LI.}

$A$ leaf of the natural size. Fig. $1, A$ flower of half the natural size. Fig. 2, $A$ cone of the natural size. 
$2 \eta 4$.

\section{SMALL MAGNOLIA,}

WHITE BAY.

Magmonia gundca. M. foliis aegualiter ovalibus, vel ovalioblongis; subtics glaucis.

Tars tree, though inferior in size to the preceding species and less regularly formed, is interesting on account of its beautiful foliage and flowers. The Small Magnolia has lately been found near Cape Anne in Massachusets, in the latitude of $4^{\circ}, 50^{\circ}$. It is common in Lower Jersey, and becomes more so in proceeding towards the South. In the maritime parts of the Southern States, in the Floridas and in Lower Louisiana, it is one of the most abundant among the trees which grow in wet grounds. It is not found far in the interior of the country, and in New York, Pennsylvania and Maryland, it disappears 30 or 40 miles north of the capitals of these States. In the Carolinas and in Georgia, it grows only within the limits which I have assigned to the pine-barrens. I do not remember to have met with it in the back part of these States, nor in the country west of the mountains. In Philadelphia and New York, and in their vicinity, this tree is called Magnolia, which denomination has entirely superseded those of Swamp 


of
of Swamp
olia, which
owmmmm
Issigned to
e met with
ve country
vel ovali-
orth of the
n Georgia,
ts of the
wer Loui-
preceding trees
esting on
The Small
Anne in
common

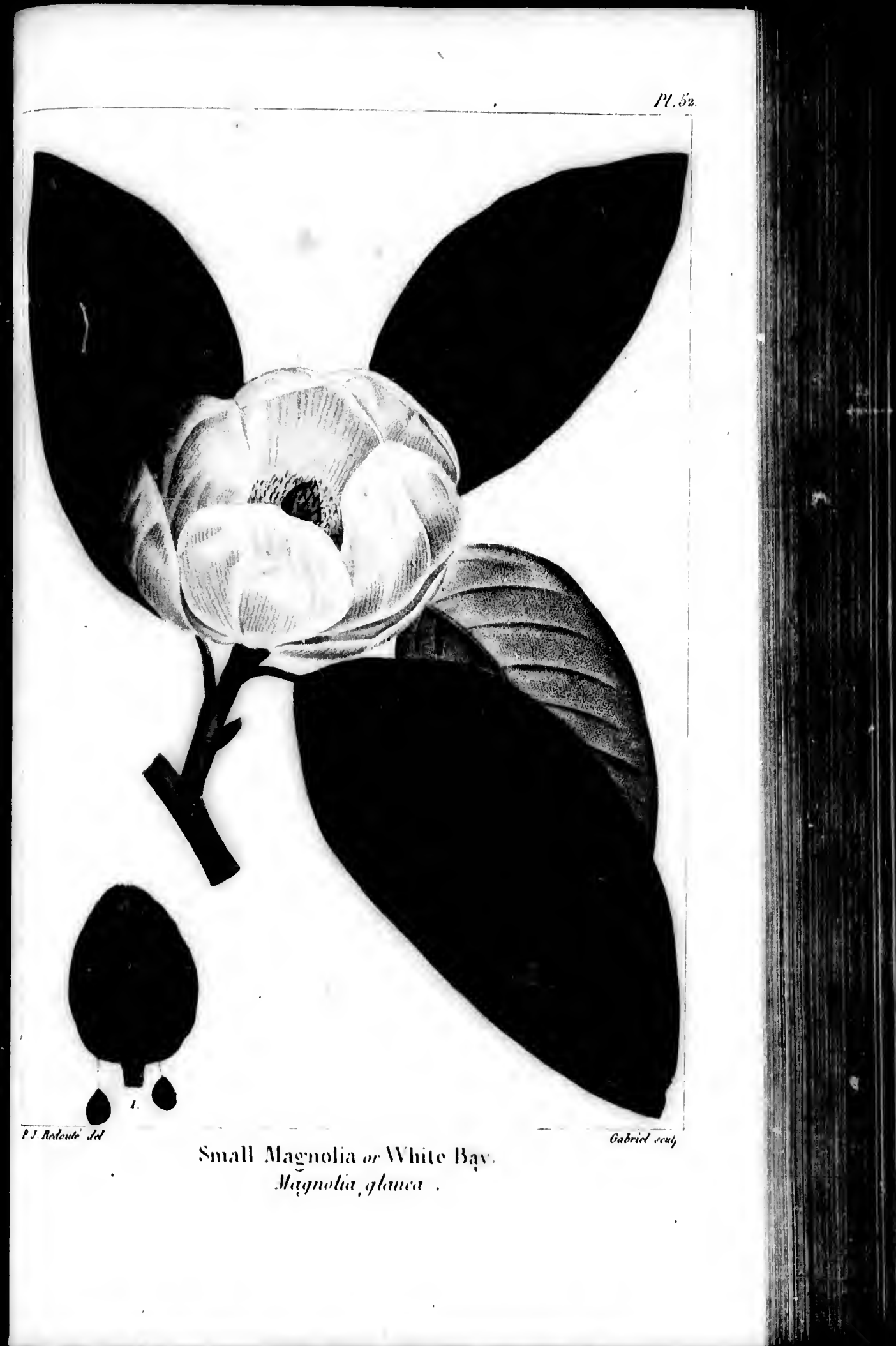


Sassafr the Sw countr White In th and $f a$ the mo of the accom species Carolir large s abund: and $n$ and of of ster constit tioned height but it smalle yields 'The nate, shinin preser two st appea 
Sassafras and Beaver Wood, which were in use among the Swedish settlers who first fixed themselves in the country. In the Southern States it is generally called White Bay or Sweet Bay:

In the lower parts of New Jersey and Pennsylvania, and farther south, the Small Magnolia is seen only in the most miry swamps, which, during the greater part of the year, are so wet as to be impassable. Here it is accompanied by the White Cedar, and by the different species of Andromeda and of Whortleberry. In the Carolinas and in Georgia, it is rarely found in the large swamps which border the rivers; but it grows abundantly, I may almost say exclusively, in the long and narrow marshes which traverse the pine-bairiens, and of which the black and miry soil reposes upon a bed of sterile sand : with the I.oblolly bay and Red Bay. it constitutes the mass of these woods. In the last mentioned States the Small Magnolia sometimes rises to the height of 40 feet, with a diameter of 12 or 14 inches; but it does not ordinarily exceed 20 or 50 feet. It is still smaller about New York and Philadelphia, where it yields fruit at the height of 5 or 6 feet.

The leaves are 5 or 6 inches long, petiolated, alternate, oblong-oval and entire. They are of a dark, shining green above, and glaucous underneath, thus presenting an agreeable contrast in the colour of the two surfaces. The leaves fall in the autumn, and reappear early in the spring. 
The flowers, which are single and situated at the extremity of the branches, are 2 or 3 inches broad, white, and composed of several concave, oval petals. Near Charleston, S. C., the tree blossoms in May, and a month later in the neighbourhood of Philadelphia and New York, where the women and children penetrate into the swamps and gather its sweet-scented flowers to sell them in the markets.

The fruit is small, green and conical, composed of a great number of cellules, and varying in length from an inch to an inch and a half. When ripe, the seeds, which are of a scarlet colour, burst their celis, and remain some days suspended without, by white, lax, slender filaments.

The seeds of the Small Magnolia very speedily become rancid. To preserve for a length of time their faculty of germinating, they must be placel as soon as they are gathered, and before the pulp which envelopes the stone is withered, in rotten wood $L:$ in san slightly moistened, where they are kept cool tili :hey are committed to the ground this is the only mode of cbtaining the tree from the seed. Although the Srnall Magnolia is so abundant in Lower Louisiana, in the Carolinas and in Georgia, young pianis are very rarely met 'vi $h$.

The bark of this tree is smooth and greyish, and its cruesk is always crooked and divided into a great number of divaricating branches. Its wood, which is of a white colour and very light, is employed for no tise. The name

of $\mathrm{B}$

noli

of $t$

and

anim

tion

has :

inhal

mati

the $\mathrm{c}$

and

them

Th

cessf

many

this

of al

equal

beau

in $\mathrm{gr}$

whor

coun

men

A

Fig. 
ted at the es broad, val petals. May, and a elphia and penetrate ed flowers

aposed of a ength from the sceds, celis, and white, lax,

dily become ir faculty of as they are velopes the an: slightly ey are comf cbtaining Magnolia is rolinas and et ' vih.

ish, and its reat number $s$ of a while e. The name of Beaver Wood, formerly given to the Small Magnolia, proves that the Beaver once inhabited those parts of the Middle States to which this tree is indigenous, and that on account of.its softness it was felled by these animals in preference to other trees, for the construction of their dams and houses. The bark of the roots has an aromatic odour and a bitter taste. Some of the inhabilants dirink' an infusion of it in brandy, in rheumatic affections, as a slight sudorific. In Lowèr Jersey, the countr: people steep the cones in rum orin whiskey, and this liquor, which is very bitter, is regardéd by them as a preservative against autumnal fevers.

The Simall Magnolia possesses the advantage of 'successfully resisting the rigorous winters of France, Germany and England. In $18 \mathrm{i}$, a great number of trees of this species yielded ripe seeds in the envirous of Paris. of all indigenous andexotic trees capable of endiuring an equal degree of cold, there is none which rivals it in the beauty of its foliage and of its flowers. It is dèservedly in great request among the amateurs of gardening, $t o$ whom its multiplication, for the embellishment of their country residences, cannot be too warmly recommendëd.

\section{PLA:IE LII.}

A brancli wille leaves and a flower of the natural size. Fig. I, A cone wilh serds of the natiral size. 


\section{CUC:UMBER TREE.}

Magrolia acumrnata. M. foliis ocalibius, anuminatis, subtias pubescentibus; floribus flavo-carnalescentibus

Is all parts of the United States where this tree is found, it is known only by the name of Cucumber Tree. It is a beautiful vegetable, equal in height and in diameter to the Big Laurel. Among the trees of this genus hitherto discovered in North America, these two species alone exhibit very large dimensions. The most northern point at which $I$ have myself observed the Cucumber Tree, is on the Niagara river, near the celebrated cataract of that name, in the latitude of $43^{\circ} ;$ and I believe it does riot exist far beyond this limit. It abounds along the whole mountainous tract of the Alleghanies, to their termination in Georgia, over a

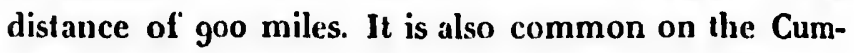
berland Mountains, which divide the State of Tennessee. The situations peculiarly adapted to its growth are the declivities of mountains, narrow vallies, and the banks of torrents, where the atnosphere is constantly moist, and where the soil is deep and fertile. At the distance of 40 or 50 miles from these mountains, either eastward or westward, the Cucumber.'Iree is met with only accidentally upon the steep banks of rivers, where 
acuminatis, sccntibus

this tree is Cucumber cight and in rees of this , these two - The most bserved the ear the celeof $43^{\circ} ;$ and is limit. It tract of the rgia, over a on the Cum: of' Tenness growth are es, and the is constantly rtile. At the tains, either is met with ivers, where

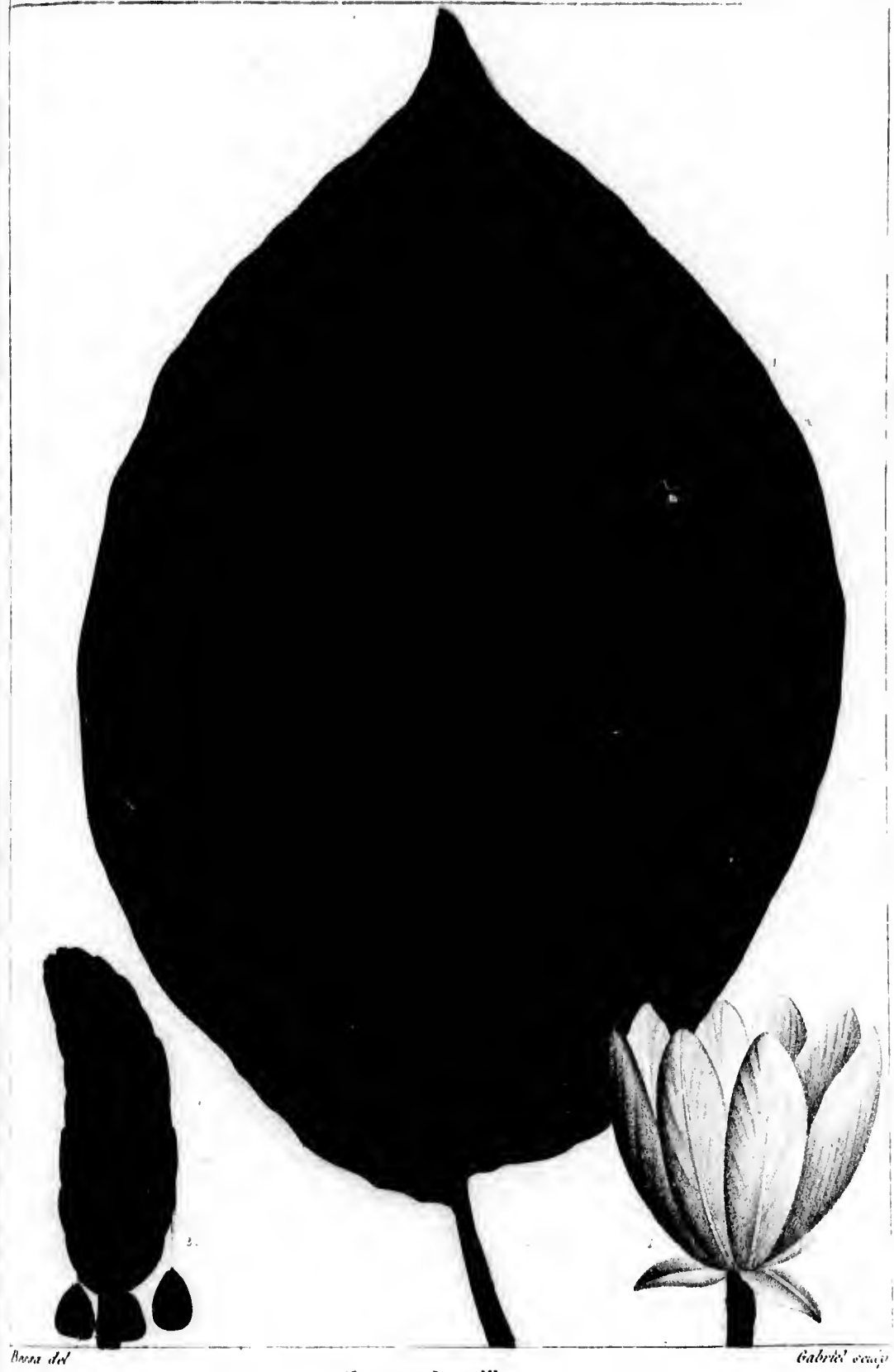

cusumber lines.

Jlagnostia armominala. 
the at ration Wo all the atlant 100 , soil a being the $p$ most the c

'Th long saplit twice acum the 8 Th bluis They num supe TI lines ofler The and whe 
the atmonphere is constantly refreshed by the evaporation from their surface.

We may conclude then that this tree is a stranger to all the regions north of the river Hudson, and to all the atlantic parts of the United States, to the distance of 100,150 and 200 miles from the sea; the nature of the soil and the extreme heat of the climate in summer being utterly uncongenial to its growth. It is also rare in the parts of Kentucky and West Tennessee which are most remote from the mountains, where the face of the country is less uneven.

The leaves of the Cucumber Tree are 6 or 7 inches long, and 3 or 4 inches broad, upon old trees ; upon saplings growing in moist places they are sometimes twice as large. 'Iheir form is oval, entire, and very acuminate: they fall in the autumn and are renewed in the spring.

The flowers, which are 5 or 6 inches in diameter, are bluish, and somelimes white with a tinct of yellow. They have a fecble odour, but as they are large and numerous, they lowe a fire effect in the midst of the superb loliags..

The cones or fruit are about 3 inches long, 8 or 10 lines in diamelor, of nearly a cylindrical shape, and often a little larger at the upper end than at the base. They are convex on one side and concave on the other, and when green they nearly resemble a young cucumber, whence the trec lass derived its name. The cells are 


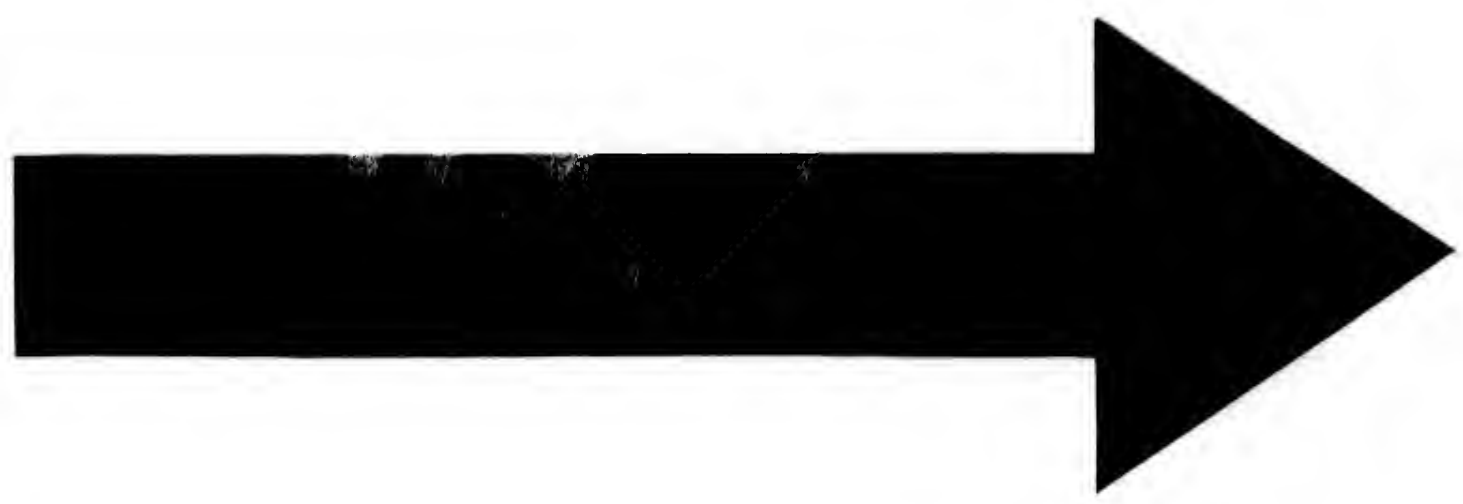




\section{IMAGE EVALUATION \\ TEST TARGET (MT-3)}
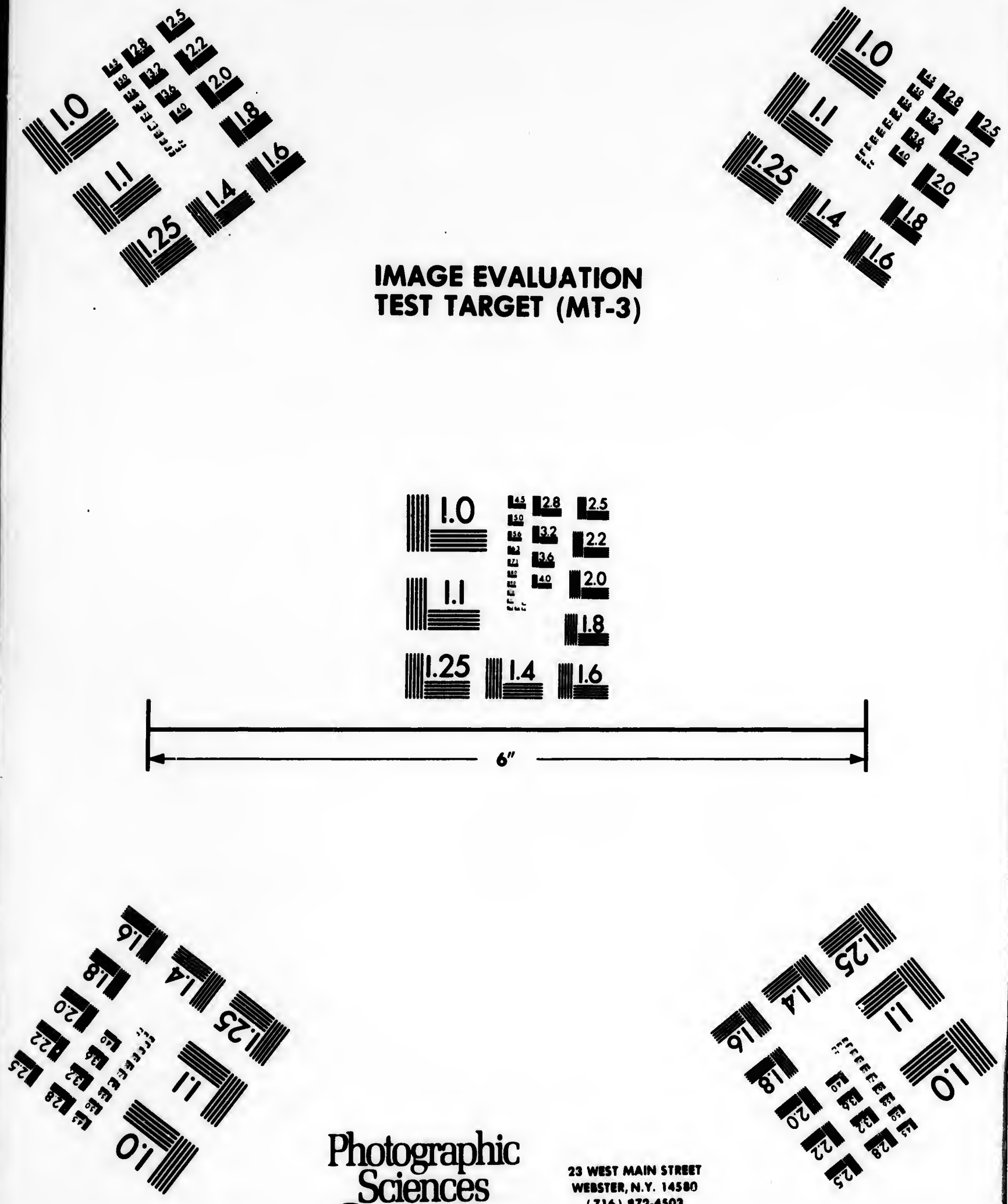

Photographic

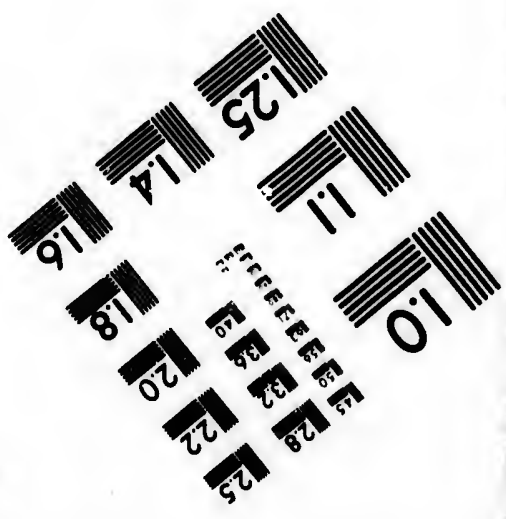


arranged as in the other species of this genus, and each of them contains one rose-coloured seed, which, before it escapes, remains suspended like those of the Great and Small Magnolias. Most of the inhabitants of the courttry bordering on the Alleghanies gather the cones about midsuminer, when they are half ripe, and steep them in whiskey : a glass or two of this liquor, which is extremely bitter, they habitually take in the morning, as a preservative against autumnal fevers. Its efficacy I do not deny, but it has not been made sufficiently evident to induce, any physician to attempt its verification.

The Cucumber Tree sometimes exceeds 80 feet in height, and 5 or 4 feet in diameter at the same number of feet from the ground. The trink is perfectly straight, of an uniform size, and often destitute of branches for two thirds of its length. The summit is ample and regularly shaped, and the tree is one of the finest in the American forests. On old stocks the bark is greyish and deeply furrowed. The heart or perfect wood' is soft, and of a yellowish brown colour, bearing, in this respect, some analogy to the Poplar or Tulip Tree. Like the poplar wood, it is fine grained and susceptible of a brilliant polish ; but it is less strong and less durable when exposed to the weather. Being a rare tree, it is only accidentally employed in the arts. Sawn into boards, it serves in joinery for the interior of wooden houses, and, for its size and lightness, it is selected for large canoes. As its wood possesses no properties which fit it for any deter- 
minate use, the Cucumber Tree is esteemed only becruse its foliage and flowers render it ornamental, and because, like the other trees of this genus, it blooms at an early age. Like the Small Magnolia, it passes unipjured the rigorous winters of England, Germany and the North of France, and flourishes and blooms in the open fields. The seeds, it is true, seldom ripen; but when the trees become a little older, if proper attention is bestowed upon selecting for them a shaded southern exposure, we may hope to see their fruit arrive at maturity.

\section{PLATE LIII.}

1 leaf of the natural size. Fig. i; $A$ flower of half the natural size. Fig. 2, A cone with seeds of the natural size. 


\section{HEART-LEAVED CUCUMBER TREE.}

MAGNoha condata: M. foliis condatis, subtics subtomentasis; foribus fluois.

Trts species of Magnolia, which, in its general appearance and in, the form of its:fruit, very nearly resemables the preceding, has been confounded with it by the inhabitants of the regions in which it grows; hence it has received no distinguishing name, and, to supply the defect, I have given it that of Heart-leaved $\mathrm{Cu}$ cumber Tree.

The banks of the river Savannah in Upper Georgia, and those of the streams which traverseg the back parts of South Carolina, are the places where my father and myself particularly observed this tree. The nearest point to the sea at which I have found it, is the plantation of Good-rest, 12 miles from Augusta, where, in my last journey in the United States, I noticed it along the sides of Horn Creck. The Heart-leaved Cucumber Tree is 40 or 50 feet in height, and 12 or 15 inches in diameter. Its trunk is straight, and covered with a rough and deeply furrowed bark, very much resembling that of the Sweet Gum and of the young White Oak. Its leaves, which are borne upon long petioles, are from 4 to 6 inches in length, from 3 to 5 inches wide, smooth and entire. The flowers, which appear in April, are yellow, with the 


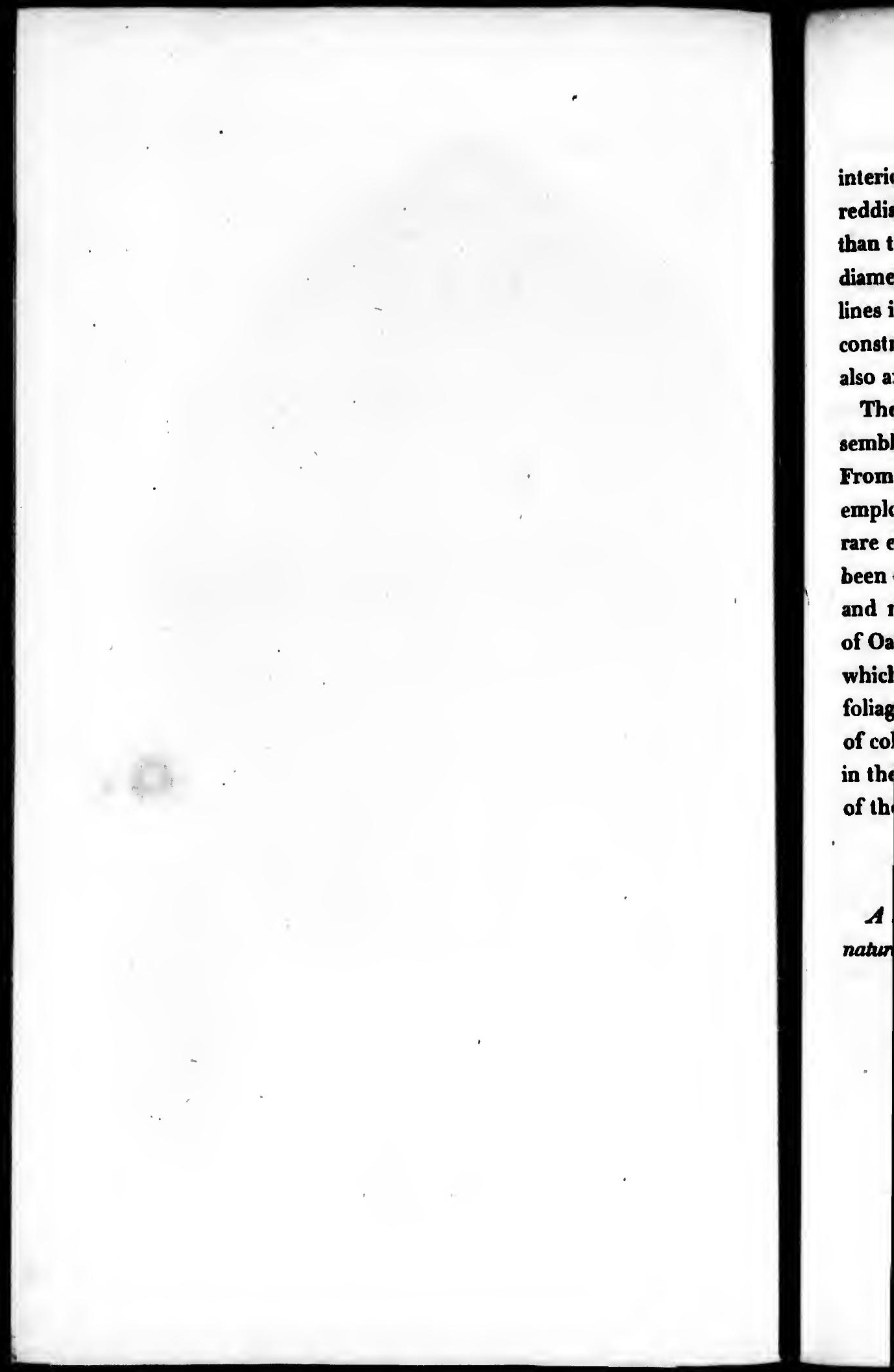


interior of the petal longitudinally marked with several reddish lines. These flowers, though somewhat smaller than those of the Cucumber Tree, are nearly 4 inches in diameter. The cones are about 3 incheslong and 10 or $x a$ lines in thickness, of a cylindrical form, and of a similar construction to those of the other Magnolias. The seeds also are similar in colour and arrangement.

The wood of the Heart-leaved Cucumber Tree : resembles, in every respect, that of the Cucumber.Tree. From its softness and its readiness to decay, it is not employed for any determinate use. Besides, the tree is rare even in Upper Georgia , being found, as has already been observed, only on the elevated banks of the rivers, and never making its appearance in forests composed of Oaks, Walnuts, etc. The beauty of its yellow flowers, which form an agreeable contrast with its luxuriant foliage, and the advantage of resisting an intense degree of cold, are its only recommendations to amateurs : but in these respects it deserves, as well as any other speciea of the genus, to figure in parks and gardens.

\section{PLATE LIV.}

$A$ leaf of the natural size. Fig. $1, \mathcal{A}$ flower of half the natural sze. Fig. 2, 4 cone with seeds of the natural size. 


\section{UMBRELLA TREE.}

Magnolia thipetala. M. Jotiis amplioribus, oblongis, subcuneato-obovalibus, calice reflexo.

On. Potala colito norets.

The Umbrella Tree is first seen in the northern part of the State of New York; but it is more multiplied farther south, and is commun on some of the islands in the river Susquehannah; and still more so in the Southern and Western Stales. It is found in the maritime parts of the Carolinas and of Georgia, and 300 miles from the sea, on that part of the Alleghanies which traverses these States. The forests which cover the banks of the river Nolachachuky, in East Tennessee, may be particularly mentioned as abounding in the Umbiella Tree. Though this tree grows naturally ower a great extent of country, it is not met wilh at every step in the woods like the Witch Harcl, the Dog Wood, and certain species of Oak : it appears only in situations perfectly adapted to its growth, which are always shady, and where the soil is decp, strong and fertile. Thus, in the lower parts of South Carolina and of Georgia, it is found only near the great swamps which lie along the rivers, or which are enclosed in the pine-barrens. Here, it is almost invariably accompanied by the Big Laurel, Swamp Chesnut Oak and Sweet Leaves, and never by 
the Sms grow in of whicl The I genus, of its flc form a trees of the heig inches, thin, 0 are 18.0 are ofte shoats, meter: I. have a in an ir being la with am growing The compose at the though odour th The c inches iv ber, anc 
the Small Magnolia, Red Bay and Loblolly Dry; ; which grow in the small,wwamps that intersect the bairrens, and of which. the soil is shallow, black, and often miry: if:

The Umbrulla:Tree, like the following species of this genus, is remarkable for the largeness of its leaves and of its flowers. The dimensions of the tree are sucless to form a connecting link between the larger/ sbrubs and trees of the third order; for though it sometimes, rises to the height at 30 or 35 feet ${ }_{r}$, with a diameter of 5 or 6 inches, it rarely attains this size. Its. leaves, which are thin, oval., entire and acuminate at both extremities, are 18.or 20 inches long, and 7 or 8 inches broad; they are often disposed in rays at the extremity of vigorous shoats, and thus display a surface of 30 inches in dian meter : whence is derived the namo of Umbrella Treer Lhave almost uniformlv remarked that the trunk grows in an inclined diregtion; the young and feeble stack being laden, before it is as large as the little finger, with ample foliage, is bent by the winds, even when growing in sheltered situations.

The flowers are 7 or 8 inches in diameter, white, composed of several oblong, concave petals, and situated at the extremity of the branches:; they are beautiful, though less regularly shaped and of a less agreeable: odour than those of the other species of Magnolia.

The conical fruit is 4 or 5 inches long, and about 2 . inches in diameter; it ripens in the beginning of October, and is of a beautiful rose colour, with seeds of a 
palo red. Well grown and perfectly formed cones contain So or 60 coeds, which, as they upeedily become sancid, chould be sown immediately after they are gathered. A frat number of young plants may in this way be cally obtained. By keeping the seodo in moss constantly molf 9 they may be preserved for several months.

The wood of the Umbrella Tree is soft, porous, and unde for nes. 'The bork upon the trunk is grey, amooth ind poliwhed : if cut while green, it exhales a diagree. ublo odnus.

This Magnolia, which resists an extreme degree of cold, hes long been cultivated in pleasure grounds in France and Dogland. It is remarkable among all the indigenous tries of Eurcupe, for the size and form of its leavis and flowers. For many years it has yielded prolific sceds in this quarter of the world, so that it is ho longer becenaning to go in quest of it to its native climate.

\section{PLATE LV.}

Aloof of a fourth part of the natural size. Fig. 1, A petal of the natural sice. Fig. 2, A cone with seeds of the natural ates. 



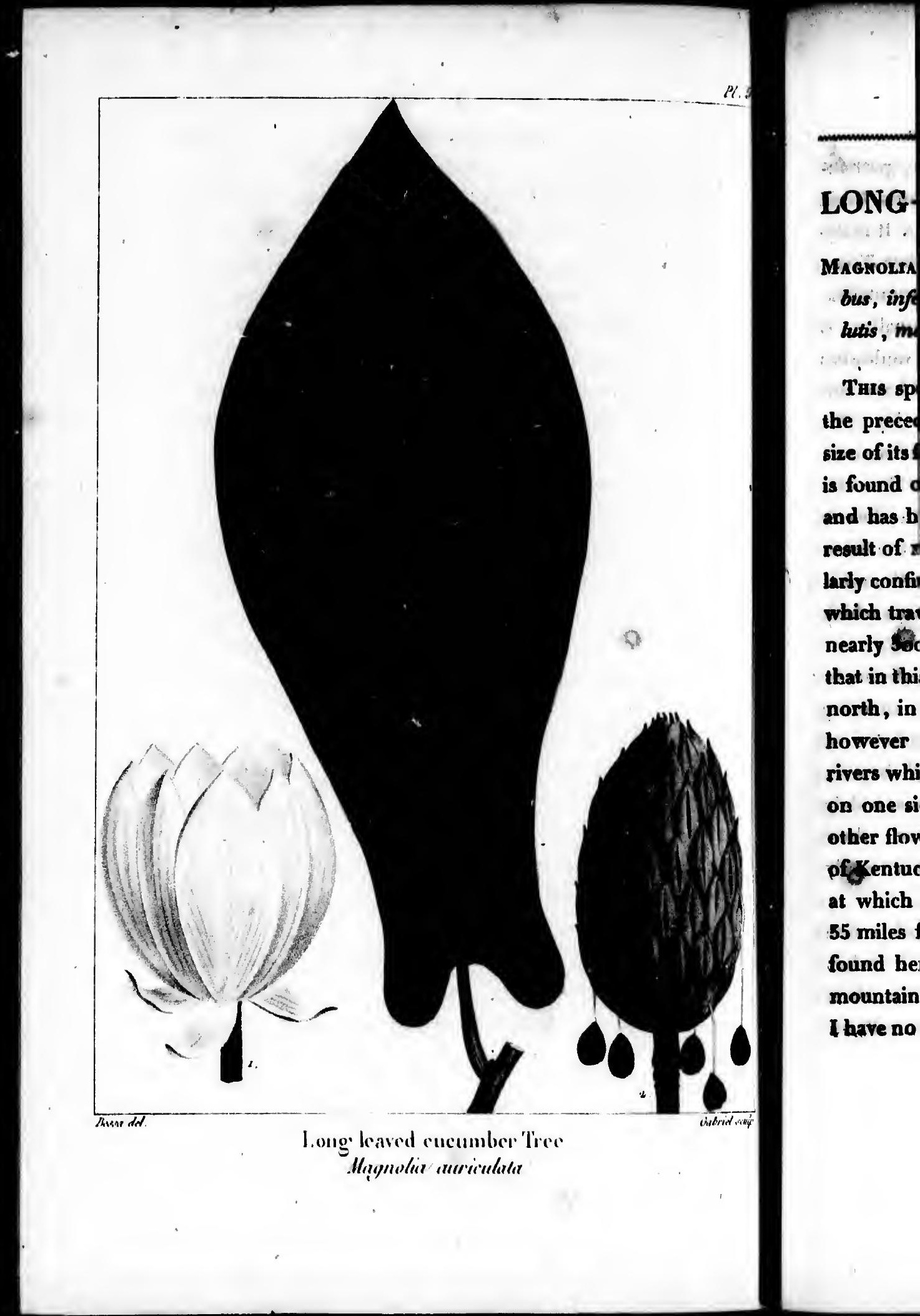


$a$

\section{LONG-LEAVED CUCUMBER TREE.}

Magnozta avincuzata. M. folïs subrhomboideo-obooalibus, inferme angustatis, basi profiundo sinus quasi auriculutis, membranaceis utrinqud-oiridibus.

Turs species of Magnolia, equally remarkable with the preceding for the beauty of its foliage and for the size of its flowers, which are also of an agreeable odour, is found only in a small tract far retired in the country, and has but lately become known to Botanists. As the result of my own researches, it appears, to be particularly confined to that tract of the Alleghany Mountains which traverses the Southern States, at the distance of nearly 30 miles from the sea. It should be remarked that in this part the chain is much broader than farther north, in Virginia. The Long-leaved Cucumber Tree is however sometimes found on the steep banks of the rivers which rise in se lofty mountains, and which on one side roll their waters to the sea, and on the other flow to meet the Ohio, after traversing the States pf Kentucky and Tennessee. The point nearest the sea at which I have met with it is Two Sisters? Fenry, about $\mathbf{5 5}$ miles from Savannah in Georgia : but it seems to be found here only by accident, for from this spot to the mountains, a distance of 150 miles, it is no more scen. I have no where found it as abundant as on the steepest 
part of the lofty mountains of North Carolina, particularly those which are called by the inhabitants Great Father Mountains, Black and Iron Mountains. It is designated by the names of Long-leaved Cucumber Tree, and of Indian Physic. The soil of these mountains, which is brown, deep, and of an excellent quality, is peculiarly favourable to its growth, and it multiplies spontaneously with such facility, that I could have collected a thousand young plants in a single day. The Black Oak, the Scarlet Oak; the Red Oak, the Chesnut, the Red Ash, the Buck's Eye, the Cucumber Tree and the Sorrel Tree compose the remainder of the forests which shade these solitary retreats, where, in the finest days of summer, the atmosphere is charged with moisture by evaporation from the numberless torrents which tumble from the summits.

24.

The Long-leaved Cucumber Tree is much inferior in size to most of the Trees with which it grows, attaining only the height of 40 or 45 teet, and the diameter of 12 or 15 inches. Its. trunk is st ht and well shaped, and often undivided for half its length ; its limbs, widely spread and sparingly ramified, give to the tree, when stript of its leaves, so peculiar an air, that it is readily distinguished.

The leaves are of a light green colour, of a fine texture, 8 or 9 inches long, and from 4 to 6 inches broad; on young and vigorous trees they are often one third or even one half larger. They are smooth on 
IONG-IEAVED CUCUMBER TREE:

both surfaces, acuminate at the summit, widest' near the top and narrowest towards the bottom. The base is divided into rounded lobes, whence is derfived the specific name of Auriculata.

The flowers are 3 or 4 inches in diameter, of a fine white colour, of an agreeable odour, and situated at the extremity of the young shoots, which are of a purplish red dotted with white.

The cones are oval, 3 or 4 inches long, and, like those of the Umbrella Tree, of a beautiful rose colour when ripe. They differ from those of the other species by a little inferiority of size, and by a small appendage which terminates the cells. Each cell contains one or two red seeds.

The wood is soft, spongy, very light, and unfit for use. The bark is grey, and always smooth even on the oldest trees. When the epidermis is removed, the cellular integument, by contact with the air, instantly changes from white to yellow. The bark has an agreeable aromatic odour, and an ingsion of it in some spirituous liquor is employed as an excellent sudorific in rheumatic affections.

The Long-leaved Cucumber Tree flourishes in the open fields in the neighbourhood of Paris and of London. It is becoming common in Europe in the gardens of amateurs of foreign vegetables, who justly prefer it to the Umbrella Tree on account of its flowers, which, though smaller, have the advantage of an agreeable 


\section{0}

LOKG-LEAVID COGOMAER TAER.

perfume. This tree hardily sustains the rigour of the wintem of Rhiladel phia : several stophe sent by my father trone the Mountains of North Caralina to Mesors.W. Eumilton and Bartram, who reside near that city, succeed perfectly in the open garden, and have for several sears bloomed and yielded seed. The useful and agreeable productions which seem to have been confined by the hand of nature to a single district, are thus propagated from one extremity of the globe to the other, and serve; by the innocent pleasure attending their cultivation, to solace the afflictions of humanity.

\section{PLATE LVI.}

1 leaf of a fourth part of the natural size. Fiz. $1, A$ flower of two thinds of the natural size. Fib. 2, A cone with seeds of the natural size. 


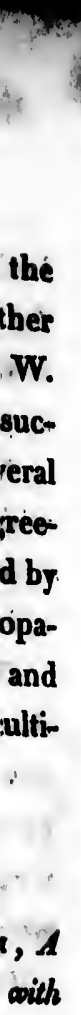




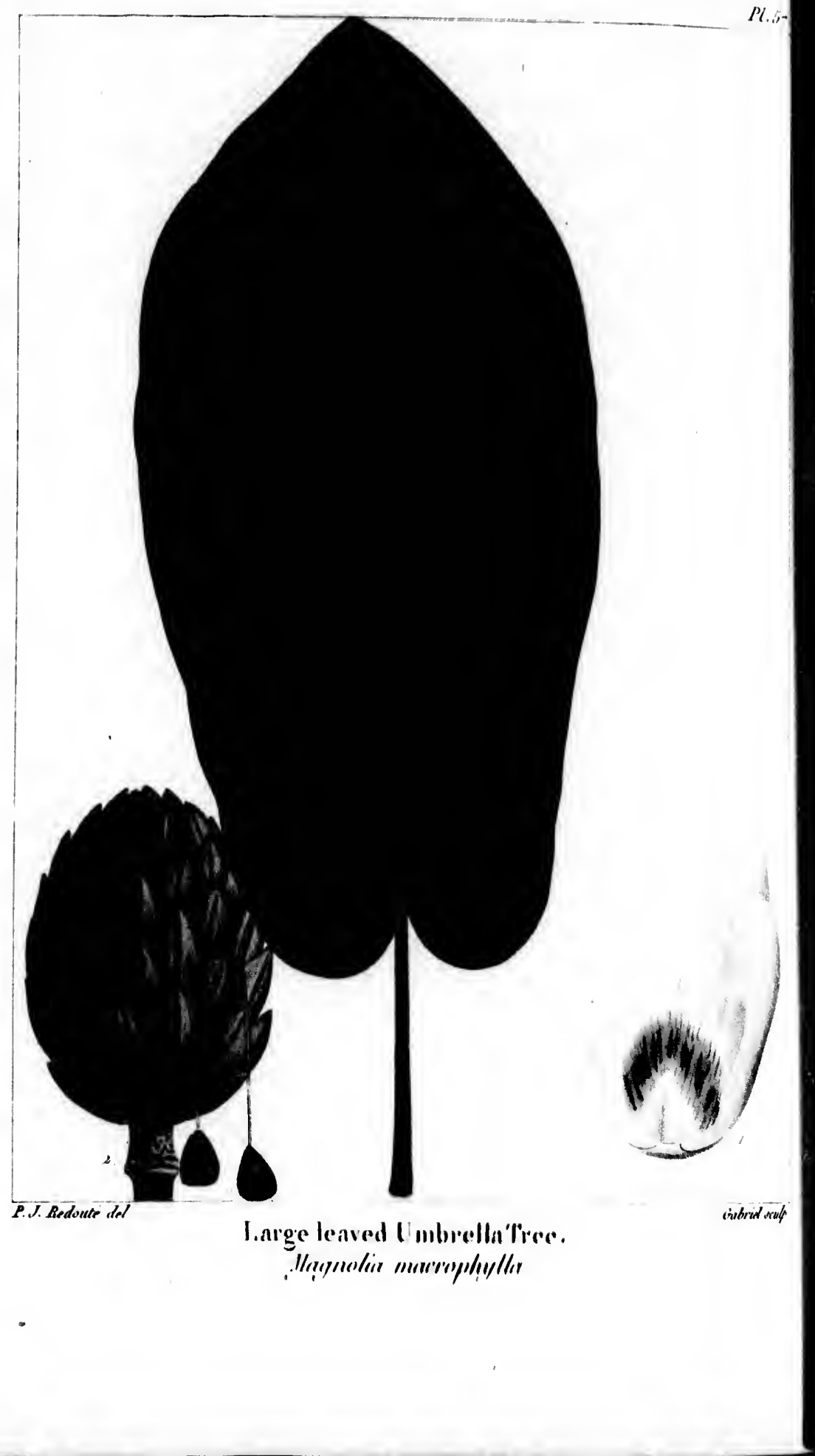

\section{LARGE}

Magnotu foliis om bus, bas ribus arg Or the $t$ on the $\mathbf{O}$ Umbrella leaves and the Ameri forests. Or those of th to been cor which they name of $L$ ently chara ricana, as it by the $n$ umbrella and someti Magnolia i specifio; na to retain $t \mathrm{l}$ : In the $m$ by my fat 


\section{LARGE-LEAVED UMBRELLA TREE.}

MAgNoUda microphyLA. $M$. ramis medullosis, fragilibus; foliis omnium umplissimis, oblongè subcuneato-obovalibus, basi sinuatd, subauriculatis, subtis glaucis; junioribus argenteis, densissimè holosericeis.

OF the twelve species of Magnolia hitherto dicovered on the Old and New Continents, the Large-leaved Umbrella Tree is the most remarkable for the size of its leaves and of its flowers. It is also the least multiplied of the American species, and is rarely met with in the forests. On account of the resemblance of its leaves to those of the Umbrella Tree, the two species have hitherto been confounded by the inhabitants of the districts in which they grow : I have, therefore, given it the specitic: name of Large-leaved Umbrella Tree, which is sufficiently characteristic. My father in his Flora Boreali-Americana, as well as many succeeding botanists, designates it by the name of Magnolia macrophylla, I Large-leaved Umbrella Tree, while in the catalogues of gardeners, and sometimes in those of botanists, it is denominated Magnolia Michauxii. I have thought proper to drop this specific: name, however honourable to my father, and to retain the one which he himself had established.

In the month of June, ${ }_{1.789}$, in the first journey made by my father from Charleston to the Mountains of 
North Carolina, I accompanied him, and discovered this tree', which he immediately judged to be a new species of Magnolia. The spot on which we found this magnificent vegetable is in North Carolina, 10 miles south of Jincolnton, and 250 miles from Charleston. Our extensive researches in queut of it in the upper part of the Southern States, and those subsequently marde by several English botanists eust of the Alleghanies, which were alike unsuccessful, sufficiently prove that it is extremely rare between the mountairs and the sea. West of the range, in Tennessee, it is more common; but even heire only a few trees are found together, at intervals of 40 or 50 miles; as I had an opportunity of observing during my journey in the Western States in 1803.

The Large-leaved Umbrella Tree, like the Umbrella Tree, on which it is a constant atlendant, delights in cool situations sheltered from the wind, where the soil is deep and tertile. In its general appearance, and in the terminal arrangement of its leaves, it most nearly resembles the species just mentioned; in the conformation of the inferior surface of the leaf, it is more like the Long-leaved Cucumber 'I'ree. It forms also a mean between these two species by its size, which does not exceed 35 feet in height, and 4 or 5 inches in diameter. The body of the tree is covered with a smooth and very white bark, by which in the winter, when stript of its leares, it is readily distinguished from the Umbrella 
Tree. At this season it differs also from the Umbrella Tree in its buds, which are compressed instead of being rounded at the end, and which are covered with a soft and silvery down.

Of all this genus, the Large-leaved Umbrella Tree is the species which bears the largest leaves : some of them are 35 inches long, and 9 or 10 inches broad. They are borne on petioles, short in comparison with the size of the leaves, and are of an oblong-oval shape, pointed at the extremity, and cordiform at the base : their colour is light green above, and.glaucous beneath: they fall in the autumn and reappear early. in the spring: The flowers are white and larger than those of any other species of Magnolia, for when fully blown they are sometimes: 8 or 9 inches in diameter: they are composed of six petals, longer and broader than those. of the Umbrella Tree. Within the flower, near the bottom of the petals, $:$ is a purple spot 7 or 8 lines in diameter. The flowers diffuse a fragrant odour, and their beauty is heightened by the luxuriant foliage which surrounds them.

'The cones are about 4 inches long, nearly cylindrical, and of a vivid rose colour when arrived at maturity. In the arrangement of the cells and of the seeds, they resemble those of the Umbrella Tree and of the Longleaved Cucumber Tree : it should be remarked, however, that they are destifute of the appendages visible on the fruit of the last mentioned species, especially when it is dry. 
The seeds of the Iarge-leaved Umbrella Tree require; in order to preserve their power of germination, the eame attention with those of the preceding species.

The wood of this tree is softer and more porous than that of the Umbrella Tree, and is of no value in the arts : like many other plants, its only use is to adorn the garden, and to add another charm to the rural retreat. For this purpose only it is eagerly sought for in France and in England by the lovers of exotic trees, and with the more reason as it passes the winter uninjured in the climates of Paris and of London. $A$ tree of this species which I brought from America seven jears ago, bloomed in 1811 in the gardens of the Empress Josephine at Malmaison.

The Large-leaved Umbrella Tree might be grafted by approach or by innculation on stocks of the Umbrella Tree, which is far more common : an experiment of this sort, made by my father in his garden near Charleston, S. C., was crowned with complete success.

\section{PLATE LVII.}

A leaf of a ffth part of the natural size. Fig. 1, A petal of half the nalural size. 



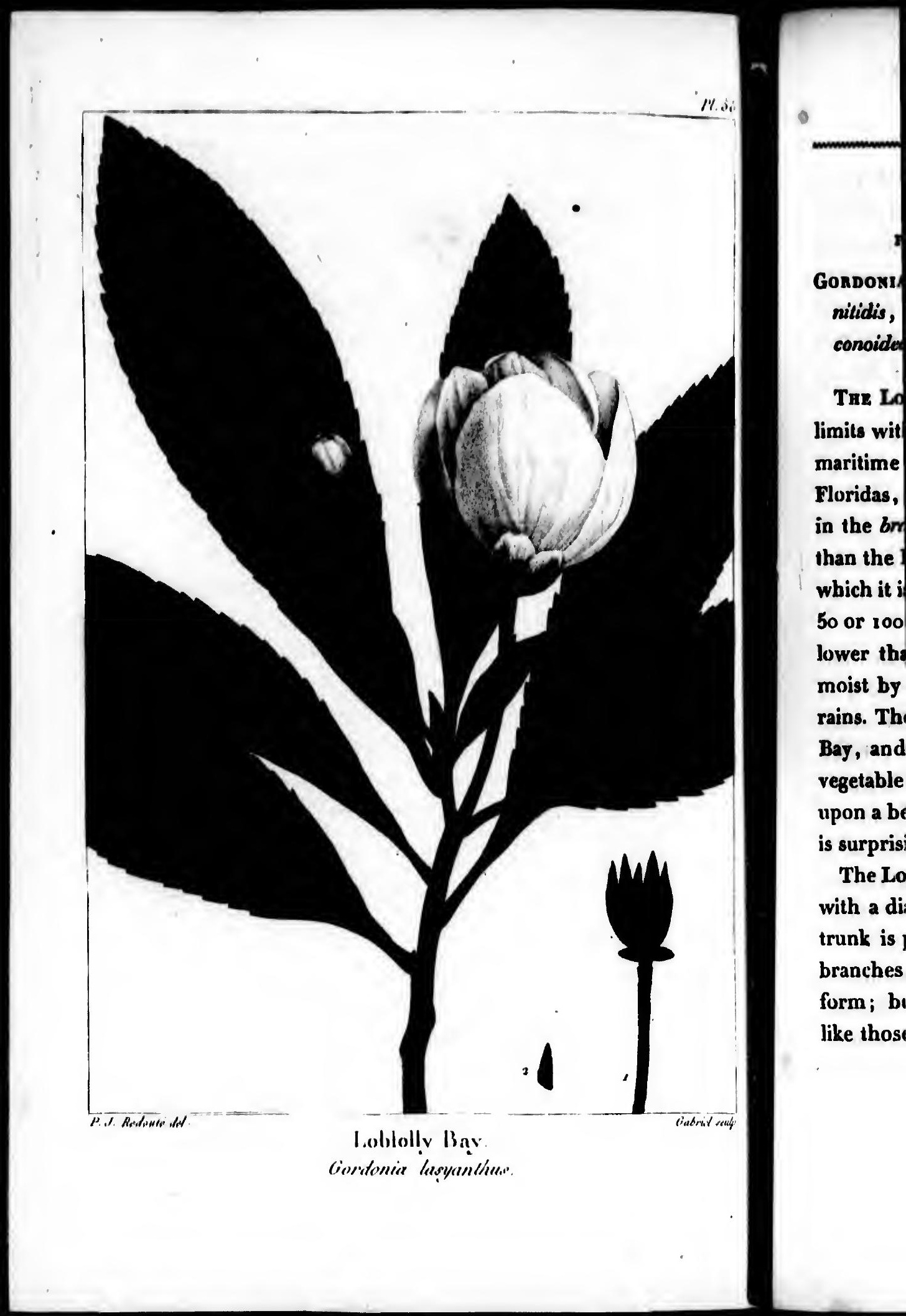




\section{LOBLOLLY BAY.}

Polyandria Monogyaic. Liy:

Malveen Jow.

Gondonia rasyantmus. G. folits glabernimis, subserratis, nilidis, coriaceis; Moribus longè pedunculatis; capsuld conoided, acuminatd.

Tre Loblolly Bay is comprehended within the same limils with the Long-leaved Pine, being contined to the maritime parts of the Southern States, to the two Floridas, and to Lower Louisiana. It is very abundant in the branch swamps, and exists in greater proportion than the Red Bay, Swamp Bay and Black Gum, with which it is usually associated. In the pire barrens, tracts of 50 or 100 acres are met with at intervals, which, being lower than the adjacent ground, are kept cunstantly moist by the waters collected in them after the great rains. These spots are entirely covered with the Loblolly Bay, and are called Bay Swamps. Although the layer of vegetable mould is only 3 or 4 inches thick, and reposes upon a bed of barren sand, the vegetation of these trees is surprisingly luxuriant.

The Loblolly Bay grows to the height of 50 or 60 feet, with a diameter of 18 or 20 inches. For 25 to 30 feet its trunk is perfectly straight. The small divergency of its branches near the trunk gives it a regularly pyramidical form; but as they ascend they spread more loosely, like those of other trees of the forest. 
The leaves are ever-green, from 3 to 6 inches long, alternate, oval-acnminate, alightly toothed, and smooth and shining on the upper-surface. The flowers are more than an inch broad, white and sweet-scented; they begin to appear about the middle of July and bloom in succession during 2 or 3 months. This tree possesses the agreeable singularity of bearing flowers. when it is only 3 or 4 feet high.

The fruit is an oval capsule, divided into five compartments, each of which contains small, black, winged seeds. These seeds appear to germinate successfully only in places covered with Sphagnum, a species of moss which copiously imbibes water, and in which are found thousands of the joung plants, which are plucked up with ease.

The bark of the Ioblolly Bay is very smooth while the tree is less than 6 inches in diameter; on old trees it is thick and deeply furrowed. In trunks which exceed $\mathbf{1 5}$ inches in diameter four fifths of the wood is heart. The wood is of a rosy hue, and of a fine, silky texture : it appears to be very proper for the inside of furniture, though the Cypress is generally preferred. It is extremely light; when seasoned it is very brittle, and it rapidly decays unless it is kept perfectly dry : hence it is entirely neglected in use, and is not employed even for fuel.

The value of the Loblolly bark in tanning compensates. in some measure for the uselessness of its wood: it is employed for this purpose throughout the maritime 
tes long, smooth vers are scented; July and This tree flowers

ve comblack, successa species in which hich are

th while old trees $h$ exceed is heart. texture : rniture, tremely rapidly entirely uel. ompenwood : aritime

parts of the Southern States and of the Floridas. For although this branch of industry is by no means as extensively practised in this part of the country as in the Northern States, and though these regions afford many species of Oak, yet the species whose bark is proper for tanning are not sufficiently multiplied to supply the consumption. As much of the bark of the Spanish Oak as can be obtained, of which the price is one half greater, is mixed with that of the Loblolly Bay. This tree has the advantage of maintaining very long the circulation of its sap, so that the bark may be taken off during three or four months.

I can add little to this description of the Loblolly Bay : the luxuriance of its vegetation, the beauty of its flowers; and the richness of its ever-green foliage place it among the Magnolias, and, with the other species, it contributes to the ornament of the forests in the southern part of the United States. It is less sensible to cold than the Big Laurel, and with some attention it may be brought through the winter in the climates of Paris and London. 'This opinion is corroborated by the fact that I have seen several of these trees growing in the Botanical Garden, founded by Dr. D. Hosack, near New York, where no other precaution was used than slightly covering them in the winter.

\section{PLATE LVIII:}

$A$ branch, with leaves and a flower of the natural size. Fig. I, A seed vessel. Fig. 2, $A$ serd. 


\section{FRANKLINIA.}

Gondonin pubescens. G. foliis lanceolatis, subserratis, subpubescentıbus; floribus subsessilibus, capsuld sphaerica.

This species of Gordonia appears to be restricted by nature within very narrow bounds, having hitherto been found only on the banks of the Altamaha in the State of Georgia. It was discovered there in $177^{\circ}$ by John Bartram, who gave it the name of Franklinia in honour of one of the most illustrious founders of American independence: a philosopher equally distinguished by his scientific acquirements and by his patriotic virtues.

The Franklinia is much smaller than the preceding species, and rarely exceeds 3o feet in height and 6 or 8 inches in diameter. The bark of the trunk presents a smooth and angular surface, like that of the Hornbeam. The leaves are alternate, oblong, narrowed at the base and toothed : they are annually shed in the fall.

The Franklinia blooms in Carolina about the beginning of July, and a month later near Philadelphia. The flowers are more than an inch in diameter, white and of an agreeable odo:ar. Like those of the Loblolly Bay, they open in succession during two or three months, and begin to appear when the trec is only 3 or 4 feet high.

The fruil is in the form of round, ligncous capsules, 
which, to releas Altho: degrees to be fa trees of about 4 luxurian uninjure of Penn The F England less kind to be les easily be cially wl to the de

1. bra Fig. I, seed. 
which, when ripe, open at the summit in four seams, to release the small, angular seeds.

Although the Franklinia is only found two or three degrees farther south than the Loblolly Bay, it appears to be far less sensible to cold; for I have seen several trees of this species in the garden of $J$. and W. Bartram, about 4 miles from Philadelphia, whose growth was luxuriant, and which, during 25 years, had remained uninjured by the severe winters which congeal this part of Pennsylvania.

The Franklinia has long been cultivated in France and England; but though the cold is less intense, it grows less kindly at Paris than at Philadelphia. This tree seems to be less highly esteemed than it deserves : it might easily be naturalised, and its magnificent flowers, especially when rendered double; would richly contribute to the decoration of our pleasure grounds.

\section{PLATE LIX.}

1. branch with lenpes and a flower of the natural sire: Fig.1, The copnle which contains the seeds. Fig. 2, A seed. 


\section{PAPAW.}

Polyandria polvitaia. LuW.

Snomer Juen.

Anona tRILobi. A. foliis glabriusculis, oblongècuneatoobovalibus; petalis exterioribus arbiculatis; fructibus maximis, crussius coumosis.

Althougin the Papaw must rrequently presents itself in the form of a shrub, it sometimes exhibits such dimensions that it may be ranked among trees of the third order; as it is sufficiently intereating in other respects to merit attention i lave, therefore, thought proper to describe it.

By the French of Upper Louisiana and of the two Canadas, the Anona triloba is called Assiminier, and by the Americans, Papaw. I have not olsserved it north of the Schuykill river, and it appears to be unknown, or extremely rare, in the luw and maritime parts of the Southern States. It is nut uncommon in the bottoms which stretch along the rivers of the Middle States; but it is most abundant in the vich vallies intersected by the western waters, where, at intervals, it forms thickets exclusively occupying several acres. In Kentucky and in the western part of 'Tennessec, it is sometimes seen also in forests where the soil is luxuriantly fertile; of which its presence is an infallible proof. In these fore: is it at:

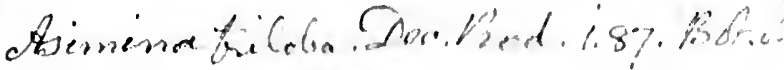

$$
\begin{aligned}
& \text { t.58sh. }
\end{aligned}
$$




$$
\text { 清 }
$$


unins: the inches * vation:

The le nate, $5 \mathrm{c}$ widening fine text brilliant. peduncle When the begir an inch an oval fo pulp is $s$ veral larg the mark ren. At making fr ing this tained of The tr bark, wh is spongy applicable ticed that ticularly 1 seous odr long resp 
twithe the height of 3 . feet and the diametex of 6 or 8 inches, though it generally stops chort of half this elevation.

The leaves are borne on short petioles, and are alternate, 5 or 6 inches in length, and of an elongated form, widening from the base ta the summit. They are of a fine textnre, and the superior surface is smopth and brilliant. The flowers, which are attached by short peduncles, are pendent and of a purple hue.

When the fruit is ripe, which takes place towards the beginning of Augnst, it is about 3 inches long and an inch and a half thick, of a yellowish colour, and of an oval form, irregular and swelling into inequalites. Its pulp is soft and of an insipiditaste, and it contains several large, triangular stones. It is never brought into the markets, and is sought in the woods only by children. At Pittsburgh some persons have succeeded in making from it a spirituous liquor; but, notwithstanding this experiment, very feeble hopes can be entertained of cultivating the tree with protit for this purpose.

The trunk of the Papaw is covered with a silver-grey bark, which is smooth and even polished. The wood is spongy, extremely soft, destitute of strength, and applicable to no use in the mechanical arts. I have noticed that the cellular integument of the bark, and particularly that of the roots, exhales in summer a nauseous odour, so strong as to occasion sickness if it is long respired in confined air. 
302

PAPA W:

This tree has bloomed in Europe for many years; but it rarely fructities, and is principally esteemed for the beauty of its flowers and of its foliage.

PLATE IX.

A branch with leaves and foovers of the natural sice: Fo. 1 , Thini of the natural size and colour. Fig. 2, A stone sepanated from the pulp.

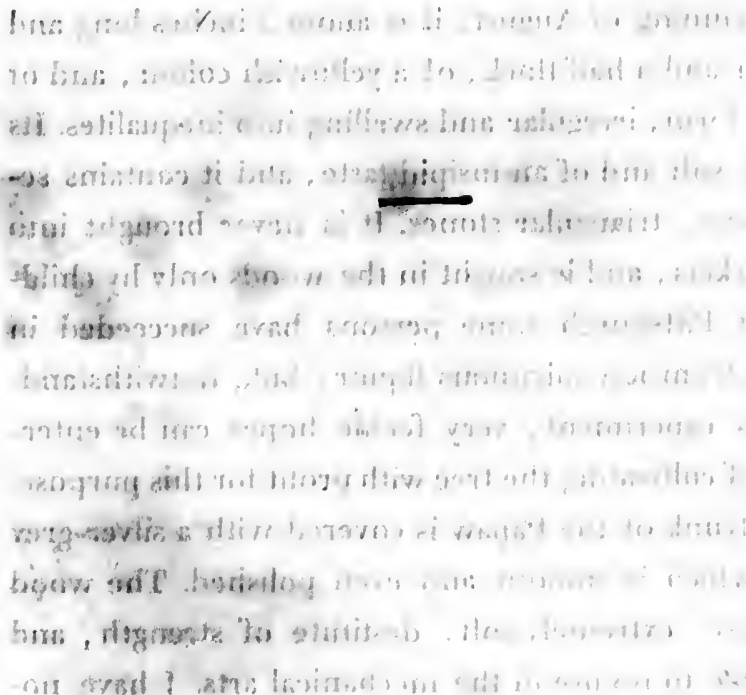





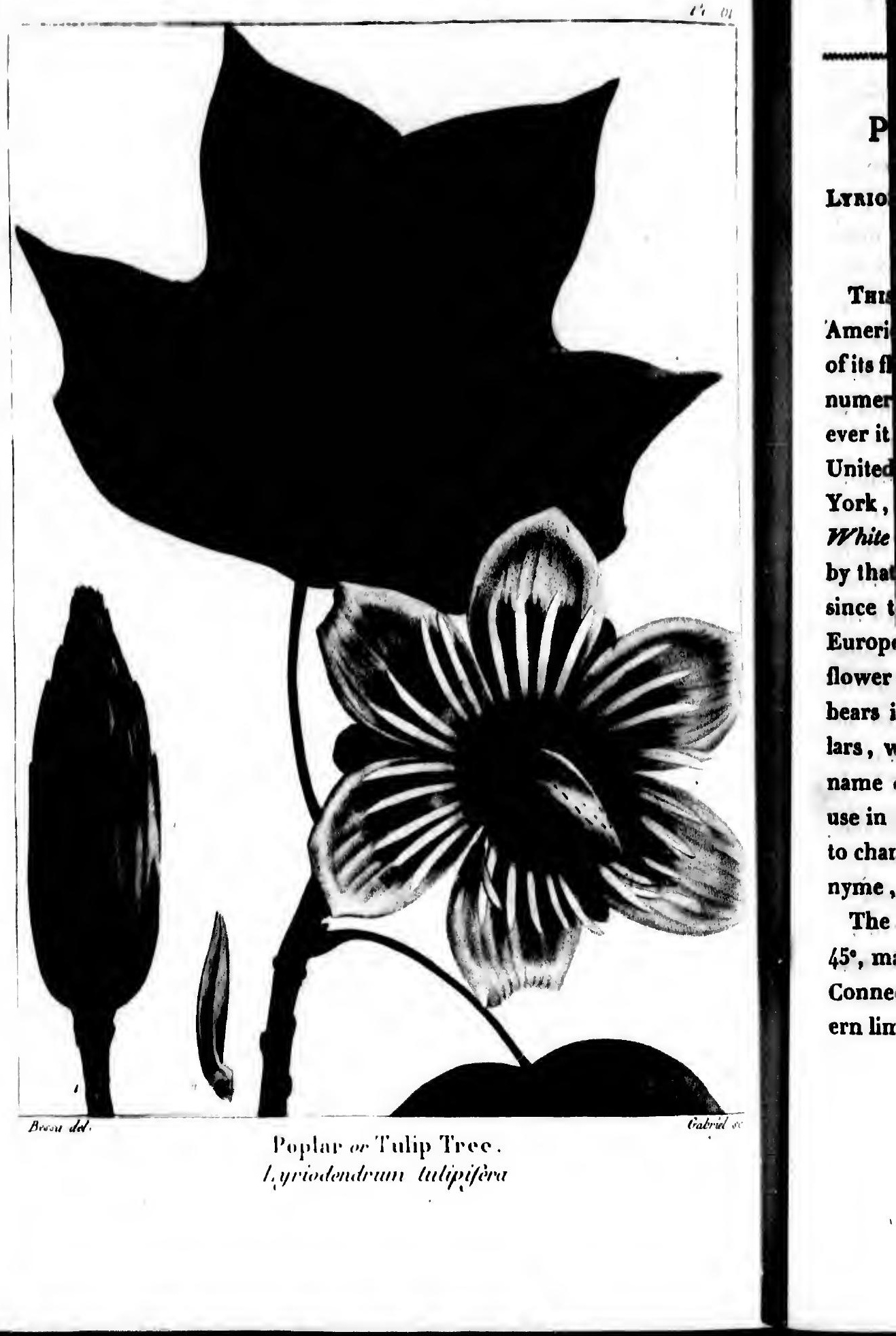




\section{POPLAR, OR TULIP TREE.}

Lrasodendaum muxupiman. L. foliis trilobis; lobo medio inuncato; calice triphyllo.

Tars tree; which surpasses most others of North America in height and in the beauty of its foliage and of its flowers, is also one of the most interesting from the numerous and useful applications of its wood. Wherever it abounds, and throughout the greater part of the United States, it is called Poplar. In Connecticut, New York, and New Jersey, it is known by the name of White Wood and of Canoe Wood, and more rarely, by that of Tulip Tree. This last denomination, which, since the introduction of the tree, has been adopted in Europe, is certainly the most proper, because the Hower nearly resembles the tulip, and because the tree bears in none of its characters any analogy to the Poplars, which are in every respect inferior to it. But the name of Poplar has become so generally sanctioned by use in the United States, that I have not felt at liberty to change it, and have only annexed the other as a synonyme, with a feeble hope of its ultimately prevailing.

The southern extremity of Lake Champlain, in latitude $45^{\circ}$, may be considered as the northern limit, and the Connecticut river, in the longitude of $7^{\circ}$, as the eastern limit of the Tulip Tree. It is only beyond the Hud- 
son, which flows two degrees farther west, and below the $43^{\circ}$ of latitude, that it is frequently met with and fully developed. Its expansion is not here repressed, as in Vermont and in the uppor part of Connecticut, by the excessive cold, and by a mountainous surface unfavourable to its growth. It is multiplied in the Middle States, in the upper parts of the Carolinas and of Georgia, and still more abundantly in the western country, particularly in "Kentucky. "Its' comparative rareness in the maritime parts of the Carolinas and of Georgia, in the Floridas and in Tower Lotiosiana, is owing less to the heat of the summer than to the nature of the soil; which in some parts is too dry, as in the pirie-barrens, ahd in others too wet, as in the swamps which border the rivers. Even in the Middle and Western States, the Tulip Tree is less abundant than the Oals, the Walnuts, the Ashes and the Beeches, because it delights only in deep, loamy, and extremely fertile soils, such as are found in the rich bottomis that lie along the rivers, and on the borders of the great swamps. that are enclosed in the forests.

In the Atlantic States, especially at a considerable. distance from the sea, Tulip Trees are often seen 70 , 80, and 100 feet in height; with a dianieter from 18 inches to 3 feet. But the Western States appear to be the natural soil of this maginificent tree", and here it displays its most powerful regetation. 'It is commonly found mingled, with other trees, such as the Hickories, in circe from 1 have si trees o Tree, mensio diamete regular ness of Button the mo In th from compo: which, the $\mathrm{mi}$ they tir scales, 
POPLAR, OR TULIP TREE.

the Black Walnut and Butternut, the Coffee Tree and the Wild Cherry: Tree : but it sometimes constitutes alone pretty lange tracts of the fonest, as my father observed in Kentucky, on the road from Beard Stone to Louisville. In, no other part of the United States did he find Tulip Trees solofty, and of so great a diameter. He observed many, of them in passing which appeared to be 15 or 16 feet in circumference; and; three miles and a half from Louisville, he measured one; which at 5 feet from the ground was 22 feet and 6 inches in circumterence, and whose elevation he judged to be from 120 to 140 feet : the correctness of this estimate I have since had an opportunity of proving. Of all the trees of North America with deciduous leaves, the Tulip Tree, next to the Buttonwood, attains the amplest dimensions ; while the perfect straightness and uniform diameter of its trunk for upwards of 40 feet, the more regular disposition of its branches, and the greater richness of its foliage, give it a decided superiority over the Buttonwood, and entitle it to be considered as one of the most magnificent vegetables of the temperate zones.

In the developement of its leaves, the Poplar differs from most other trees. Leaf-buds, in general, are composed of scales closely applied one upon another, which, in the spring, are distended by the growth of the minute bundle of leaves which they enclose, till they tinally fall. On some trees, these buds are without scales, as for instance on the Butternut. On the Tulip 
Tree, the terminal bud of each shoot swells considerably before it gives birth to the leaf : it forms an oval sack which contains the young leaf, and which produces it to the light only when it appears to have acquired sufficient force to endure the influences of the atmosphere. Within this sack is found another, which, after the first leaf is put forth, swells, bursts; and gives birth to a second. On young and vigorons trees, five or six leaves issue successively in this manner from one sack. Till the leaf has acquired half its growth, it retains the two lobes which composed its sack, and which are now called stipulce.

In the spring, when the weather is warm and humid, the growth of the leaves is very rapid : they are 6 or 8 inches broad, borne on long petioles, alternate, somewhat fleshy, smooth, and of a pleasing green colour. They are divided into three lobes, of which the middle one is horizontally notched at its summit, and the two lower ones are rounded at the base. This conformation is peculiar to the Tulip Tree, and renders it easily distinguishable in the summer. 1 lowers, which are large, brilliant, and on detached trees very numerous, are variegated with different colours, among which yellow predominates : they have an agreeable odour, and, surrounded by.luxuriant foliage, they produce a fine effect. In the spring they are gathered by women and children in the neighbourhood of New York, and sold in the market of that city. tree.

The h approacl is white it is muc fine and and pol for uses separate resists $t$ attacked in wide it is liah dryness 
nsider-

in' oval oduces qquired atmos, after d gives five or im one retains ich are

humid, e 6 or 8 , somecolour. middle the two rmation distine large , us, are yèllow d, sure effect. hildren $d$ in the

The fruit is composed of a great number of thin, narrow scales, attached to a common axis, and forming a cone 2 or 3 inches in length. Each cone corsists of 60 or 70 seeds, of which never more than a third, and some seasons not more than seven or eight in the whole number, are productive. It is also observed that during ten years after it begins to yield fruit, almost all the seeds of the Tulip Tree are unproductive, and that, on large trees, the seeds from the highest branches are the best.

The bark, till the trunk exceeds 7 or 8 inches in diameter, is smooth and even : it afterwards begins to crack, and the depth of the furrow and the thickness of the bark are proportioned to the size and to the age of the tree.

The heart or perfect wood of the Tulip Tree is yellow, approaching to a lemon colour, and its sap or alburnum is white. Though this tree is classed as a light wood; it is much heavier than the Poplars; its grain is equally fine and more compact, and the wood is easily wrought and polishes well. It is found strong and stiff enough for uses that require great solidity. The heart, when separated from the sap and perfectly seasoned, long resists the influence of the air, and is said to be rarely attacked by worms. Its greatest defect, when employed in wide boards and exposed to the weather, is that it is liable to shrink and warp by the alternations of dryness and moisture : but this defect is in a great mea- 
sure compensated by its other properties. The nature of the soil has so striking an influence upon the colour and upon the quality of the Tulip wood, that the mechanics who employ it have made the remark, and have distinguished it by the names of White Poplar and Yellow Poplar. The external appearances which mark these viarieties are so equivocal, that it can be ascertained to which a tree belongs only by cutting it. It is known in general that the White Poplar grows in dry ; gravelly, and elevated places; it is recognised too by its branchy summit, and by the small proportion which the light yellow heart bears to the sap. The grain also is coarser and harder; and the wood decays more speedily; hence it is always neglected when the other variety can be obtained. The Yellow Poplar possesses every quality requisite to fit it for so great a variety of uses, that I shall content myself with mentioning the most common. At New York and Philadelphia, and in the adjacent country, the Poplar is often employed, in the construction of houses, for rafters and for the joists of the upper stories, for which purposes it is esteemed on account of its lightness and strength. In the other Middle States, in the upper parts of the Carolinas, and above all in the Western States, it is more generally used in building, and is considered as the best substitute for the Pine, the Red Cedar and the Cypress. Wherever it abounds it serves for the interior work of houses, and sometimes for the exterior covering, as I 
POPEA I, OR TURIP TREE:

5og

observed in several small towns situated between Laurel Hill and the Monongahela river. It is not easy in this region to: procure pine boards, which otherwise would be preferred, as they do not, like those of Poplar, warp when expesed to the weather. The pannels of doors and of wainscots, and the mouldings of chimney-pieces ane made of Poplar. In the States of Ohio and Kentucky, on the banks of the Miami river, and in the upper part of North Carolina, Poplar shingles about 15 inches long are preferred for covering roofs, because they are the most durable, and because they are not liable to split by the effect either of intense frost or af ardent sunshine:.

In all the large towns of the United States; 'Tulip.Tree or Poplar boards, which are often 2 or 3 feet wide, are exclusively used for the pannels of coaches and chaises. When perfectly dry, they receive paint well., and admit of a.brilliant polish: The vicinity of Boston does not produce this tree, and the coach-makers procure it from New York and Philadelphia : it is also sent for the same use to Charleston, S. C., where the Tulip Trees are few in number and inferior in size. The seat of windsor chairs, which are fabricated at. New York, Philadelphia and Baltimore, and in many other towns, is always of Poplar : a larger quantity of the wood than would be supposed is consumed in this way, and also in the manufacture of trunks which are covered with skins, 
and of bed-steads which are ofained in imitation of mahogany. I have remarked that the circular board and the wings of fanning-millo are of thio wood; as it is easily wrought in the lathe, and is very light, it is much used for wooden bowls : it is also preferred for the head of hair brooms or sweeping brushed. The farmers choose it for the eating and drinking troughs of cattle : these troughs are formed of a single piece, and exposed to the weather they last as long as those made of Chesnut and of Butternut. In Kentucky I haveseen the Tulip Tree employed for the rails of rural fence; but I must confess my inattention in not learning their duration. It is found useful also in the construction of wooden bridges, as it unites lightness with strength ind durability. I have been assured that the heart of the Poplar might be profitably employed for the fellies of large mill-wheels: The Indians who inhabited the Middle States, and those who still remain in the western country, preferred this tree for their canoes, which, consisting of a single trunk, are very light and strong, and sometimes carry twenty persons. In fine, the Poplar affords excellent charcoal, which is "employed by smiths in districts that furnish no fossile coal. In the lumbenyards of New York, Philadelphia and Baltimore, a great quantity of this wood is found in forms convenient for the uses which I have eaumerated. It is very cheap, being sold at half the price of Black Walnut, Wild Cherry and Curled Maple. 
In all the country watered by the river Monongahela, betweer the $39^{\circ}$ and $40^{\circ}$ of latitude, the Tulip. Tree is 80 abundant, that large ratts, composed wholly of these logs ; are made to float down its stream. At Brownsville they are genyn into boards, which are used in the environs.' and even wr pittsburgh, in the construction of houses; and which are sold at 10 dollars for 1,000 feet. I observed that the mean diameter of the logs was from 12 to 15 inches; that of the largest was from 20 to 24 inches, and that of the smallest 9 or 10 inches : their two extremities were of a dark blue colour. I have also remarked that when a Poplar is felled, the chips of the heart which are left upon the ground, particularly those which are half buried in the leaves, suffer at the end of three or four weeks a remarkable change; the lower part becomes of a deep blue, and they exhale a fetid; ammoniacal odour.

- The live par', or cellular integument of the bark which covers the trunk of the Tulip Tree, the bark of the branches, and still more that of the roots, has an agreeable smell and a very bitter taste. In Virginia, some inhabitants of the country steep the bark of these roots, with an equal portion of Dogwood bark, in brandy during eight days : two glasses of this tincture, taken every day, sometimes cure intermittent fevers. Poplar bark, reduced to powder and given in substance to horses, appears to be a pretty certain remedy for worms. 
i. The American . Museums fon December; 1792 , contains circumotantial detuils concerning the valivable propexties ascuibed to this berk by Dr, Young of Philadelphia I oball recall what he has written on this subject, though these, properties, have siace been denind by other physicians, in the United States, and thougum use use of this bark is not general in the country, and is unknown in the capituls, where the faculty, are most enlightened. In Dr, Yaung's.opinion, the most proper timeito gather the Poplar bark for medical use is the month of January: He, asserts that it is more bitter. than the Peruvian. barky, thqugh leas astringent, and that it possesses some properties in common with,the aeridaromatics; whence he concludes that it is a powerful tonic and antiseptic : the aromatic principle appears to reside in aresinous part of its substance, which stimulates the intestinal canal, and which operates as a gentle cathartic. In viany instances the stomach cannot support it, unless each dose is accompenied by a few drope of laudanum. In intermittent fevers, when taken after the biliary ducts have been evacuated by an emetic, it is often tound equal to. the Peruvian bark. In remitting fevers it is used with as. great success as in intermitting fevers, and in one instance it was found to operate more successfully than the Peruvian bark. In inflammatory disorders, where the phlogistic diathesis is not very strongly marked, and where a weakness of arterial action has taken place, it gives tone and vigour to the stomach. United with

laudanu:

sympton with nig catarrh the best bark. Dr whole $m$ remedy roots co that tak uated, it it is an aqueous of decoc substanci two drac

In Par bark of 1 quantity

The T ago, and high, ex are ann which $y$ spread w where it trunk, 1 and by $t$ 
Laudanum, it has frequently dissipated the alarming symptoms of pulmonary consurpption when attehded with nightly sweats and diarthea: 1 person afflicted with catarrh complicated with dyspepsia, which had resisted the best elmen remedies, was perfectly cured by this bark. Dr. ung also assures us that there is not in the whole muteria medica a more certain and eflicacious remedy in hysterical affections than the bark of Poplar roots combined with a small quantity of laudanum; that taken after the first passages have been evacuated, it is a specific in cholera infantium; in fime, that it is an excellent remedy for worms. It is given in aqueous extract, either in the form of infusion or of decoction, but it is most efficacious when taken in substanice : the dose for an adult is from one scruple to two drachms.

In Paris, a spirituous liquor is made from the fresh bark of Poplar roots, with the addition of a sufficient quantity of sugar to render it agreeable to the taste.

The Tulip Tree was introduced into Europe 60 years ago, and many stocks of this species, more than 50 feet high, exist in France, Germany and England, which are annually covered with myriads of flowers, and which yield productive seeds. It has been so widely spread within 15 years, that there are few country seats where it it is not found; and, by the fine form of its trunk, by the richness and singularity of its foliage, and by the beauty of its flowers, it is eminently fitted to 




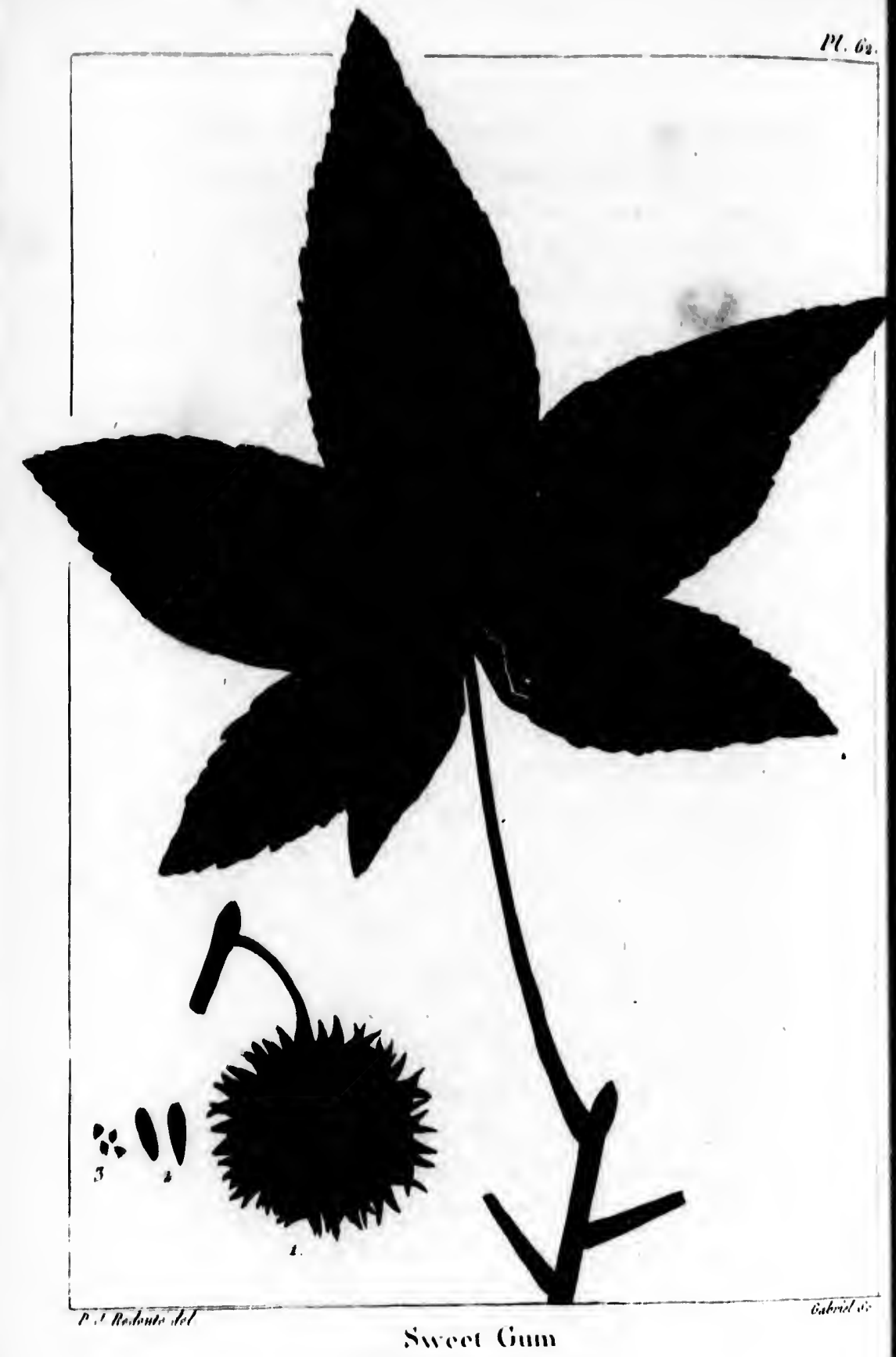
shor Ports it is $f$ from Illino of th with and a In Swee the I Gum the $n$ soil $i$ tions, Tupe and great owin 


\section{SWEET GUM.}

Monacia Polyandriu. Lınn.

Amentace. Jues.

Llquidary styraciflua. L. foliis palmatis, lobis acuminatis, dentatis; axillis nervorum villosis.

No tree has hitherto been found in North America so extensively diffused as the Sweet Gum. On the seashore it is first seen, towards the north-east, bet ween Portsmouth and Boston, in the latitude of $43^{\circ} 30^{\prime}$, and it is found as far as Old Mexico, towards the south-west : from the coast of Virginia it extends westward to the Illinois river, thus spreading over more than two thirds of the ancient territory of the United States, together with the two Floridas, Upper and Lower Louisiana, and a great part of New Spain.

In the United States this tree is universally called Sweet Gum, and by the French of Louisiana, Copalm. In the Middle, Western and Southern States, the Sweet Gum is sufficiently multiplied to be numbered among the most common trees : it is met with wherever the soil is fertile, cool and exposed to temporary inundations, and is usually seen in company with the Maple, the Tupelo, the Swamp White Oak, the Shagbark Hickory and the Butternut. In the South, it grows also in the great Swamps which border the rivers, and here, owing doublless to the mildness of the winter and to 
the intense heat of the summer, it disp/ys its amplest dimensions. The largest Sweet Gum that I have observed was in a swamp, 4 or 5 miles from Augusta in Georgia : at 5 feet from the ground it was 15 feet 7 inches in circumference; it ramified at the height of $15,18 \mathrm{feet}$, and its summit was spacious in proportion to the thickness of its trunk. The soil in which it grew was rich and constantly moist, and abounded particularly in the Chesnut White Oak, Willow Oak, Wahoo, Black Gum, Red Maple, Red Ash, and Black Ash.

From the form of a single tree it is not to be concluded that the Sweet Gum generally branches at so sinall an elevation. When confined amidst other trees, its trunk, like that of the Oak, the Elm and the Poplar, is perfectly straight and of an uniform size to the height of 30 or 40 feet, at which it begins to divide itself into branches : in these situations it is usually from 1 to 2 feet in diameter. As the Sweet Gum is profusely multiplied, it is often found on soils unpropitious to its growth. On dry and gravelly land its height does not exceed 15, 20 and 3o feet, and its secondary branches are covered with a dry and flaky bark, of which the plates are attached by the edge, instead of the face as on other trees.

The Sweet Gum is garnished with fine foliage, which changes to a dull red with the first autumnal frosts, and falls soon after. The shoots upon which the young leaves appear in the spring are smooth and of a yellowmated lated, particu the Sug they dif arly sh edge. It the lea rounde a visco these tr they ext The b branche conspic inch an ling wit an inch flexible are gree of a gre beginniı to the se pressed tains or 
SWETT GU M.

ish green col hr. The leaves vary in size from 3 to 6 inches, according to the vigour of the tree and to the situation of the leaf, being larger and less deeply palmated on the lower branches : they are alternate, petiolated, and divided into five principal lobes : in this last particular they bear some resemblance to the leaves of the Sugar Maple and of the Norway Maple, from which they differ in having the lobes deeper and more regularly shaped, and in being finely denticulated at the edge. It should be remarked also. that, at the birth of the leaves, the back part of the principal rib is surrounded by a small tuft of red down. In warm weather a viscous substance exudes from the leaves of such of these trees as grow upon dry grounds; when bruised, they exhale a sensible, aromatic odour.

The barren and fertile flowers are borne by different branches of the same tree. The fertile flowers are not conspicuous, and the barren ones are in oval aments an inch and a half in length. The fruit is globular and bristling with points : when arrived at maturity, it is about an inch and a half in diameter, and is suspended by a flexible pedicle, 1 or $a$ inches long : the globes, which are green at first and afterwards yellow, are composed of a great number of closely connected capsules. At the beginning of autumn these capsules open and give liberty to the seeds, which are small, blackish, oblong, compressed and surmounted by a wing. Each capsule contains one or two sceds united with a great number of

which frosts, young ellow-

anches as on

multi-

to its

es not (1) 
minute bodies incapable of germinati oaken saw dust.

The trunk of the full grown tree is covered with a deeply furrowed bark, not unlike that of several species of Oak. Sweet Gums are found of the same size and on the same soil, some of which have a large proportion of sap and only 5 or 6 inches of heart, while others onsist principally of perfect wood, with only a thin layer of sap. The heart is reddish, and when sawn into boards it is observed to be transversely marked at considerable distances with blackish belts. This wood is very compact and fine grained, and is susceptible of a bright polish. Though inferior in strength to the Oak, it suffices for many purposes which require great toughness and solidity. At Philadelphia, when perfectly seasoned and stript of the sap, it is used in building in the interior of houses, and especially for the joists of the upper stories : when employed with these precautions, it lasts longer than any species of Red Oak. As it furnishes boards of 2 or 3 feet in width, it is sometimes sawn very thin, and employed by cabinet makers to line the inside of certain articles of mahogany furniture : its lightness, the fineness of its grain, and its reddish complexion, render it peculiarly proper for this purpose.

In the country, furniture was formerly made of the Sweet Gum, which, when preserved with care, was not destitute of beauty, though inferior to the Black Walnut and the Wild Cherry wood, which are

harder, a: Gum is frames, less freo Curled N staircase: In a wor to the $B$ work tha caution i and, $\mathrm{mi}$ forms th

In sun sam tim a $x$ in,? small qua rolina, I in diame

All th: the woor that of of the $A$ composit ference $t$ Sweet Gı stocks.

In Eur open fiel 
harder, and l easily defaced: At Philadelphia the Sweet Gum is preferred for small, oval or round picture frames, which are died black; it serves also, though less frequently than the Wild Cherry Tree and the Curled Maple, for bedsteads and for the balusters of staircases. At New York it is commonly taken for coffins. In a word, the Sweet Gum, however inferior in quality to the Black Walnut, may be usefully employed in all work that is sheltered from the air, without which precaution it speedily decays. It is little esteemed for fuel, and, mixed with other species of no greater value, it forms the lowest quality of wood in the market.

In summer, upon cutting the live bark and at the sam. time slightly wounding the sap of the Sweet Gum, a 1 ins substance of an agreeable odour distils in small quantities : in repeated experiments made in Carolina, I was never able to collect from a tree of a foot in diameter more than half an ounce in a fortnight.

All that has been said of the properties and uses of the wood of the Sweet Gum, proves its inferiority to that of many other trees. Probably when the attention of the American proprietors becomes engaged in the composition of artificial forests, they will give the preference to other more useful species, reserving of the Sweet Gum only a small number of the most vigorous stocks.

In Europe, this tree has for many years grown in the open field; but, though it exceeds the height at which 
it fructifies in the United States, it has jet yielded seed , and for this reason it is not extensively multiplied. It deserves to be more generally diffused in parks and gardens; on account of the agreeable tint and singular form of its leaves:

\section{PLATE LVII.}

A branch, with a leaf of the natural size. Fig. I, Fruit of the natural size. Fig. 2, $A$ seed of the natural size. Fig. 3, Barren dust which accompanies the seed. 

P.63.

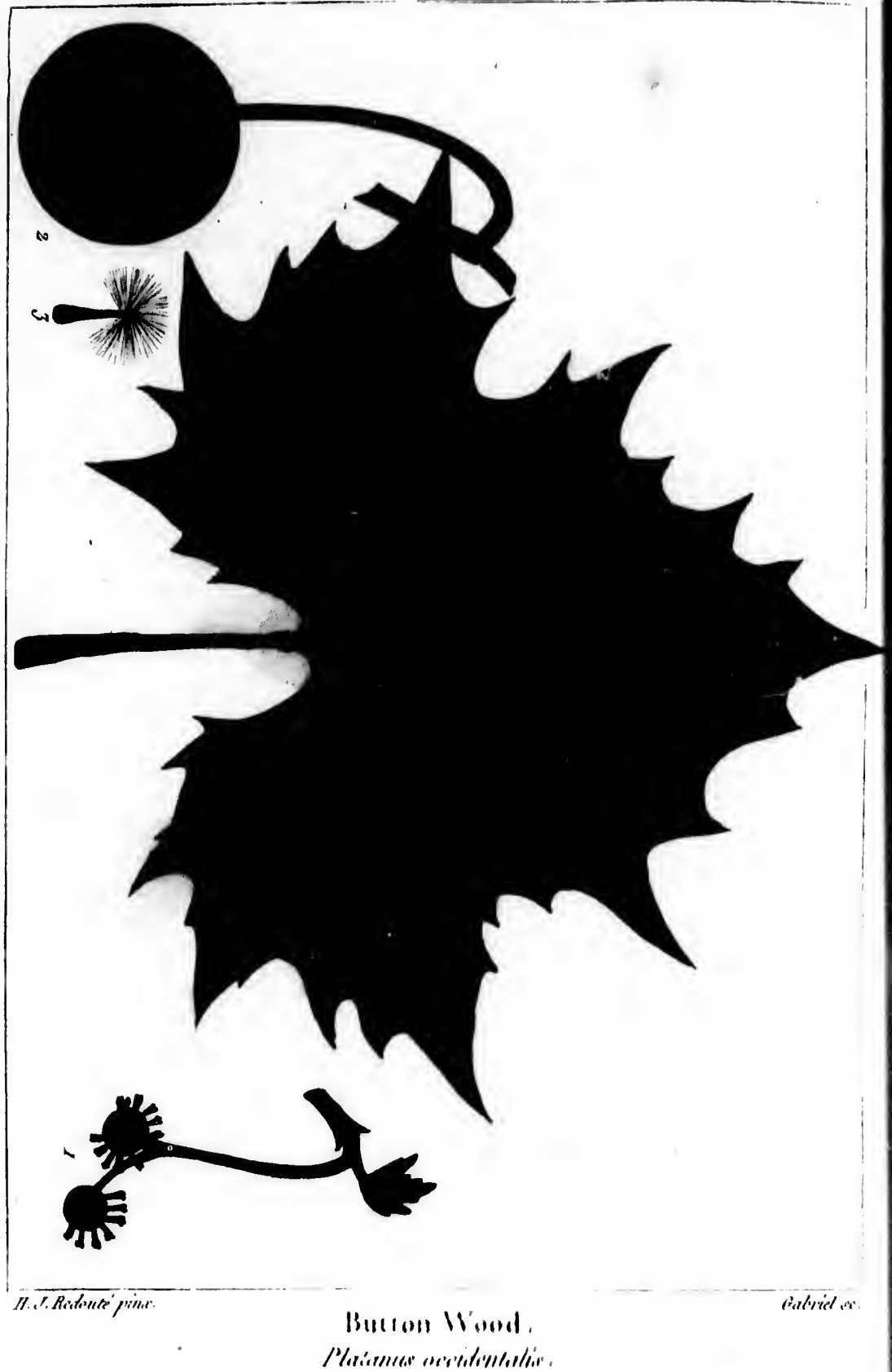
the $\mathbf{P l}$ dinary In $t$ by the nia, by and in freque Tree. give it minati not to others adopte that of Acce does $n$

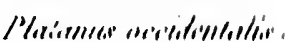




\section{BUTTONWOOD, on SYCAMORE.}

Monencia Monandria. Luxn. Amenteon. Jose.

Platanus occidentalis. P. foluis lobato-angulosis, ramulis albentibus.

Among trees with deciduous leaves, none in the temperate zones, either on the Old or the New Continent, equals the dimensions of the planes. The species which grows in the Western.World is not less remarkable for its amplitude and for $\mathrm{j}$ - magnificent appearance than the Plane of Asia, whose majestic form and extraordinary size were so mich celebrated by the ancients.

In the Atlantic States this tree is commonly known by the name of Buttonwood, and sometimes, in Virginia, by that of Water Beech. On the banks of the Ohio, and in the States of Kentucky and Tennessee, it is most frequently called Sycamore, and by some persons Plane Tree. The French of Canada and of Upper Louisiana give it the name of Cotton Tree. The inist of these denominations appears to be the most widely diffused, and not to be entirely unknown in those districts where the others are habitually employed; for this reason I have adopted it, though a less appropriate appellation than that of Plane Tree.

According to my ofn observations, the Buttonwood does not venture, towards the north-east, beyond Port- 
land, in the Jalitude of $40^{\circ} 30^{\prime}$; but farther west, in the $73^{\circ}$. of longitude, it is lound two degrees farther north, at the extremity of Lake Champlain and at Montreal. I have not observed it myself, in this direction, beyond Onion river in Vermont, and 1 have never seen it in the District of Maine, nor in Nova Scotia. The trees of this speries which exist at Halifax have been planted for ornament, and, though they are 40 feet in height, they do not display the same vigour as in a more southern latitude, where the winter is less rigorous. Proceeding from Boston and the shores of Lake Champlain towards the west and the south-west, the Buttonwood is continually met with over a vast tract, comprising the Atlantic and Western States, and extending beyond the Mississippi.

The nature of the Buttonwood confines it to moist and cool grounds, where the soil is loose, deep and fertile : the luxuriance of its vegetation depends upon the union of these circumstances. It is never found upon dry lands of an irregular surface among the White and Red Oaks and the Walnuts : it is also more rare in all the mountainous Iract of the Alleghanies than in the flat counfry. It is remarked in that part of Virginia which lies upon the road from Baltimore to Petersburgh, that, though the Buttonwood is multiplied in the swamps, its growth is stinted, and that it does not in general exceed 8 or 10 inch 8 in diameter. Farther south, in the lower parts of the Carolinas and of Georgia,

it is no is not which i pally co the Lob Buttony is, perh black an stantial this part excessive rica mo great riv the mor perhaps the Ohic the Grea Scioto, which ar forests, 'The soil unctuous by the sli nual ove autumn old trees into vege tile, a d 
it is not aburdant even on the sides of the rivers, and is not seen in the branch-swamps already mentioned; which intersect the pine-barrens, and which are principally covered with the Small Magnolia, the Red Bay, the Loblolly Bay, the Red Maple, etc. The cause of the Buttonword's not being found in these small marshes is, perhaps, that the layer of vegetable mould, which is black and always miry, is not sufficiently thick and substantial to support its growth, and that the heat, in this part of the Southern States, is long continued and excessive. The Buttonwood is in no part of North America more abundant and more vigorour ihan along the great rivers of Pennsylvania and of Virginia ; ive ugh, in the more fertile vallies of the West, its vegetation :s perhaps still more luxuriant, especially on the banks of the Ohio and of the rivers which empty into it, viz. the Great Muskingum, the Great Kenhaway, the Great Scioto, the Kentucky, the Wabash, etc. The bottongs which are watered by these rivers are covered with dark forests, composed of trees of an extraurdinary size. The soil is very deep; loose, of a brown colour, and unctuous to the touch : it appears to have been formed by the slime deposited in the course of ages, at the annual overflowing of the rivers. The leaves, which every autumn form a thick layer upon the surface, and the old trees that fall by the weight of years and crumble into vegetable mould, give to this soil, already so fertile, a degree of fecundity which is without example in 
524 BUTONWOOD, OR SYCAMORT.

Europe, and which is manifested by prodigies of vegetation.

The margin of the great rivers of the West is occupied by the Willow, after which comes the White Maple, and next the Buttonwood : but this arrangement is not uniformly observed, and the Maple alone, or, as it more frequently happens, mingled with the Buttonwood, sometimes grows upon the brink. Among the trees which compose these forests, these three species are least liable to injury from the continued presence of water, and by their position they are exposed to have their bases every year inundated by the swelling of the rivers. In these situations, the Buttonwood is constantly found to be the loftiest and largest tree of the United States. Often, with a trunk of several feet in diameter, it begius to ramify at the height of 60 or 70 feet, near the summit of the other trees; and often the base divides itself into several trunks equally vigorous and superior in diameter to all the surrounding trees.

On a little island in the Ohio, 15 miles above the mouth of the Muskingum, my father measured a Buttonwood which, at 5 feet from the ground, was 40 feet and 4 inches in circumference, and consequently more than 13 feet in diameter. Twenty years before, General Washinglon had measured the same tree, and found it to be of nearly the same size.

In 1802 , in a journey throngh the Western States, I found on the right bank of the Ohio, 36 miles from

Mariett: extraord myself found it still exh ramified equal si tonishin Plane T bollowe the Ron persons 75 feet resembl The $\mathrm{m}$ form an pears to that: hav species i richer fic Asiatic $\mathbf{p}$ nate, fro formed of the Ea face of th disappear this tree to the int 
Marietta, a Buttonwood whose base was swollen in an extraordinary manner : my travelling companion and myself measured it, and at 4 feet from the ground we found it to be 47 feet in circumference. This tree, which still exhibited the appearance of vigorous vegetation; ramilied at 20 feet from the ground. A Buttonwood of equal size is mentioned as existing in Genesec. The astonishing dimensions of these-trees recall the famous Plane Tree of Lycia spoken of by Pliny, whose trunk, hollowed by time, afforded a retreat for the night to the Roman Consul Licinius Mutianus, with eightcen persons of his retinue. The interior of this grotto was 75 feet in cireumference, and the summit of the tree resembled a small forest.

The most striking resemblance, in the majesty of their form and in the enormous size of their trunk, thus appears to exist between the only two species of Plane that have hitherto been discovered. The Amerigen species is generally thought, in Europe, to possess a wicher foliage, and to afford a deeper-shade than the Asiatic Plane : its. leaves are of a beautiful green. alternate, from 5 to 10 inches.broad, less deeply lobed, and formed with more open angles than those of the Plane of the Eastern Continent. In the spring, the lower surface of these leaves is covered with a thick down, which disappears towards summer. In certain districts where this tree is very abundant, its vicinity is a source of alarm to the inhabitants : they believe that the fine down from 
its leaves, floating in the air, produces an irritation of the lungs and a disposition to consumption. This apprebunaion I consider as a popular error; for the slightest zephyr suflices to waft to a distance, and to disperse in the uiry waste this light and impalpable substance.

The sexes are separate on the Buttonwood, but the male and female flowers are attached to the same peduncle, instead of being placed on different branches. I'he flowers are in the form of small balls : the fertile onces grow to the diameter of an inch, and are supported by pueduncles 2 or 3 inches long. These balls fall in the course of the winter and autumn, and, parting asunder, the sceds which compose them are scattered in the wind, by means of the plumy tuft by which they are surmounted.

'The trunk and branches of the Buttonwood are covercd with a sinooth, pale green bark, of which the epidermis detaches itself every year in portions : a sufticiently obvious character is thus afforded, by which to distinguish the tree when bared of its leaves. The roots when taken from the earth are of a beautiful red colour; but they loose this tint upon being split and exposed to the light in a dry place. The concentrical layers and the medullary rays are also observed to be much more distinct in the roots than in the body of the tree. In clearing new lands it is sometimes difficult to eradicate the Buttonwood : the stumps, during a long time, give birth to fresh shools, but, when once dead, they speedily decay.

these paralle that th directi and at to the

Cabi the Bu warpin to the harder is little colour

The atmosi shelter it may for joi into th and of times 
The Buttonwood, in seasoning, becomes of a dull red : its grain is line and close, and it is susceptible of a brighter polish than the wood of the Beesh, to which it bears some resemblance. Its concentrical circles are divided into numerous sections, by fine medullary rays extending from the centre to the circumference. When the trunk is sawn in a direction parallel to these rays, they appear larger than when it is cut parallel to the concentrical circles. It should trem then that the division should be rnade in an inturmediate direction, so that the spots may be of a proper size and at equal distances, which gives an elegant surface to the wood.

Cabinet-makers, at Philadelphia, rarely make use if the Buttonwood : they attribute to it the defect of easly warping, which does not belong to the Wild Cherry and to the Black Walnut. As these species of wood are also harder and of a more durable polish, the Buttonwond is little used except for bedsteads, which retain the colour of the wood and are coated with varnish.

The Buttonwood speedily decays when exposed to the atmosphere, hence it is proper only for work that is sheltered from the weather; when thorot $i$, ing seasoned, it may be usefully employed in the interior of houses for joists, and for sheathing the frantr. It never enters into the construction of vessels. 'I he French of Illinois and of Pust Vincennes, on the river Wabash, sometimes fashion it into canoes, one of which, made a few 
years since on this river, of a single Buttonwood, was 65 feet long, and carried 9,00o pounds.

It is difficult to mark the difference between the two species of Plane in the colour and organisation of their wood. If the excellencies which were ascribed by the ancients to the wood of the Plane are not recognised in that of the Buttonwood, it is perhaps owing to the great variety of timber proper for building, which is furnished by the soil of the United States, and to the superiority, in cabinet-making., of mahogany, which is obtained with facility from the West Indies.

The Asiatic and American Planes have been many years cultivated in Europe : the rapid growth and majestic appearance of these trees render them proper for adorning extensive parks and gardens, and for forming the avenues leading to large towns. In the United States, where the atmosphere is more humid than in Europe, they would perfectly fulfil this destination in all situations where the soil is not too dry. Their rich and shady foliage is tree from the incunvenience of being devoured by caterpillars, which in North America, still more than in Europe, infest the Elm and the Cherry Tree.

\section{PLATE LXIII.}

A leaf of a third of the natural size. Fig. I, Flowers: Fig. 2, Fruit at maturity. Fig. 3, $A$ seed. 
their the

d in great shed rity, ined

nany ma$r$ for ming ates, ope, ituahady ured than wers: 


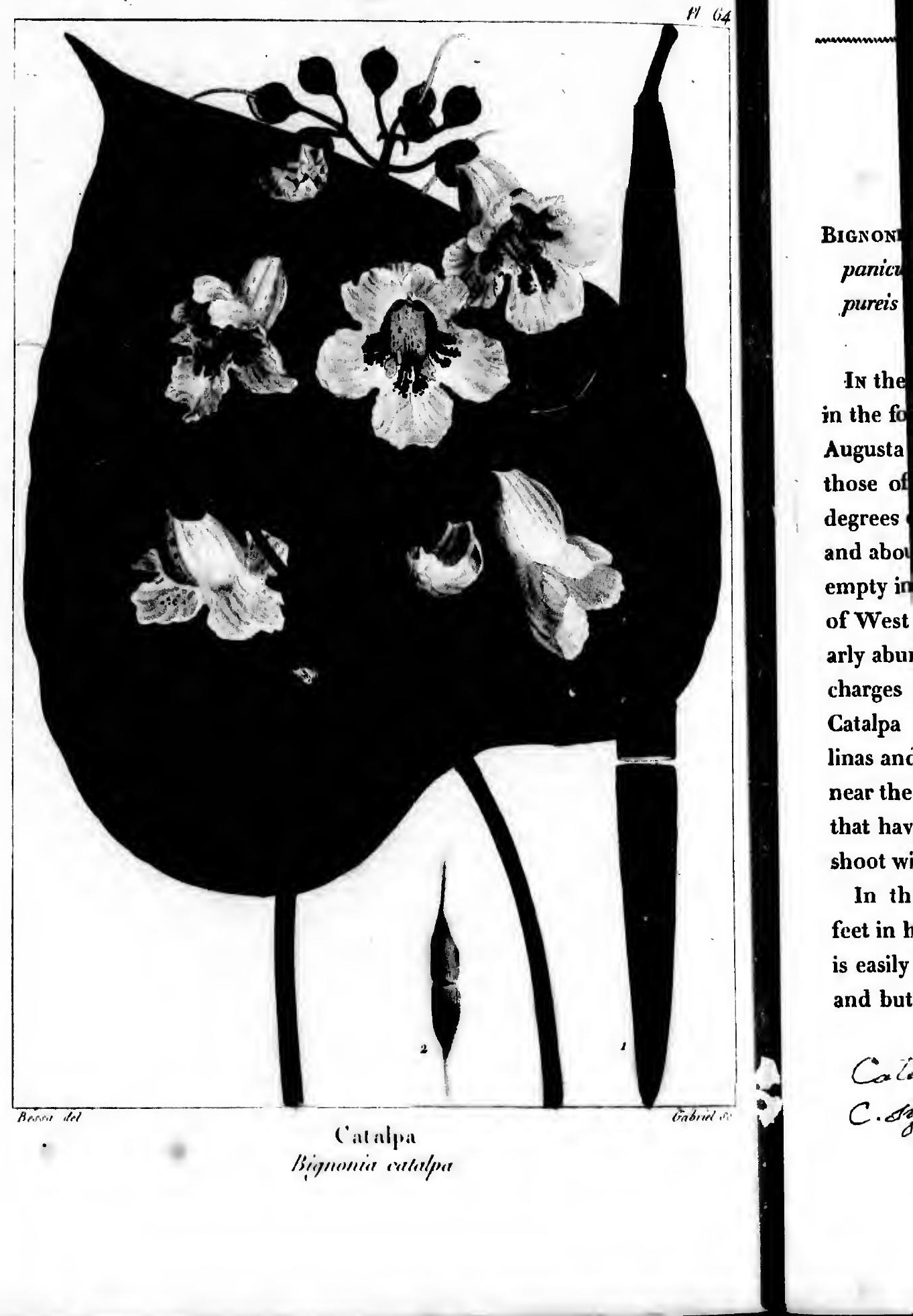




\section{CATA L PA.}

Didynamia Angiospermia. Lıк. Bignouiz. Juss.

Bignomia catalpa. B. foliis simplicibus, temis, cordatis; panicula laxissimâ; floribus diandris, intìs maculis purpureis et luteis aspersis; capsulâ gracili, longâ, tereti.

IN the Atlantic States, the Catalpa begins to be found in the forests on the banks of the river Savannah, near Augusta in Georgia, and west of the Alleghanies, on those of the Cumberland, between the 35th and 36th degrees of latitude. Farther south it is more common, and abounds near the borders of all the rivers which empty into the Mississippi, or which water the province of West Florida. I have been assured that it is particularly abundant on the Escambia or Conechu, which discharges itself at Pensacola. It is remarkable that the Catalpa should not exist in the lower part of the Carolinas and of Georgia, and in East Florida, which lie so near the country of its natural growth, and where stocks that have been planted for ornanuent about the houses shoot with extraordinary vigour.

In these southern regions it frequently exceeds 50 feet in height, with a diameter from 18 to 24 inches. It is easily recognized by its bark, which is of a silver-grey and but slightly furrowed, by its ample leaves, and by

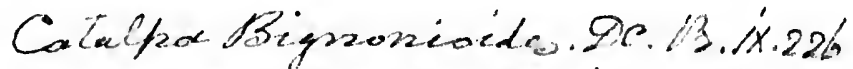

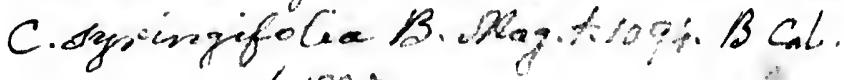

$$
\begin{aligned}
& t .128 s
\end{aligned}
$$


its wide spreading summit, disproportioned in size to the diameter of its trunk. It differs from other trees also by the fewness of its branches.

The leaves are heart-shaped, petiolated, often 6 or 7 inches in width, glabrous above and downy beneath, particularly on the principal ribs; they are late in venturing out in the spring, and are among the first to shrink at the approach of autumn. The flowers, which are collected in large bunches at the extremity of the branches, are white, with violet and yellow spots, and are beautiful and showy. The capsules are cylindrical and pendent, of a brown colour when ripe, 3 or 4 lines in diameter and 12 or 15 inches in length.

The seeds are thin, flat, and enveloped in a long, narrow, membraneous wing terminated by a hairy tuft. Each seed, with its wing, is about an inch long, and a line and a half broad.

That the Catalpa is a tree of rapid growth is proved by the distance of the annual concentrical circles. Its wood is of a greyish white colour, of a fine texture, very light, and very brilliant when polished. It resembles the Butternut wood, with this exception, that the Butternut wood is of a reddish hue, and is less durable when exposed to the weather. Posts of the Catalpa perfectly seasoned have been recently proved to be very lasting, by experiments made in the United States. Such is the information which I have been able to collect concerning the wood of this tree : I have never

visited abound In th the Cat odour College tonick, the Per serving mentio thor af I have flowers though honey a In th Catawb: that for trom w cured : Section a corru Louisia Shawan on the 1 English cultivate of Paris 
visited the thinly inhabited regions in which it abounds.

In the spring, if a bit of the cellular integument of the Catalpa bark is removed, a venomous and offensive odour is exhaled. In a thesis supported at the Medical College of Philadelphia, this bark is maintained to be tonick, stimulant, and more powerfully antiseptic than the Peruvian bark : but this thesis appears to be undeserving of the same confidence with the treatise, already. mentioned, concerning the Dogwood, in which the author affords proofs of sound and various information. I have been assured that the honey co-scted fiom the flowers of this tree is poisonous, and that its effects, though less alarming, are analogous to those of the honey of the Yellow Jasmine, Geselminum nitidum.

In the Carolinas and in Georgia the Catalpa is called Catawbaw Tree, after the name of an Indian tribe that formerly inhabited a large part of these States, and from whose territory the tree was probably first procured : the name of Catalpa, adopted in the Middle Section of the United States and in Europe, is perhaps a corruption of this original. The French of Upper Louisiana call it Bois Shavanon, from the Shavanon or Shawanee nation which once existed in West Tennessee, on the borders of the river of this name, called by the English the Cumberland. The Catalpa has long been cultivated with success in Europe, though in the climate of Paris its young shoots sometimes suffer by the late. 
frosts. Its rapid growth, the remarkable size of its leaves, and the beauty of its numerous bunches of flowers entitle the Catalpa to a distinguished place among ornamental trees; but it has ceased to be rare, and is less highly esteemed than while it was lass common.

PLATE LXIV.

$A$ leaf and a bunch of flowers of the natural size. Fig. $\mathrm{x}$, A vod. Fig. 2, $A$ seed. 


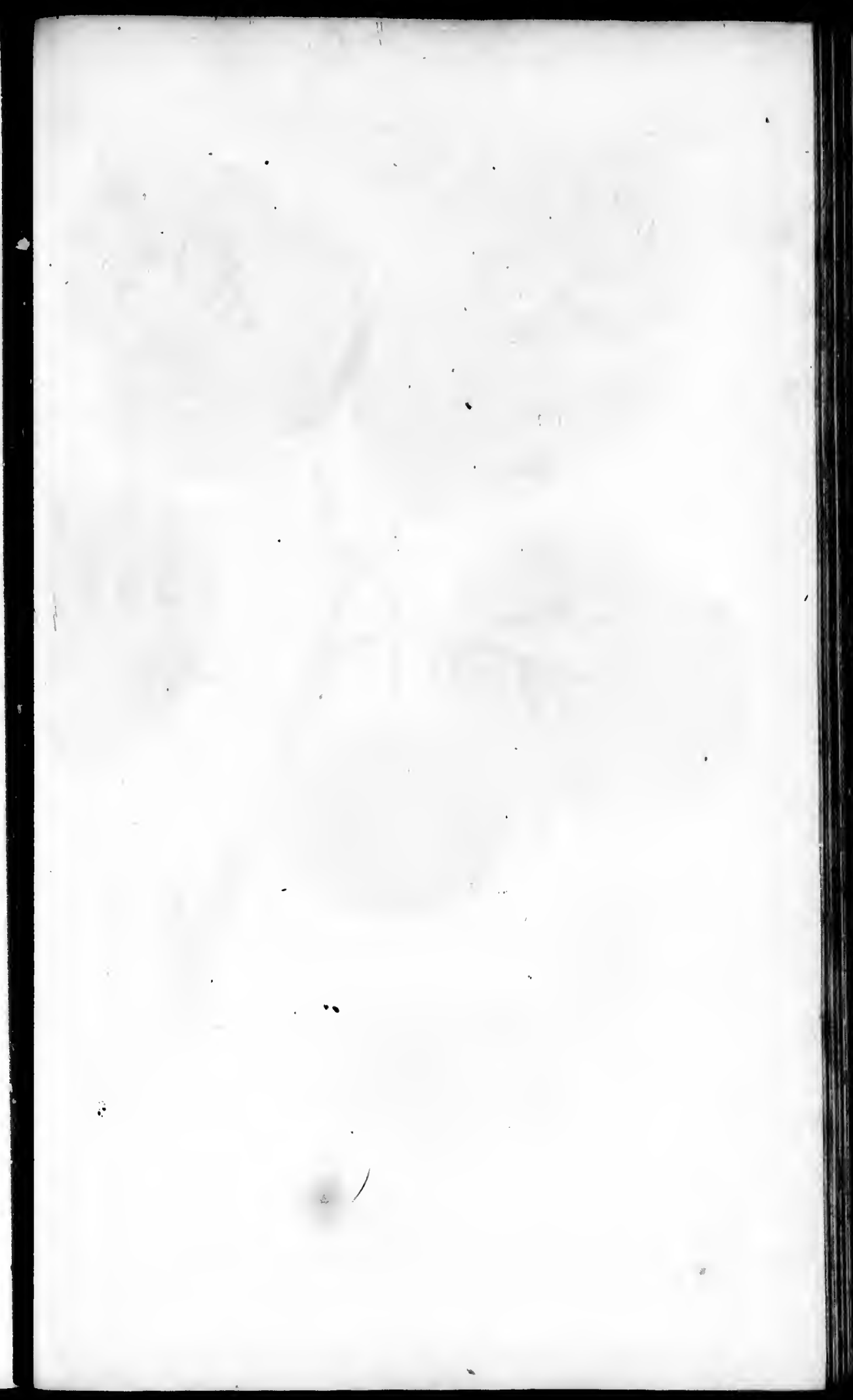




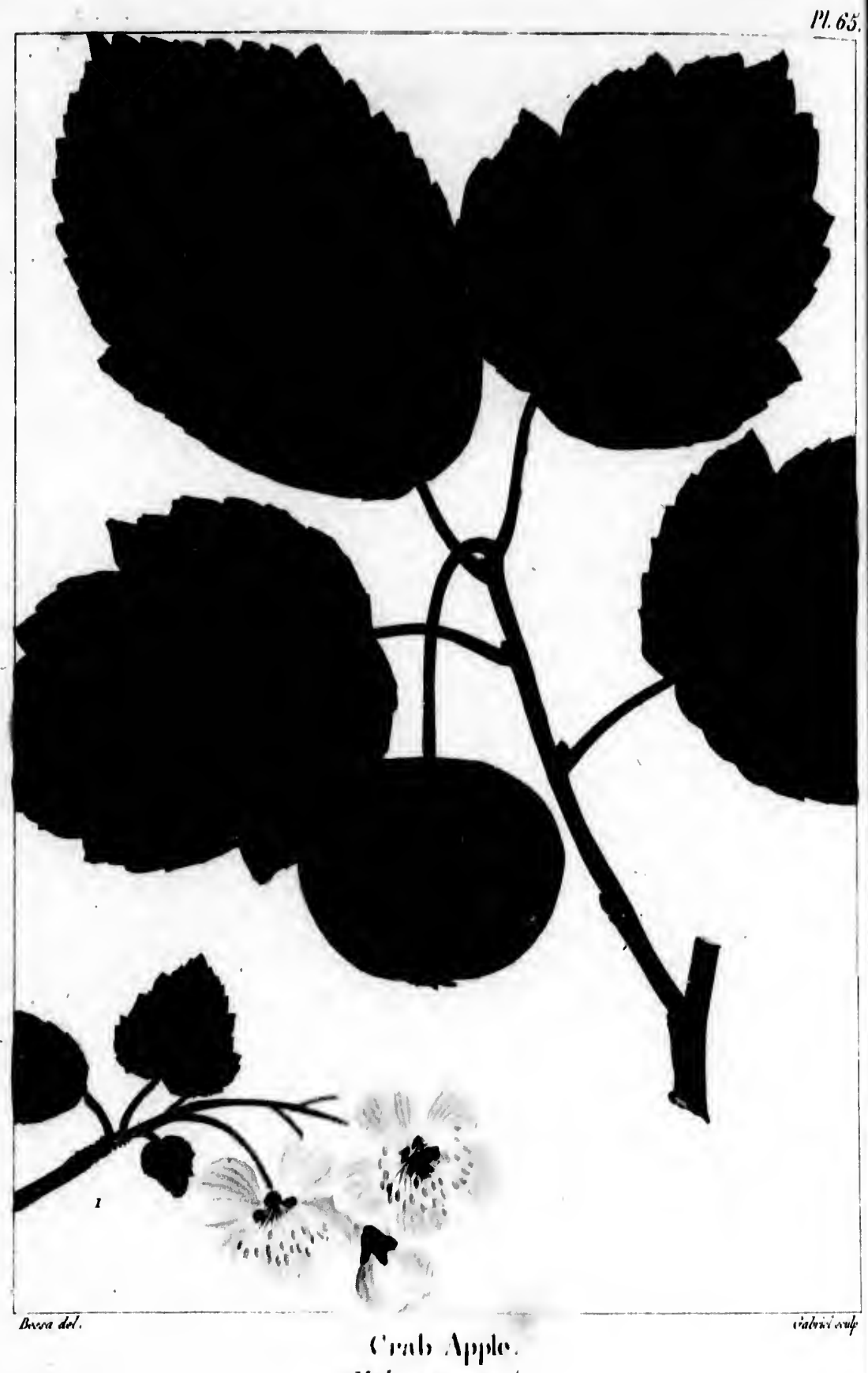

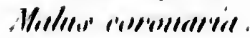




\section{GRAB APPLE.}

Icosandria pontugynia. Lunn.

Rosacre. Joas.

Malus cononaria. M: folitis lato-opalibus, basi rotundat tis, sub-angulatis, serratis, nitide glabris; pedunculis conymabosis; fructu pareo, adorata.

A species of Wild Apple Tree is found in North America, whose nature has not yet been modified by cultivation. 'The Wild Apple Tree of Europe, in a long series of years, has yielded a great number of species and varieties of fruit, which, in France alone, amount to nearly three hundred. Except the District of Maine, the State of Vermont, and the upper. part of New Hampshire, the Crab Apple is found, on both sides of the mountains, throughout the United States : but it appears to be most multiplied in the Middle States, and especially in the back papts of Pennsylvania and of Virginia. It abounds, above all, in the Glades, which is the name given to a tract 15 or 18 miles wide, on the summit' of the Alleghanies, along the road from Philadelphia to Pittsburgh.

The ordinary height of the Crab Apple Tree is 5 or 18 feet, with a diameter of 5 or 6 inches; but it is some. times found 25 or 30 feet high, and 12 or 15 inches in diameter. The two stocks which. I found by measure- 
ment to be of this size, stood in a field which had long been under cultivation, and this circumstance may have contributed to their extraordinary growth. They were insulated trees that in appearance exactly resembled the common Apple Tree. I have universally remarked that the Cirab Apple grows most favourably in cool and moist places, and on fertile soils.

The leaves of this tree are oval, smooth on the upper surface, and, when fully developed, very distinctly toothed : some of them are imperfectly three-lobed. While young they have a bitter and slightly aromatick taste. Which leads me to believe that, with the addition of sugar, they would make an agreeable tea. Like the common Apple Tree, this species blooms very early in the spring. Its flowers are white mingled with rose colour, and are collected in corymbs ; they produce a beautiful effect, and diffuse a delicious odour, by which, in the Glades where the tree is abundant, the air is perfumed to a great distance. The apples, which are suspended by short peduncles, are small, green, intensely acid, and very odoriferous. Some farmers make cider of them, which is said to be excellent : they make very fine sweet-meats also, by the addition of a large quantity of sugar.

No attempts have been made in the United States to improve the fruit of the Crab Apple Tree, nor any experiments of uniting it, by grafting, with the species imported from Europe. These species succeed so per- 
CRAB APPLE:

335

fectly, and furnish such excellent new varieties, that much time would be spent upon the Crab Apple, without bringing it to as high a state of improvement. Perhap it might be cultivated with advantage for cider; but, aside from its utility in this way, it must be re. gadded only as a tree highly agreeable for the beauty of its flowers and for the sweetness of its perfume:

PLATE LXVi:

A branch with leaves and fruit of the natural size. Fig. 1 , A bunch of flowers. 
336.

\section{JUNE BERRY.}

Mzsphus anmonea. M. foliis sub-ovalibus, serratis; adullis glabris; nacemo simplici, elongato; florifero lanuloso; petalis oblongis; fructibus atropurpureis, edulibus.

Mespilue canadenuis. A. Micw. Flor, Bor, Am.

Wirn the exception of the marilime parts of the Carollinas and of Georgia, this tree is spread over the whole extent of the United States and of Canada ; but it is most multiplied upon the Alleghany mountains, and upon the elevated banks of the rivers which flow from them. In the Northern Section of the Union it is. culled Will Pear Tree, and in the Middle States, June Berry; which latter name I have adopted because it is. universally employed in the regions where the tree is most abundant, because it indicates that in maturing its. fruit it is among the earliest trees, and because the Mespillus urborea is remole from all resemblance to the Wild. Puar True.

In the vicinity of New York and Philadelphia, the Junc Berry appears to grow of preference in moist and sharly situations, and along the margin of brooks and rivuluts. In the Western Country, it is found in the midst of the forest among the Oaks, the Walnuts, the 
; adul:unloso;

r. Am.

of the

er the

; ; but tains, I flow $n$ it is June $e$ it is tree is ing its. MesWild

, the t and $s$ and n the , the

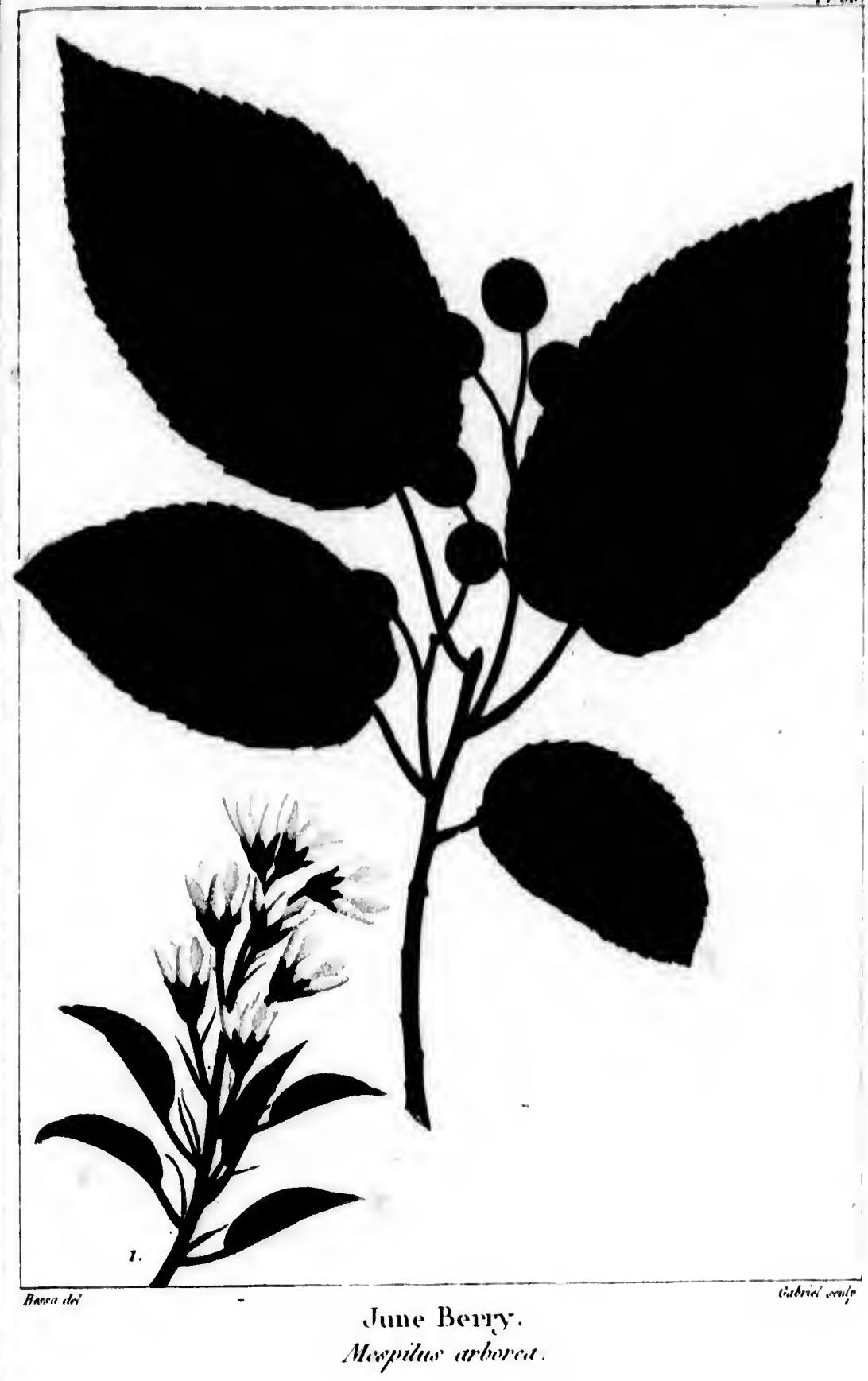




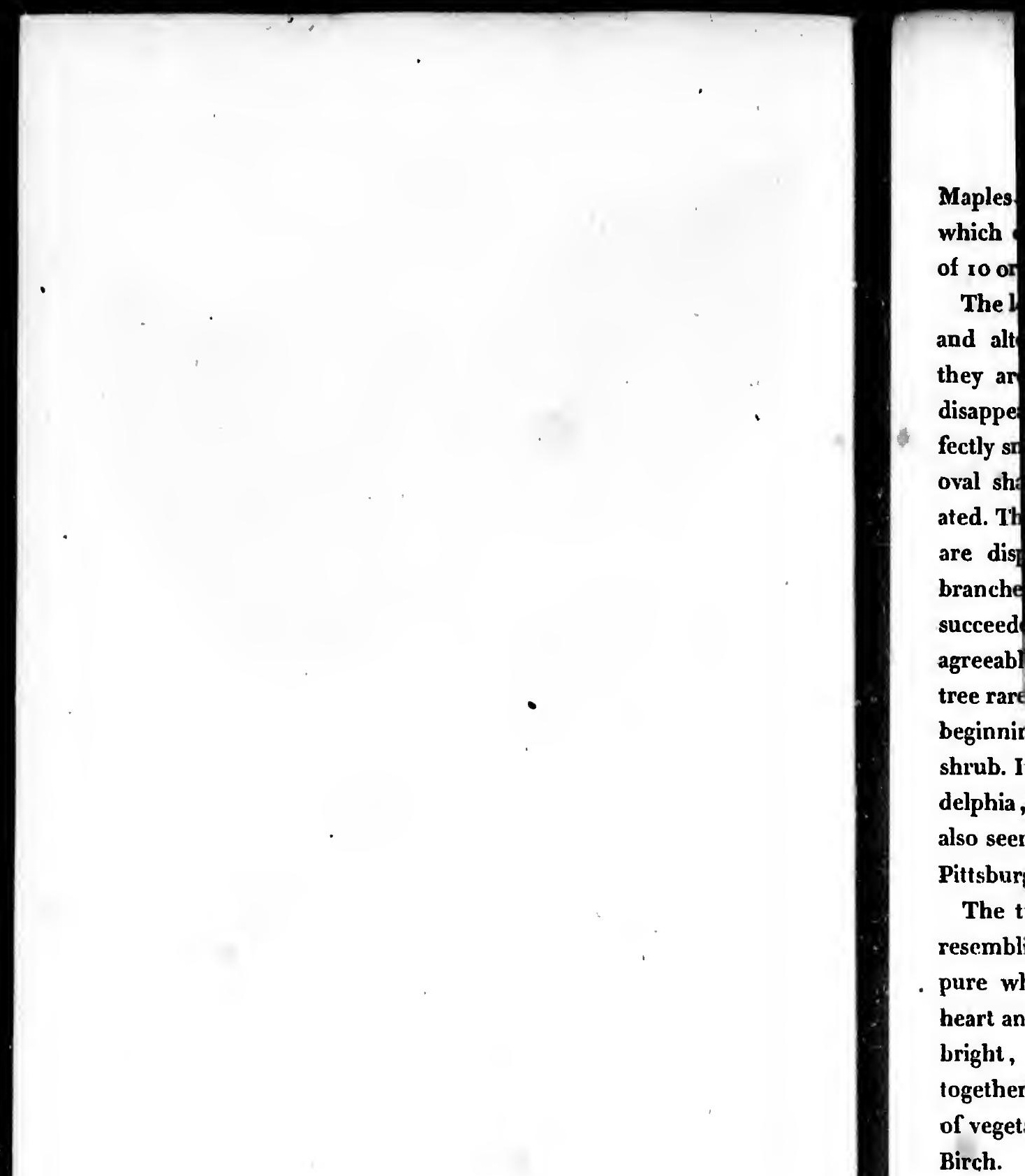


Maples, etc. Here also it reaches its greatest height; which does not exceed 35 or 40 feet, with a diameter of 10 or 12 inches.

The leaves of the June Berry are 2 or 3 inches long; and alternately arranged. When beginning to open; they are covered with a thick, silvery lown, which disappears with their growth, and leaves them perfectly smooth on both sides. They are of a lengthened oval shape, of a delicate texture, and finely denticulated. The flowers, which are white and pretty large; are disposed in long panicles at the summit of the branches ; they blow in the beginning of April, and are succeeded by small fruit of a purplish colour and of an agreeable, sweet taste. This fruit, of which the largest tree rarely yields more than half a pound, is ripe in the beginning of June, before that of any other tree or shrub. It is sometimes brought to the market of Philadelphia, where it is bought only by children : I have also seen small quantities of it exposed in the market of Pittsburgh.

The trunk of the June Berry is covered with a bark resembling that of the Cherry Tree. Its wood is of a - pure white, and exhibits no difference between the heart and the sap; it is longitudinally traversed by small, bright, red vessels, which intersect each other and run together. This peculiarity, which deserves the attention of vegetable physiologists, is also observable in the Red Birch. 
The fruit of this tree is, in my opinion, too small and too scanty to reward the pains of meliorating the taste and of increasing the volume by long continued cultivation; but its early and beautiful flowers entitle it to notice as ari ornamental vegetable.

\section{PLATE LXVI,}

$A$ branch, with leaves and fruil of the natural size. Fig. 2, Flowers of the natural size. 



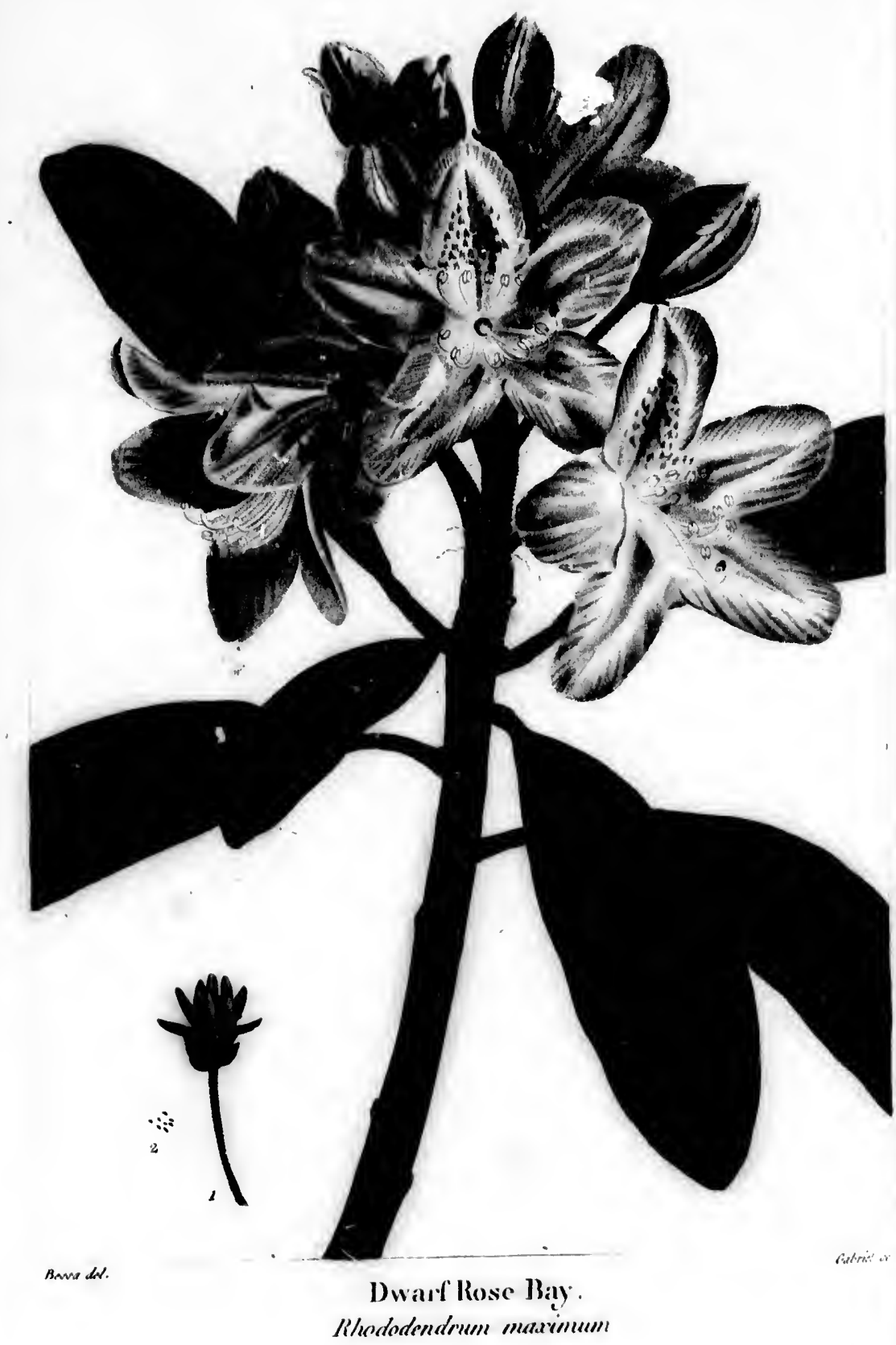




\section{DWARF ROSE BAY.}

Decandria monogynia. LIN

Rosacez. Juss.

RHododendnum maximum. $\boldsymbol{R}$. aiborescens; foliis subcuneato-oblongis, abruptè-acuminatis, crassis, coriaceis, glabris; calicibus laciniis, ovalibus, obtusis; corolld subcampanulata.

TuE Dwarf Rose Bay generally presents itself in the form of a shrub, of less than 10 feet in height; but as it sometimes rises to the height of 20 or 25 feet, with a diameter of 4 or 5 inches, its diffusion thronghout a large part of the United States, and the remarkable beauty of its flowers have induced me to describe it.

The west end of Long Island, and the river Hudson below the Highlands, may be considered as the limit, far beyond which the Dwarf Red Bay ceases to be found in the forests. It is abundant, on the contrary, in the Middle States, and in the upper parts, particularly in the mountainous tracts, of the Southern Section. It is almost exclusively seen on the borders of creeks and rivers, and is observed to be more multiplied in approaching the Alleghanies, till, in the midst of these ranges, especially in Virginia, it becomes so abundant on the sides of the torrents, as to form impenetrable thickets, in which the bear finds a secure retreat from the pursuit of the dogs and of the hunters.

II. 
Deeply shaded situations, in the vicinity of cool and crystal waters flowing among rocks, where the atmosphere is laden with vapour, are the most congenial to the Dwart Rose Bay and to the Mounlain Laurel. Shade and humidity seem to be indispensible to the Dwart Rose Bay, for it flourishes among the White Cedars in the gloomy swamps of Lower Jersey, where the surface of the miry soil is carpeted with moss constantly surcharged with moisture.

When the leaves of the Dwarf hose Bay are beginning to unfold themselves they are rose-coloured, and are covered with red down; when fully expanded they are smooth, 5 or 6 inches long, of an elongated oval form, and of a thick, coriaceous texture. They are ever-green, and are partially renewed once in 3 or 4 years.

The flowers are cominonly rose coloured, with yellow dots on the inside, and sometimes they are perfectly white. They are always collected at the extremity of the brauches in beautiful groups, which derive additional lustre from the foliage which surrounds them.

The seeds are extremely minute, and are contained in capsules that open in the fail, for their escape.

The wood of the Dwarf Rose Bay is hard, compact and fine grained; lut it is inferior in these respects to that of the Mountain Laurel. do not know that it is appropriated to any use.

This shrub bas long existed in Europe; but as it re- 
DWARE ROSE HAY.

quires a cooler and more shady exposure, and more assiduous culture than the Rhododendrum ponticum; which is a native of the Alps and of the Pyrennees, it is less extensively. multiplied. The Dwarf Ruse Bay with white flowers is only a variety of the species $I$ have been describing.

\section{PLATE LXVII.}

A branch, with leaves and flowers of the natural size. Fig. I, A seed vessel. Fig. 2, Seeds. 


\section{MOUNTAIN LAUREL.}

Decandria monosynia, Linn.

Rosacese. Juss.

Кадмга гатіғоци. $\boldsymbol{K}$. arborescens; foliis petiolatis ovalibru, coriaceis, glabris; corymbis terminalibus, viscidopuberulis.

The Mountain Laurel is a large shrub, which, if its height alone is considered, appears, like the preceding species, to be exclusled from the class of vegetables which I have assumed the province of describing more particularly than has been done by preceding authors; but the uses which are beginning to be made of its wood entitle it to our notice. It bears indifferently the names of Mountain Laurel, Jaurel, Ivy, and Calico Tree.

'The west end of Long Island, and the vicinity of Poughkeepsic, which lies on the river Hudson, between the $42^{\circ}$ and $43^{\circ}$ of latilude, may be considered as nearly the northern limit of the Mountain Iaurel. I have never seen it on the shores of lake Champlain, nor on the banks of the river Molıawk, where, in situations otherwise congenial, its growth is probably forbidden by the scverity of tho witter. It abounds in New Jersey, and covers Wechock IIill, nearly opposite to the city of 
is ovaliviscidd-

, if its eceding zetables g more uthors ; e of its ferently I Calico inity of etween s nearly e never on the uations birlden Jersey, city of

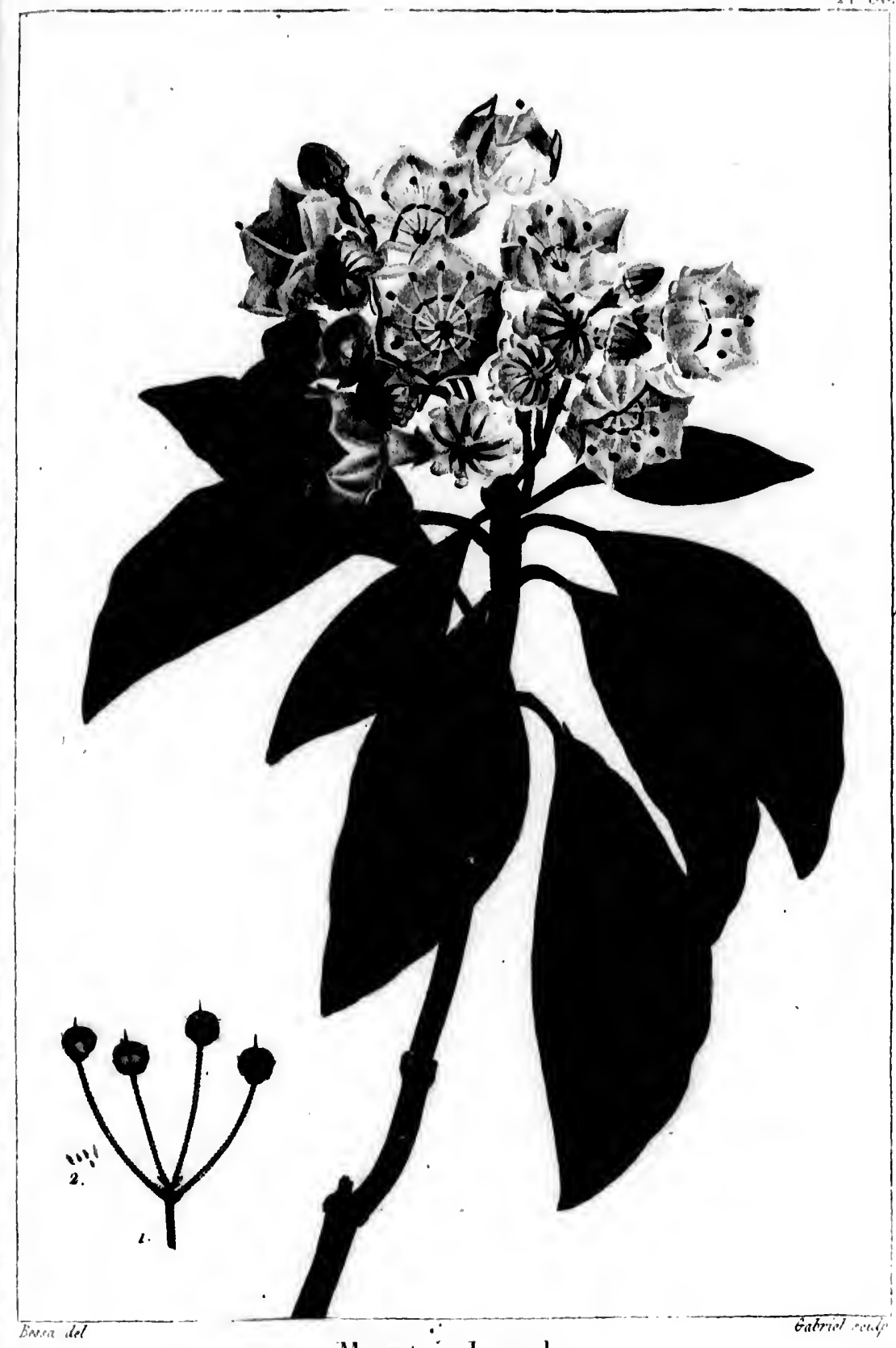

Mountain Laurel. Kanlmiar lanifolia 


\section{New}

imme

thence

steep

ghany

comm

towar

towar

and in disapp

try, w Allt rivers

tionall

lains, 1

in $\mathrm{Ger}$

multip

vegetal

of the

acres,

of the

in hei the cr with copses

with

the ap

trees. 
New York. It grows also near the Schuylkill, in the immediate neighbourhood of Philadelphia. Proceeding thence towards the south-west, it is found along the steep banks of all the rivers which rise in the Alleghany mountains; but it is observed to become less common in following these streams from their source; towards the Ohio and Mississippi on one side, and towards the Ocean on the other. It is rare in Kentucky and in West Tennessee, and in the Southern States it disappears entirely when the rivers enter the low country, where the pine-barrens commence.

Although the Mountain Laurel abounds along the rivers of the Middle and Southern States, it is proportionally less common than upon the Alleghany Mountains, from Pennsylvania to the termination of the chain in Georgia. I have no where seen it more profusely multiplied, nor of a greater height and more luxuriant vegetation, than in North Carolina, on the loftiest part of the Alleghanies. It occupies tracts of more than 100 acres, and forms upon the summit, and for a third of the distance down the sides, thickets 18 or 20 feet in height, which are rendered nearly impenetrable by the crooked and unyielding trunks, crossed and locked with each other. As the shrubs which compose these copses are of an uniform height, and richly laden with ever-green foliage, they present, at a distance; the appearance of verdant meadows, surrounded by tall trees. 


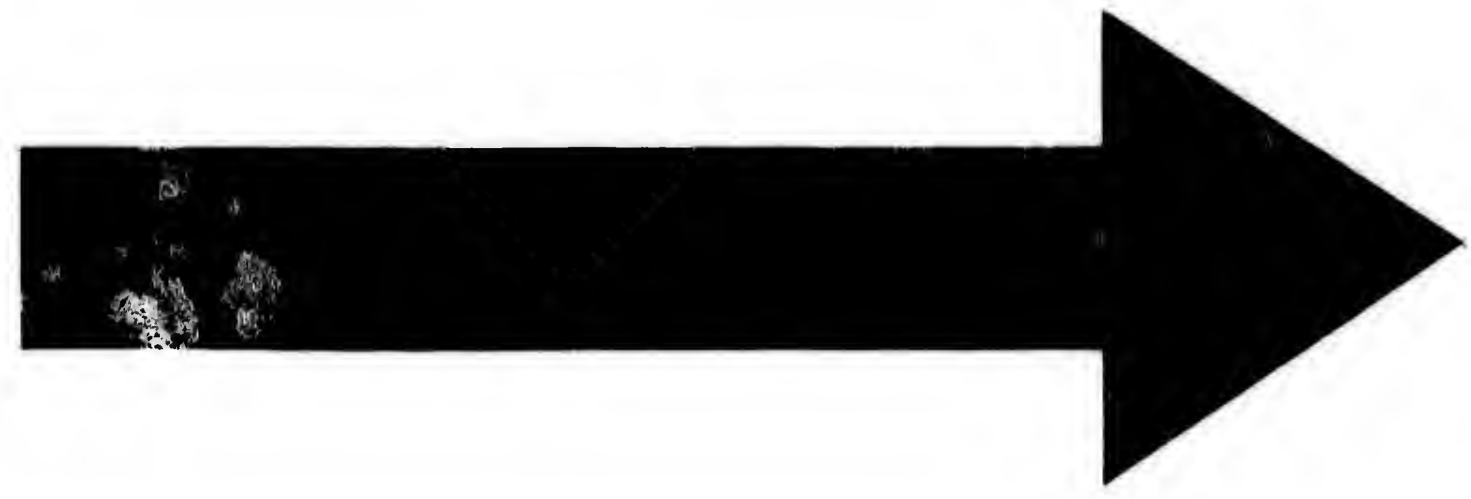




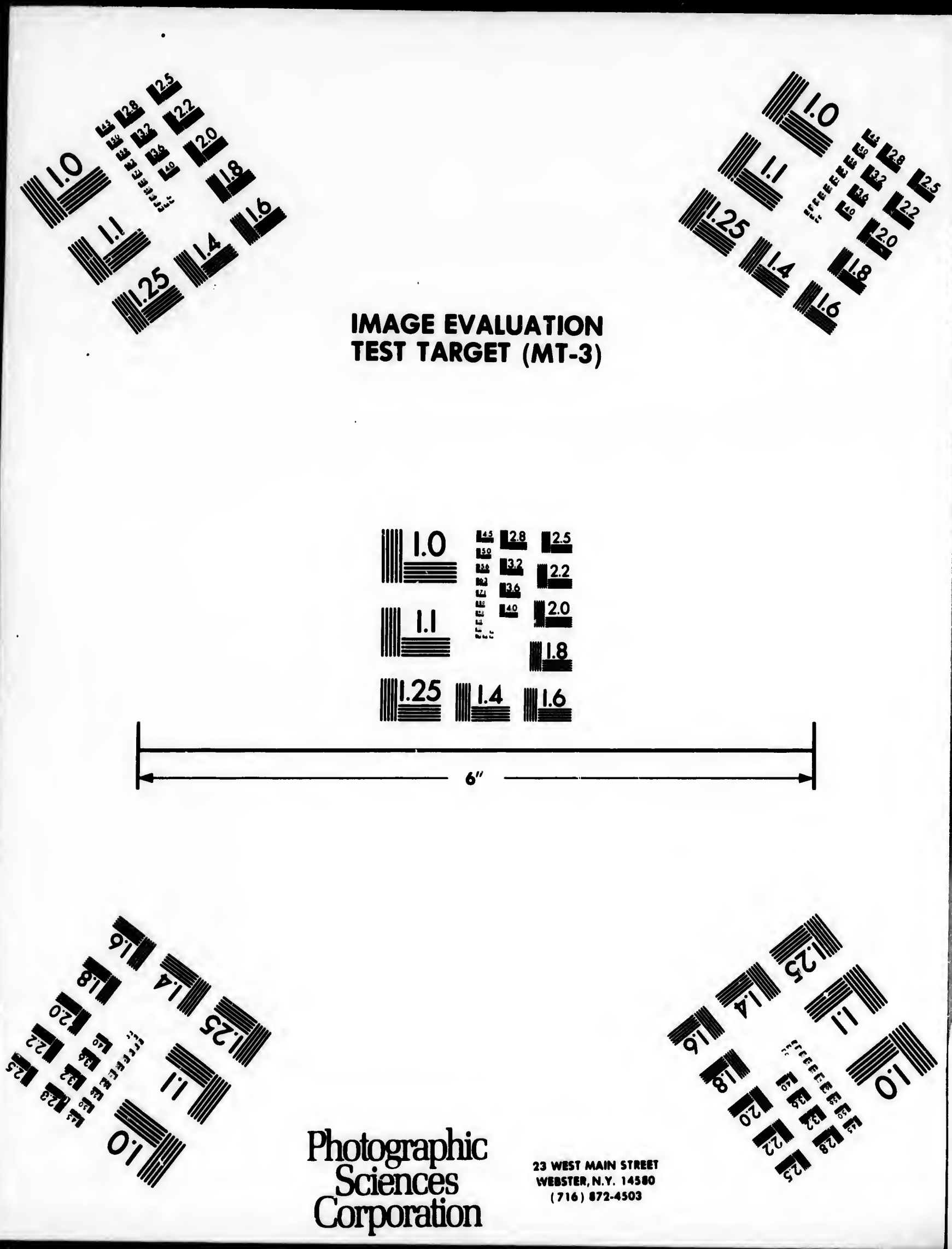



The leaves of the Mountain Laurel are of a corinceous texture, oval-acminate, enting and about 3 if iches long. The flowers, which are idestitute of odour, are disposed in corymbs at the extremity of the branches : in general they are of a beautiful rose colour, , and sometimes of a pure white. They are always numerous, and their brilliant effect is heightened by the richness of the surrounding foliage; hence this shrub is in great request for the embellishment of gardens. The minute seeds are contained in small, globular capsules.

On the declivities of the Alleghanies, in North Carolina, where I have observed the largest Mountain Laurels, the trunk is generally 3 inches in diameter. The wood, particularly that of the roots, is compact, fine grained, and marked with red lines. When dry it is very hard, and it turns and polishes well. At Philadelphia it is selected for the handles of light tools, for small screws, boxes, etc. : it is said also to make good clarinettes. Probably the Laurel will hereafter be more extensively employed, as of all American shrubs its wood most nearly resembles the Box wood, and is most proper to supply its place. I have been assured that its leaves are narcotick, and that they are poisonous to cattle.

The Mountain Laurel was long since introduced into Europe, where it is multiplied for the beauty of its flowers and of its foliage; but many years are necessary 
MOUNTAIN LAUREL.

345

to obtain it, from the seed, in a condition to bloom. $A$ soft, Loose and cool soil and a norther exposure, appear to be most congenial to its growth.

PLATE LXVII.

A branch, with leaves and flowers of the natural size. Fig. 1, A seed vessel. Fig. 2, Seeds. 
346 


\section{B I R G H E S.}

The northern extremity of the Old and New Continents is the native climate of the Birch, if we may judge from the number of species which is found there, and which diminishes in descending towards the South. To the inhabitants of regions destitute of most of the larger vegetables, which flourish in more temperate climatés, the trees of this genus are highly interesting, and are applied by them, with wonderful ingenuity, to the necessities of life : they employ the wood in the construction of houses and of ressels, and in the works of the wheel-wright and of the cabinet-maker; of the bark, which is nearly incorr.stible, they make canoes, boxes, and a more secure covering for their habitations; with the leaves they die their nets; and from the sap they procure a mild and sugary beverage.

From the researches of botanists it results, that as many species of Birch are found in the northern part of the United States as in Europe; and from my own observations on the comparative properties of their wood, the advantage appears to lie wholly on the side of the American species. Thus the Canoe Birch equals the White Birch, which grows in Sweden and in Russia ; 
and the Cherry Pirch and Yellow Birch far exceedfitin the strength and beauty of their wood, as is prover by the uses to which they are applied in Canada and in the Norihern and Middle Sections of the United States.

Of the seven species of Birch which have been discovered in North America, five may be ranked among tall trees; the two remaining species, of which, for that reason, no mention will be made, are classed with the shrubs.

I have observed, in the form and disposition of the aments of the different species of American Birch, a distinction, in my opinion sufficiently marked to authorize the division of them into two seetions : the first section consists of the species which have long, flexible, and pendulous aments, and comprises the Canoe Birch and the White Birch, to which is added the Common European Birch; the second section is composed of the species whose aments are short and straight, namely, the Red Birch, the Black Birch, and the Yellow Birch.

$I$ have been led to this division by the external appear. ance, rather than by a minnte physiological examination of the sexual parts of the different species, leaving the accomplished botanist to decide upon its adoption. 


\section{METHODICAL DISPOSITYOON \\ OF THE BIRGHES.}

Monuccia polyandria. Liss. Amentacue. Juss.

FIRST SECTION.

Fertile aments, pedunculated and pendulous.

. Canoe Birch. . . . . . . Betula papyracea.

2. Common European Birch. . Betula alba.

2. White Birch. . . . . . Betula populifolia.

SECOND SECTION.

Fertile aments, sessile and erect.

4. Red Birch. . . . . . . Betula nubra.

5. Yellow Birch. . . . . . . . Betula lutea.

6. Black Birch. . . . . . Bctula lenta. 


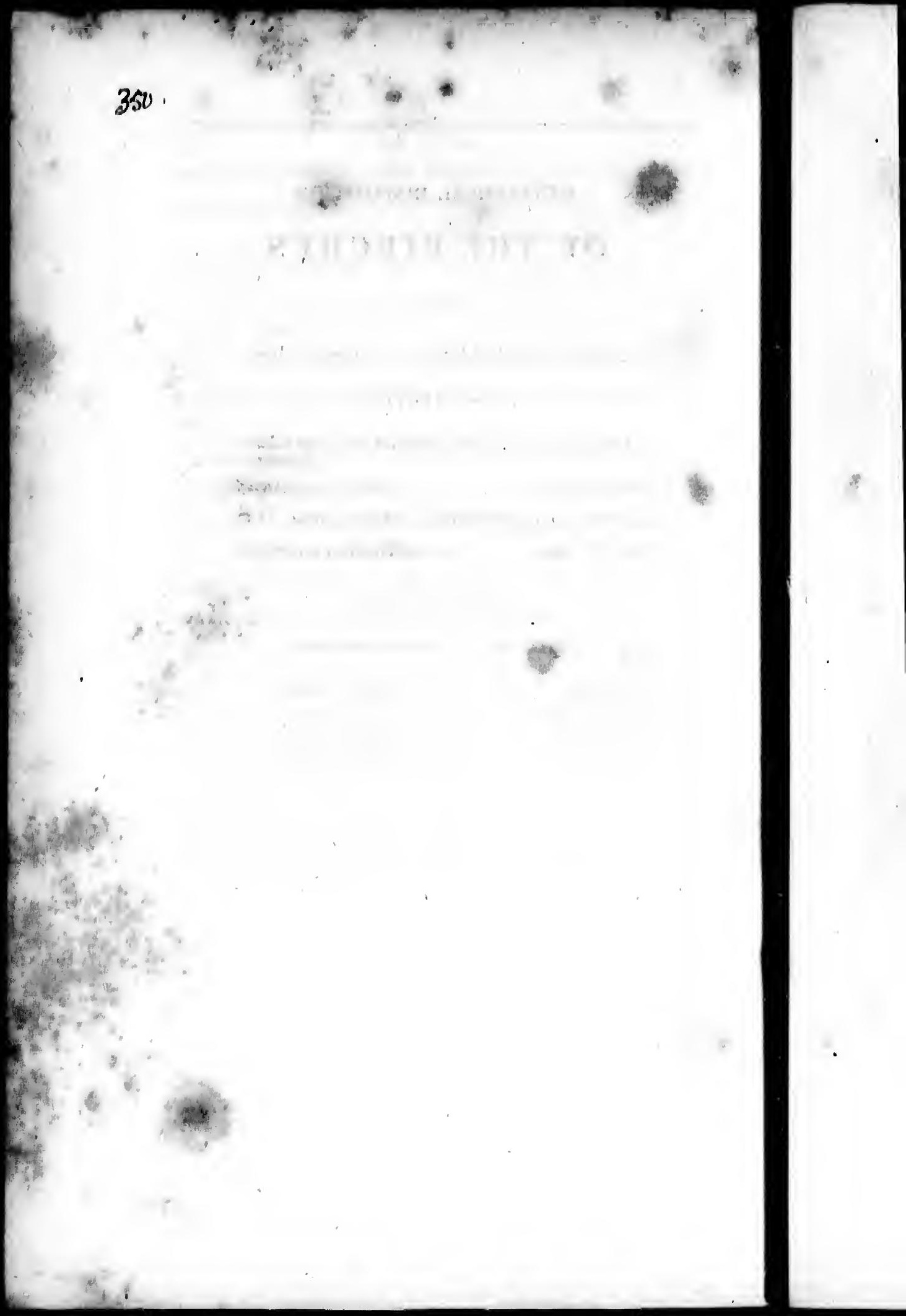





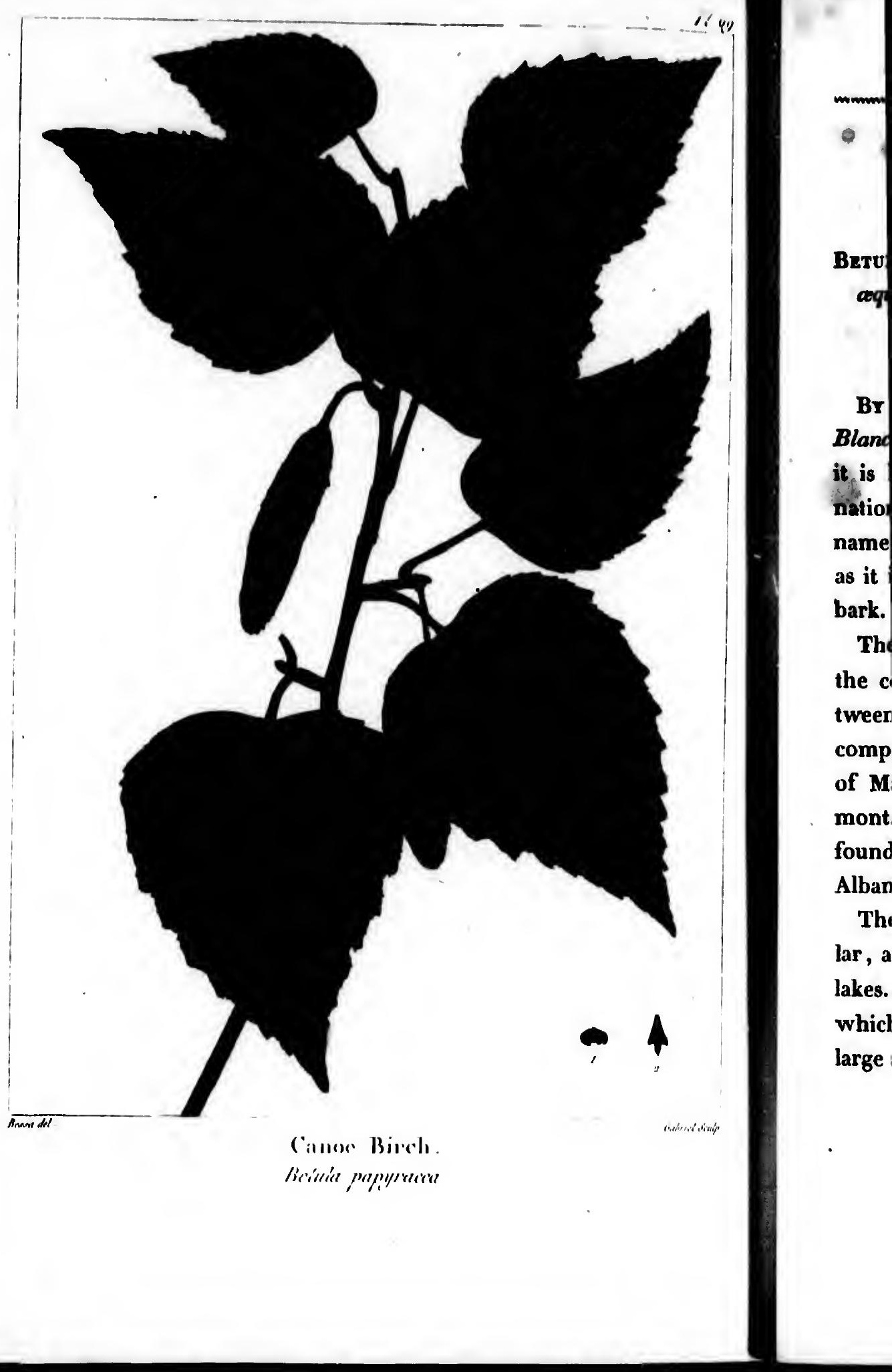




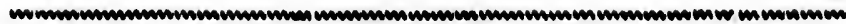

Q

\section{CANOE BIRCH.}

Betula papyracen. B. foliis ovalibus, acuminatis, subaqualiter serratis; petiolo glabro; venis subtis hirsutis.

Betula papyritera. A. Mici. Flor. Bor. Am.

Br the French Canadians this tree is called Boulears Blanc, White Birch, and Bouleau d Canot, Canoe Birch: it is known to the Americans also by these denominations, and sometimes by that of Paper Birch. 'The name of Canoe Birch appears to be the most proper, as it indicates an important use which is made of its bark.

The Canoe Birch is most multiplied in the forests in the country lying north of the $43^{\circ}$ of latitude, and between the $7^{\circ}$ of west longitude and the Atlantic Ocean; comprising Lower Canada, New Brunswick, the District of Maine, and the States of New Hampshire and Vermont. It ceases below the $4^{\circ}$ of latitude, and is not found in the southern part of Connecticut, nor below Albany, in the State of New York.

The surface of these regions is, in general, very irregular, and is diversified in every direction with hills and lakes. It is occupied by thick and gloomy forests, of which the soil is fertile and principally covered with large stones, overgrown with moss. This part of North 
America, though situated 10 degreeg farther couts, very nearly resembles Sweden and the cantern part of Prussia, not only in the face of the so but in the. severity of the climate.

The Canoe Birch attains its largest size, which is about 70 feet in height and 3 feet in diameter, on the declivity of hills and i the bottom of fertile vallies. Its. branches are slender, flexible, and covered with a chining, brown bark, dotted with white. The leares are borne by petioles 4 or 5 lines long, and are of a middling sire, oval, unequally denticulated, smooth, and of a dark green coloux. The aments are pendulous, and about an inch in length : the seeds are sipe tawards the middle of July.

The heart or perfect wood of this tree, when firet Jaid open, is of a reddish hue, an "anly axp is perfectly white. It has a fine, glassy grain fun a conoiderable share of atrength : that it is but little employed is attributable partly to its speedy decay when exposed to the. succession of dryness and moisture, and partly to the existence, in the countries which produce it, of several species of wond, such as the Maples, the Beech, and even the Yellow Birch, which are far preferable for the uses of the joiner and the wheel-wright. It is fully equal, however, to the White Birch which grows in Sweden and Norway, and which, for many purposes, is advantageously substituted for the Oak : but these countries are destitute of trees analogous to those which have

ine the $\mathrm{C}$ frequer mahog

A se length hibits $v$ banche divided Boston general wivits.

'The ported Boston. On tr is of a Sweden Trees Ic the for contain This ba to man the cou below 1 netrabl portfol dered 
ive been mentioned as enriching the native soil of the Canoe Birch. In the Diatrict of Maine, tables are frequently the of $\mathrm{ll}$, and stained in imitation of mahogany.

A section of the trunk of this tree, 1 or 2 feet in length, immediately below the first remilication, exhibits very elegent undulations 3 the fibre, representing bunches of feathers or sheaves of corn : these picces are divided into thin plates for inlaying mahogany, and in Boston and the towns situater farther north, they are renerally employed by cubinet-makers to embellish their wurk.

The Cance Birch afiords excellent fuel, and is exported in great quantities from the Diatrict of Maine to Boston.

On trees not ing 8 inches in diameter the bark is of a brilliant wner, like that of the White Birch of Sweden, and, like that ton, $t \boldsymbol{t}$ is almost indestructible. Trees long since prostrated by time are often met with in the forests , whose trunk appears sound, while the bark contains only a friable substonce, like vegetable monld. This bark, like that of the European species, is devoted to many uses : in Canada and in the District of Maine the country people place large pieces of it immediately below the shingles of the roof, to form a more impenetrable covering for their houses; baskets, boxes and portfolios are made of it, which are sometimes embroidered with silk of different colours; divided into very 
thin sheets, it forms a substitute for paper; and, placed between the soals of the shoes and in the crown of the hat, it is a defence against humidity. But the most important purpose to which it is applied, and one in which it is replaced by the bark of no other tree, is the construction of canoes. To procure proper pieces, the largest and smoothest trinks are selected : in the spring two circular incisions are made several feet apart, and two longitudinal ones on opposite sides of the tree; after which, by introducing a wooden wedge, the bark is easily detached. These plates are usually 10 or 12 feet long, and 2 feet 9 inches broad. To form the Canoe they are stitched together with fibrous roots of the White Spruce, about the size of a quill, which are deprived of the bark, split, and suppled in water. The seams are coated with resin of the Balm of eilegd. Great use is made of these canoes by the savagee and by the French Canadians in their long journies into the interior of the country : they are very hight, and are easily transported on the shoulders from one lake or river to another, which is called the portage. A canoe calculated for four persons with their baggage weighs from 40 to 50 pounds; some of them are made to carry fifteen passengers. Such are the ordinary uses of the bark and of the wood of this tree,

The Canoe Birch flourishes in the vicinity of Paris, where it is known in the nurseries by the name of Betula nigra, Black Birch. If it is found to grow with 
success upon poor lands, it will prove a valuable acquisition to the European forests, as it surpasses our. native Birch th stature and in the quality of its wood.

\section{PLA'TE LXIX.}

A branch, with leaves and fertile aments of the natural size. Fig. I, A seed. Fig. 2, The scale which covers the seed. 


\section{COMMON EUROPEAN BIRCH.}

Betura 1L8a. B. foliis deltoidibris, acutis, duplicato-sernatis, glabris; strobilorum symamis lobis lateralibus rotundatis; petiolis glabris, podunculis longionibus.

OF all the lealy trees of the Old Continent, the Birch is found in the highest latitude : it grows as far north as the joth degree, though its vegetation is so much repressed by the excessive cold of the winter, that it is reduced to the size of a shrub. A few degrees farther south, it attains its fullest developement, and it is the most common, the tallest, and the most robust of the leafy trees which compose the forests between the 65th and 55th degrees of latitude; in which interval are comprised Iapland, Norway, Sweden, and a great part of Russia. Proceeding still farther south, the Birch is observed to become less common in the forests in proportion as the Maples, the Beeches, the Elms and the Oaks become more abundant. In France, between the 4 Sth and 45th degrees, it appears to suffer from the influence of too dry and too warm an atmosphere ; for it is inferior, in size and in the quality of its wood, to the same species in the north of Europe. The 45th parallel may be assumed as the limit below which the Birch is 


$$
\text { t }
$$


only ac mount: with pe In $\mathbf{G}$ 8n feel France trunk thick b lar to $t$ small $b$ just me colour The barren same ts aments ish. si very st the to scale, The le and is the ag which. than al In $t$ variety selves, 
only accidentally found in the forests, if we except lofty, mountains, whose elevation tempers the atmosphere with perennial coolness.

In Germany, Sweden and Russia, the Birch is 70 or 8o feet high, and; about 2 feet in diameter; but in France it rarely exceeds two thirds of this height. The trunk and limbs of the harge trees are covered with a thick bark, whose epidermis is white and perfectly similar to that of the White Bineh and the Canoe Birch. The small branches, likewise, resemble those of the species just, mentioned, being slender; flexible, and of a brown colour spotted with white.

The Birch blonms early in the spring; the fertike and barren flowers are borne by different byanches of the same tree. The barren flowers are disposed in pendulous aments about an inch long; the fertile flowers are greenish. small, and not conspicuous. The seeds also are very small, and are collected round a common stem, in the form of aments : each of them is covered with a scale, and furnished with two menaturancous wings. The leaves are alternate, nearly triangular, acuminate and irregularly tuothed; they vary in size according to the age of the tree and to the nature of the soil on which. it grows; in very dry lands they are not more than an inch in length.

In the north of Europe-the Birch affords a singulap variety of resources to the inbabitants, who serve themselves, with admirable ingenuity., of its.wood, its bark, 
and its leaves. But the expedients to which they are obliged to have recourse, for defence against the extreme intensity of the cold, prove how litte these regions have been favoured by the Creator. In Sweden, Norway and Finland, this wood is most commonly employed by the wheel-wright, and serves for the manufacture of almost all the implements of husbandry. It is used by turners for bowls, plates, spoons, chairs, etc. The trunk, like that of the Canoe Birch, affords pieces immediately below the first ramilication, which, when polished, present beautiful wavings of the grain, and which form elegant articles of furniture.

The bark is also subservient to a great variety of economical uses : boxes, baskets and sandals are made of it; it is placed between the soals of shoes, or in the crown of the hat, as a defence against humidity ; and sometimes it is wrapped round the lower part of posts to preserve them from decay. It endures many years uninjured, even when exposed to the vicissitudes of the atmosphere. To prepare the skin of the rein-deer, the Laplanders cut this bark into small pieces, which they macerate, and afterwards boil in water, with the addition of a little salt. The skins are plunged repeatedly into this decoction warmed, and are allowed to remain in it several days : when taken out they are vigorously curried to render them pliable and soft : thus prepared, they are hardly permeable by water. In Russia, by slowly burning the bark of large birches in kilns or furnaces,

an en is pre Th given habit to dy Th and, but it ment speci uses of $\mathbf{w}$ Nortl

En with variet not d uses ; prove to gr Henc analo north Oak, to be than also 
an empyreumatic oil is obtained, with which a Icather is prepared highly esteemed for durability.

The leaves of the birch, both green and dry, are given to cattle. When young, they are used by the inhabitants as a substitute for tea : they are also employed to dye wool of a yellowish colour.

The sap of the Birch is very abundant in the spring, and, by evaporation, it affords a syrop, rich and sugary, but incapable of crystallization: By the addition of fermenting mitter, this sap is converted into beer, into a species of wine, or into vinegar. Such are the principal uses of the European Birch, all the valuable properties of which are completely united in the Canoe Birch of North America.

England and the south of Germany being favoured with a milder climate and, consequently, with a greater variety of trees than the more northern countries, are not dependent upon the Birch for so great a variety of uses; but even here it is a valuable possession, as it is proved, by the experience of upwards of two centuries, to grow more rapidly. than any other tree in barren soils. Hence, in Europe, all dry, meager, gravelly lands, analogous to those which, in the centre and in the north of the United States, produce the Black Jack Oak, the Bear Oak, and the Scrub Oak, are found to be more profitably devoted to plantations of Birch than to any other species of culture: In this manner also they are gradually prepared for the growlh of 
more valuable trees, such as the Oaks, the Chesnuts, etc.

Plantations of Birch are formed by sawing the seed, or by setting out young plants collected in the wood, or, which is far preferable, procured from sursery. When the tirst method is employed, the ground should be turned with an iron-toothed harrow, in humid weatber in the month of November. Fifteen pounds of seed, including the scales, should be sown upnn an acre, and afterwards covered by drawing over it a how madeof brush-wood.

Nothing contributes more to the ouccess of the seeds: than previoushy burning the noxious herbs and bushes. growing upon the ground. It is observed in the north of Burope and of the United States, that the Birch reappears, as if by inchantiment, in forests that have been destroyed by tire. The Birch seed is sometimes mixed with rye which, springing - with the young plants, protects them during the first summer from the sun, and which, by the profit of the crop, indemnifies the bublandman for a part of the expence of forming his. plantation. It the ground is burthened with the young plants, a part of them may be taken up the third yearto fill the vacant spaces in woods composed of Oaks, of Pines, etc. They may be sold also to persons who prefer for'ming their coppices by transplantation, which is the mode generally employed in Europe. In the month of November holes are formed 5 feet distant, in a straight

line, weat mer the il tised requi Th desti hoop Ches for: 1 whid i I t pagat Old 4 tivati State: in $\mathrm{Ge}$ of fo the ix . Th foliag to th appe: speci seen most time 
COMMON ZUROPEAN BIRCH.

line, to which the young plants are committed, in humid weather which promises rain. In the course of the summer a day is chosen for bestowing a light tillage upon the land, to clear it of the noxious herbs, as is practised for Maize or Indian Com. This is all the labour required to ensure the success of the plantation.

-Theso coppices may be cut every five years if they are destined for making brooms, or every 8 or 9 years for hoops, which are sabstituted for those of Oak and of Chesnut fat in yoars of age they afford an excellent fuel for. báking brick-making, and for all manulactures which require a brisk and clear fire.

1: I have entered into these details concerning the propagation of the Birch, because, among the trees of the Old Continent, it is une of the most profitable for cultivation tupon poor lands. Proprietors in the United States; who iread the works which have been published in Germany, France and England, on the matugement of forests, will be able to.appreciate, in this respect, the importance of the Birch.

The European Birch is so nearly related in its bark, its foliage', the quality of its wood, and in other properties, to the White Birch and to the Canoe Birch, that it appears to occupy a middle place between these two species. Its principal resemblance to the White Birch is seen in its leaves, and in. its favourable growth upon the most sterile soils, upon those even which are at the same time meager and humid. The most remarkable diffe- 
$5 \sin$ COMMON EUROPRAN BIRCH.

rence consisls in the larger size of the European species, and in the superior quality of its wood. The inferiority of the White Birch is not attributable to the climate, for it exhibits the same dimensions in the district of Maine, and in Pennsylvania and Maryland. The White Birch of Europe and the Canoe Birch resemble each other in their wood, their bark, and their ample proportions, which are perhaps superior in the American species. They differ in the form of their leaves, and they grow on very different soils : the Cance Birch is exclusively attached to rich lands constantly cool, and capable of yielding an abundant harvest of corn or of clover, and it propagates itself naturally only in that part of North America which corresponds in climate to the 54th and 55th degrees of latitude in Europe. Between the White Birch of Europe and the Red Birch, I have, chserved, no resemblance, except in the suppleness of twigs; which is more remarkable in the Red Birch.

The length of this description will not be deemed superfluous by persons who justly appreciate the importance of precise ideas on subjects like the present.

\section{PLATE LXX.}

A branch, with leapes and aments of the natural size. Fig. I, A seed. Fig. 2, A scale which covers the seed. 



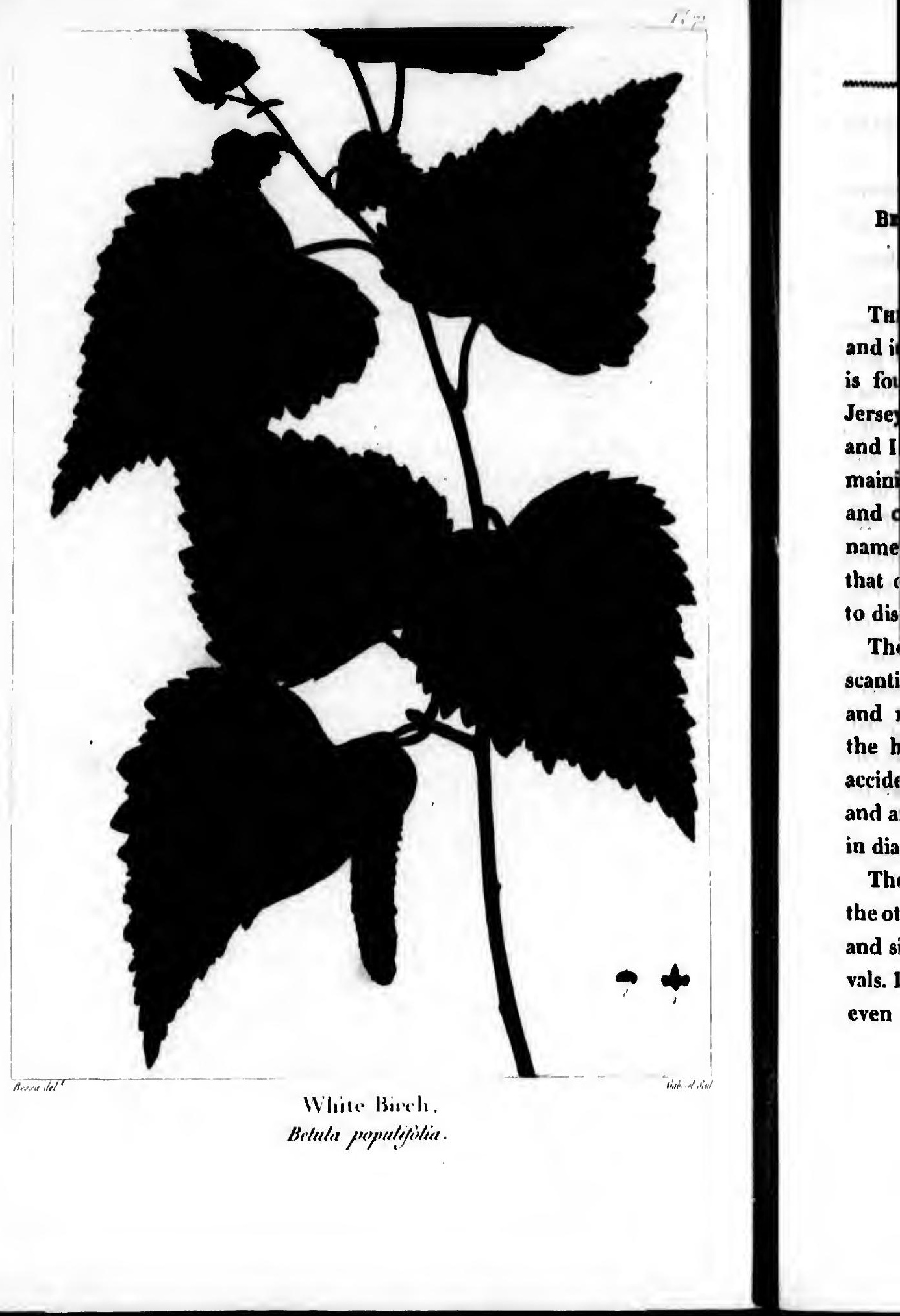




\section{WHITE BIRCH.}

Bztuga poptizirouta. D. fuliis longè acuminatis, incospualicer serrutis, slaberrimis.

Tus specien, like the Canos Bircls, grows in Canada and in the northern extremily of the United States : it is found also in the lower purts of New York, New Jersey and Pennnylvania. In Virginia it is more rare, and I venture to ansert that it does not exist in the remaining Southern States. In the environs of New York and of Philadelphia it is called White Birch, and this name is habitually used in the Diatrict of Maine, where that of Old Field Birch is also frequently employed, to distinguish the White Birch from the Canoe Birch:

The White Birch is most frequently found in places scantily furnished with woods, where the cail is dry and meager : in thewe situations it commonly rises to the height of 20 or 25 feet. Single trees, which grow accidentally in moist places, expand to an ampler size, and are sometimes 30 or 35 feet high, and 8 or 9 inches in diameter.

The White Birch appears to be less multiplied than the other trees of this genus $:$ it is rarely found in groups, and single trees are met with orly at considerable intervals. It is more common in the District of Maine; but, even here, it is secn only by the side of the high- 
ways, and in sandy soils that have been exhausted by cultivation.

On trees that are fully grown the branches are numerous, slender, and generally drooping. The leaves are smooth on both surfaces, heart-shaped at the base, very acuminate, and doubly and irregularly toothed. The petioles are slightly twisted, and the leaves are thus rendered more tremulous than those of trees on which this disposition is not observed. I have also remarked that the buds, a few days after their developement, are slightly coated with a yellowish, odoriferous substance. The trunk of this species is clad in a bark of as pure a white as that of the Canoe Birch and of the European Birch : but its epidermis, when separated from the cellular integument; is incapable of being divided, like that of the two preceding species, into thin olects; which constitutes an essential difference.

The wood of the White Birch is very soft, brilliant when polished, and perfectly white. From its speedy decay, and from the inferior size of the tree, it is employed for no use, not even for fuet. The twigs are too brittle for common brooms.

'This tree can boast of no utility which should entitle it to be introduced into the forests of Europe, or to be preserved in those of America.

\section{PIATE LXXI.}

A branch, with leapes and aments of the natural size. Fig. 1, A seed. Fig. 2, A scale. 
ted by

nume-

res are

base,

othed.

e thus

which

rarked

ment, $s$ sub$c$ of as of the arated being , into ence.

rilliant ;peedy is emre too entitle or 10

al size. 


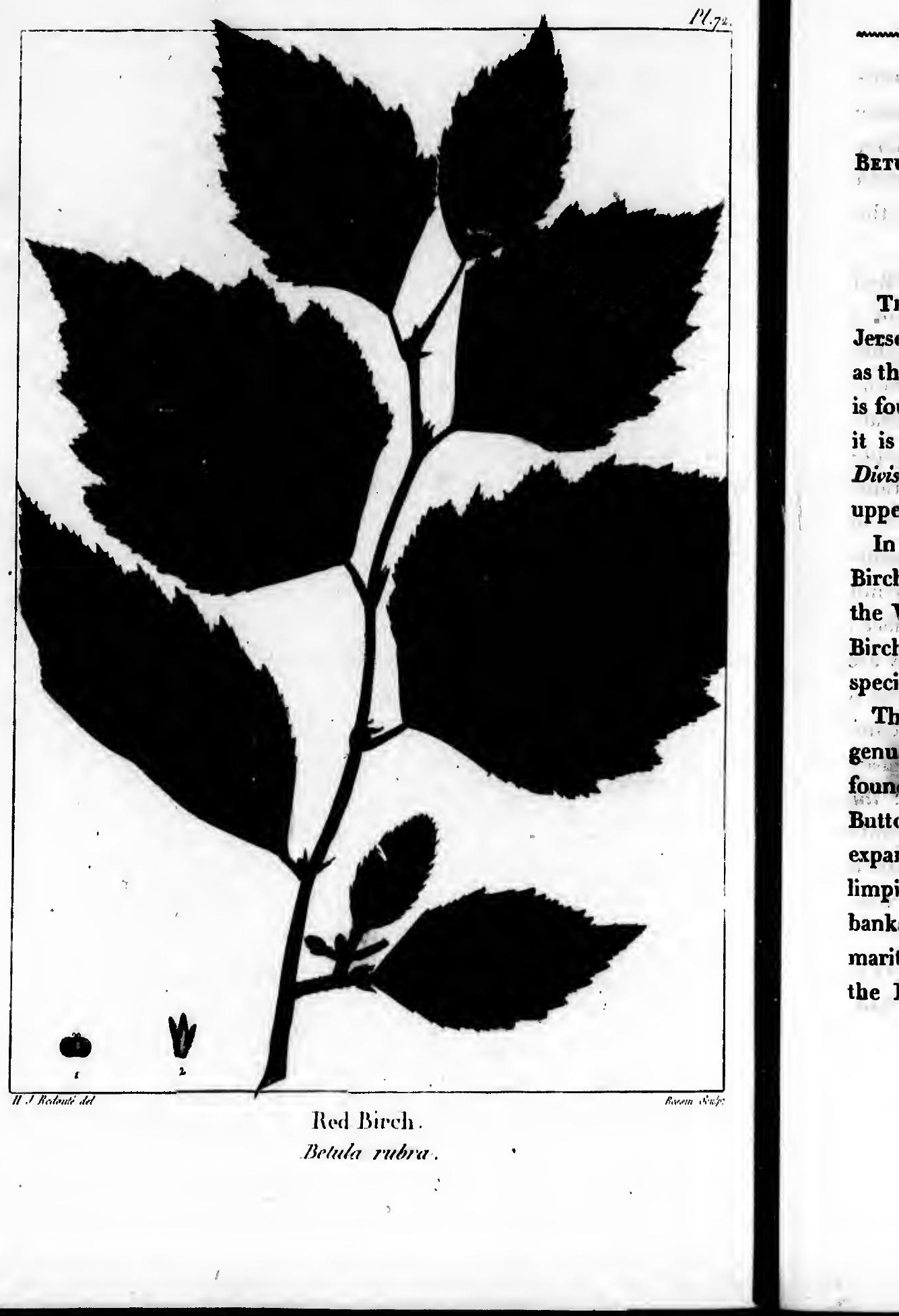




\section{RED BIRCH.}

BrTula nUBRA. B. foliis rhombeo-ovatis, acuminalis duplicato-serratis; petiolo brevi.

Betula nigra, Wisbi . Betulalanulusa, A. Micr. Elor..Bor. Am,

THE hanks of a small river near Kouacknack, in New Jersey, about 10 miles from New York, may be assumed as the most northern point at which this.species of Birch is found. I have never seen it in the Eastern States ; but it is abundant in those of the Middle and Southern Divisions, particularly in Maryland, Virginia, and the upper part of the Carolinas and of Georgia.

In Pennsylvania and New Jersey the name of Red Birch is given to the Betula rubra, to distinguish it from the White Birch; but farther south, where the White Birch does not exist, or is comparatively rare, this species is simply called Birch,

The Red Birch is not, like the other species of this genus, seen growing in the midst of the forest, but is found only on the banks. of rivers, accompanied by the Buttonwood, the White Maple and the Willow. It expands. with the greatest luxuriance on the sides of limpid streams which have a gravelly bed, and whose banks are not marshy like those of the rivers in the maritime parts of the Carolina and of Georgia. On the Delaware, 30 miles from Pbiladelphia, along the 
rnad that leads to New York by New Hope and Sommerset, I have seen several Red Birches which were 70 feet in height, and 2 or 3 feet in diameter. They rarely exceed these dimensions in Virginia and North Carolina, where, from the milder temperature of the climate, they are more abundant.

On the trunk and on the largest limbs of a lofty Red Birch, the bark is thick, deeply furrowed, and of a greenish colour. On trees not exceeding $\delta$ or to inches in diameter, the epidermis is reddish or cinnamoncoloured, whence probably is derived the appropriate denomination of Red Birch. The epidermis of this species, like that of the Canoe Birch, divides itself transversally into thin, transparent sheets, which appear to be composed of a mixed substance, instead of presenting a pure, homogeneous texture; hence they have not an uniform transparency, nor a perfectly even surface : compared with the bark of the Canoe Birch, they are like coarse paper compared with fine. When this tree is fully expanded, its summit is ample, but the uncommon thickness of its branches prevents it from oppearing tufted. The twigs, which form the extremity of the tree, are long, flexible and pendulous, and the limbs are of a brown complexion spotted with white : their bark is slightly uneven, while, on the other branches, it is smooth and glossy.

The petioles of the Red Birch are short and downy; the leaves are about 3 inches long and 2 inches broad, 
of a light green on the upper surface and whitish beneath : they are doplybly denticulated at the edge, very acuminate at the summit and terminated at the hase in an acute angle mpre regular than is seen in the leat of any other tree. The fertile aments afe 5 or 6 inches long, straight, and nearly cylindrical. The seeds are ripe in the beginning of June.

The wood of the Red Birch is sufficiently compact and nearly white : very little difference in colour is observed between the sap and the heart. This wood offers the same singularity with that of the June Berry , being longitudinally marked by red vessels, which intersect each other in different directions. In some parts of Virginia and North Carolina, the negroes make bowls and trays of Red Birch, when they cannot procure Poplar. When saplings of Hickory or White Oak are not to be found, hoops, particularly those of rice casks, are made of the young stocks and of branches not exceeding an inch in diameter. In Philadelphia its twigs are exclusively chosen for the brooms with which the strets and court-yards are swept, which are similar to those employed for the same purpose in Paris. The twigs of the other species of Birch being less supple and more brittle, are not proper for this use.

Though the Red Birch is constantly found on the borders of rivers, it is not naturally confined to them : a flourishing stock, more than 30 feet in height, exists in the garden of the State-house at Philadelphia. Among 
all the Birches, the regetation of this species only is invigorated by intense heat : this consideration suffices to recommend its propagation in Italy, and in the southern parts of France and of the United States ; for it has been judiciously observed by authors who have written on this genus of trees, that if the good properties of the Birch are not brilliant, they are at least numerous and usefiul.

\section{PLATE LXXII.}

$A$ branch, with leaves and a barren ament of the natural size. Fig. I, A seed. Fig. $2, A$ scale. 



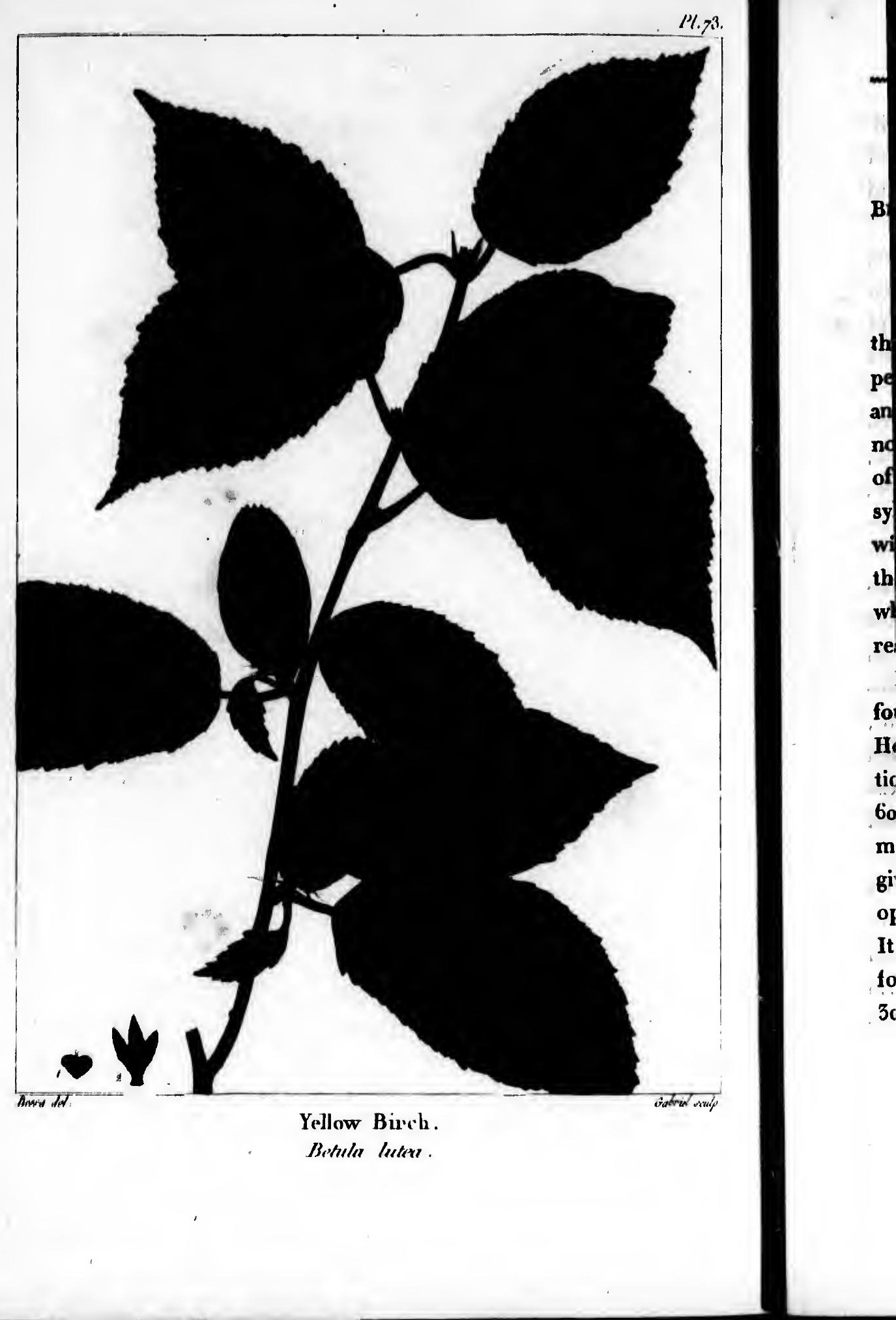




\section{YELLOW BIRCH.}

Betula zutra. B. folius ovatis, acutis, serratis; petiolis pubescentibus.

Tris species, like the Canoe Birch; belon only to the northern regions of the New World. It abounds especially in the forests of Nova Scotia, of New Brunswick, and of the District of Maine, where it is designated by no other name than Yellow Birch. On the western bank of the Hudson it is rare; and in New Jersey and Pennsylvania only a few individuals of the species are met with, in moist and shady situations. It is confounded by the inhabitants of these States with the Alack Birch, which is very abundant, and to which it bears a striking resemblance.

In the District of Maine the Yellow Birch is always found on cool and rich soils, among the Ashes, the Hemlock Spruce, and the Black Spruce. In these situations it exhibits its amplest dimensions, which are 6o or 70 feet in height, and more than 2 feet in diameter. The specific name of excelsa, which has been given to it, is injudicious, as it leads to an erroneous opinion that it surpasses every other species in height. It is a beautiful tree, and its trunk is of nearly an uniform diameter, straight, and destitute of branches for 30 or 40 feet. It is particularly remarkable for the colour 
and arrangement of its epidermis, which is of a briliant golden yellow, and which frequently divides itself into very fine strips, rolled backwards at the ends, and attached in the middlé.

The young shoots, and the leaves at their unfolding are downy; towards the middle of summer, when fully exphided, the leaves are perfectly smooth, except the petiole, which remains covered with a fine, short hair : they are about 3 inches and a half long, and 2 inches and a half broad, oval acuminate, and bordered with sharp and irregular teeth. The leaves, the bark, and the foung shoots have an agreeable taste and smell, similar to those of the Black Birch, though less seinsible, which they lose in drying.

In its fuctilication, this species nearly resembles the Black Birch. The fertile áments are borne on short peduncles, and are 12 or 15 lines long, 5 or 6 lines in diameter, straight, of an oval shape, and nearly cylindrical. The scales which compose them are trifid, pointed, and about 3 lines in length : viewed through the lens, they are seen to be downy. Beneath these scales are the small wioged seeds, which are ripe about the first of October.

The wood of the Yellow Birch is inferior in quality and in appearance to that of the Black Birch, and never assumes as deep a shade; but it is strong, and, when well polished, makes handsome furniture. In Nova Scotia, and in the District of Maine, it is found by expe-

rie of

Dist

and

you hoo

is

T

is a

Dist

in $t$

pro]

fair

that

por

high

Odd

si

I co

thes

Ger

thar

give

size. 
YELLOW UIACH.

rience to be every way proper for that part of the frame of vessels which remains always in the water. In the District of Maine it is preferred for the yokes of cattle and for the frames of sledges; and in Nova Scotia the young saplings are almost exclusively employed for the hoops of casks.

The Yellow Birch is an excellent combustible, and it is annually transported in great quantities from the District of Maine to Bostun. Its bark is highly esteemed in tanning; but in Maine it is employed in a very small proportion, and only for what is called by the curriers fair leather.

Oddy, in his Trentise on European Commerce, affirms that great quantities of Yellow Birch boards are imported into Scotland and Ireland, and that they are highly esteemed in joinery. The Birch mentioned by Oddy is doubtless the species which I am describing.

Such are the ubservations concerning this tree which I collected in my travels throngh the United States : they lead me to believe that the soil and climate of Germany would be more favourable to its multiplication than those of France, where the preference should be given to the Black Birch, which requires less humidity.

\section{PLATE LXXIII.}

A branch, with leaves and fertile aments of the natural size. Fig. 1, A seed. Fig. 2, The scale which covers the seed. 
$37^{2}$.

\section{BLACK BIRCH.}

Betula Lenta. B. foliis condatis-ovatis, argute serratis, acuminatis, glabris.

Betula carpinifolla. A. Micu. Blor. Dor. Am.

The agreeable foliage of this species, and the valuable properties of its wood, render it the most interesting of the American Birches. Wherever it grows in the United States, it is known by the name of Black Birch : its secondary denominations are Mountain Mahogany in Virginia, and Sweet Birch and Cherry Birch in Connecticut , Massachusets, and farther north. In Canada it is universally called Cherry Birch.

I have observed the Cherry Birch in Nova Scotia, in the District of Maine, and in the State of Vermont, though more rarely than the Yellow Birch. It abounds in the Middle States, particularly in New York, Pennsylvania and Maryland; farther south it is confined to the summit of the Alleghanies, on which it is found to their termination in Georgia, and to the steep and shady banks of the rivers which issue from these mountains. According to my own researches, it is a stranger to the lower part of Virginia, and to the southern and maritime parts of the Carolinas and of Gcorgia ; nor do I remember to have seen it in Kentucky, nor in the western part of Tennessee. 


$$
\text { 列 }
$$




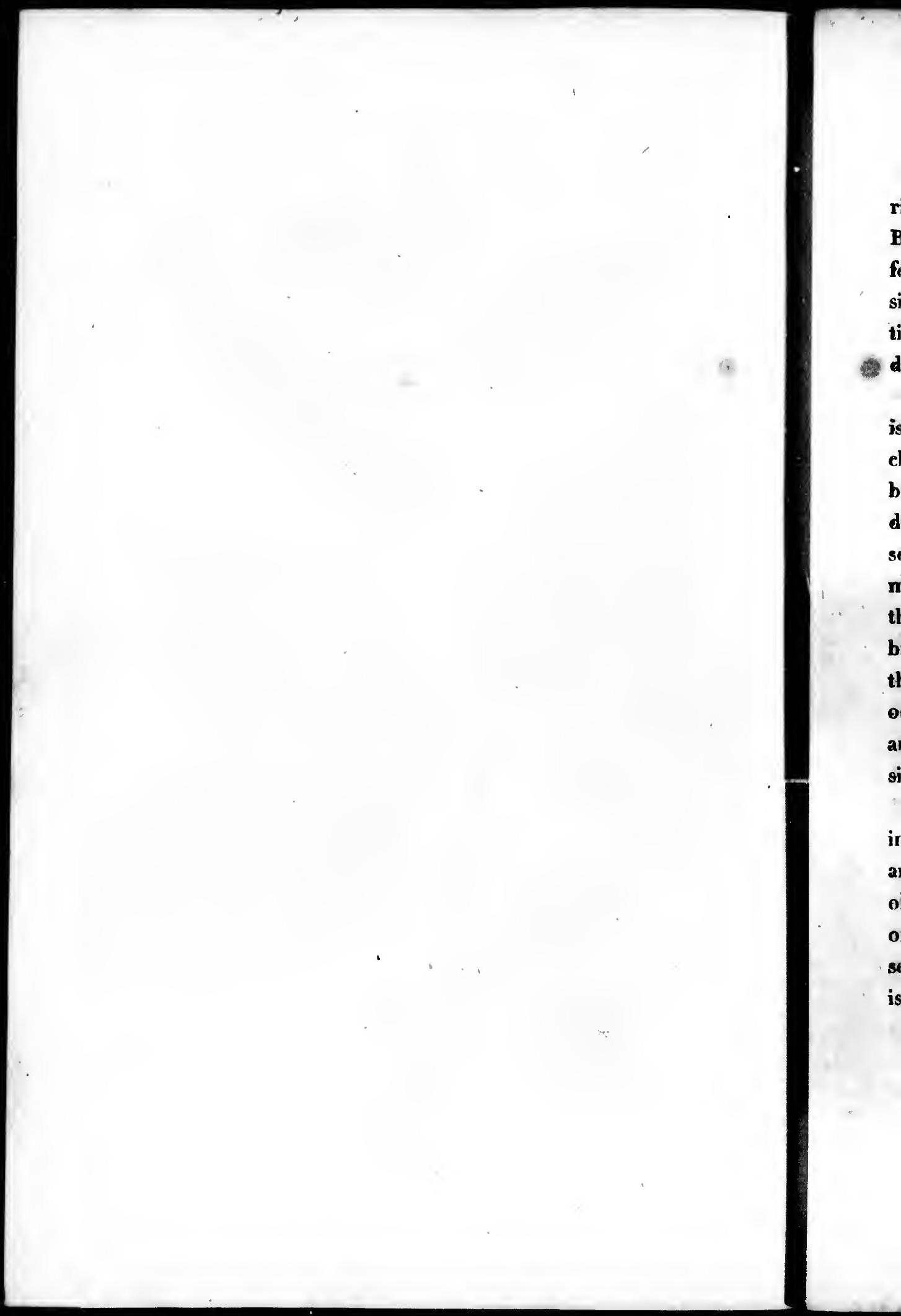


BLACE BIRCH.

In New Jersey, and upon the banks of the Nortt river, where I have most attentively observed the Black Birch, I have uniformly remarked that it grew of preference in deep, loose and cool soils, and that in these, situations it attained its greatest expansion, which some times exceeds 70 feet in height, and 2 or 3 feet in diameter:

In the neighbourhood of New York, the Black Birch is one of the earliest trees to renew its foliage. At the close of winter the leaves, during a fortnight after their birth, are covered with a thick, silvery down, which disappears sonn after. They are about 2 inches long, serrate, cordiform at the base, acuminate at the summit, of a pleasing tint and fine texture, and not unlike the leaves of the Cherry. Tree. The young shoots are brown, smooth, and dotted with white, as are also the leaves. When bruised the leaves diffuse a very sweet odour, and, as they retain this property when dried and carefully preserved, they ifford an agreeable infusion, with the addition of sugar and milk.

The barren flowers of the Black Birch are disposed" in flexible aments about 4 inches kong. The fertile aments, which are commonly siluated at the extremity of the young branches, are roor 12 lines long, and 5 or 6 lines in diameter, straight, cylindrical, and nearly sessile at the season of the maturity of the seed, which is about the first of November.

The bark, upon the irunk of trees less than 8 inches 
in diameter, is smooth, greyish, and perfectly similar in its colour and organisation to that of the Cherry Tree. On old trees, the epidermis detaches itself transversely, at intervals, in hard, ligneous plates, 6 or 8 inches broad.

The wood of the Black Birch, when freshly cut, is of a rosy hue, which deepens by exposure to the light. Its grain is tine and close, whence it is susceptible of a brilliant polish ; it possesses also a considerable share of strength. The union of these properties renders it superior to the other species of American Birch; and in Massachusets, Connecticut and New York, it is next in esteem to the Wild Cherry Tree, among cabinetmakers in the country. Tables and bedsteads of this wood, when carefully preserved, acquire with time the appearance of Mahogany, hence it is employed in Boston for the frames of arm-chairs and of sofas : the coach-makers also use it for the frames of their panels: Shoe-lasts are made of Black Birch, but they are less esteemed than those of Bee:h. Such are the principal uses of this wood, from which it may easily be gathered to what subsidiary purposes it is applicable.

The regetation of the Black Birch is beautiful and; in a congenial soil, its growth is rapid. A proof of this last assertion is found in the Annals of the Arts, where a stock of this species is reported to have attained the height of $\mathbf{4 5}$ feet and 8 inches in 19 is.

These considerations should induce the Americans to 
BLACK BIRCH.

375

nilar Cree. sely, ches is of Its of a re of sud in next inetthis

Abranch, with leapes and fertile aments of the natural sire. Fig. 1, A seed. Fig. $2, A$ scale which covers the seed. nd;
this
pere
the nd;
this
here
the nd;
this
here
the nd;
this
here
the bestow great care on the preservation of the Black Bircb, and the inhabitants of the Old World to introduce it into their forests. The attempt upon a great scale would be more successful in the north of France, in England and in Germany, on account of the greater humidity of the climate, than in more southern countries.

I shall terminate this description of one of my favourite trees, by recommending it to the lovers of foreign vegetables, as eminently adapted, by the beauty of its foliage and by the agreeable odour of its flowers, to figure in their parks and gardens.

\section{PLATE IXXIV.}

$d$ in the nels: less ipal ered is to 
376

\section{ALDERS.}

\section{GOMMON ALDER.}

Alnus sennumata. A. stipulis ovalibus, obtusis; foliis. duplicato-serratis, ovalibis, acutis.

THis species ' of Alder' is found in the Northern; Middle, and Western States, and is every where designated by the name of Common Alder. It frequently grows along the sides of brooks, and abounds still more in places covered with stagnant water. Its ordinary size is 8 or 10 feet in height, and about 2 inches in diameter, though often it is less. Its leaves are of a beautiful green, about 2 inches long, oval, distinctly sulcated on the surface, and doubly denticulated at the edge.

This shrub blooms in January : the sexes are separate upon the same stock. The barren flowers are disposed, like those of the Birch, around a common axis, in flexible pendulous aments ahout 2 inches long. The fertile flowers are in the form of small, oval bodies, garnished with a dull, red fringe : they are converted into small, scaly cones, which open, wher arrived at maturity, to release the minute, flat seeds.

The wood of the Common Alder, when first laid open, is white, and it becomes reddish by contact with 


$$
\text { : }
$$




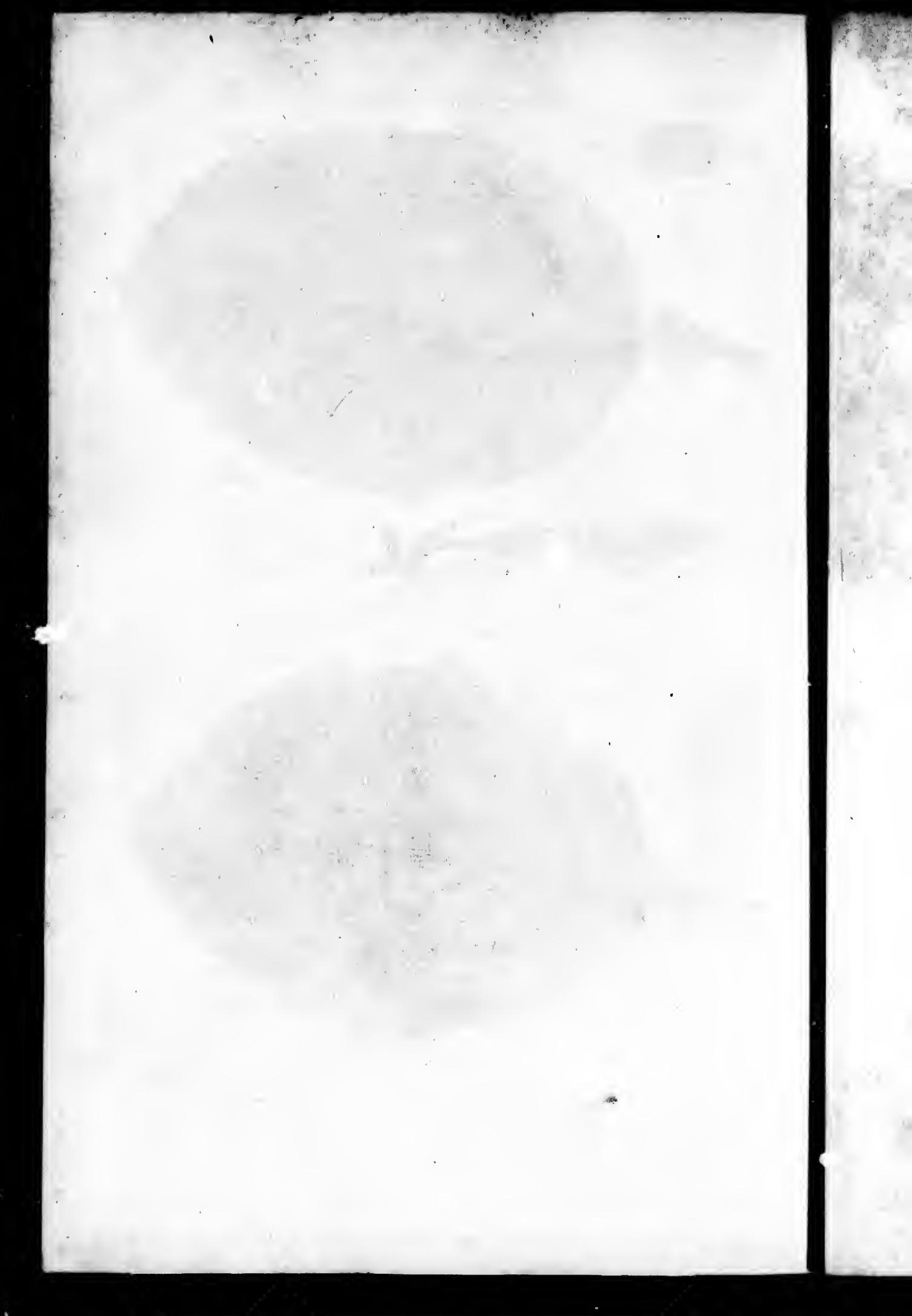


COMMON ALDER.

377

the air : its resemblance in this respect to the analogous European species, Aline ghutinosa, leads me to believe that they are alike also in the properties of their bark.

The Common Alder is too small to be applicable to any use in the arts : from its inferiority of size, it will probably one day give place to the European Alder.

PLATE LXX:

Common Alder, with a leaf of the natural size. Fig. 1, $A$ fertile and a barren ament. Fig. 2, A cone at maturity. Fig: 3 , Seeds.

8 


\section{BLACK ALDER.}

Atsue gravca. A. foltis subrotundoellipticis, duplicaidserratis, subbus glaucis.

Alnus incana: WiLlo.

This species of Alder, which is unknown in the Southern, and rare in the Middle States, is not uncommon in Massachusets, New Hampshire and Vermont; but even here it is less multiplied than the Commion 'Alder, which abounds throughout the United States. The Black Alder is a third taller than the preceding species, being sometimes 18 or 20 feet in height, and about 3 inches in diameter. Its leaves are similar ir shape, but are easily distinguishable by their different tint and superior size : they are of a pale bluish green, and a third larger than those of the Common Alder. Both species grow in cool, moist places, and upon the margin of rivulets.

The bark of the trunk and of the secondary branches is smooth, glossy, and of a deep brown colour sprinkled with white. It is employed by hatters, if I have been correctly informed, for dying black. The diminutive size of this tree excludes it entirely from nse ; but to recommend it to the notice of Amateurs it is only necessary to observe that it is one of the most beautiful species of the genus. 
BLACK ALDER:

379

The dwarfish stature of all the species of Alder that have hitherto been discovered in North America, exclues them from that class of vegetables to the deecription of which I have restricted my labours; but I could not forbear mentioning the two most remarkable species, of which one merits attention on account of its abundant diffusion, and the other on account of a striking peculiarity in the colour of its leaves:

PLATE LXXVI.

Black Alder, with a leaf of the natural size.

49 


\section{COMMON EUROPEAN ALDER.}

Alwus grutinosa. A. foliis subrotundo-cuneatis, oblusis, subretusis, glutinosis; axillis venarum subtius villosis.

The Common European Alder bears so great a resemblance to the Common American Alder, in its flowers, its seeds, its leaves, its wood and its bark, as to render a scparate figure unnecessary : the only difference observable between them is that the European species is larger and has smaller leaves.

The Common European Alder is a tine tree of more than 50 feet in height : its trunk is generally straight, and tapers gradually from the base to the summit, and it is garnished with numerous branches, tending rather to close round the stock, than to diffuse themselves widely : hence the Alder, like the Lombardy Poplar, grows in great numbers in. a small space, without impediment from the proximity of the stocks.

The wood of this tree is fine-grained, compact, susceptible of a fine polish, and not destitute of strength. When perfectly dry, it is light and easily wrought; hence it is in request with manufacturers of wooden ware. In France immense quantitics of wooden slones are made of it, which are seasoned by fire before they are sold. The Alder takes a better black than any other wood, 
and when polished and varnished it affords a good imitation of Ebony. With sulphat of iron the bark forms a black die for colouring wool, and, as it is procured at a very low price, it is extensively substituted for gall nuts by halters and diers. The wood of the Alder, when deeply buried in earth that is constantly humid, is found to endure a great length of time; it is therefore used for the pipes of conduits. In Flanders and IIolland it serves for the piles upon which buildings are erected in marshy places.

In France, England and Germany, the Alder is considered as a valuable trec, on account of its rapid growth in wet grounds. It is frequently observed on the sides of streams flowing through meadows, and, as its roots penetrate to a great distance, it contributes more effectually than most olher trees to support the banks at the season of the overflowing of the waters.

The European Alder shoots wilh such vigour, that copses formed of it may be cut every seven years, and at the end of 18 years they furnish trees exceeding 35 feet in height, whose wood is far superior to that of the Lombardy Poplar. It is obtained from the seed, or from cuttings of $a$ proper lengt $h$, buried in very moist ground, except a few inches that appear above the surface. The young plants should be cut the second year, to invigorate their roots. The seeds of the Alder are very small, and are in danger of perishing if they are not very lightly covered with earth. 
This tree, to which so much importance is attached in Europe will probably at a future period be considered as a valuable acquisition in America, especialiy in the States east of the river Hudson. 


\section{T A B LE.}

Introduction.. . . . . . . . . Page j

The Oak. . . . . . . . . . . . . . . . I

Methodical disposition. . . . . . . . . . 9

White Oak. . . . . . . Quercus alba. . . . . . . Is

Common European Oak. . Q Quercus robur. . . . . 28

European White Oak. . ." Quercus pedunculata. . . 3o

Mossy Cup Oak . . . . . Quercus olivaformis. . . . 33

Over Cup White Ouk . . . Q Quercus macrocarpa. . . 35

Post Oak. . . . . . . . Q Quercus oblusiloba. . . . 37

Over Cup Oak . . . . . Quercus lyrata. . . . . 43

Swamp White Oak. . . . Quercus prinus discolor. . 47

Chesnut White Oak. . . . Q Quercus prinus palustris. . 52

Rock Chesnut Onk.. . . . Q Quercus prinus monticola. 56

Yellow Oak . . . . . . Quercus prinus acuminata. 6x

Small Chesnut Oak.. . . . Q Quercus prinus Chincapin. 64

Live Oak. . . . . . . . Quercus virens. . . . . 67

Cork Oak . . . . . . . Quercus suber. . . . . $7^{3}$

Willow Oak . . . . . . Quercus phallos. . . . . 78

Laurel Oak . . . . . . Quercus imbricaria. . . 82

Upland Willow Oak . . . Quercus cinerea. . . . 85

Running Oak . . . . . Quercus pumila. . . . 88

Bartram Oak. . . . . . . Qucrcus heterophilla. . : 90

Water Oak. .. . . . . . Quercus aquatica. . . . 92

Black Jack Oak. . . . . . Quercus ferruginea. . . 95

Bear Oak . . . . . . . Quercus banisteri. . . . 99

Barrens Scrub Oak . . . Q Quercus catesbrei. . . . 103

Spanish Oak . . . . . . Q Quercusfalcatu. . . . . 106

Black Oak. . . . . . . . Quercus tinctoria. . . . II I

Scarlet Oak. . . . . . . . Qucrcus coccinea. . . . I 16

Grey Oak. . . . . . . . . . Quercus borcalis. . . . . 119

Pin Oak." . . . . . . . Q Qucrcus palustris. . . . ". 122

Red Oak. . . . . . . . Quercus rubra. . . . . 125

Additions to the Oaks. . . . . . . . . . . 228 
Walnuts. . . . . . . . . . . . . . . . Page 137

Common European Walnut. Juglans regia. . . . . . 1/3

Black Walnut. . . . . . . Juglans nigru. . . . . . 153

Butternut. . . . . . . . Juglans calhartica. . . . 160

Pacanenut Hickory. . . . . J Juglans olivaformis . . . 167

Bitternut Hickory. . . . . Juglans amara. . . . . 170

Water Bitlernut Hickory. . . Juglans aquatica. . . . . 174

Mockernut Hickory.. . . . . Juglans tomentosa. . . . 176

Shrllbark Hickory . . . . . . Juglans squamosa. . . . I8t

Thick shellbark Hickory. . . J Juglans laciniosa. . . . . I88

Pignut Hickory. . . . . . . Juglans porcina. . . . . 1!)4

Nutmeg Hickory . . . . . . J Juglans myristicaformis. . 198

Recapitulation ................. 200

Maples. . . . . . . . . . . . . . . . 208

Whiie Maple. . . . . . . Acer eriocarpum. . . . . 213

Red flowering Maple . . . . Acer rubrum. . . . . . . 217

Sugar Maple. . . . . . . . . Acer succharinum . . . . 223

Black Sugar Maple. . . . . A Accr nigrum. . . . . . 237

Norway Maple . . . . . . Acer plalanoïdes. . . . 2/40

Sycamore . . . . . . . . Acer pseudo-platanus. . 242

Moose wood . . . . . . A Acer striatum. . . . . 2/45

Box elder.. . . . . . . . Acernegundo. . . . . . 249

Mountain Maple . . . . . . Acer montanum. . . . . 253

Dogwood. . . . . . . . Cornus florida . . . . . 255

Georgia bark. . . . . . . . Pinckneya pubens. . . . 260

Coffee iree . . . . . . . Gymnocladus canadensis. . 263

Magnolias. . . . . . . . . . . . . . . . 2677

Big Laurelt . . . . . . . . Magnolia grandiffora . . . 269

Small Magnolia or white bay. Magnolia glauca. . . . 274

Cucumber Tree ... . . . Magnolia acuminala. . . 278

Heart-Leaved Cucumber Tree. Magnolia cordala . . . . 282

Umbrella tree . . . . . . . Magnolia iripeiala. . . . 284

Long-Leaved Cucumber Tree. Magnolia auriculata. . . 287

Large-Leaved Umbrella Tree. Magnolia macrophylla. . . 291

Loblolly bay. . . . . . . . Gordonia lasyanthus. . . 295

Franklinia. . . . . . . Gordonia pubescens. . . . 298 
Papaw . . . . . . . . Anona triloba . . . . . 30o

Poplar, or Tulip Tree. . . . Lyriodendrum tulipifera. . 3o3

Sweet Gum. . . . . . . . . Liquidambar styraciflua. . 315

Butlonwood, or Sycamore. . Platanus occidentalis. . . . 32r

Catalpa. . . . . . . . . Bignonio cataipa . . . . 329

Crab Apple . . . . . . Malus coronaria . . . . 333

June Berry . . . . . . . . Mespilus arborea. . . . . 336

Dwarf Rose Bay . . . . . . Rhododendrum maximum. 339

Moutain Laurel. . . . . . Kalmia latifolia.. . . . . 342

Birches. . . . . . . . . . . . . . . . . . 347

Canoe Birch . . . . . . . Betula papyrifera .... 35r

Common European Birch. . . Betula alba ... . . . 356

White Birch. . . . . . B Betula populifolia . . . . 363

Red Bich. . . . . . . . . Betula rubra . . . . . . 365

Yellow Birch. . . . . . . Betula lutea. . . . . . 36g

Black Birch . . . . . . . Betula lenta. . . . . . . 372

Alders.-Common Alder . . A Alder serrulata. . . . . 376

Black Alder. . . . . . . . Alnus glauca. . . . . . 378

Common European Alder. . . Alnus glutinosa. . . . . . 380

END OF THE FIRST VOLUME. 
,

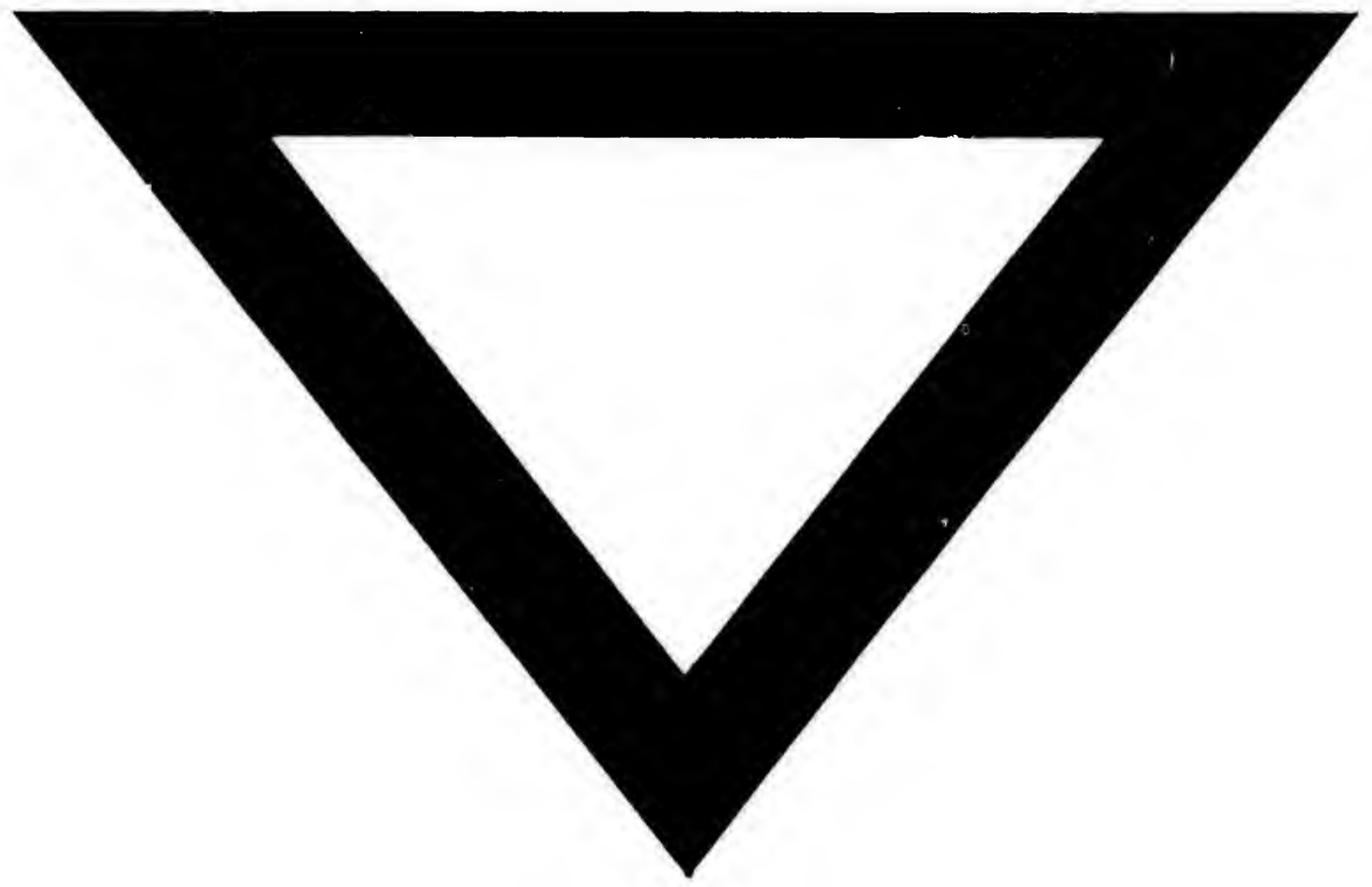

